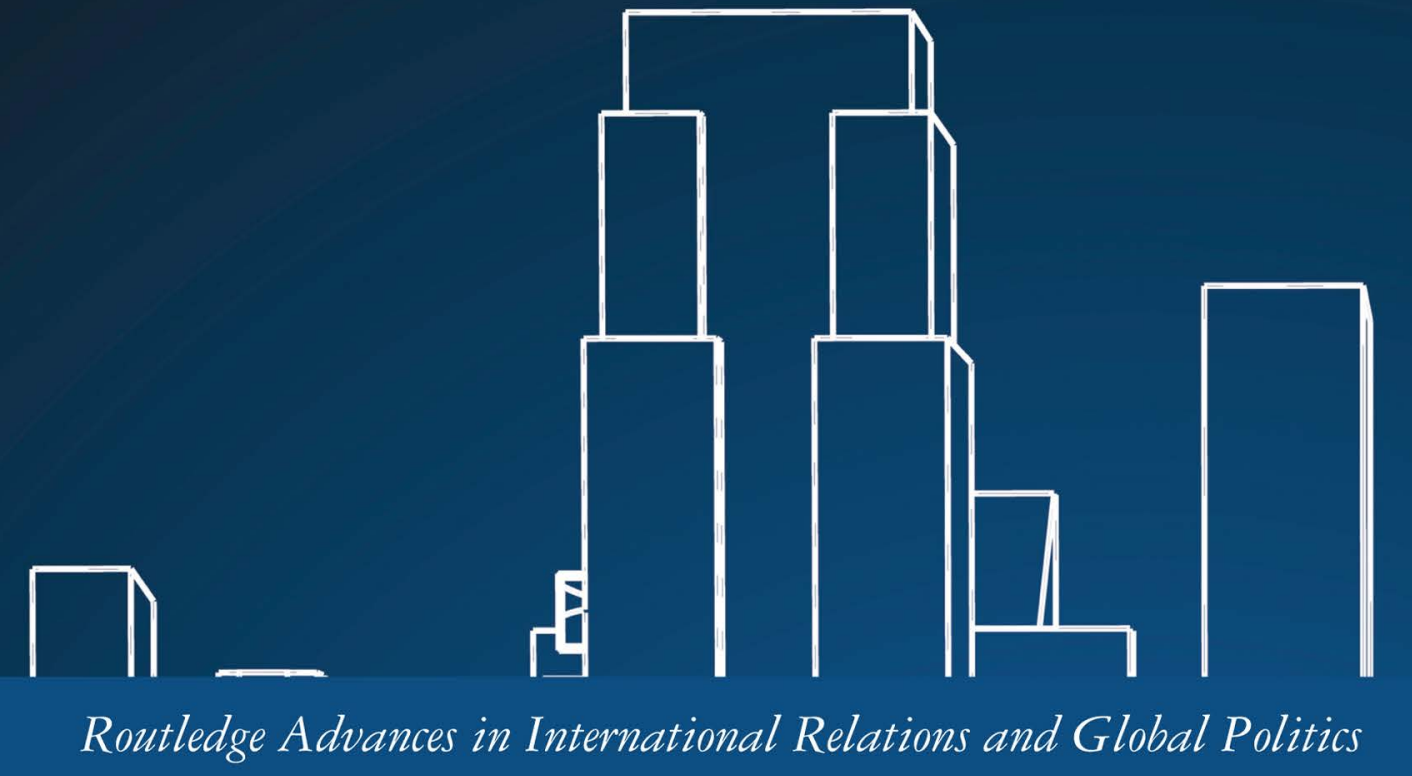

\title{
ECONOMIC SANCTIONS IN INTERNATIONAL LAW AND PRACTICE
}

Edited by

Masahiko Asada

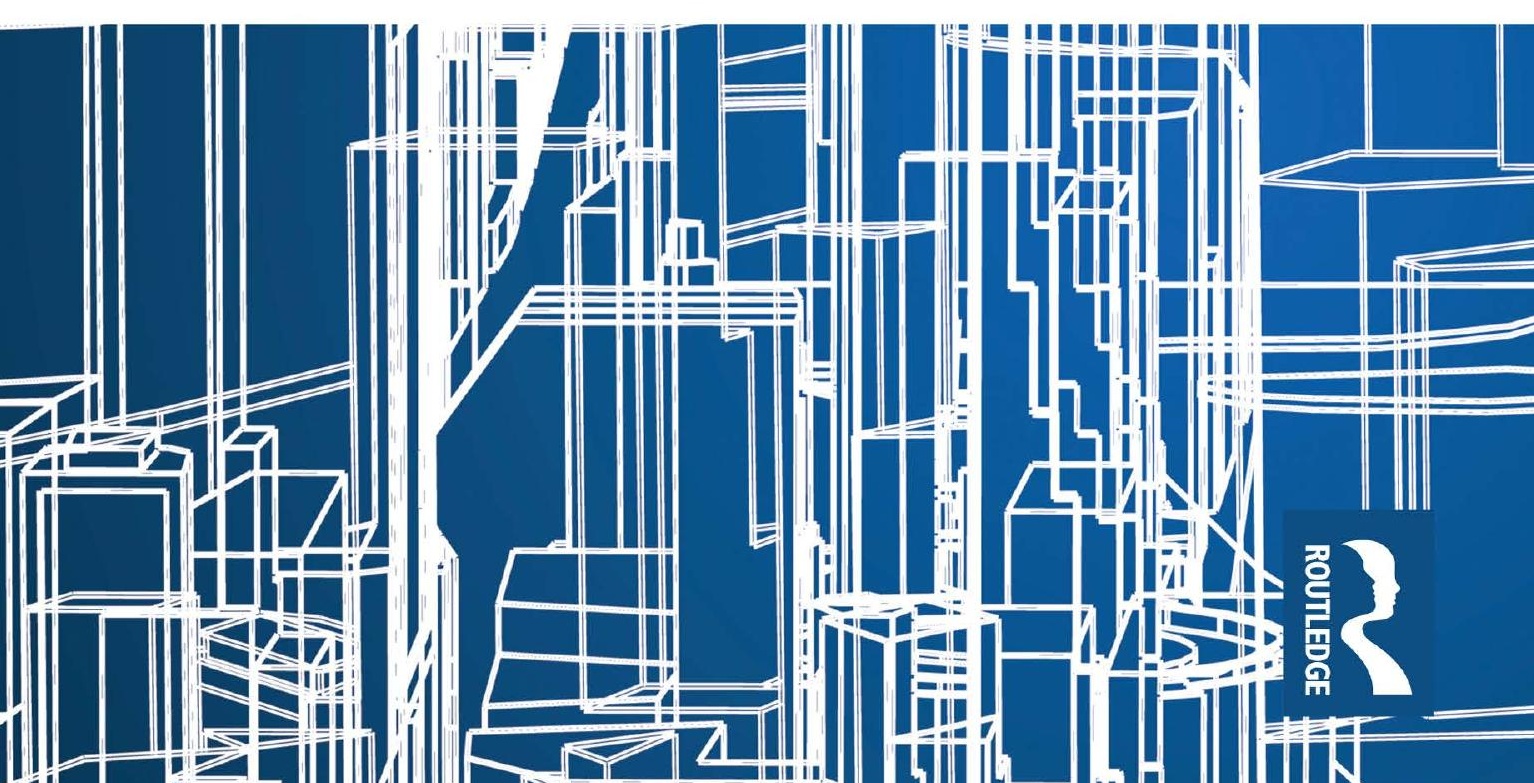




\section{Economic Sanctions in International Law and Practice}

Providing perspectives from a range of experts, including international lawyers, political scientists, and practitioners, this book assesses current theory and practice of economic sanctions, discussing current legal and political challenges faced by the international community.

It examines both the implementation of sanctions by major powers - the United States, the European Union, and Japan - as well as assessing the impact of those sanctions through case studies of Russia, Iran, Syria, and North Korea. Balancing theoretical analysis of legal considerations with national and regional level empirical analysis, it also includes coverage of sanctions issues by the UN Security Council and the EU, as well as the extraterritorial application of sanctions.

A valuable reference for academics and practitioners, Economic Sanctions in International Law and Practice will be useful to those working in the fields of international law, diplomacy, and international political economy.

Masahiko Asada is Professor of International Law at the Graduate School of Law, Kyoto University, Japan, and President of the Japanese Society of International Law. 


\section{Routledge Advances in International Relations and Global Politics}

139 Joining the Non-Proliferation Treaty

Deterrence, Non-Proliferation and the American Alliance

Edited by John Baylis and Yoko Iwama

140 New Geographies of Global Policy-Making

South-South Networks and Rural Development Strategies

Carolina Milhorance

141 Norm Dilemmas in Humanitarian Intervention

How Bosnia Changed NATO

Yuki Abe

142 American Hegemony in the 21st Century

A Neo Neo-Gramscian Perspective

Jonathan Pass

143 The Duty of Care in International Relations

Protecting Citizens Beyond the Border

Nina Graegar and Halvard Leira

144 The Global Politics of Jazz in the Twentieth Century

Cultural Diplomacy and "American Music"

Yoshiomi Saito

145 South Africa and the UN Human Rights Council

The Fate of the Liberal Order

Eduard Jordaan

146 Economic Sanctions in International Law and Practice Edited by Masahiko Asada

For information about the series: www.routledge.com/Routledge-Advancesin-International-Relations-and-Global-Politics/book-series/IRGP 


\section{Economic Sanctions in International Law and Practice}

Edited by Masahiko Asada

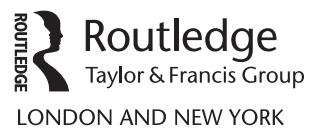


First published 2020

by Routledge

2 Park Square, Milton Park, Abingdon, Oxon OX14 4RN

and by Routledge

52 Vanderbilt Avenue, New York, NY 10017

Routledge is an imprint of the Taylor \& Francis Group, an informa business

(C) 2020 selection and editorial matter, Masahiko Asada; individual

chapters, the contributors

The right of Masahiko Asada to be identified as the author of the editorial material, and of the authors for their individual chapters, has been asserted in accordance with sections 77 and 78 of the Copyright, Designs and Patents Act 1988.

All rights reserved. No part of this book may be reprinted or reproduced or utilised in any form or by any electronic, mechanical, or other means, now known or hereafter invented, including photocopying and recording, or in any information storage or retrieval system, without permission in writing from the publishers.

Trademark notice: Product or corporate names may be trademarks or registered trademarks, and are used only for identification and explanation without intent to infringe.

British Library Cataloguing-in-Publication Data

A catalogue record for this book is available from the British Library

Library of Congress Cataloging-in-Publication Data

Names: Asada, Masahiko, 1958- editor.

Title: Economic sanctions in international law and practice / edited by Masahiko Asada.

Identifiers: LCCN 2019028891 | ISBN 9780367146610 (hardback) | ISBN 9780429052989 (ebook) | ISBN 9780429629655 (adobe pdf) | ISBN 9780429626371 (mobi) | ISBN 9780429628016 (epub)

Subjects: LCSH: Sanctions (International law) - Congresses.

Classification: LCC KZ6373 .E265 2020 | DDC 341.5/82 - dc23

LC record available at https://lccn.loc.gov/2019028891

ISBN: 978-0-367-14661-0 (hbk)

ISBN: 978-0-429-05298-9 (ebk)

Typeset in Times New Roman

by Apex CoVantage, LLC 


\section{Contents}

List of tables vii

Notes on the contributors viii

Preface xii

PART I

Legal considerations

1 Definition and legal justification of sanctions 3

MASAHIKO ASADA

2 United Nations and sanctions 24

PHILIPPE ACHILLEAS

3 Human rights implications of sanctions $\quad 39$

PIERRE-EMMANUEL DUPONT

$4 \quad$ Legality of extraterritorial sanctions $\quad 62$

MIRKO SOSSAI

\section{PART II}

Implementation of sanctions

$5 \quad$ History of implementation of sanctions 83 JEAN-MARC THOUVENIN

6 Implementation of sanctions: United States 
vi Contents

7 Implementation of sanctions: European Union 116 FRANCESCO GIUMELLI

8 Implementation of sanctions: Japan 136 MACHIKO KANETAKE

PART III

Case studies

9 North Korea: Design, implementation, and evasion 157 ANDREA BERGER

10 Iran: The role and effectiveness of UN sanctions 178 KAZUTO SUZUKI

11 Syria: The chemical weapons question and autonomous sanctions

TATSUYA ABE

12 Russia: The Crimea question and autonomous sanctions MIKA HAYASHI

Index 


\section{Tables}

7.1 EU restrictive measures divided per type of crisis since 1993

10.1 Settlements paid to the US Treasury 186

11.1 List of United States Executive Orders related to the Syrian sanctions program 201

11.2 List of United States Executive Orders related to the sanctions against proliferators of weapons of mass destruction 202

11.3 List of designated individuals (U.N. Doc. S/2017/172
(February 28, 2017), Annex 1)

11.4 List of designated entities (U.N. Doc. S/2017/172 (February 28, 2017), Annex 1) 206

11.5 Chronology of designations from June 2005 to July 2013

11.6 Chronology of designations from August 2013 to July 2016

11.7 Chronology of designations from August 2016 to August 2017 


\section{Notes on the contributors}

Tatsuya Abe is Professor of International Law at the School of International Politics, Economics and Communication, Aoyama Gakuin University, Japan. He has been deeply involved in the Organization for the Prohibition of Chemical Weapons (OPCW) in various capacities, serving as an alternate of the Permanent Representation of Japan, a member of the Confidentiality Commission, a member of the Advisory Board on Education and Outreach, and staff of the Technical Secretariat. His recent articles include "Challenge Inspections Under the Chemical Weapons Convention: Between Ideal and Reality," The Nonproliferation Review, Vol. 24 (2017); "Effectiveness of the Institutional Approach to an Alleged Violation of International Law: The Case of Syrian Chemical Weapons," Japanese Yearbook of International Law, Vol. 57 (2014).

Philippe Achilleas is Professor of Public Law at the University Paris Sud/Paris Saclay. He is the director of the Institute of Space and Telecommunications Law (IDEST), the master's degree in Law of Space Activities and Telecommunications, and the International Chair of Space and Telecommunications Law. Philippe Achilleas is also the director of the scientific consortium established between the University Paris Saclay and the French Space Agency. Achilleas has taught various subjects, including space and telecommunications law as well as international and European law at numerous universities in France and in other countries. Achilleas is the author of numerous publications in various subjects related to international and European law, space law and space policy, and communications law and policy. He is also a consultant for space companies, spaces agencies, telecom operators, and regulators. Achilleas is a member of the French delegation to UNCOPUOS. He works in collaboration with the European Space Agency, the International Telecommunication Union, and the International Organization of the Francophonie.

Masahiko Asada is Professor of International Law at the Graduate School of Law, Kyoto University, Japan, President of the Japanese Society of International Law, and a former president of the Japan Association of International Security and Trade. Professor Asada served as a member of the Panel of Experts established pursuant to Security Council Resolution 1874 (2009), North Korea Sanctions Panel, from 2009-2010. He also was a member of the UN Group 
of Governmental Experts on Verification from 2006-2007. A former Senior Associate at St. Antony's College, Oxford, Professor Asada worked as legal advisor to the Japanese Delegation to the Conference on Disarmament from 1991-1993. His recent publications include Post-War Reparations Between Japan and China under International Law (2015, in Japanese) as well as articles in American Journal of International Law, Harvard International Review, International Community Law Review, Journal of Conflict and Security Law, Italian Yearbook of International Law, Japanese Yearbook of International Law, and Taiwanese Yearbook of International Law.

Andrea Berger is Associate Fellow at the Royal United Services Institute for Defence and Security Studies (RUSI) in London, focusing on nonproliferation, illicit finance, and Northeast Asian security. She was previously a senior research associate at the Middlebury Institute for International Studies and an associate at King's College London. Prior to joining the Middlebury Institute, Ms. Berger was the deputy director of the nuclear policy team at RUSI and the co-head of the institute's sanctions program. Over the last five years she has worked with over a dozen countries to help craft their approaches to DPRK sanctions implementation. Ms. Berger is the author of Target Markets: North Korea's Military Customers in the Sanctions Era, and she has published numerous articles in journals including Survival, The RUSI Journal, and Arms Control Today.

Pierre-Emmanuel Dupont is a lawyer and a consultant in public international law and has advised several governments as well as public and private entities and corporations on a range of matters, including: boundary delimitation, dispute settlement procedures before international courts and tribunals, the law of the sea, the law of treaties, the responsibility of states and international organizations, international economic sanctions (UN, US, EU), state immunity, international humanitarian law, human rights law, and disarmament and nonproliferation issues. He is Senior Lecturer at the Free Faculty of Law, Economics and Management of Paris, where he teaches public international law and international arbitration, and Visiting Fellow at the International Maritime Law Institute of the IMO.

Francesco Giumelli is Associate Professor in the Department of International Relations and International Organization at the University of Groningen. He was previously Jean Monnet Fellow at the European University Institute and Fellow at the Kroc Institute of Notre Dame University. He is author of The Success of Sanctions: Lessons Learned from the EU Experience (2013) and Coercing, Constraining and Signalling: Explaining UN and EU Sanctions After the Cold War (2011). He published on sanctions, private military, and security companies in the Journal of Common Market Studies, International Affairs and International Peacekeeping.

Mika Hayashi is Professor of International Law at the Graduate School of International Cooperation Studies, Kobe University, Japan. She worked as a 
diplomat in the Japanese Ministry of Foreign Affairs from 1993-1997 before joining Kobe University, and she is a former visiting scholar at Wolfson College, Cambridge. Her articles on questions of international security and international law appear in journals such as Journal of Conflict and Security Law, Journal on the Use of Force and International Law, International Community Law Review, Journal of International Humanitarian Legal Studies, and Chinese Journal of International Law.

Machiko Kanetake is Assistant Professor of Public International Law at the School of Law, Utrecht University, the Netherlands. Dr. Kanetake received her Ph.D. from Kyoto University and L.L.M. at the London School of Economics (LSE). She has been appointed as a postdoctoral researcher and lecturer at the University of Amsterdam (2011-2014). She has also been appointed as a Hauser Visiting Doctoral Researcher (2010-2011) of the Global Fellows Program at New York University (NYU) School of Law, a visiting researcher (2012) of the University of Sydney, a visiting fellow (2014-2015) at the Human Rights Program, Harvard Law School, and a visiting fellow (2015) at the Transnational Law Institute, the Dickson Poon School of Law, King's College London. She serves as an editorial board member of the Leiden Journal of International Law.

Richard Nephew is Senior Research Scholar at Columbia University's Center on Global Energy Policy. He is the author of The Art of Sanctions. Prior to this, he was Principal Deputy Coordinator for Sanctions Policy at the Department of State from 2013-2015. During this time, he also served as the lead sanctions expert for the US team negotiating with Iran. From 2011 to 2013, Nephew served as Director for Iran at the National Security Council. He also served in other positions in nonproliferation at the Departments of State and Energy from 2003-2011. Nephew holds a master's degree in Security Policy Studies and a bachelor's degree in International Affairs, both from The George Washington University.

Mirko Sossai (Ph.D. Siena) is Associate Professor of International Law at the Law Department of the Roma Tre University, Italy. He is co-rapporteur of the ILA study group on UN sanctions and international law. He is a member of the editorial board of the Journal of Conflict and Security Law. His publications include a book on the prevention of terrorism in international law (in Italian), an edited volume (with Christine Bakker) on Multilevel Regulation of Military and Security Contractors: The Interplay Between International, European and Domestic Norms, and articles in Journal of Conflict and Security Law, Journal of International Criminal Justice, International Community Law Review, and Italian Yearbook of International Law.

Kazuto Suzuki is Vice Dean and Professor of International Politics at Public Policy School of Hokkaido University, Japan. He graduated from the Department of International Relations, Ritsumeikan University, and received his Ph.D. from Sussex European Institute, University of Sussex, England. He has 
worked in the Fondation pour la recherche strategique in Paris, France, as assistant researcher and as an associate professor at the University of Tsukuba from 2000 to 2008 before moving to Hokkaido University. He served as an expert on the Panel of Experts for Iranian Sanction Committee under the United Nations Security Council from 2013 to July 2015. He has been President of the Japan Association of International Security and Trade. His recent work includes Space and International Politics (2011, in Japanese, awarded Suntory Prize for Social Sciences and Humanities), Policy Logics and Institutions of European Space Collaboration (2003), and many others.

Jean-Marc Thouvenin is Professor of International Law at the Paris-Nanterre University, France. He held the positions of Secretary-General of the French Society for International Law (2001-2006), Directeur of the Center of Research on International Law in his University (2008-2016), and, since 2017, SecretaryGeneral of The Hague Academy of International Law. He has appeared as counsel and advocate before the International Court of Justice, the Permanent Court of Arbitration, and the International Tribunal of the Law of the Sea. He has also acted as counsel and advocate in sanctions cases before the European Court of Justice. His publications include a treatise on the international law of the sea and a sum on international social law. 


\section{Preface}

This book is a collection of chapters discussing current legal and political challenges that the international community has faced in instituting and implementing economic sanctions. Economic sanctions are one of the most powerful tools that the Charter of the United Nations allows the international community to resort to in order to promote or maintain a common value in the interest of the world. They have increasingly and frequently been used in the real world since around the end of the last century, particularly during the last decade. It is the right time and advisable to disseminate the recent development of the theory and practice of economic sanctions.

The book has its origin in a series of small symposiums held in 2015 to 2017 in Japan and in France. Three universities - Kobe University, Kyoto University, and the University of Paris Sud-11 - were the cosponsors of the symposiums, and Professors Philippe Achilleas at Paris, Dai Tamada at Kobe, and me at Kyoto were the co-organizers, so to speak. We created a Japanese-French study group called the International Group of Experts on Export Regulations (INGEER) and convened an annual symposium in Japan and France in turn. In dealing with export control issues, some participants, including myself, took up the question of UN and non-UN sanctions as an emerging and current major agenda. Considering its importance to contemporary international law and relations, I decided to compile a structured volume by adding some other suitable chapters of relevance.

The book's unique feature is that its contributors include a number of researchers who have an extensive experience in actual practice in sanction-related fields. They should properly be called researcher-practitioners. Two of the contributors have worked as members of the Panels of Experts for the UN Sanctions Committees (one for the DPRK sanctions and the other for the Iran sanctions) and advised and recommended to the Security Council concerning the formation and implementation of economic sanctions.

Another two of the contributors have the experience in working with international organizations in sanctions-related fields. One has assisted the UN Special Rapporteur on unilateral coercive measures (at OHCHR) as a legal adviser and is, at the same time, advising a number of governments and financial institutions in relation to economic sanctions. The other has worked as a senior planning officer at the Organization for the Prohibition of Chemical Weapons (OPCW), where the Syrian chemical weapons issue has been dealt with in collaboration with the United Nations. 
Still another two have been deeply involved in the policy planning of economic sanctions at the national level. One worked at the US Department of State as Principal Deputy Coordinator of the Office of the Coordinator for Sanctions, responsible for the development and implementation of all US sanctions programs and serving as the lead sanctions negotiator with Iran in the talks ultimately leading to the Joint Comprehensive Plan of Action (JCPOA) of 2015. The other has been advising various governments by providing detailed research and analysis on evasive tactics employed by sanctions targets and also advising financial institutions by providing training on sanctions implementation.

Considering these abundant varieties of contributors with extremely rich experiences, I decided to organize the book in three parts: theoretical, national (regional) implementation, and case studies. Part I is focused on generic legal considerations. Chapter 1 (Masahiko Asada) discusses the definition and legal justifications of economic sanctions. As exemplified by the ICJ suit recently brought by Iran against the United States, economic sanctions may possibly "violate" rules of international law applicable to their authors and targets. The chapter examines how the authors can legally justify their per se illegal sanctions. Chapter 2 (Philippe Achilleas) deals with the sanctions practice by the UN Security Council. After describing a variety of UN sanction measures, it addresses the challenges the Security Council has faced, including the humanitarian consequences some of the UN sanctions have caused as well as other human rights issues that have been brought about by smart sanction regimes. Chapter 3 (Pierre-Emmanuel Dupont) takes up human rights issues in a comprehensive manner. The chapter, acknowledging the UN efforts toward the principled recognition of the applicability of human rights standards to economic sanction regimes, describes and evaluates the measures created to safeguard human rights when implementing sanctions. Chapter 4 (Mirko Sossai) discusses the difficult question of legality of extraterritorial application of sanctions. Unlike UN sanctions, the imposition of autonomous sanctions may cause legal problems not only between the author and the target States but also between the author and third States. Controversy has centered on the legality of secondary sanctions applied by the United States on entities in other counties that have transactions with the entities under primary sanctions.

Part II deals with the implementation of sanctions at national as well as regional levels. It is obvious that economic sanctions are expected to be more effective if the authors are economic (super)powers. Thus, I selected for this part the United States, the European Union, and Japan, which are generally considered to have the most powerful capacities in this field. Before going into the individual examinations, Chapter 5 (Jean-Marc Thouvenin) describes the long history of implementation of sanctions from ancient times before Christ to the post-World War II era. Chapter 6 (Richard Nephew) gives a comprehensive picture of 200 years of US sanctions history. It neatly describes the complex structure of design, implementation, and enforcement of US sanctions, and it indicates how important it is to understand the way they are created and managed. In order to better understand the similarities and differences between the different implementing States and organizations, Chapters 7 and 8 follow the basic structure of Chapter 6, which consists of history, legal and administrative frameworks, implementing agencies, 
and actual practice. Chapter 7 (Francesco Giumelli) covers the implementation of sanctions by the European Union (EU). It is not an easy task to make those who are not familiar with EU affairs understand the functioning of the EU sanctions due to the EU's unique institutional settings and the continuous evolution of its instrument of sanctions. He has successfully accomplished this task. Chapter 8 (Machiko Kanetake) provides an overview of the Japanese system of imposing sanctions, which has undergone a radical change in this century. It shows how Japan has transformed its policy from a passive applier of international sanctions to an active promoter of autonomous sanctions and how it has adjusted its domestic legal system to the rapidly evolving international sanction regimes.

Part III offers a series of case studies of contemporary relevance. Chapter 9 (Andrea Berger) discusses the North Korea sanctions. As first sanctions for nuclear nonproliferation purposes, they have become the most stringent among all UN sanctions. After examining the UN as well as non-UN sanctions on North Korea, however, she highlights the existence of serious gaps in implementation and the continued practice of North Korean evasion. Chapter 10 (Kazuto Suzuki) deals with Iran sanctions. It has been widely believed that the most important driving force which led Iran to the JCPOA was the UN and non-UN sanctions against the country. From his experience as a member of the UN Panel of Experts, Suzuki observes that the domestic political system was the key to successful sanctions. Chapter 11 (Tatsuya Abe) writes about Syria. Syria is a unique case in that the Security Council failed to adopt a sanction resolution because of the Russian veto, which necessarily led to the instituting of autonomous sanctions. After conducting a comparative study of sanctions imposed by several countries, he concludes that these sanction measures have two major bases of proliferation concerns and reactions to chemical weapons use. Chapter 12 (Mika Hayashi) again provides a unique case of sanctions against one of the permanent members of the UN Security Council. Since the reasons for the sanctions are related to the Russian annexation of Crimea by force, they represent a typical case of resorting to sanctions for reasons of a breach of obligations erga omnes.

Overall, it is this editor's firm belief that the book is a fine collection of wellconceived essays on the theories and practices of economic sanctions, which undoubtedly will make a unique and important contribution to the better understanding of the often complex systems of UN and autonomous sanction regimes and how they have been implemented in actual cases.

Finally, I wish to express my sincere thanks to the Japan Society for the Promotion of Science (JSPS) for its financial assistance in holding the series of symposium on which this publication is partly based. Last but not least, I would also like to extend my gratitude to Routledge, Simon Bates, Shengbin Tan and Georgina Bishop for their excellent work on the publication of this book. 


\section{Part I}

\section{Legal considerations}




\title{
1 Definition and legal justification of sanctions
}

\author{
Masahiko Asada*
}

\section{Introduction}

Sanctions are one of the most important and powerful tools to maintain or restore international peace and security. But until the 1980s, there had only been two cases in which the United Nations (UN) imposed economic sanctions, as far as mandatory sanctions are concerned. ${ }^{1}$ After the end of the Cold War, the function of the UN was revived, and the Security Council began to adopt more sanctions resolutions, with those concerning the Iraqi invasion of Kuwait in 1990 as the turning point. Thus, the 1990s were called the "sanctions decade," designated as such mainly due to UN sanctions.

Contemporaneously, sanctions outside the UN framework became far more visible than before. While the United States continued to maintain its sanctions on Cuba and elsewhere, ${ }^{3}$ regional organizations like the European Union (EU), the African Union (AU), and African sub-regional organizations started to emerge as major players in applying sanction measures without relevant Security Council mandates - the so-called "autonomous" or "unilateral" sanctions. Some of these autonomous sanctions were applied to the same target and for the same, or related, purposes as the UN sanctions.

At the same time, in response to the disastrous impact on the civilian population of the comprehensive trade sanctions on Iraq in the early 1990s, the way in which sanctions were applied was fundamentally reexamined and, as a consequence, it evolved into more selective and targeted ones, which were deemed to be more effective and less inhumane, in both UN and non-UN measures. ${ }^{4}$ Whether this proved to be true or not, as the targeted sanctions may come close to comprehensive ones depending on the concrete measures, ${ }^{5}$ it is the shared view that it was the sanctions imposed in the 2000s and 2010s, both UN and non-UN, that led Iran to enact a major policy change and to enter into a major nuclear agreement, the Joint Comprehensive Plan of Action (JCPOA), with the E3+3 States in 2015, settling what had long been seen as a difficult international security issue.

Even if (or perhaps because) such a view reflects the reality of the situation, from a legal perspective, it is imperative to examine whether such measures are legally justifiable, as sanctions may sometimes involve otherwise unlawful measures. ${ }^{6}$ The examination will be conducted by distinguishing between UN and 
non-UN sanctions, not only because the trend of exerting UN and non-UN sanctions in parallel is expected to continue but also because the possible theories of legal justification applicable to them are quite different. Before proceeding to the examination, it is pertinent to define what "sanction" means in our context, as it has been said that there is no accepted definition of sanctions. ${ }^{7}$

\section{Definition of sanctions}

Sanctions stricto sensu under international law can be defined as

coercive measures taken [in response to a violation of international law] in execution of a decision of a competent social organ, i.e., an organ legally empowered to act in the name of the society or community that is governed by the legal system. ${ }^{8}$

In other words, sanctions stricto sensu do not include, in the first place, such measures that are taken in response to unfriendly or threatening, but still per se lawful, acts. UN enforcement measures (sanctions) are taken in response to a threat to the peace, breach of the peace, or act of aggression (Art. 39 of the UN Charter), which is usually an internationally wrongful act, but not always, ${ }^{9}$ and the legal characterization of such acts may sometimes be ambiguous. ${ }^{10}$ Thus, UN enforcement measures may not be regarded as sanctions stricto sensu.

Second, according to the strict definition of sanctions above, they do not include measures that are taken by individual or a group of States outside the framework of a decision by a competent social organ. This kind of measure is sometimes called an "autonomous" sanction. However, the term "autonomous" sanctions may appear self-contradictory because, according to the definition above, sanctions cannot be imposed autonomously but should be in accordance with a decision made by a competent social organ.

That said, the term "sanctions" has widely been used in practice as something encompassing much more, not only in nonlegal but also in legal literature ${ }^{11}$ as well as in various official documents, both for UN enforcement measures and for autonomous measures. Although the Charter of the United Nations does not use the word "sanctions" anywhere, the Security Council resolutions themselves sometimes refer to the relevant measures as "sanctions." 12 This applies even where they are taken in response to lawful, or not necessarily unlawful, acts. ${ }^{13}$

As for autonomous measures, the autonomous and other measures taken by the United States are called "sanctions" in the title of the relevant legislation. For instance, its legislation imposing certain measures on Iran is designated as the "Comprehensive Iran Sanctions, Accountability, and Divestment Act of 2010."14 By contrast, within the framework of the EU, autonomous measures, as well as measures implementing UN resolutions, are all referred to as "restrictive measures" in its official documents. This is because Article 215 of the Treaty on the Functioning of the European Union (TFEU), which is the legal basis for the relevant EU regulations, refers to the measures for the interruption or reduction of 
economic and financial relations with third countries as "restrictive measures." This does not, however, mean that the EU has never used the term "sanctions." Rather, it sometimes uses this term in tandem with the term "restrictive measures," as in the 2004 Council document entitled, "Basic Principles on the Use of Restrictive Measures (Sanctions)." 15

Thus, "sanctions" has been used as a term broadly covering coercive measures taken against the will of a target State or entity. We will examine such broadly defined, but non-military, "sanctions" in this and other chapters in principle.

\section{Legal justification of UN sanctions}

Sanctions are coercive measures to be taken against the will of a target State or entity and are in some cases per se unlawful. As such, they need to be legally justified. The justifications for such sanctions may be different, depending on whether they are taken under the auspices of the United Nations or they are taken autonomously by a State or a group of States. Even for UN measures, the legal justifications may be different for mandatory and nonmandatory measures.

\section{Legal justification of per se illegal mandatory UN sanctions}

With regard to mandatory UN measures, which are typically provided in a paragraph beginning with the verb "decides" in a Security Council resolution adopted under Chapter VII of the UN Charter after the existence of a threat to the peace is determined, ${ }^{16}$ there are few divergent opinions about how to justify their apparent lack of legality. Legal scholarship, UN practice, and judicial opinions are virtually unanimous in agreeing that obligations under legally binding sanction resolutions of the Security Council must prevail over any other conflicting international legal rights and obligations. ${ }^{17}$

In cases where obligations under such resolutions conflict with those under a treaty to which UN Member States are party along with the target State, the former obligations would prevail by virtue of Article 103 of the UN Charter. Article 103 provides that "[i]n the event of a conflict between the obligations of the members of the United Nations under the present Charter and their obligations under any other international agreement, their obligations under the present Charter shall prevail." Although it refers to the obligations "under the [UN] Charter," they are understood to also include those present under legally binding Security Council resolutions, as has been demonstrated by some Security Council resolutions themselves, ${ }^{18}$ as well as jurisprudence of the International Court of Justice ${ }^{19}$ (ICJ) and other courts and tribunals. ${ }^{20}$

On the other hand, literally, Article 103 only covers a conflict between obligations under the UN Charter and those under another "international agreement" and is not applicable to a case of conflict between the former obligations and those under customary international law. ${ }^{21}$ The drafting history of Article $103^{22}$ and subsequent practice ${ }^{23}$ also supports such an understanding, ${ }^{24}$ although there are views 
supporting a broad interpretation of Article 103 to the effect that it also covers a conflict with customary international law. ${ }^{25}$

Nevertheless, the supremacy of the Charter obligations over those under customary international law may be confirmed by resorting to other rules of international law. Some analysts refer to the rule of lex specialis in this respect. Thus, Professor Nico Krisch, in discussing the reason for Article 103 only dealing with possible conflict with "any other international agreement," argues that "Charter rules were deemed to derogate from general international law as lex specialis, and ... a conflict rule was seen as necessary only for agreements. ${ }^{.26} \mathrm{He}$ goes on to maintain that "[i]n effect, thus, [Security Council] resolutions take precedence over all conflicting rules of international law." ${ }^{27}$

While it is undoubtedly persuasive, such a view might not be entirely correct. When a new customary rule is established following the conclusion of a treaty (including the UN Charter) regulating the same subject, the lex posterior rule may lead to the conclusion that a subsequently established customary rule as a lex posterior takes precedence over a prior treaty rule, unless a different intention on the part of the parties to the treaty is established..$^{28}$ For instance, it seems possible that, notwithstanding the rules set forth in Article 2, paragraph 4, of the UN Charter, a new customary rule allowing the use of force for humanitarian reasons (humanitarian intervention) may emerge to govern international relations between States. ${ }^{29}$ In this case, the lex posterior rule, rather than that of lex specialis, would correctly explain the legal situation.

However, such eventualities seem to arise mainly in cases where the relevant UN obligations are directly provided for in the Charter itself. Regarding obligations under legally binding Security Council resolutions (sanction resolutions, in particular) as special treaty-based obligations, the rule of lex specialis would usually govern the legal situation in cases of conflict between them and those under customary international law. This is because, in the case of a sanction resolution, it can be reasonably expected that, even if a new, conflicting customary rule were to emerge on the subject to which the sanction pertains, it would be the intention of the drafters of the resolution to maintain the sanction measures until the objective of the resolution was accomplished or the sanctions were otherwise terminated, considering that a sanction resolution may be terminated any time by the Security Council.

\section{Legal justification of per se illegal nonmandatory UN sanctions}

\section{(1) UN recommendations}

The legal effect of per se illegal nonmandatory Security Council measures, most frequently provided in a paragraph starting with the phrase "calls upon" in a Council resolution (adopted under Chapter VII), is more complicated. ${ }^{30}$ Article 103 could not apply to these measures, simply because they are not legally binding and cannot be regarded as "obligations" under the UN Charter as stipulated in Article 103. ${ }^{31}$ It is, therefore, not impossible to conclude that States would be 
committing a wrongful act if they acted in accordance with a Security Council resolution "calling upon" them to do so but in contravention with their legal obligations imposed elsewhere vis-à-vis the target State; indeed, some analysts argue somewhat to that effect. ${ }^{32}$ However, it is a sheer fact that in very few cases ${ }^{33}$ have UN Member States protested when other Member States implemented a sanction resolution "calling upon" them to do so because it is not legally binding.

It is, of course, difficult to draw a definitive conclusion from negative practice, since the lack of protest might be the result of a lack of conflicting obligations. Positive practice does exist: for instance, when the United Kingdom stopped a Greek ship on the high seas before the adoption of Resolution 221(1966), "[c]all[ing] upon" the UK government to prevent the arrival at Beira of vessels believed to be carrying oil destined for Southern Rhodesia, the Greek government firmly protested, but after the adoption of the resolution the latter government did not voice any protest against the British stopping a second Greek ship under similar conditions. ${ }^{34}$ Considering the ever-increasing number of bilateral investment agreements or other economic or trade-related agreements, ${ }^{35}$ which may be "violated" by economic sanctions, it would probably be safe to assume that the lack of protest is due to the opinio juris of States that the wrongfulness of per se illegal measures will be precluded by a Council resolution "calling upon" Member States to take those measures.

There have also been some collective instances of positive practice that indicate the existence of such opinio juris. In 1951, the Collective Measures Committee established by the UN General Assembly in accordance with paragraph 11 of Resolution 377 (V), discussed the question of legal liabilities of a State on account of its carrying out collective measures decided upon or recommended by the Security Council or the General Assembly for the purpose of maintaining or restoring international peace and security. As a result of the discussion, the Committee adopted a report containing the following conclusions:

In the event of a decision or recommendation of the United Nations to undertake collective measures, the following guiding principles should be given full consideration by the Security Council or the General Assembly and by States:

(i) Guiding principles of general application: ...

(d) It is of importance that States should not be subjected to legal liabilities under treaties or other international agreements as a consequence of carrying out United Nations collective measures. ${ }^{36}$

(emphasis added)

Three points are worth noting here. First, presumably in light of the doubts expressed during the debate regarding whether Article 103 could legally apply to recommendations, that article was not mentioned in the report by the Committee. ${ }^{37}$ Second, the thrust of the principle here seems to be that the wrongfulness of 


\section{Masahiko Asada}

the action would be precluded if it is taken to carry out UN collective measures. ${ }^{38}$ Third, what is said in the report covers the recommendations of not only the Security Council but also the General Assembly.

Another, more recent, indication that shows sanctions implemented in accordance with recommendations made by the United Nations would not carry legal liabilities can be found in a commentary adopted during the drafting of the Articles on State Responsibility in 1979. Although it might not be practice stricto sensu, the International Law Commission, in addressing the question of countermeasures and sanctions within the framework of the topic of State Responsibility, adopted a commentary on first reading, containing the following statement:

[S]anctions applied in conformity with the provisions of the Charter would certainly not be wrongful in the legal system of the United Nations, even though they might conflict with other treaty obligations incumbent upon the State applying them. Indeed, this view has never been contested. . . The view would, moreover, seem to be valid not only in cases where the duly adopted decision of the Organization authorizing the application of a sanction is mandatory for the Member States but also where the taking of such measures is merely recommended. ${ }^{39}$

(emphasis added)

It should be noted that the points made earlier in relation to the report of the Collective Measures Committee seem to also generally apply here, with a possible proviso regarding the third comment, as there is no explicit reference to the General Assembly recommendations here. Indeed, General Assembly practice in this regard has not accumulated to the same degree as that of the Security Council. While logical thinking should lead to the same conclusions with regard to both organs, as our proposition of customary UN law (see the following) is based on practice, it may be necessary to carefully examine whether there has emerged a customary UN law in relation to General Assembly recommendations as well. ${ }^{40}$

That said, we could perhaps assume that the lack of protest against the taking of sanction measures when called upon by the Security Council is due to the opinio juris held by UN members that that is not unlawful; thus, it could safely be said that there has emerged a rule of "customary United Nations law," to the effect that taking per se illegal measures when States are "called upon" to take them by the Security Council can be justified as lawful. In other words, a paragraph of a Security Council resolution "calling upon" Member States to take measures is not legally binding on them but has the legal effect of precluding the possible wrongfulness of the measures taken in accordance with it. It is important to distinguish between the legally binding nature and the legal effect of the paragraph: the former indicates the obligation of the addressees of the paragraph to take the prescribed measures, and the latter signifies the legal effect of precluding the per se wrongfulness of taking the prescribed measures and also obliging the target State to tolerate those measures. 


\section{(2) UN authorizations}

When it comes to "authorizations," which may be regarded as being located somewhere between mandatory and recommendatory measures, there are not only strong academic arguments but also a domestic judicial judgment, justifying them by directly resorting to Article 103 of the UN Charter.

In the $A l-J e d d a$ case, the applicant, ${ }^{42}$ who had been interned in Iraq for imperative reasons of security in the country, demanded an order to release him on account of the alleged violation of his rights under Article 5, paragraph 1, of the European Convention on Human Rights (right to liberty and security). ${ }^{43}$ In its 2007 judgment in this case, the UK House of Lords dealt with a Security Council resolution "authori[zing]" a multinational force to "take all necessary measures to contribute to the maintenance of security and stability in Iraq" in accordance with the letters (which refers to "internment") annexed to the resolution. ${ }^{44}$ It treated Article 103 as applicable to Security Council authorization resolutions through its purposive interpretation to give effect to the mission of the UN (maintaining peace and security in the world) and in light of the practice of the UN and its Member States. ${ }^{45}$ In doing so, the judgment heavily relied on a "persuasive body of academic opinion," which, while admitting that "in case a State is not obliged but merely authorized to take action, it remains bound by its conventional obligations," argues that such a result would not correspond with State practice and would compromise the very idea of authorizations as a necessary substitute for direct action by the Security Council at least as regards authorizations of military action, and that the same conclusion seems warranted with respect to authorizations of economic measures. ${ }^{46}$ Thus, the cited academic opinion also relied on the twofold justification (effectiveness of the UN mission and State practice) in reaching the conclusion that rule of Article 103 applies to all action under Articles 41 and 42 of the UN Charter, not only to mandatory measures.

While their dual justification is persuasive on its face, it does not necessarily seem to persuasively defend their argument for the applicability of Article 103. The first justification seems to be simply claiming that the UN mission of maintaining international peace and security is important and its effectiveness should not be compromised. This is politically correct; legally, however, it may be criticized as not justifying its own interpretation of Article $103 .{ }^{47}$ The second justification is more of a legal one; but, again, it does not necessarily justify the applicability of Article 103, either.

Perhaps a more legally persuasive justification would rely more on the element of practice, not in the context of the applicability of Article 103 but in relation to the emergence of a customary rule. As is the case with recommendatory measures the Security Council "[c]alls upon" Member States to take, it could be argued concerning Council authorizations that with the continuous absence of protest on the basis of existence of conflicting international obligations, we could safely assume that a rule of "customary United Nations law" has emerged and been established to the effect that taking a per se illegal action in accordance with authorization by the Security Council precludes its apparent wrongfulness. 


\section{Definition and legal justification of autonomous sanctions}

\section{Definition of autonomous sanctions}

Sanctions are not a monopoly of the UN Security Council or the United Nations as a whole. The imposition of autonomous (or unilateral) sanctions outside the framework of the United Nations has become increasingly popular. In the early 1990s, the Member States of the European Union started to agree on sanctions in the absence of a UN mandate. ${ }^{48}$ Similarly, African regional organizations have imposed sanctions based on their own rules for more than a decade. Individual States, such as the United States, have exerted sanction measures independently of UN resolutions for a far longer time. ${ }^{49}$

Among the major reasons for individual or regional autonomous sanctions beyond the UN mandate, the following has been pointed out. ${ }^{50}$ First, the Security Council is sometimes slow in reacting to international crises or remains deadlocked due to the casting, or the threat, of a veto by some of its permanent members; thus it is, in the view of some States, not necessarily effective in addressing the problems of rapidly evolving international relations. Second, conversely, individual States or regions may be more cautious than the Security Council in lifting sanctions; therefore, an originally UN-based sanction may become an autonomous sanction. This might happen to States that are not permanent members of the Council, its permanent members being able to veto the termination resolution to maintain the UN sanction.

Whatever the reasons, the legal character of the so-called autonomous sanctions is not the same in all cases. Accordingly, the legal justification for imposing otherwise unlawful measures is not the same in all cases, either. Considering this, apparently autonomous sanctions may be classified and analyzed in the following three ways in terms of possible legal justification.

First, with respect to their relationship with Security Council resolutions, autonomous sanctions must not, by definition, have relations with such resolutions. However, some of the apparently "autonomous" sanctions may be understood as the implementation of some of the provisions of a general character in a Council resolution. For instance, when a Council resolution imposes sanctions (mandatory or otherwise) on individuals or entities meeting certain conditions (e.g., acting on behalf, or at the direction, of an already designated individual or entity) without specifically naming the target individuals or entities, a Member State might designate certain specific individuals or entities in its national list of sanctions. The sanctions thus imposed may be rightly considered autonomous in the sense that the designation is autonomously made beyond the relevant resolution and according to the State's own choice. They may also be considered autonomous because the designating State must bear any accountability and responsibility for its designation. In terms of legal justification, nevertheless, such sanctions can be justified by reference to a specific enabling provision of the resolution, subject to its "correct" interpretation, of course. Accordingly, these types of sanctions are not regarded as autonomous in this chapter, although other contributors to this book may treat them as autonomous sanctions for good reasons, as discussed earlier. 
Second, even when there is no provision in the relevant Security Council resolution to justify imposing specific, apparently autonomous, sanction measures, they may still be justified if the target State has given prior consent to the measures. There are two different methods of giving consent in this respect. One is to give it through an international agreement. A well-known example of this type can be found in the dispute settlement mechanism of the WTO. Article 22 of the WTO Dispute Settlement Understanding (DSU) provides that if no satisfactory compensation has been agreed upon after negotiations then the complaining party may request authorization from the Dispute Settlement Body (DSB) to suspend the application of concessions or other obligations under the covered agreements to the member concerned.

The second method of giving prior consent to sanctions is to give it on an ad hoc basis. It may generally be inconceivable for the "target" State to give consent to imposing sanctions against itself. However, if they are primarily aimed at non-State actors or a de facto government located within a State's territory, the territorial State (its de jure government) may support, or even request, the imposition of sanctions on the State in order to inflict a blow to its domestic opponents. Although there are a number of such cases in the UN sanctions context, ${ }^{51}$ they have not attracted much attention, perhaps because of the strong justifying effect of the Security Council resolutions. It is equally possible that a State may agree to, or request, sanctions against itself outside the framework of the UN.

Whichever method is used to give consent, these may not be regarded as cases of "sanctions" in the first place, since the target State itself has consented to the measures; thus, they have neither been imposed against the will of the State, nor are they coercive. One may also make an argument that the possible wrongfulness of such "sanctions" is precluded by the consent.

Without any such formal agreement, such as the WTO Dispute Settlement Understanding, or any ad hoc consent to a sanction against oneself, sanction measures may still be justified by invoking countermeasures under general international law. This is the third possible method of justifying the imposition of per se illegal autonomous sanctions, which will be examined in detail in the following section as the most plausible justification for such sanctions.

\section{Legal justification of autonomous sanctions}

\section{(1) General theory of countermeasures}

For otherwise internationally wrongful acts to be legally justified under international law without any prior consent by the suffering State or any specific or general Security Council decisions, authorizations or recommendations, they ought to constitute lawful countermeasures. For a countermeasure to be lawful, it must meet several requirements, including the occurrence of a prior internationally wrongful act by the target State, a requirement to first call for fulfillment of the obligation, a requirement of proportionality, and compliance with the prohibition of the use of force as well as with certain other rules. ${ }^{52}$ In examining possible 


\section{Masahiko Asada}

justification by reference to countermeasures, our focus will be placed on the question of "standing" as the author of countermeasures, ${ }^{53}$ that is, who is entitled to take them. This is because the question posed here is whether autonomous sanctions imposed by States, particularly by third States, can be justified. The examination will be made considering the articles relevant to countermeasures in the Articles on State Responsibility (ASR) of 2001, as well as the commentary thereon prepared by the International Law Commission (ILC) (hereinafter referred to as the "ILC Commentary"). ${ }^{54}$

There is no dispute about the "injured State" having the standing to institute countermeasures. This is confirmed by the ILC in Article 49, paragraph 1, of the ASR, which provides that "[a]n injured State may only take countermeasures against a State which is responsible for an internationally wrongful act." What, then, is an "injured State"? Although the ASR does not contain any definition clause defining an "injured State," Article 42 in effect defines an "injured State" by providing as follows:

A State is entitled as an injured State to invoke the responsibility of another State if the obligation breached is owed to:

(a) that State individually; or

(b) a group of States including that State, or the international community as a whole, and the breach of the obligation:

(i) specially affects that State; or

(ii) is of such a character as radically to change the position of all the other States to which the obligation is owed with respect to the further performance of the obligation.

(emphasis added)

The chapeau part covers the question of standing by providing that an "injured State" is entitled to "invoke the responsibility of another State," including, according to Article 49, by taking countermeasures. Article 42 also specifies three different kinds of obligations/situations in which countermeasures and other measures to invoke responsibility may be taken.

The first situation (Art. 42, para. (a)) may occur when an obligation of a State owed to another State is breached. In this case, the latter State is the injured State. This is the case of a breach of obligations of a bilateral nature ("bilateral obligations"). Bilateral obligations are not necessarily limited to those arising from bilateral treaties. Those contained in a multilateral treaty or found in customary international law might also be characterized as bilateral obligations, such as the obligation of the receiving State to protect the premises of a mission of the sending State, as provided in Article 22 of the Vienna Convention on Diplomatic Relations. ${ }^{55}$ The essence of bilateral obligations in a multilateral treaty or in customary international law is that they are "bilateralizable" 56 in the sense that they can be perceived essentially as bilateral relations. The obligations other than those of a 
bilateral nature are called "collective obligations," which are owed to a group of States or to the international community.

The second situation (Art. 42, para. (b)(i)) in which an injured State may be identified may take place when a collective obligation is breached and a State of the group or of the international community is "specially affected" by the breach. In this case, the "specially affected" State is the injured State. A typical example is a breach of the prohibition of aggression. This prohibition is owed to the international community as a whole, and its breach necessarily involves a specially affected State (i.e., the victim of the aggression), which is considered the injured State.

The third situation (Art. 42, para. (b)(ii)) also covers similar cases in which a collective obligation is breached, but it is further specified by the condition that the breach of the obligation is "of such a character as radically to change the position of all the other States to which the obligation is owed with respect to the further performance of the obligation." This type of obligation is often called an "interdependent obligation." It is so called because "each party's performance is effectively conditioned upon . . the performance of each of the others." ${ }^{57}$ In other words, the performance of the obligation by each party is necessarily dependent on an equal or corresponding performance by all the others.

Designations aside, typical examples of such obligations can be found in a disarmament treaty or a nuclear-free zone treaty, according to the ILC Commentary. ${ }^{58}$ If a party to the disarmament treaty developed or possessed prohibited weapons in breach of the obligation not to develop or possess them, it would almost necessarily lead to a corresponding nonperformance of that obligation by other parties to the treaty. The ILC Commentary states that, in the case of such a breach of an interdependent obligation, all other members of the group of States should be considered "injured States," as they may all be equally affected by the breach. ${ }^{59}$ In that sense, a breach of an interdependent obligation might be equated with a breach of a bilateral obligation or a breach of a collective obligation specially affecting a particular State.

Note in this connection, however, according to Article 42, paragraph (b)(ii), the above equation only applies to the cases in which "the breach of the obligation" is "of such a character as radically to change the position of all the other States ... with respect to the further performance of the obligation"; in other words, such an equation is limited to cases in which not only the obligation is interdependent in nature but the breach is also so significant as to "radically change the position of all the other States," and perhaps it is significant enough to be equated with the breach of a bilateral obligation or the breach of a collective obligation specially affecting a particular State in terms of the effect to the latter State. ${ }^{60}$

The ILC Commentary on Article 42, paragraph (b)(ii), implicitly confirms this by stating that:

[e]ven under such treaties [establishing particular regimes involving interdependent obligations], it may not be the case that just any breach of the 


\section{Masahiko Asada}

obligation has the effect of undermining the performance of all the other States involved, and it is desirable that this subparagraph be narrow in its scope. ${ }^{61}$

(emphasis added)

Hence, only when the breach of an interdependent obligation is significant may all the other States of the group or of the international community be considered injured States and thus entitled to take countermeasures against the wrongdoer.

Coming back to the question of autonomous sanctions and their possible justification by reference to countermeasures, the most relevant among the previously discussed three situations would be the third one (a significant breach of interdependent obligation) because autonomous sanctions have been imposed and are supposed to continue to be imposed by States, including those whose rights or other legal interests are not individually infringed upon or specially affected. Taking a breach of a disarmament treaty as an example of a typical treaty containing interdependent obligations, it could be concluded from the discussions here that only a significant breach of the disarmament obligation may lead to lawful countermeasures, and thus lawful autonomous sanctions, against the breaching State by any of the other parties to the treaty as an injured State.

\section{(2) Invocation of responsibility by a "State other than an injured State"}

What, then, would happen if the requirement of significance applicable to the breach of an interdependent obligation under Article 42, paragraph (b)(ii), were not met in a specific case? The answer would naturally be that the other parties to the treaty or the other States in the international community would not be regarded as injured States. This does not, however, mean that the other parties to the treaty or the other States in the international community in such a case cannot invoke the responsibility of the wrongdoing party or State at all. Article 48 of the ASR, entitled "Invocation of responsibility by a State other than an injured State," provides the following rule on this point:

1. Any State other than an injured State is entitled to invoke the responsibility of another State in accordance with paragraph 2 if:

(a) the obligation breached is owed to a group of States including that State, and is established for the protection of a collective interest of the group; or

(b) the obligation breached is owed to the international community as a whole.

2. Any State entitled to invoke responsibility under paragraph 1 may claim from the responsible State:

(a) cessation of the internationally wrongful act and assurances and guarantees of non-repetition in accordance with article 30; and

(b) performance of the obligation of reparation in accordance with the preceding articles, in the interest of the injured State or of the beneficiaries of the obligation breached. 
As the ILC Commentary expressly states, Article 48 provides for the cases of a breach of an obligation erga omnes partes (Art. 48, para. 1(a)) and of an obligation erga omnes (Art. 48, para. 1(b)). Obligations erga omnes, according to the ICJ judgment in the Barcelona Traction case, are "the obligations of a State towards the international community as a whole" and "are the concern of all States" by their very nature. The Court also said that "[i]n view of the importance of the rights involved, all States can be held to have a legal interest in their protection" and listed, as examples of such obligations, those deriving from the prohibition of aggression, genocide, slavery, and racial discrimination. ${ }^{62}$ To these, one may now be able to add certain obligations concerning the environment, human rights, or security. ${ }^{63}$ Obligations erga omnes partes are obligations of a similar nature that are owed to a group of States (as opposed to the international community as a whole, applicable in the case of obligations erga omnes), such as those contained in certain multilateral treaties.

In terms of the nature of obligations, what is the relationship and difference between those dealt with in Article 42, paragraph (b) and those in Article 48, paragraph 1, both concerning collective obligations, but with the former involving injured States and the latter referring to States other than injured States? To limit the examination here to treaty-based collective obligations (those in the first half of Art. 42, para. (b), and those in Art. 48, para 1(a)), Article 42, paragraph (b), covers obligations owed to a group of States (i.e., collective obligations), while Article 48, paragraph 1(a), deals with certain types of collective obligations that are established "for the protection of a collective interest of the group" (i.e., obligations erga omnes partes). Because of the additional element ("for the protection of a collective interest of the group") added in Article 48, "obligations erga omnes partes" can be regarded as a subset of "collective obligations."

Moreover, "interdependent obligations," as set forth in Article 42, paragraph (b)(ii), can be regarded as a subset of "obligations erga omnes partes," because it is obvious that interdependent obligations, the performance of which by each party is necessarily dependent on a corresponding performance by all the other parties, cannot only be regarded as protecting a collective interest of the parties (i.e., obligations erga omnes partes) but also be more restrictive in scope than obligations erga omnes partes. For the latter obligations are designed simply to protect a collective interest of the group, while the former obligations are such that each party's performance of the obligations would necessarily affect others' corresponding performance. In short, interdependent obligations are part of obligations erga omnes partes, the latter being part of collective (nonbilateral) obligations.

Another point to be made regarding the relationship and difference between Article 42, paragraph (b), and Article 48, paragraph 1, concerns the nature of the breach of obligations. Unlike in Article 42, paragraph (b)(ii), there is no "significance" threshold of a breach for the application of Article 48. While the former provision states that "the breach . . . is of such a character as radically to change the position of all the other States," the latter simply provides that "[a]ny State other than an injured State is entitled to invoke the responsibility of another State ... if the obligation breached is [of erga omnes partes nature]." Accordingly, 
Article 48 would apply to any breach of obligation erga omnes partes, regardless of the gravity or nature of the breach.

If the examination above is correct, it would follow that when a breach of an interdependent obligation does not reach the significance threshold for the application of Article 42, paragraph (b)(ii), as discussed earlier, it can still be dealt with under Article $48^{64}$ because interdependent obligations are a subset of obligations erga omnes partes and, therefore, Article 48 would apply to their breach, independently of the significance of the breach. It is, therefore, not surprising that a nuclear-free zone treaty is mentioned as an example in the ILC Commentary not only with regard to Article 42, paragraph (b)(ii) (on interdependent obligations) but also in relation to Article 48, paragraph 1(a) (on obligations erga omnes partes). ${ }^{65}$

What, then, are the measures that "a State other than an injured State" may take under Article 48? On this point, Article 48, paragraph 2, provides that such a State may claim from the responsible State: (1) cessation of the internationally wrongful act and assurances and guarantees of nonrepetition and (2) performance of the obligation of reparation in the interest of the injured State or of the beneficiaries of the obligation breached. According to the commentary on Article 48, paragraph 2 , this list of measures is "exhaustive," measures. Does this mean that if a breach of an interdependent obligation (such as one in a disarmament treaty) is not significant enough to meet the significance threshold of Article 42, paragraph (b)(ii), then the other parties to the treaty, not being injured States, are completely precluded from resorting to countermeasures/ autonomous sanctions in accordance with Article 48 ?

\section{(3) Countermeasures by a "State other than an injured State"}

Whether States covered by Article 48, paragraph 1 (i.e., "States other than injured States" in the case of a breach of an obligation erga omnes partes/erga omnes) can resort to countermeasures/autonomous sanctions is, in fact, not clear. Article 54, entitled "Measures taken by States other than an injured State," provides:

This Chapter [on Countermeasures] does not prejudice the right of any State, entitled under article 48, paragraph 1, to invoke the responsibility of another State, to take lawful measures against that State to ensure cessation of the breach and reparation in the interest of the injured State or of the beneficiaries of the obligation breached.

(emphasis added)

Whether the States covered by Article 48, paragraph 1, can resort to countermeasures depends on the interpretation of "lawful measures" in the provision above. There may be two interpretations of what "lawful measures" means here. ${ }^{67}$ On the one hand, one may argue that "lawful measures" should be understood as measures that are lawful per se, i.e., retorsion and not countermeasures. On the other hand, it could be argued that retorsion as an originally lawful act is, by definition, 
excluded from the scope of the Articles on State Responsibility since they deal with an internationally wrongful act, as the full title of the Articles - "Articles on Responsibility of States for Internationally Wrongful Acts" - indicates. It can also be maintained that expressly permitting retorsion does not make sense, given that it is lawful anyway. It may further be noted that Article 54 is placed in Part 3, Chapter II, of the Articles, which is entitled "Countermeasures." Thus, the other view holds that the "lawful measures" in Article 54 must be countermeasures.

Obviously, the second view is far more persuasive, but Article 54 does not explicitly provide that "States other than injured States" as identified in Article 48 are entitled to take "countermeasures." Rather, according to the ILC Commentary on Article 54,

the current state of international law on countermeasures taken in the general or collective interest is uncertain. ... At present there appears to be no clearly recognized entitlement of States referred to in Article 48 to take countermeasures in the collective interest. ${ }^{68}$

This is not an outright denial of the possible existence of such entitlement, either. The ILC Commentary continues:

Consequently, it is not appropriate to include in the present articles a provision concerning the question whether other States, identified in article 48, are permitted to take countermeasures in order to induce a responsible State to comply with its obligations. Instead, chapter II includes a saving clause which reserves the position and leaves the resolution of the matter to the further development of international law. ${ }^{69}$

(emphasis added)

Thus, whether a "State other than an injured State," as identified in Article 48, can resort to countermeasures depends on the development of State practice in this field. While State practice, as shown in this book, may be interpreted as increasingly supporting a State's standing of instituting countermeasures, some States, such as Russia and China, still express concern over the "imposition of unilateral coercive measures not based on international law, also known as 'unilateral sanctions." " 70

Accordingly, nearly 20 years from the adoption of the ASR, it remains somewhat uncertain whether a State can institute countermeasures/autonomous sanctions against another that has committed a less-than-significant breach of an interdependent obligation (e.g., a disarmament obligation) or a breach of other obligations erga omnes partes/erga omnes (e.g., the prohibition of aggression or genocide).

\section{Conclusions}

We live in an era of sanctions. They are reported almost daily in news reports on North Korea, Iran, Syria, Russia, and many other States. However, the topic of 
the legality of sanction measures is explored less than it should be, despite the fact that such measures might be per se illegal in light of the treaties the sanctioning State has concluded with the target State or in light of customary international law rules applicable to them. Indeed, some such sanction cases have recently been submitted to the International Court of Justice for adjudication. ${ }^{71}$ The present chapter has attempted to fill such a gap.

It may generally be felt that sanctions imposed within the UN framework involve few legal problems, if any, thanks to the supremacy of UN Charter obligations stipulated in Article 103. However, there is controversy regarding whether all UN sanction resolutions are covered by that article. The author opines that, among those resolutions, Security Council decisions (legally binding) are covered by that article, while Security Council recommendations and authorizations (not legally binding) are not, simply because they do not represent the "obligations under the ... Charter" (Art. 103). However, this does not mean that the latter types of resolutions cannot trump other international obligations. It is submitted that there has emerged and become established a United Nations customary rule to the effect that the apparent wrongfulness of per se illegal sanction measures is precluded if they are taken in accordance with a Security Council recommendation or authorization.

The legal situation surrounding non-UN, or autonomous, sanctions is not so simple. Absent a comparable supremacy clause or practice, and absent prior consent made by the target State, they must be justified in accordance with general international law. Such justification seems to be made only by resorting to the rules on countermeasures. Autonomous sanctions have been instituted not only by States directly affected by the preceding wrongful act but also by not-so-affected States. For autonomous sanctions to be fully justified, therefore, it is imperative for the latter kind of States to be entitled to take countermeasures. According to the 2001 Articles on State Responsibility, countermeasures can only be instituted by the "injured State." In a significant breach of interdependent obligations, such as those of a disarmament treaty, all the other parties to the treaty become injured States and, as such, could take countermeasures/autonomous sanctions. However, in cases of not-significant breaches of interdependent obligations or of breaches of other obligations erga omnes partes/erga omnes, such as the prohibition of aggression or genocide, the legal situation is less clear. The interpretation would depend on the development of relevant State practice, possibly including the episodes discussed in this book.

\section{Notes}

* The author is indebted to the Japan Society for the Promotion of Science (JSPS) for its support for the research on which this chapter is based.

1 They are the cases of Southern Rhodesia and South Africa.

2 David Cortright and George A. Lopez, The Sanctions Decade (2000).

3 See Chapter 6 of this book.

4 See Targeted Financial Sanctions: A Manual for Design and Implementation (2001), available at $<\mathrm{https}$ ://reliefweb.int/sites/reliefweb.int/files/resources/A878420AFCAE47 
CDC1256DE800309A85-SwissGov_sanctions_2001.pdf $>$. See also U.N. Doc. A/54/2000 (March 27, 2000), para. 232.

5 Financial sanctions on selective major banks of the target State may have a major impact on it, just like a comprehensive trade sanction.

6 As just one example of allegedly unlawful sanction measures, see "Putin Says US, EU Sanctions Violate WTO," Deutsche Welle (September 18, 2014), available at <www. dw.com/en/putin-says-us-eu-sanctions-violate-wto/a-17932934>. See also infra note 71.

7 Natalino Ronzitti, "Sanctions as Instruments of Coercive Diplomacy: An International Law Perspective," in Natalino Ronzitti ed., Coercive Diplomacy, Sanctions and International Law (2016), p. 9.

8 Georges Abi-Saab, "The Concept of Sanction in International Law," in Vera GowllandDebbas ed., United Nations Sanctions and International Law (2001), pp. 29-41, esp. pp. 32-33 and 39; and Alain Pellet and Alina Miron, "Sanctions," in Rüdiger Wolfrum ed., The Max Planck Encyclopedia of Public International Law, Vol. IX (2012), pp. 1-2.

9 See, e.g., Benedetto Conforti and Carlo Focarelli, The Law and Practice of the United Nations, 5th ed. (2016), p. 251; and Simon Chesterman, Thomas M. Franck, and David M. Malone, Law and Practice of the United Nations (2008), p. 342.

10 The traditional view is that the finding of a threat to the peace under Article 39 of the UN Charter does not necessarily depend on the finding of a violation of international law. Hans Kelsen, The Law of the United Nations (1951), p. 294; H. Lauterpacht ed., Oppenheim 's International Law, Vol. II, 7th ed. (1952), p. 163; and Vera GowllandDebbas, "Security Council Enforcement Action and Issues of State Responsibility," International and Comparative Law Quarterly, Vol. 43, Pt. 1 (1994), p. 61.

11 See, e.g., Pellet and Miron, supra note 8, pp. 1-12.

12 See, e.g., U.N. Doc. S/RES/1929 (2010) (June 9, 2010), para. 11. See also ibid., paras. 19, 20, 26.

13 Security Council Resolution 1718(2006) imposed certain measures on the DPRK in response to the nuclear test by the latter, which the Council determined as a "clear threat to international peace and security." If the DPRK was regarded as having withdrawn from the NPT, the nuclear test was not necessarily unlawful under international law. The measures imposed thereby have been called "sanctions" in subsequently adopted resolutions. See, e.g., U.N. Doc. S/RES/2371 (2017) (August 5, 2017), paras. $19-22$.

14 See <www.treasury.gov/resource-center/sanctions/Documents/hr2194.pdf $>$.

15 Council of the European Union, "Basic Principles on the Use of Restrictive Measures (Sanctions)" (June 7, 2004), which covers both UN and non-UN (autonomous) sanctions. See <http://register.consilium.europa.eu/doc/srv?l=EN\&f=ST\%2010198\%20 2004\%20REV\%201>.

16 Michael Wood, "The UN Security Council and International Law," Hersch Lauterpacht Memorial Lectures, University of Cambridge (November 7-9, 2006), p. 14.

17 For an argument that Article 103 of the UN Charter covers not only a conflict between obligations under the Charter and "obligations" under other international agreements but also a conflict between the former obligations and "rights" arising from other international agreements, see Erika de Wet, The Chapter VII Powers of the United Nations Security Council (2004), p. 183.

18 For instance, Security Council Resolution 670 (1990), after recalling "the provisions of Article 103 of the [UN] Charter" in its preamble, decided under Chapter VII of the Charter that "all States, notwithstanding the existence of any rights or obligations conferred or imposed by any international agreement . . . entered into . . . before the date of the present resolution, shall deny permission to any aircraft to take off from their territory." U.N. Doc. S/RES/670 (1990) (September 25, 1990), para. 3. Note also that it refers not only to "obligations" but also to "rights." 
19 "Questions of Interpretation and Application of the 1971 Montreal Convention Arising from the Aerial Incident at Lockerbie (Libyan Arab Jamahiriya v. United States of America)," ICJ Reports 1992, Order (April 14, 1992), p. 126, para. 42; and "Questions of Interpretation and Application of the 1971 Montreal Convention Arising from the Aerial Incident at Lockerbie (Libyan Arab Jamahiriya v. United Kingdom)," ICJ Reports 1992, Order (April 14, 1992), p. 15, para. 39.

20 See, e.g., Court of First Instance of the European Communities, Kadi v. Council and Commission, Case T-315/01, Judgment (September 21, 2005) (hereinafter cited as "Kadi I"), paras. 183-184.

21 See, e.g., Geoffrey R. Watson, "Constitutionalism, Judicial Review, and the World Court," Harvard International Law Review, Vol. 34, No. 1 (1993), p. 25; Derek Bowett, "The Impact of Security Council Decisions on Dispute Settlement Procedures," European Journal of International Law, Vol. 5, No. 1 (1994), p. 92; and Alexander Orakhelashvili, "Article 30," in Olivier Corten and Pierre Klein eds., The Vienna Convention on the Law of Treaties (2011), p. 782, MN 46.

22 During the drafting of what later became Article 103 in San Francisco, an amendment was proposed to drop the reference to "international agreement" and replace it with text providing for the supremacy of the Charter-based obligations over "any other international obligations to which [the members of the United Nations] are subject." However, the original language was retained, with some minor editorial changes, to become the final provision. See Documents of the United Nations Conference on International Organization, Vol. 13, pp. 706-708; ibid., Vol. 17, pp. 112-113; and ibid., Vol. 18, p. 342. See also Jean Combacau, Le pouvoir de sanction de I'O.N.U. (1974), p. 282.

23 For instance, during the drafting of the Declaration on Principles of International Law concerning Friendly Relations and Co-operation among States in accordance with the Charter of the United Nations of 1970, a question was raised regarding whether the primacy of the Charter obligations over those under "any other international agreement" should be extended to those arising from "customary law and other sources of international law." However, the final product retained the original idea of Article 103 in this respect. See Repertory of Practice of United Nations Organs, Vol. 4, Supplement No. 3 (1959-1966), p. 214, paras. 89-90.

24 Rain Liivoja, "The Scope of the Supremacy Clause of the United Nations Charter," International and Comparative Law Quarterly, Vol. 57, Pt. 3 (2008), pp. 602-608.

25 Andreas Paulus and Ruben Leiss, "Article 103," in Bruno Simma, Daniel-Erasmus Khan, Georg Nolte, and Andreas Paulus eds., The Charter of the United Nations, 3rd ed. (2012), p. 2133. See also Kadi I, supra note 20, para. 156.

26 Nico Krisch, "Introduction to Chapter VII," in Simma, Khan, Nolte, and Paulus eds., supra note 25, p. 1262. See also Vera Gowlland-Debbas, "The Limits of Unilateral Enforcement of Community Objectives in the Framework of UN Peace Maintenance," European Journal of International Law, Vol. 11, No. 2 (2000), p. 370.

27 Krisch, supra note 26, p. 1262.

28 Concerning the relationship between a new customary law rule and a prior treaty provision, Nancy Kontou argues that new customary law may be invoked as a ground for the termination or revision of a prior treaty if it is incompatible with the treaty provisions, and it is binding all parties to the treaty, unless the parties intended that the treaty should continue applying as special law. Nancy Kontou, The Termination and Revision of Treaties in the Light of New Customary International Law (1994), pp. 146-148.

29 Professor Ian Brownlie points out that "[ $\mathrm{t}]$ here can be no doubt that the United Nations Charter can be modified by the congruent practice of the Member States crystallising as a new principle of customary law." Ian Brownlie and C.J. Apperley, "Kosovo Crisis Inquiry," International and Comparative Law Quarterly, Vol. 49, Pt. 4 (2000), p. 894. See also Kontou, supra note 28, pp. 22-23; Mark E. Villiger, Customary International Law and Treaties, 2nd ed. (1997), p. 221; Karol Wolfke, "Treaties and Custom," in Jan Klabbers and René Lefeber eds., Essays on the Law of Treaties (1998), p. 35; Paul 
Reuter, Introduction au droit des traités (1985), p. 117, para. 205; and Patrick Daillier, Mathias Forteau, et Alain Pettet, Droit International Public (Nguyen Quoc Dinh), 8e éd. (2009), pp. 325-326.

30 For various opinions on this question, see Jarna Petman, "Resort to Economic Sanctions by Not Directly Affected States," in Laura Picchio Forlati and Linos-Alexandre Sicilianos eds., Les sanctions économiques en droit international (2004), pp. 330-331.

31 This view has been shared by analysts. See, e.g., Combacau, supra note 22, p. 284; Alix Toublanc, "L'article 103 et la valeur juridique de la Charte des Nations Unies," Revue générale de droit international public, tome 108 (2004), p. 446; and Paulus and Leiss, supra note 25, p. 2127.

One of the best-known contrary views concerning the legally binding nature of a resolution can be found in the ICJ's advisory opinion in the Namibia case, in which it held that paragraph 5 of Resolution 276 (1970), "[c]all[ing] upon all States . . . to refrain from any dealings with the Government of South Africa which are inconsistent with paragraph 2 of the present resolution," was binding all UN Member States. "Legal Consequences for States of the Continued Presence of South Africa in Namibia (South West Africa) Notwithstanding Security Council Resolution 276 (1970)," ICJ Reports 1971, Advisory Opinion (June 21, 1971), p. 53, para. 115. See also Leland M. Goodrich, Edvard Hambro, and Anne Patricia Simons eds., Charter of the United Nations, 3rd ed. (1969), p. 211 and pp. 312-313.

32 See, e.g., Nigel D. White and Ademola Abass, "Countermeasures and Sanctions," in Malcom D. Evans ed., International Law, 4th ed. (2014), p. 556 ("If the Security Council or the General Assembly only recommend sanctions, it is questionable whether this entitles States (if they choose) to suspend treaty obligations"); and Jochen Abr. Frowein, "Article 39," in Bruno Simma ed., The Charter of the United Nations (1995), p. 615, MN 33 ("it does not appear possible to justify enforcement measures on the basis of a recommendation according to Article 39 which would interfere with the international legal rights of the affected state").

33 Although it is not a case of protest against taking measures, one of the rare cases in which a Security Council recommended sanction was refused on the basis of its conflict with treaty commitments was the Dutch refusal to take action against South Africa in 1983, for the reason that it would conflict with its obligations under the EEC and ECSC Treaties, as well as those under the Benelux Economic Union and the GATT. Robert Kolb, "Does Article 103 of the Charter of the United Nations Apply Only to Decisions or Also to Authorizations Adopted by the Security Council?" Zeitschrift für ausländisches öffentliches Recht und Völkerrecht, Vol. 64, No. 1 (2004), p. 28.

34 Ibid., p. 28.

35 For instance, as of March 2019, Japan had concluded (either signed or brought into force) investment agreements covering 76 states/regions in total. In the case of Germany, China, and the Republic of Korea, they have each brought into force more than 100 investment agreements, which may include plurilateral and multilateral ones. Nikkei Shinbun (March 27, 2019).

36 U.N. Doc. A/1891 (1951), p. 33, para. 265 (14). The General Assembly took note of this report and its conclusions. U.N. Doc. A/RES/503A(VI) (January 12, 1952), para. 1. See also Repertory of Practice of United Nations Organs, Vol. V (1945-1954), pp. 316-318.

37 Ibid., pp. 317-318, paras. 7 and 11. See also Toublanc, supra note 31, pp. 445-446.

38 Professor Stefan Talmon reads the report as "the Committee tasked the General Assembly to make sure that States are not subjected to legal liabilities under treaties or other international agreements" (emphasis added). Stefan Talmon, "The Legalizing and Legitimizing Function of UN General Assembly Resolutions," AJIL Unbound, Vol. 108 (2014), p. 126. This reading is rather doubtful, however, in view of the fact that the relevant part of the report also referred to the case of a "decision" by the Security 
Council, which, as a legally binding action, would not necessitate that the Council "make sure" as described above.

39 Yearbook of the International Law Commission, 1979, Vol. II, Pt. 2, p. 119 (Commentary on Article 30, para. 14). See also ibid., Vol. II, Pt. 1, pp. 43-44, paras. 92-93 (Eighth Report on State Responsibility by Roberto Ago). Professor Vera GowllandDebbas also points out that the UN practice corroborates the view that the concept of a recommendation having the effect of rendering an otherwise unlawful act lawful is "no longer a controversial issue." Gowlland-Debbas, supra note 26, p. 371.

40 Cf. Talmon, supra note 38, pp. 123-128.

41 The same practice, as outlined in the text, might be considered constituting "subsequent practice" as an element to be taken into account in interpreting Article 103, rather than practice as a component to create customary international law. However, the fact that the Collective Measures Committee did not mention Article 103 in its report, as well as the relevant discussion in the Committee, seems to support the understanding described in the text.

42 The applicant also lodged the complaint with the European Court of Human Rights. However, the Court did not explicitly opine on the issue of the applicability of Article 103 to a Security Council resolution authorizing States to act in a specific way. It avoided explicitly addressing the issue by choosing the interpretation of the resolution most in harmony with the requirements of the Convention. European Court of Human Rights, Case of Al-Jedda v. the United Kingdom (Application no. 27021/08), Grand Chamber, Judgment (July 7, 2011), paras. 89-92 and 97-109, especially paras. 102, 105 , and 109.

43 House of Lords, "R (on the application of Al-Jedda) (FC) (Appellant) v. Secretary of State for Defence (Respondent)," UKHL, Vol. 58 (2007), paras. 1-2 and 45-47.

44 U.N. Doc. S/RES/1546(2004) (June 8, 2004), para. 10, in which the Security Council "[d]ecide[d] that the multinational force shall have the authority to take all necessary measures to contribute to the maintenance of security and stability in Iraq in accordance with the letters annexed to this resolution expressing, inter alia, the Iraqi request for the continued presence of the multinational force and setting out its tasks."

45 House of Lords, supra note 43, paras. 30-39.

46 Ibid., para. 33; and Jochen Abr. Frowein and Nico Krisch, "Article 39," in Bruno Simma ed., The Charter of the United Nations, 2nd ed. (2002), p. 729. The judgment also referred to Goodrich, Hambro, and Simons eds., supra note 31, pp. 615-616; and Danesh Sarooshi, The United Nations and the Development of Collective Security (1999), pp. 150-151. See also Michael Wood, "Detention During International Military Operations," Revue de Droit Militaire et de Droit de la Guerre, Vol. 47, Nos. 1-2 (2008), pp. 139-161.

47 See Orakhelashvili, supra note 21, p. 782, MN 45. Cf. Christian Tomuschat, "R (on the Application of Al-Jedda) v. Secretary of State for Defence," Melbourne Journal of International Law, Vol. 9, No. 2 (2008), p. 401. Others who deny the applicability of Article 103 to non-legally binding Security Council resolutions include Combacau, supra note 22, p. 284; Toublanc, supra note 31, p. 446; and Paulus and Leiss, supra note 25, p. 2127.

48 Andrea Charron and Clara Portela, "The Relationship Between United Nations Sanctions and Regional Sanctions Regimes," in Thomas J. Biersteker, Sue E. Eckert, and Marcos Tourinho eds., Targeted Sanctions (2016), pp. 105-117.

49 See Chapter 6 of this book.

50 Charron and Portela, supra note 48, pp. 113-114.

51 For example, in 1991, Yugoslavia supported a UN arms embargo against it the Security Council meeting when the latter adopted Resolution 713 (1991) to impose "a general and complete embargo on all deliveries of weapons and military equipment to Yugoslavia.” U.N. Doc. S/PV.3009 (September 25, 1991), p. 17. In 1993, the 
constitutional Haitian government requested UN mandatory sanctions against the de facto authorities in Haiti, and the Security Council decided to do so in its Resolution 841 (1993). U.N. Docs. S/25958 (June 16, 1993); and S/RES/841(1993) (June 16, 1993), pre. para. 2, op. para. 3.

52 Articles on State Responsibility (ASR), Articles 49-53.

53 For other aspects of the legality of autonomous sanctions, see, e.g., U.N. Doc. A/ HRC/30/45 (August 10, 2015), para. 13.

54 The ASR includes the rules that represent customary international law, as well as those that belong to the progressive development of international law, as the ILC itself admits. See, e.g., ILC Commentary on Article 48, para. 12; and ILC Commentary on Article 56, para. 1. However, as the law in the relevant areas has been radically developing, it would be justifiable to make an examination here based on the ASR. See, e.g., Yearbook of the International Law Commission, 2000, Vol. I, p. 90, para. 21 (Crawford); and Yearbook of the International Law Commission, 2001, Vol. I, p. 50, para. 2 (Hafner).

55 ILC Commentary on Article 42, para. 6.

56 For an explanation of the notion of a "bilateralizable" obligation, see Christian J. Tams, Enforcing Obligations Erga Omnes in International Law (2005), pp. 45, 128-136; Claudia Annacker, "The Legal Régime of Erga Omnes Obligations in International Law," Austrian Journal of Public and International Law, Vol. 46, No. 2 (1994), p. 136; and Linos-Alexander Sicilianos, "The Classification of Obligations and the Multilateral Dimension of the Relations of International Responsibility," European Journal of International Law, Vol. 13, No. 5 (2002), p. 1133.

57 ILC Commentary on Article 42, para. 13. See also ILC Commentary on Article 42, para. 5.

58 Ibid., para. 13.

59 Ibid., para. 14.

60 Cf. Giorgio Gaja, "The Concept of an Injured State," in James Crawford, Alain Pellet, and Simon Olleson eds., The Law of International Responsibility (2010), p. 945.

61 ILC Commentary on Article 42, para.15.

62 CIJ Recueil 1970, p. 32, paras. 33-34.

63 See ILC Commentary on Article 48, paras. 7 and 9-10, covering both obligations erga omnes and erga omnes partes.

64 Gaja, supra note 60, p. 945; and Sahib Singh, "Non-Proliferation Law and Countermeasures," in Daniel H. Joyner and Marco Roscini eds., Non-proliferation Law as a Special Regime (2012), p. 218.

65 ILC Commentary on Article 42, para. 13; and ILC Commentary to Article 48, para. 7.

66 ILC Commentary on Article 48, para. 11.

67 Linos-Alexandre Sicilianos, "Countermeasures in Response to Grave Violations of Obligations Owed to the International Community," in Crawford, Pellet, and Olleson eds., supra note 60, p. 1145.

68 ILC Commentary on Article 54, para. 6.

$69 \mathrm{Ibid}$. See also ILC Commentary on Article 22, para. 6; and Elena Katselli Proukaki, The Problem of Enforcement in International Law (2010), p. 86.

70 "Declaration of the Russian Federation and the People's Republic of China on the Promotion of International Law" (June 25, 2016), para. 6.

71 In July 2018, Iran submitted a case to the ICJ in which it claimed that the United States decision in May 2018 to re-impose sanctions on Iran violated the 1955 Treaty of Amity, Economic Relations, and Consular Rights between the two States. See "Alleged Violations of the 1955 Treaty of Amity, Economic Relations, and Consular Rights, Request for the Indication of Provisional Measures," Order (October 3, 2018), paras. 1-23. 


\title{
2 United Nations and sanctions
}

\author{
Philippe Achilleas
}

\section{Introduction}

Any legal order implies the existence of a sanctions system to guarantee the respect of the law. In the international legal order, which is characterized by the principle of sovereignty, States have long implemented the sanctions system on a unilateral and decentralized basis. In the twentieth century, international law matured through the establishment of the League of Nations and later, the United Nations (UN). It appeared necessary to set up a centralized system that would require States to comply with international obligations in the context of collective action. With the creation of the UN, an international organization gained the power to impose international sanctions on States that do not comply with international law. States transferred the role of adopting sanctions to the UN. Regional organizations also rely on the UN to impose sanctions, at least initially. These organizations can intervene, but only after the authorization of the UN Security Council. However, UN action is limited to the areas of jurisdiction of the organization in the field of peace protection. The UN cannot sanction any violation of international law. Nevertheless, this institutional innovation represents a major legal advancement.

The Security Council is designated by the UN Charter as the central body responsible for the implementation of sanctions. The sanctions mechanism established by the UN Charter is based on Chapter VII, which talks about action with respect to threats to the peace, breaches of the peace, and acts of aggression. Under Chapter VII, sanctions represent a political response to the violation of international peace and not a legal response for the violation of international law. Even if the violation of the peace by a State represents a violation of Article 2 (4) of the UN Charter, sanctions cannot be analyzed in a judgment on the responsibility of States. UN sanctions adopted under Chapter VII have a specific purpose. They are intended to reinforce the decisions of the Security Council, which are adopted to maintain or restore peace, by causing the recipient to comply with them. The purpose of sanctions is to modify the behavior of a Member State that is threatening international peace and security ${ }^{1}$ and not to punish or otherwise exact retribution. ${ }^{2}$ 
The Security Council has another legal basis for imposing sanctions, namely Chapter XIV, Article 94, paragraph 2 of the UN Charter. By this provision, the International Court of Justice (ICJ) may allow the Security Council to take measures to ensure the enforcement of the decisions of the ICJ. ${ }^{3}$ The sanctions that the Security Council may impose in this respect are considered to be of a criminal nature, since the refusal to execute a judgment represents a criminal offense. ${ }^{4}$ Article 94 (2) was invoked in the AngloIranian Oil Co. case (United Kingdom v. Iran) decided on July 22, 1952. ${ }^{5}$ The ICJ then ruled that it had no jurisdiction to act in this case. The reference to Article 94, paragraph 2 of the UN Charter has remained very marginal in international practice. ${ }^{6}$

The UN can also adopt administrative sanctions for noncompliance with the obligations under the Charter. These may take the form of an expulsion from the UN based on Article 6 of the Charter. ${ }^{7}$ This is a measure of exceptional gravity that has never been implemented. The UN prefers to maintain the dialogue with a State that would violate, even seriously, the provisions of the Charter. Alternative sanctions that are less radical are preferable. Thus, the UN can impose suspension of the exercise of the rights and privileges of membership based on Article 5. ${ }^{8}$ Under Article 19, the UN may also impose the suspension of voting rights in the General Assembly if a State has arrears with payment for its contributions to the organization. ${ }^{9}$

This chapter will focus on measures taken under Chapter VII, which allows the Security Council to impose material sanctions. Chapter VII is the central element of the sanctions regime implemented by the UN. This article deals with both economic sanctions and military sanctions implemented in addition to economic sanctions or in the event of the failure of economic sanctions.

The sanctions mechanism based on Chapter VII has remained dormant for a long time because of the Cold War, before it was reactivated during the 1990s. The Security Council, freed from the East-West blockade, implemented numerous economic and military sanctions. However, the practice has often gone beyond the letter of the Charter while the effects on civilian populations have sometimes been brutal. In the face of criticism, the UN has tried to rationalize its sanctioning policy. The UN has thus sought to regulate the mechanism of activation of sanctions (Section I) better as well as to ensure the effective implementation of sanctions (Section II).

\section{Triggering of the UN sanctions mechanism}

The UN Charter gives the Security Council the responsibility to implement the sanctions system without organizing any countervailing powers. The sanctioning power is organized through a procedure established by the Charter whose sometimes imprecise wording leaves room for maneuvers in the Security Council's resolutions in their implementation. 


\section{The central role of the Security Council}

Chapter VII of the UN Charter gives the Security Council the primary responsibility for the implementation of international sanctions. As a consequence, the power of sanctions are implemented by a social organ. The action of the Security Council shall replace the individual actions of Member States of the UN. Thus, the social will shall impose itself on individual will. ${ }^{10}$

The clearly established role of the Security Council provides the sanctions system with institutional solidity that was lacking within the framework of the League of Nations. ${ }^{11}$ In the context of Article 16 of the League of Nations Covenant, the organs of the organization only had a secondary role to play in the findings of the violation of the Covenant. If a Member of the League instigated a war outside the assumptions provided for in the Covenant, the other members had to impose commercial or financial sanctions. In such cases, the Council had the duty to recommend effective military, naval, or air force measures that the members of the League were expected to severally contribute to through armed forces that would be used to protect the covenants of the League. Another weakness of the League of Nations Covenant was that it did not indicate who had the responsibility to determine the breach of the Covenant. In the silence of the text, the determination of the violation of the Covenant remained the responsibility of each State.

The actual role played by the Security Council is the consequence of the primary responsibility that the UN Charter assigns to this body in the field of international peace and security. Thus, as stated in Article 24 of the UN Charter:

In order to ensure prompt and effective action by the United Nations, its Members confer on the Security Council primary responsibility for the maintenance of international peace and security, and agree that in carrying out its duties under this responsibility the Security Council acts on their behalf.

The specific powers granted to the Security Council for the discharge of these duties are laid down especially in Chapter VII. The sanctioning power of the Security Council is based on the decision-making power conferred on it by Article 25 of the UN Charter.

The sanction power of the Security Council is exclusive. No other organ of the UN Charter has such power. While the UN General Assembly may adopt resolutions in Chapter VII situations, its action is limited to a power of recommendation. ${ }^{12}$ The General Assembly cannot impose sanctions. The General Assembly may, however, "strongly urge"13 or "request"14 the Security Council to act based on Chapter VII. However, the Security Council is free to determine whether to act or not. The sanctioning power of the Security Council is discretionary. Thus, the Security Council is free to determine whether an action or a situation is likely to lead to a sanction, if it must sanction, and if so, by what means. The Security Council also has the power to put an end to sanctions measures. However, the activation of Chapter VII by the Security Council is not entirely discretionary. The 
sanction power has to remain, at the very least, within the limits of the purposes and principles of the UN Charter. ${ }^{15}$

The sanctioning power of the Security Council is neither subject to the political control of the UN General Assembly nor to the jurisdictional review of the ICJ. ${ }^{16}$ However, some measures taken by certain States and the European Union pursuant to the decisions adopted by the Security Council have been the subject of an appeal. Several cases have sought to challenge the implementation by States of sanctions imposed by the Security Council. The cases mainly concerned sanctions against those who were suspected of participating in or financing acts of terrorism. Thus, both the European Court of Justice ${ }^{17}$ and the European Court of Human Rights ${ }^{18}$ have stressed that States and the European Union cannot disregard respect for fundamental rights while applying the decisions of the Security Council. In 2009, faced with criticism of the sanctions system targeting persons without real procedural guarantees, the Security Council decided to create an Office of the Ombudsperson, whose task is to receive requests from individuals concerned by the sanctions imposed in the fight against terrorism. ${ }^{19}$ Persons on the sanctions list are entitled to obtain information on the reasons for the measures taken against them and to file delisting petitions with the Ombudsperson, who then examines each case impartially and independently and then submits a report to the Sanctions Committee explaining the reasons for or against delisting.

The hyper-centralized model of the sanctions system nevertheless poses a problem for the work of the UN. Indeed because of the mode of adoption of Security Council resolutions, any veto raised by one of the five permanent members blocks the sanction system. Thus, the Security Council can never act against the interests of one of the five permanent members or their allies. This explains the weak nature of the sanctions mechanism, especially during the Cold War. This observation remains valid even today. The sanctions against Iraq following the invasion and occupation of Kuwait in 1990 remain exceptional in many respects. It is precisely when the Security Council cannot exercise its power of sanctions that States decide to act unilaterally. This then follows a set of decentralized sanctions and reactions by the targeted States that implement countermeasures by way of retaliatory action. Thus, the economic sanctions imposed by the US and the European Union on Russia in 2014 following the illegal annexation of Crimea gave rise to the adoption of countermeasures by Russia. The case of sanctions imposed by the Security Council, ${ }^{20}$ the US, and the European Union ${ }^{21}$ against Iran following the resumption of its military nuclear program shows another limitation to the Security Council's sanctioning powers. Despite the lifting of sanctions validated by an agreement signed in $2015^{22}$ and endorsed by the UN Security Council, ${ }^{23}$ the US administration, following the election of Donald Trump, decided to denounce the treaty and to impose unilateral sanctions in 2018.

\section{The procedure for implementing sanctions}

Chapter VII of the UN Charter establishes a procedure for the adoption of international sanctions. 
A preliminary question arises here. Before implementing the sanctions provided for in Chapter VII, must the Security Council have exhausted the means of peaceful settlement of disputes under Chapter VI? In other words, is the activation of sanctions a measure of last resort? This idea was emphasized by the General Assembly when it stated: "Sanctions should be resorted to only with the utmost caution, when other peaceful options provided by the Charter are inadequate." 24 The Security Council also debated this issue and welcomed it quite favorably. ${ }^{25}$ However, neither the General Assembly nor the Security Council has adopted a resolution to this effect.

To activate Chapter VII, the Security Council must follow the steps laid down in the Charter. Thus, when the Security Council, in accordance with Article 39 of the Charter, determines the existence of a threat to peace, a breach of the peace, or an act of aggression, it decides on the measures to be taken under Articles 41 and 42 to either maintain or restore international peace and security.

Article 39 triggers the sanction mechanism. The starting point is based on a finding by the Security Council of a threat to peace, a breach of peace, or an act of aggression. The three situations are classified according to their effects on peace, from the least serious to the most serious: first, the threat to the peace; second, the breach of the peace; and third, aggression.

In the absence of precise definitions provided by the UN Charter, it is possible to determine the scope of each of these three situations based on prior practice of the Security Council. First, the notion of peace is not limited to the absence of international armed conflict. In the modern sense of international law, peace requires the establishment of conditions for political, economic, and social development of States, including the protection of human rights. ${ }^{26}$ The UN General Assembly defined the term "aggression" in resolution 3314 (XXIX) which it adopted on December 14, 1974. ${ }^{27}$ The problem is that the Security Council is reluctant to name a situation as one of aggression ${ }^{28}$ and prefers to use closer expressions such as "acts of aggression," 29 "aggressive acts," 30 and "armed invasion" 31 instead. The concept of "breach of peace" refers to a less serious situation involving the use of force, but not necessarily armed force. It is a broader concept that refers to both an act and a situation. Even when the breach of peace results from an act of aggression, the Security Council may refer to it as a "breach of peace." 32 This more neutral expression is often chosen for diplomatic reasons. It allows the Security Council to avoid specifying the entity responsible for the aggression as the supreme actor against peace. ${ }^{33}$ The threat to peace is a broader notion of a current (not potential) danger to peace, whether military or not. The practice of the Security Council shows the application of the concept of threat to peace in many situations. As a result, the practice of the Security Council has facilitated an extension of the scope of situations that may lead to sanctions under Chapter VII: the right of people to self-determination, ${ }^{34}$ internal armed conflicts, ${ }^{35}$ proliferation of arms, ${ }^{36}$ violation of human rights, ${ }^{37}$ undermining democratic legitimacy, ${ }^{38}$ and terrorism. ${ }^{39}$ The adoption of Resolutions $1540(2004)^{40}$ and $887(2009)^{41}$ represent an autonomous basis for the imposition of sanctions for nonproliferation. Adopted under Chapter VII, these texts allow the Security Council to sanction States contributing to the proliferation of nuclear, chemical, and biological weapons and 
their means of delivery. The adoption of a specific regulatory framework with sanctions measures demonstrates the rather broad powers of the Security Council with respect to sanctions.

The finding of a threat to peace, a breach of peace, or an act of aggression paves the way for action. First, the Security Council can choose to act by either making a recommendation or taking its own decision. The decisive character of Security Council resolutions is an indispensable element for its sanctioning power. This decisive character is based on Article 25 of the UN Charter. Second, when the Security Council acts by deciding upon a course of action, it may take nonmilitary measures under Article 41 or measures involving the use of armed force under Article 42. The Security Council may also take provisional measures in accordance with Article 40 of the UN Charter.

\section{Implementation of sanctions}

Once Chapter VII is activated, the Security Council benefits from a range of actions to punish a State that has either threatened or has already violated the peace. These are of gradual application, with military intervention being the ultimate sanction, The implementation of sanctions is accompanied by special measures to make sanctions more effective.

\section{The typology of sanctions}

The UN can adopt two types of sanctions, namely those that do not involve the use of force and those that do, or military actions.

Article 41 of the UN Charter empowers the Security Council to impose sanctions that do not involve the use of force. These sanctions are of an economic nature. Article 41 was first applied to Southern Rhodesia. ${ }^{42}$ If the Security Council is free to choose measures to be adopted, Article 41 allows an embargo as a means of action. ${ }^{43}$ The Security Council adopted its first embargo in the case of Southern Rhodesia to put an end to the rebellion that struck the former British colony. ${ }^{4}$ The Security Council can impose a total embargo as it did in the case of Iraq following the invasion and occupation of Kuwait. The Security Council banned all imports and exports to or from Iraq and Kuwait. The request was addressed to all States, including nonmember States of the UN. ${ }^{45}$ In contrast to the total embargo, a selective embargo allows the Security Council to adjust the sanction to suit the situation. UN practice has also turned to sanctions against individuals. These take the form of prohibitions of traveling abroad, freezing of assets, or prohibition of trade with the persons concerned. The Security Council may directly target the head of State or Government responsible for a threat to peace, a breach of peace, or an act of aggression. ${ }^{46}$ It may also target any State-related person involved in an activity that threatens or violates the peace, irrespective of whether it is affiliated to a government or not. ${ }^{47}$ Furthermore, sanctions may target a nonstate entity such as private compagnies, banks, terrorist groups/persons, ${ }^{48}$ and the institutions that support them. ${ }^{49}$ 
There is a certain graduation in the implementation of sanctions ranging from lighter measures to more restrictive ones that may lead to a total embargo. Like Iraq, the Federal Republic of Yugoslavia (Serbia and Montenegro) was also subject to a comprehensive embargo to end the fighting in Bosnia-Herzegovina. It was gradually expanded to a very wide range of products and services. It initially targeted products to or from Yugoslavia, air traffic, financial transactions, and sports relations..$^{50}$ It then targeted the transit of several strategic products through Yugoslavia. The embargo was also extended to the transit of all goods and products through the Federal Republic of Yugoslavia and to almost all services as well. ${ }^{51}$ Finally, it concerned the freezing of all funds belonging to Yugoslav nationals, regardless of where they were. ${ }^{52}$ Embargo measures can also be lifted gradually. Thus, going back to the Iraq example, following the military intervention of the international coalition against Iraq, the embargo was eased.

If the Security Council considers the measures taken under Article 41 as inadequate or find that such measures have not produced the desired effects, they may, pursuant to Article 42, use armed force. Security Council action may include demonstrations, blockades, and other operations by air, sea, or land forces of the members of the UN. Although the Security Council has never invoked Article 42, ${ }^{53}$ it has authorized the use of force. The first use of force under the auspices of the UN concerned the Korean War of 1950, when the Security Council unanimously ${ }^{54}$ condemned the North Korean invasion of the Republic of Korea. ${ }^{55}$ The Security Council then entrusted the US with the command of an international force. ${ }^{56}$ Subsequently, during the Cold War, the Security Council was unable to enforce its power of coercive sanction because of the immoderate use of the right of veto by the five permanent members. The invasion, occupation, and annexation of Kuwait by Iraq also led to a spectacular activation of the Security Council's enforcement action. ${ }^{57}$ Since Iraq did not react to the embargoes imposed by the Security Coun$\mathrm{cil}^{58}{ }^{58}$ it issued an ultimatum. The Security Council authorized the use of force if Iraq did not evacuate Kuwait by January $15,1991 .{ }^{59}$ The military operation, called "Desert Storm," which took place from January 17 to February 28, 1991, led to the restoration of Kuwait's sovereignty. At the end of hostilities, the Security Council imposed very strict conditions on Iraq for peace, particularly with regard to nuclear, chemical, biological, and ballistic disarmament. ${ }^{60}$ Other military interventions in Kosovo in 1999, and Iraq in 2003, were undertaken in violation of the Charter. The Security Council did not authorize these military operations. The military intervention in Afghanistan in 2001, on the other hand, is considered to be based on the right to self-defense provided for in Article 51 of the Charter. ${ }^{61}$

In the face of criticism of the sanctions regime imposing a global embargo and causing collateral damage on civilian populations and third States, the UN has encouraged the introduction of smart or targeted sanctions. Targeted sanctions aim at concentrating their effects on the leaders and the political regimes concerned, as well as on the trade in products that are likely to support their actions while seeking to limit the effects on the civilian population. ${ }^{62}$ The $\mathrm{UN}$ has encouraged debate on improving the sanctions system. The Interlaken Process, initiated in Switzerland in 1998-99, brought together experts, nongovernmental organizations, and 
UN staff to discuss the issue of financial sanctions. ${ }^{63}$ The Bonn-Berlin process, organized in Germany in 1999-2000, focused on arms embargoes and travel bans. ${ }^{64}$ The third round of studies, known as the "Stockholm Process," was initiated by the Swedish Ministry of Foreign Affairs in November 2001. It focused on the issue of the application of sanctions in domestic law. ${ }^{65}$

Targeted sanctions are implemented particularly through selective embargo measures. The UN has opted for selective embargoes since the first sanctions imposed on Southern Rhodesia in 1966. The selective embargo allows the Security Council to adjust the sanction to suit the situation. UN practice reveals many examples of targeted sanctions, which concern the embargo on arms and related materials, ${ }^{66}$ financial sanctions (freezing foreign assets, restrictions on access to international financial markets, stopping any international transfer of payment to a State or other State or a targeted entity), ${ }^{67}$ and the restriction on travel and commercial flights ${ }^{68}$ as well as restrictions on trade in natural resources such as oil/ petrol products, ${ }^{69}$ diamonds, ${ }^{70}$ and round logs and timber products. ${ }^{71}$ Restrictions on people suspected of participating in or financially supporting international terrorism represent a particularly effective form of targeted sanctions. ${ }^{72}$ The Security Council has established a procedure for the listing and delisting of persons subject to sanctions as well as the grounds for such listing and delisting.

\section{Accompanying measures}

The UN has established procedures to prevent the collateral effects of the sanctions being imposed. The aim is to first limit the negative effects of sanctions on third States. This procedure is provided under Article 50 of the UN Charter. ${ }^{73}$ Interested States are invited to address their requests for assistance to the President of the Security Council, which will be dealt with either positively or negatively. Indeed, Article 50 does not open up a right to automatic assistance but rather for consultations toward access to possible assistance. ${ }^{74}$ Assistance can be technical, economic, financial, or humanitarian. The Security Council may also authorize exemptions from penalties or may extend commercial advantages. Article 50 of the UN Charter has been invoked since the first Security Council sanctions against Southern Rhodesia. ${ }^{75}$ The number of requests for assistance has been particularly high in relation with the sanctions imposed on Iraq following the invasion, occupation, and annexation of Kuwait. ${ }^{76}$ The introduction of targeted sanctions is also another measure to mitigate the unwanted effects caused to third parties.

Second, other measures aim to limit the collateral effects of sanctions on civilian populations. Thus, in order not to inflict suffering on the civilian populations of countries under UN sanction, a provision is made to facilitate the work of humanitarian agencies. It appeared necessary, for instance, to avoid banning imports that are required by local health industries and to devise a fast track for the processing of applications for exemptions for humanitarian activities. ${ }^{77}$ The effect of sanctions on civilian populations has been particularly violent in the case of the measures taken against Iraq after the violation of Kuwaiti sovereignty. The embargo has disrupted the provision of basic means of livelihood to the civilian 


\section{Philippe Achilleas}

population such as clean water, food, electricity, and medicines. Several thousand children have been collateral victims of these sanctions. The Security Council adopted the "oil-for-food" program, providing Iraq with another opportunity to sell oil to finance the purchase of humanitarian goods, alongside various other mandated UN activities concerning Iraq. ${ }^{78}$

Preassessment is another proposed measure aimed at limiting the impact of sanctions on civilian populations and third States. This measure was particularly encouraged by UN Secretary-General Boutros Ghali in his report on the 50th anniversary of the United Nations. ${ }^{79} \mathrm{~A}$ first application the preliminary assessment was made as part of the sanctions against Sudan. It led to the nonimplementation of a sanction targeting Sudanese aviation. ${ }^{80}$

From an institutional point of view, it has been a practice of the Security Council, since the sanctions against Southern Rhodesia, to set up committees to monitor the implementation of sanctions. Although not provided for in the UN Charter, the establishment of a committee is now inherent from the establishment of a sanctions regime ${ }^{81}$ Committees are subsidiary bodies of the Security Council established based on the decisions taken under Chapter VII. ${ }^{82}$ The committee ends when the sanctions for which it was created are removed. As of January 1, 2019, 14 committees are in operation, ${ }^{83}$ while 16 committees have stopped functioning. The committees are composed of the members of the Security Council. The committees have several missions, such as supervising the measures taken by the States to apply the sanctions or to derogate from them, when such derogations are authorized. Some committees also have the task of identifying the people, property, or resources targeted by the sanctions ${ }^{84}$ The committees must also respond to violations of sanctions as well as requests from third States that are affected by the imposition of sanctions in accordance with Article 50 of the UN Charter. ${ }^{85}$ In addition, ten expert panels support the work of the sanctions committees in overseeing sanctions regimes. These groups of experts study the on-site effects of UN sanctions. They address their findings to the various sanctions committees and can make important contributions to the subsequent political decisions of the Security Council.

\section{Conclusion}

Over time, the implementation of the sanctions system established by the UN has revealed several flaws. First, the drafting of some provisions under Chapter VII in broad terms, which provide the basis for the sanctioning power, leaves the Security Council with a great margin of discretion. The Security Council decides to qualify a situation of threat to peace and breach of peace or to recognize an act of aggression. The Security Council also decides whether to impose a sanction or not. If it decides to deploy a sanction the Council chooses the measures to be taken. The action of the Security Council is jeopardized by the veto power of any or all of the five permanent Member States. These States can block a sanction targeting themselves or any other State. For example, the Security Council sanctioned Iraq for annexing Kuwait while it remained powerless against the 
annexation of Crimea by Russia. The excesses of the use of force in the absence of Security Council authorization in Kosovo in 1999 or Iraq in 2003 also demonstrate the limitations of the system. Further, collateral damages to the civilian populations are brought to light, including those caused by the UN. The feeling of arbitrariness and injustice that is spreading among States and populations is understandable. The credibility of the Security Council, but also of the UN, is at stake. The UN must react. The margin of maneuver is limited. The reform of the Security Council, as desired by developing countries, remains highly uncertain. Nothing can be expected from the permanent Member States. They will never give up the privilege granted to them by their right of veto. Thus, the UN must continue the efforts of enforcing transparency and the rationalization of sanctions measures. The introduction of smart sanctions is a significant step forward. Court judgments stressing upon the need for human rights in the implementation of sanctions were beneficial in prompting the UN to react, especially though the creation of the office of an Ombudsperson to hear the complaints of people who are victims of sanctions. Efforts to improve the sanctions mechanism will certainly not be sufficient in the current context of the rise of unilateralism. Despite these points of criticism, the UN sanctions mechanism is the most effective in the universal context to date.

\section{Notes}

1 Mohammed Bennouna, "Les sanctions économiques des Nations Unies [U.N. Economic Sanctions]," Collected Courses of the Hague Academy of International Law, Vol. 300 (2002), p. 24.

2 Supplement to the Agenda for Peace: Position paper of the Secretary-General on the Occasion of the 50th Anniversary of the United Nations, U.N. Doc. A/50/60, S/1995/1 (January 25, 1995), para. 66.

3 Article 94, para. 2, states: "If any party to a case fails to perform the obligations incumbent upon it under a judgment rendered by the Court, the other party may have recourse to the Security Council, which may, if it deems necessary, make recommendations or decide upon measures to be taken to give effect to the judgment."

4 Louis Cavaré, "Les sanctions dans le cadre de l'O.N.U [Sanctions Within the UN Framework]," Collected Courses of the Hague Academy of International Law, Vol. 80 (1952), p. 263; Geneviève Guyomar, "Article 94," in Jean-Pierre Cot, Mathias Forteau, and Alain Pellet eds., La Charte des Nations Unies, Commentaire article par article, Vol. 2 (2005), pp. 1887-1998.

5 ICJ, “Anglo-Iranian Oil Co. Case (United Kingdom v. Iran) (Jurisdiction)," ICJ Reports 1952, Judgment (July 22, 1952), p. 93.

6 For an analysis of section 94 (1), see: Cavaré, supra note 4, pp. 263-277.

7 Article 6 of the UN Charter states: "A Member of the United Nations which has persistently violated the Principles contained in the present Charter may be expelled from the Organization by the General Assembly upon the recommendation of the Security Council."

8 Article 5 of the UN Charter states: "A Member of the United Nations against which preventive or enforcement action has been taken by the Security Council may be suspended from the exercise of the rights and privileges of membership by the General Assembly upon the recommendation of the Security Council. The exercise of these rights and privileges may be restored by the Security Council." 


\section{Philippe Achilleas}

9 Article 19 of the UN Charter states: "A Member of the United Nations which is in arrears in the payment of its financial contributions to the Organization shall have no vote in the General Assembly if the amount of its arrears equals or exceeds the amount of the contributions due from it for the preceding two full years. The General Assembly may, nevertheless, permit such a Member to vote if it is satisfied that the failure to pay is due to conditions beyond the control of the Member."

10 Cavaré, supra note 4, p. 251.

11 On the comparison between the sanction system of the League of Nations and the UN, see Louis Cavaré, "Les Sanctions dans le Pacte de la S.d.N. et dans la Charte des N.U. [Sanctions Within the League of Nations and UN Frameworks]," Revue générale de droit international public (1950), pp. 647-674.

12 The UNGA resolution 377 (V) adopted on November 3, 1950, called Uniting for Peace states that in any cases where the Security Council because of the lack of unanimity among its five permanent members, fails to act as required to maintain international peace and security, the General Assembly shall consider the matter immediately and may issue any recommendations it deems necessary in order to restore international peace and security.

13 U.N. Doc. A/RES/ES-8/2 (1981) (September 14, 1981), Question of Namibia, para. 12.

14 U.N. Doc. A/RES/36/27 (1981) (November 13, 1981), Armed Israeli Aggression Against the Iraqi Nuclear Installations, para. 5.

15 International Criminal Tribunal for The Former Yugoslavia, Prosecutor v. Dusko Tadic a/k/a "Dule", Decision on the Defence Motion for Interlocutory Appeal on Jurisdiction, Tadić (IT-94-1) (October 2, 1995), para. 29.

16 The ICJ has clarified that it has no judicial review of decisions made by United Nations organs (ICJ, advisory opinion on "Legal Consequences for States of the Continued Presence of South Africa in Namibia (South West Africa) Notwithstanding Security Council Resolution 276 (1970)," ICJ Reports 1971, Advisory Opinion (June 21, 1971), para. 89.

17 CJEU, Judgment of the Court (Grand Chamber) of September 3, 2008, Yassin Abdullah Kadi and Al Barakaat International Foundation v. Council of the European Union and Commission of the European Communities, Joined cases C-402/05 P and C-415/05 P; CJEU, Judgment of the Court (Grand Chamber), July 18, 2013, European Commission and Others v. Yassin Abdullah Kadi, Joined Cases C-584/10 P, C-593/10 P and C-595/10 P-.

18 ECHR, Judgment of the Court (Grand Chamber), June 30, 2005, case of Bosphorus Hava Yollari Turizm Ve Ticaret Anonim Şirketi v. Ireland, application no. 45036/98; Case of Nada v. Switzerland, Judgment of the Court (Grand Chamber), September 12, 2012, application no. 10593/08.

19 U.N. Doc. S/RES/1904 (2009) (December 17, 2009), Threats to International Peace and Security Caused by Terrorist Acts.

20 U.N. Doc. S/RES/1737 (2006) (December 23, 2006), Non-proliferation.

21 E.U. Doc. Council Common Position 2007/140/CFSP of February 27, 2007, concerning restrictive measures against Iran, $O J$ L, Vol. 61 (February 28, 2007), p. 49.

22 Joint Comprehensive Plan of Action (JCPOA), Vienna, July 14, 2015, U.N. Doc. S/ RES/2231 (2015), Annex.

23 U.N. Doc. S/RES/2231 (2015) (July 20, 2015), Non-proliferation. The Agreement is published in the Annex of the Resolution.

24 U.N. Doc. A/RES/51/242 (1997) (September 15, 1997), Annex II, para. 1.

25 U.N. Doc. S/PV.4128 (May 17, 2000).

26 Pierre d'Argent, Jean D'Aspremont Lynden, Frédéric Dopagne, and Raphaël van Steenberghe, "Article 39," in Cot, Forteau, and Pellet eds., supra note 4, p. 1146. 
27 Article 1 states that: "Aggression is the use of armed force by a State against the sovereignty, territorial integrity or political independence of another State, or in any other manner inconsistent with the Charter of the United Nations, as set out in this Definition."

28 The Security Council has never referred to Resolution 3314 (XXIX) on the definition of aggression.

29 U.N. Doc. S/RES/387 (1976) (March 31, 1976), South Africa's Military Activities Against Angola; U.N. Doc. S/RES/411 (1977) (June 30, 1977), Southern Rhodesia's Military Activities Against Mozambique.

30 U.N. Doc. S/RES/667 (1990) (September 16, 1990), Iraq-Kuwait.

31 U.N. Doc. S/RES/428 (1978) (May 6, 1978), Angola-South Africa.

32 U.N. Doc. S/RES/660 (1990) (August 2, 1990), Iraq-Kuwait.

33 R.-J. Dupuy, "L'impossible agression: les Malouines entre l'O.N.U. et l'O.E.A [The Impossible Aggression: The Falklands Between U.N. and the O.E.A]," Annuaire français de Droit international (1982), pp. 342-343.

34 U.N. Doc. S/RES/217 (1965) (November 20, 1965), Southern Rhodesia.

35 U.N. Doc. S/RES/2127 (2013) (December 5, 2013), Central African Republic.

36 U.N. Doc. S/RES/1874 (2009) (June 12, 2009), Democratic People's Republic of Korea.

37 U.N. Doc. S/RES/418 (1977) (November 4, 1977), South Africa.

38 U.N. Doc. S/RES/1132 (1997) (October 8, 1997), Sierra Leone.

39 U.N. Doc. S/RES/2368 (2017) (July 20, 2017), ISIL (Da'esh) and Al-Qaeda.

40 U.N. Doc. S/RES/1540 (2004) (April 28, 2004), Non-proliferation of Weapons of Mass Destruction.

41 U.N. Doc. S/RES/1887 (2009) (September 24, 2009), Maintenance of International Peace and Security: Nuclear Non-proliferation and Nuclear Disarmament.

42 U.N. Doc. S/RES/232 (1966) (December 16, 1966), South Rhodesia.

43 According to Article 41, sanctions measures "may include complete or partial interruption of economic relations and of rail, sea, air, postal, telegraphic, radio, and other means of communication, and the severance of diplomatic relations."

44 The Security Council decided that all Member States would prevent the importation of an asbestos, iron ore, chrome, pig-iron, sugar, tobacco, copper, and animal products that had originated in Southern Rhodesia. Additionally, the activities of any of their nationals designed to promote the export of these commodities or the importation of arms, ammunition of all types, military aircraft, military vehicles, and equipment and materials for the manufacture and maintenance of arms and ammunition along with a total embargo of oil and oil products, though an exception was made for contracts granted before this resolution (U.N. Doc. S/RES/232 (1966)).

45 U.N. Doc. S/RES/661 (1990) (August 6, 1990), Iraq-Kuwait.

46 In implementing sanctions against Liberia, the Security Council decided, among other measures, that all States take the necessary measures to prevent the entry into or transit through their territories of high-level members of the Government of Liberia and their spouses (U.N. Doc. S/RES/1343 (1991) (March 7, 2001), "The Situation in Liberia”).

47 Thus, as part of the sanctions against the Democratic Republic of Korea for the continuation of its military nuclear program, the list established and maintained pursuant to Security Council Resolution 1718 (2006) includes officials and scientists from nuclear and space technology governmental research centers.

48 The UN Resolution 1333 (2000) of December 19, 2000 (The Situation in Afghanistan), addressed the freezing of funds and other financial assets of Osama bin Laden.

49 Sanctions adopted pursuant to Security Council resolutions 1267 (1999), 1989 (2011) and 2253 (2015) targeting the ISIL and Al-Qaeda, imposed a series of restrictions on a multitude of entities supporting terrorism.

50 U.N. Doc. S/RES/757 (1992) (May 30, 1992), Bosnia and Herzegovina. 


\section{Philippe Achilleas}

51 U.N. Doc. S/RES/787 (1992) (November 16, 1992), Bosnia and Herzegovina.

52 U.N. Doc. S/RES/820 (1993) (April 17, 1993), Bosnia and Herzegovina.

53 Under the Charter system, according to Article 43, Member States were to make available to the Security Council the armed forces necessary for the maintenance of peace. This article has never been implemented. The question then arose as to whether the activation of Article 42 was related to the application of Article 43. See: P. Daillet, "Article 42," in Cot, Forteau, and Pellet eds., supra note 4, p. 1243 and following.

54 The Soviet Union boycotted Security Council meetings dating back to January 1950, arguing that the Taiwanese "Republic of China" and not the mainland "People's Republic of China" held a permanent seat in the UN Security Council. As a result, the USSR could not exercise its right of veto.

55 U.N. Doc. S/RES/83 (1950) (June 27, 1950), Complaint of Aggression Upon the Republic of Korea.

56 U.N. Doc. S/RES/84 (1950) (July 7, 1950), Complaint of Aggression Upon the Republic of Korea.

57 See: Joe Verhoeven, “États alliés ou Nations Unies? L'ONU face au conflit entre l'Irak et le Koweit [Allied States or United Nations? UN and Iraq-Kuwait Conflict]," Annuaire français de Droit international (1990), pp. 145-194.

58 U.N. Doc. S/RES/660 (1990) (August 2, 1990), Iraq-Kuwait; and Resolution 661 of August 6, 1990, Iraq-Kuwait.

59 U.N. Doc. S/RES/678 (1990) (November 29, 1990), Iraq-Kuwait.

60 U.N. Doc. S/RES/687 (1991) (April 3, 1991), Iraq-Kuwait.

61 The United States' reliance on self-defense against Afghanistan following the attacks of September 11, 2001, is questionable because the conditions for the implementation of self-defense were not met. Indeed, during the events of September 11, the US was not attacked by Afghanistan but by a terrorist group called Al Qaeda. Admittedly, Al Qaeda did expand its activities into Afghanistan with the indirect support of the Taliban regime.

62 Bennouna, supra note 1, p. 60.

63 Targeted Financial Sanctions: A Manual for Design and Implementation, the Swiss Confederation, United Nations Secretariat and the Watson Institute for International Studies, Bonn University, 2001.

64 Design and Implementation of Arms Embargos and Travel and Aviation Related Sanctions, Bonn International Center for Conversion (BICC), German Foreign Office and the United Nations Secretariat, 2001.

65 Peter Wallensteen, Carina Staibano, and Mikael Eriksson eds., Making Targeted Sanctions Effective: Guidelines for the Implementation of UN Policy Options - Results from the Stockholm Process on the Implementation Targeted Sanctions (2003), p. 146.

66 U.N. Doc. S/RES/733 (1992) (January 23, 1992), Somalia.

67 For example, concerning DPRK: Asset Freeze (U.N. Doc. S/RES/1718 (2006), U.N. Doc. S/RES/2270 (2016) and U.N. Doc. S/RES/2371 (2017)); Prevention of Provision of Financial Services (U.N. Doc. S/RES/1874 (2009) and U.N. Doc. S/RES/2270 (2016); No Cooperation with DPRK Banks (U.N. Doc. S/RES/2270 (2016) and U.N. Doc. S/RES/2321 (2016)).

68 U.N. Doc. S/RES/1970 (1996) (August 16, 1996), Letter dated January 9, 1996, from the Permanent Representative of Ethiopia to the United Nations addressed to the President of the Security Council concerning the extradition of the suspects who were wanted in the assassination attempt on the life of the President of the Arab Republic of Egypt in Addis Ababa.

69 U.N. Doc. S/RES/2397 (1997) (December 22, 2017), Non-proliferation/Democratic People's Republic of Korea.

70 U.N. Doc. S/RES/1173 (1998) (June 12, 1998), Angola.

71 U.N. Doc. S/RES/1478 (2003) (May 6, 2003), The situation in Liberia. 
72 In particular: U.N. Doc. S/RES/1267 (1999) (October 15, 1999), U.N. Doc. S/ RES/1333 (2000) (December 19, 2000), U.N. Doc. S/RES/1390 (2002) (January 16, 2002), The Situation in Afghanistan, and U.N. Doc. S/RES/1989 (2011) (June 17, 2011), Threats to international peace and security caused by terrorist acts.

73 Article 50 of the UN Charter States: "If preventive or enforcement measures against any state are taken by the Security Council, any other state, whether a Member of the United Nations or not, which finds itself confronted with special economic problems arising from the carrying out of those measures shall have the right to consult the Security Council with regard to a solution of those problems." The implementation of Article 50 of the Charter has been the subject of a comprehensive study by the UN General Secretary (U.N. Doc. A/48/573 and S/26705 (November 8, 1993)).

74 The UN General Assembly recommends that these consultations should start as soon as possible (U.N. Doc. A/RES/50/51 (January 29, 1996), Implementation of Charter Provisions related to assistance to third States affected by the application of Sanctions).

75 Several States talked about the difficulties they encountered because of the adoption of the Resolutions 232 (1966) dated December 16, 1966, and 253 (1968) of May 29, 1968. While the requests of Portugal and Malawi have not led to any specific action, the Security Council has asked Member States, the United Nations, and other United Nations agencies to provide assistance to Zambia (U.N. Doc. S/RES/253 (1968) and U.N. Doc. S/RES/329 (1973) of (March 10, 1973)). Mozambique also received assistance in the context of sanctions against Southern Rhodesia (U.N. Doc. S/RES/ 386 (1976) (March 17, 1976), and U.N. Doc. S/RES/411 (1977) (June 30, 1977)).

76 Following the adoption of the Resolution 661 (1990) of August 6, 1990, in the context of Article 50 of the Charter, the Security Council received communications from 21 States. The total losses of the Member States were estimated by them at more than \$30 billion (USD). The Security Council entrusted the Sanction Committee established by Resolution 661 (1990) with the task of examining requests for assistance and making recommendations to the President of the Security Council for appropriate action. Jordan, which was particularly affected by its geographical and economic proximity, was the subject of special measures (see: special report (U.N. Doc. S/21786) of September 18, 1990, and a letter of October 22, 1990, from the Secretary-General addressed to the President of the Security Council (U.N. Doc. S/21938)). The Security Council Committee has also adopted a series of recommendations with regard to the other 20 States (see: letters of December 19 and 21, 1990, and March 19, 1991, from the Chairman of the Committee addressed to the President of the Security Council (U.N. Doc. S/22021 and Add.1 and 2)).

77 See in particular: D.L. Tehindrazanarivelo, Les sanctions des Nations unies et leurs effets secondaires [UN Sanctions and Their Collateral Effects], (2004), published on OpenEdition Books, September 1, 2014, available at $<\mathrm{https}$ ://books.openedition.org/ iheid/1508> (accessed January 4, 2019).

78 U.N. Doc. S/RES/986 (April 14, 1995), Authorization to permit the import of petroleum and petroleum products originating in Iraq, as a temporary measure to provide for humanitarian needs of the Iraqi people. The program, as established by the Security Council, is intended to be a "temporary measure to provide for the humanitarian needs of the Iraqi people, until the fulfillment by Iraq of the relevant Security Council resolutions, including notably resolution 687 (1991) of 3 April 1991".

79 U.N. Doc. A/50/60-S/1995/1 (January 3, 1995), Supplement to an agenda for peace: Position Paper of the Secretary-General on the occasion of the fiftieth anniversary of the United Nations, para. $75 \mathrm{c}$.

80 In 1996, the Security Council decided that all States will deny authorization to take off, land, or fly over their territory to any aircraft linked to Sudan Airways or the Sudanese public authorities (U.N. Doc. S/RES/1070 (1996) (August 16, 1996)). Before the application of the sanction, the Security Council sent a mission to Sudan to assess 


\section{Philippe Achilleas}

the potential humanitarian consequences of the sanction on the aviation. The report of this mission, submitted on February 20, 1997, concluded that the measure decided could affect vaccination, drug distribution, and food production programs The sanction on aviation could also jeopardize the work of humanitarian organizations operating in Sudan (UN, Department of Humanitarian Affairs, "Note from the Department of Humanitarian Affairs Concerning the Possible Humanitarian Impact of the International Flight Ban Decided in Security Council Resolution 1070 (1996)," February 20, 1997). Following this report, the Security Council decided not to apply this sanction.

81 No committee was created in the case sanctions against Sudan in 1996. The members of the Security Council could not agree on the modalities for the application of the air embargo provided for in Resolution 1070 (1996), so this sanction has never been applied.

82 In general, the committee is established under the resolution imposing sanctions (see U.N. Doc. S/RES/661 (Iraq), U.N. Doc. S/RES/748 (Libya), U.N. Doc. S/RES/841 (Haiti), U.N. Doc. S/RES/864 (Angola), U.N. Doc. S/RES/918 (Rwanda), U.N. Doc. S/RES/1132 (Sierra Leone), U.N. Doc. S/RES/2140 (Yemen)). However, the creation may occur after the adoption of the sanctions themselves (in the case of Somalia, the sanctions were adopted by the Resolution 733 (1992) of January 23, 1992, and the committee was established by Resolution 751 (1992) of April 24, 1992).

83 The sanctioning committees in activity were created by the following resolutions: U.N. Doc. S/RES/751 (1992) concerning Somalia; U.N. Doc. S/RES/1267 (1999), 1989 (2011) and 2253 (2015) concerning ISIL (Da'esh), Al-Qaida and associated individuals, groups, undertakings and entities; U.N. Doc. S/RES/1518 (2003) concerning Iraq; U.N. Doc. S/RES/1533 (2004) concerning the Democratic Republic of the Congo; U.N. Doc. S/RES/1591 (2005) concerning the Sudan; U.N. Doc. S/RES/1636 (2005) concerning events in Lebanon; U.N. Doc. S/RES/1718 (2006) concerning DPRK; U.N. Doc. S/RES/1970 (2011) concerning Libya; U.N. Doc. S/RES/1988 (2011) concerning the Taliban; U.N. Doc. S/RES/2048 (2012) concerning Guinea-Bissau; U.N. Doc. S/ RES/2127 (2013) concerning the Central African Republic; U.N. Doc. S/RES/2140 (2014) concerning Yemen; U.N. Doc. S/RES/2206 (2015) concerning South Sudan; and U.N. Doc. S/RES/2374 (2017) concerning Mali.

84 Under Resolution 1718 (2006), the Sanctions Committee has listed persons or entities engaging in or providing support for the DPRK's prohibited programs or by persons or entities acting on their behalf or at their direction could be designated, including their family members of such persons, for the travel ban. This was expanded under Resolution 2087 (2013), including the criteria of individuals and entities that have assisted the evasion of sanctions or in violating the provisions of Resolutions 1718 and 1874.

85 For a comprehensive article on the practice of UN Sanctions Committees, see François Alabrune, "La pratique des comités des sanctions du Conseil de sécurité depuis 1990 [The Practice of Security Council Sanctions Committees Since 1990]," Annuaire français de Droit international (1999), pp. 226-279. 


\title{
3 Human rights implications of sanctions
}

\author{
Pierre-Emmanuel Dupont
}

\section{Introduction}

At its 73th session (2018), the UN General Assembly reiterated its previous calls on the international community to refrain from using "unilateral coercive measures," a term used to refer mainly to economic sanctions not authorized by the UN Security Council. ${ }^{1}$ The Assembly adopted a resolution calling on

all States to cease adopting or implementing any unilateral measures not in accordance with international law, international humanitarian law, the Charter of the United Nations and the norms and principles governing peaceful relations among States, in particular those of a coercive nature, with all their extraterritorial effects, which create obstacles to trade relations among States, thus impeding the full realization of the rights set forth in the Universal Declaration of Human Rights and other international human rights instruments, in particular the right of individuals and peoples to development. ${ }^{2}$

The General Assembly therefore added to a long series of similar resolutions it adopted over the years, ${ }^{3}$ that denounce the impact of economic sanctions on human rights and call on States to renounce the use of such measures. Resolutions rejecting the use of economic sanctions have also been regularly and consistently adopted for decades by the Human Rights Council ${ }^{4}$ as well as by regional organizations. ${ }^{5}$ Numerous States have issued statements along the same line. ${ }^{6}$ This convergence of views has given the impression that an emergent norm of customary international law prohibiting the use of economic sanctions might be in the process of crystallizing within the international community. ${ }^{7}$ This view has been challenged by other commentators, who argue that the relevant resolutions and statements do not satisfy the required criteria - as developed by international jurisprudence and doctrine - for establishing a new custom. ${ }^{8}$ The present writer is of the view that there is probably a minima a quasi-consensus of the international community, giving rise to a new norm of customary law, that at least those economic sanctions regimes which do not incorporate (and ensure) minimal regard vis-à-vis basic human rights (including, but not limited to, availability of judicial or quasi-judicial review and of effective mechanisms to ensure remedies 
and redress for victims of human rights violations arising for unlawful imposition of sanctions), as well as the requirements of proportionality and discrimination in terms of the intended targets, and appropriate humanitarian exemptions, are certainly unlawful under international law. This quasi-consensus was especially visible in particular upon the unanimous adoption by the UN General Assembly of the 2030 Agenda for Sustainable Development, according to which

States are strongly urged to refrain from promulgating and applying any unilateral economic, financial or trade measures not in accordance with international law and the Charter of the United Nations that impede the full achievement of economic and social development, particularly in developing countries. ${ }^{9}$

The present chapter starts with an attempt to identify the applicable law, through an overview of the various sets of rules of international law (including international human rights law) possibly relevant to the evaluation of international sanctions. Section II offers a review of the different human rights that are the most likely to be affected by economic sanctions, relying in particular on findings and pronouncements of UN human rights bodies and humanitarian agencies, and drawing on various case studies of country-specific and targeted sanctions regimes. Special emphasis will be made on the findings of the UN Special Rapporteur on the negative impact of unilateral coercive measures on the enjoyment of human rights, appointed by the Human Rights Council in 2014. ${ }^{10}$ Section III turns to the initiatives taken and efforts made within the UN system as well as in the European Union to better take into consideration human rights concerns when designing and implementing sanctions, particularly in order to ensure the availability to all those targeted by sanctions of effective judicial or other remedies, including compensation for harm resulting from sanctions. Finally Section IV addresses the controversial question of the existence (and extent) of extraterritorial human rights obligations of States (and possibly international organizations) when imposing sanctions, that may be seen as flowing from the International Covenant on Economic, Social and Cultural Rights (ICESCR) and possibly from other human rights instruments.

\section{Overview of the applicable law: Human rights norms and instruments relevant to the human rights evaluation of sanctions}

Rules that may possibly apply to economic sanctions are found in a number of international instruments and areas of international law. First and foremost, the Charter of the United Nations and the foundational global human rights covenants formulate certain such rules that are of relevance to the practice of economic sanctions. This section examines Charter-based relevant rules, before turning to certain rules embodied in multilateral human rights instruments (especially the prohibition of discrimination). Finally, the question whether international humanitarian 
law (the law of armed conflict) may be relevant to the evaluation of sanctions including possibly those used outside an armed conflict - will be considered.

\section{The UN charter}

The Charter contains a general commitment of the Members in its Article 55(c) to promote "universal respect for, and observance of, human rights and fundamental freedoms for all without distinction as to race, sex, language, or religion." This explicit reference to the centrality of human rights in the work of the United Nations, also apparent in the preamble of the Charter, is not unrelated to the provision of Article 2(4), which sets out an undertaking to "refrain in their international relations from the threat or use of force against the territorial integrity or political independence of any state, or in any other manner inconsistent with the Purposes of the United Nations." There is a close interconnection between, on the one hand, the prohibition of intervention as formulated inter alia in Article 2(4) of the Charter, and restated, e.g., in the Friendly Relations Declaration of $1970^{11}$, and the realm of human rights. More precisely, the prohibition of intervention (or the principle of nonintervention) is arguably a corollary of the right to selfdetermination, ${ }^{12}$ which is integral to basic human rights. ${ }^{13}$

The relevance of the obligation in Article 2(4) to the practice of economic sanctions has been widely discussed since the early years of the UN. For example, as early as 1950, during the consideration by the International Law Commission (ILC) of the Draft Code of Offences against the Peace and Security of Mankind, it was proposed to add as a species of offence "against the peace and security," "[t]he fact of a State applying measures of psychological or economic coercion in respect of another State."14 Later on, during the discussion in the ILC on State responsibility, some members advocated the inclusion of a reference to "economic coercion" as a discrete "international crime" of States. Mr. Abdul Hakim Tabibi (Afghanistan) suggested that the relevant provision

be amended so as to refer to the prohibition of any resort to the threat or use of force not only the territorial integrity or the political independence of another State but also against its economic independence. The inclusion of that reference was essential because economic aggression was much more common than armed aggression, which was often inhibited by the fear of provoking a world war. Economic threats could also be much more effective than threats of armed intervention. ${ }^{15}$

Consensus on that proposition within the ILC was, however, impossible to reach. During the same meeting (1372nd meeting) of the ILC, Special Rapporteur Ago opposed the proposal put forward by Mr. Tabibi and stressed inter alia that the proposal to refer to "economic force" "had provoked a lively discussion at the United Nations Conference on the Law of Treaties, which had considered it in relation to coercion as a cause of the nullity of treaties." ${ }^{16}$ It is obvious that this stalemate within the international community, and the controversy regarding 
whether present-day international law contains a rule on the prohibition of economic and political coercion in international relations, ${ }^{17}$ has persisted to the present day. ${ }^{18}$

\section{Human rights instruments}

A number of other relevant rules can be found in multilateral and regional human rights treaties and covenants. The treaty-based commitments regarding each individual human right, i.e., the right to life, the right to health, the right to selfdetermination, the right to education, etc., are examined in turn in their relation to the practice of sanctions in Section 3 later. Here the present author wishes to draw attention to another basic rule of international human rights law having potential relevance to the evaluation of sanctions: the prohibition of discrimination. The issue of whether economic sanctions, especially comprehensive country-wide embargoes, could qualify as massive discriminatory measures has largely been overlooked until recent years, but it is now at the forefront, since the State of Qatar instituted contentious proceedings before the International Court of Justice ${ }^{19}$ based on alleged violations of the International Convention on the Elimination of All Forms of Racial Discrimination through the imposition of unilateral coercive measures on Qatar by several countries. On a general level, the point has been made by the UN Special Rapporteur on the negative impact of unilateral coercive measures on the enjoyment of human rights that the overwhelming majority of persons affected by comprehensive embargoes are not "blacklisted" individuals, persons engaged in illicit activities or in objectionable behavior, or even State officials targeted on the grounds of their belonging to the State apparatus of a targeted regime, but the civilian population at large, which bears no responsibility for the dispute. ${ }^{20}$ There is a strong legal argument that the sanctions have a discriminating effect on the basis of the country of residence, or nationality, of the targeted populations.

\section{International humanitarian law}

One last set of rules potentially relevant to the legal evaluation of economic sanctions is found in international humanitarian law (the law of armed conflict). There is a plausible argument that core rules of international humanitarian law may apply in cases of unilateral coercive measures affecting basic human rights or the civilian population at large, even in peacetime. ${ }^{21}$ For sure this argument may face conceptual difficulties, to the extent that the normative understanding of international humanitarian law is that it only governs State conduct during an "armed conflict.". 22

However, it has been argued that international humanitarian law "serves as the most appropriate paradigm through which economic sanctions should be governed, even when implemented outside the armed conflict context." ${ }^{23}$ The UN Special Rapporteur on unilateral coercive measures has expressed the view that, notwithstanding the legal intricacies and technicalities related to the scope of 
application of the Geneva Conventions and related instruments, "legal rights holders in target countries where the negative impact of such measures is particularly acute could be considered as in a war zone." 24

\section{Human rights consequences of economic sanctions}

The present section sets out a preliminary review of the various human rights that are the most vulnerable to unilateral coercive measures and refers to past or current instances of cases where economic sanctions imposed by the Security Council or unilaterally (either by regional organizations, groups of States, or by individual States), have actually (or arguably) impacted human rights. Due to space constraints, only the most basic rights are examined against that background, so that other rights potentially equally affected by sanctions, such as the freedom of religion, the freedom of movement, the right to seek asylum, the rights to privacy, reputation, and family rights, the right to access the court, the rights to a fair trial and to an effective remedy, and property rights, are set aside and will not be addressed as such in the present chapter. Before starting this overview, it is important to recall here that the Committee on Economic, Social and Cultural Rights (CESCR), in its General Comment 8, has declared that the inhabitants of a given country do not forfeit basic economic, social, and cultural rights by virtue of any determination that their leaders have violated norms of international peace and security. ${ }^{25}$ Although this comment seems to apply to sanctions adopted by the Security Council, it arguably applies equally to unilateral sanctions. ${ }^{26}$

\section{Right to life}

The right to life, as the most basic human right, has been labeled the human right most likely to be affected by economic sanctions. ${ }^{27}$ It is well established that this right not only encompasses a protection against arbitrary deprivation of life but also extends to socioeconomic aspects and incorporates positive obligations on States to take all necessary measures to secure this right. ${ }^{28}$

It is also commonly accepted that the right to life operates in an international setting and imposes obligations on States to respect and protect this right to the extent that their actions may affect the right to life of individuals in other jurisdictions. Based on these two assumptions, it can be argued that the effective realization of the right to life requires States implementing economic sanctions to refrain from deliberately enacting measures, the effect of which would be the deprivation of individuals of food, or worse, their subjection to hunger or starvation. ${ }^{29}$

Insofar as children are concerned, such obligation to respect and protect the right to life is corroborated by the relevant provisions of the Convention on the Rights of the Child. ${ }^{30}$ It has been noted with regard to UN Security Council sanctions, that these "should at the very least not result in denying children access to the basic goods and services essential to sustain life." ${ }^{31}$ There is every reason to expect that unilateral sanctions should comply with the same requirement. 
Instances of past sanctions against regimes entailing actual violations of the right to life include the UN Security Council sanctions resolutions on Iraq in the $1990 \mathrm{~s},{ }^{32}$ as well as other country-wide sanctions regimes. ${ }^{33}$ Also of relevance to the right to life is a finding of the ICJ in the provisional measures phase of the Alleged violations of the 1955 Treaty of Amity (Iran v. USA) case, where Iran sought to challenge the economic sanctions reimposed on it by the United States in 2018. The Court found, with respect to sanctions prohibiting access to aircraft spare parts by Iranian airliners, that

the measures adopted by the United States have the potential to endanger civil aviation safety in Iran and the lives of its users to the extent that they prevent Iranian airlines from acquiring spare parts and other necessary equipment, as well as from accessing associated services (including warranty, maintenance, repair services and safety-related inspections) necessary for civil aircraft. ${ }^{34}$

\section{Right to self-determination}

Article 1(1) common to the International Covenant on Civil and Political Rights and the International Covenant on Economic, Social and Cultural Rights recognizes the right of all peoples to self-determination and stresses that "by virtue of that right they freely determine their political status and freely pursue their economic, social and cultural development." Article 1(2) common to both Covenants provide that "in no case may a people be deprived of its own means of subsistence." It has been noted in that respect that the imposition of economic sanctions on a State "may raise special risks of depriving a people of its means of subsistence." ${ }^{35}$ The manner in which such risks may materialize in given cases, through interference with the various economic, social, and cultural rights, has been highlighted by the CESCR in its General Comment 8. ${ }^{36}$

Commentators of the ICESCR have observed that

it is plain that in a given case, universally imposed sanctions regimes, which are insufficiently tailored or targeted and which lack adequate humanitarian exemptions, could have the cumulative effect of depriving a population, or substantial sections of it, of their means of subsistence. ${ }^{37}$

Along the same line, it seems plausible to argue that

[u]nilateral economic sanctions (as opposed to multilateral UN measures under Chapter VII of the Charter) imposed by one State on another, to compel that State to change a particular political or economic policy, could amount to a prohibited intervention and a denial of self-determination. ${ }^{38}$

Respect of self-determination in that context is to be read in context with the rule precluding economic and political coercion, affirmed inter alia by the General Assembly in its Declaration on Friendly Relations among States (1970). ${ }^{39}$ 


\section{Right to development}

The right to development, as embodied in a number of international instruments and resolutions $s^{40}$, is especially vulnerable to economic sanctions. The Human Rights Council reaffirmed in 2014 that "unilateral coercive measures are a major obstacle to the implementation of the Declaration on the Right to Development." ${ }^{\text {"41 }}$ Indeed, it has been observed that

[t]he negative consequences [of economic sanctions] in the target country can include loss of jobs, higher consumer prices, economic stagnation, and, in the extreme, impoverishment and ill health. ... Sanctions can also readily escalate into retaliation and 'trade wars', even drawing in other countries, leading to further economic difficulties and threats to international stability. As noted, commercial relations with many different countries may be impaired, both in the short and long term. All of this can have damaging effects on the realization of the right to development. ${ }^{42}$

The actual adverse consequences of unilateral coercive measures on development have been examined in several studies. ${ }^{43}$ To quote only an example, reflecting on the case of the sanctions against Zimbabwe, the UN High Commissioner for Human Rights has stressed their impact in the following terms:

there seems little doubt that the existence of the sanctions regimes has, at the very least, acted as a serious disincentive to overseas banks and investors. It is also likely that the stigma of sanctions has limited certain imports and exports. Taken together, these and other unintended side-effects will in turn inevitably have had a negative impact on the economy at large, with possibly quite serious ramifications for the country's poorest and most vulnerable populations. ${ }^{44}$

\section{Right to an adequate standard of living, including food, clothing, housing, and medical care}

The OHCHR has noted that

[u]nilateral coercive measures that impinge on the provision of an adequate standard of living, including medical care, food, clothing and housing, would have an impact on the implementation of article 25, paragraph 1, of the Universal Declaration of Human Rights, and of articles 11 and 12 of the International Covenant on Economic, Social and Cultural Rights. ${ }^{45}$

Along the same line, the Committee on Economic, Social and Cultural Rights, in its General Comment 12 on the right to adequate food, has stated, with reference to Article 11 of the Covenant, that

States Parties should refrain at all times from food embargoes or similar measures which endanger conditions for food production and access to food 
in other countries. Food should never be used as an instrument of political or economic pressure. ${ }^{46}$

Actual examples of such adverse impacts of unilateral coercive measures on the enjoyment of the right to an adequate standard of living may be found in various reports and studies. For example, regarding Cuba, the Personal Representative of the UN High Commissioner for Human Rights stated that

[t]he restrictions imposed by the embargo help to deprive Cuba of vital access to medicines, new scientific and medical technology, food, chemical water treatment and electricity. ${ }^{47}$

Germane to the right to an adequate standard of living is the right to water, according to the Human Rights Council. ${ }^{48}$ The vulnerability of the right to water to economic sanctions has been highlighted by the CESCR, when it called States parties to the ICESCR to refrain from imposing embargoes or similar measures that prevent the supply of water, as well as the goods and services essential for securing the right to water. ${ }^{49}$ As an actual example of such effects, one may refer to the UN Human Rights Committee's finding in 2010 that the effects of the blockade on the civilian population in the Gaza Strip included inter alia "restrictions on the access to sufficient drinking water and adequate sanitation."50

\section{Right to health}

The right to health is probably one of the most likely to be affected by sanctions, as was stated in a series of resolutions of UN organs and bodies, including the General Assembly ${ }^{51}$ and the Human Rights Council, ${ }^{52}$ as well as in UN reports. ${ }^{53}$ For instance, in 2000 the Sub-commission on Human Rights cited "deteriorating humanitarian conditions in countries which have been affected by heavy sanctions, including embargoes, particularly as evidenced in increasing rates of child malnutrition and mortality and deteriorating health indicators." 54

The actual impact on the enjoyment of the right to health of the decade-long embargo on Iraq has been widely documented. ${ }^{55}$ Studies focusing on other countries targeted by economic sanctions point to the same negative effects on the right to health, mostly either through shortage of medical supplies or through damage to the health infrastructure. ${ }^{56}$ The CESCR, in its General Comment 8 , mentioned that sanctions, here taken to refer to unilateral coercive measures, may "severely interfere with the functioning of basic health . . . systems." More specifically, the same committee, in General Comment 14 on the right to health, urged States parties to the Covenant to

refrain at all times from imposing embargoes or similar measures restricting the supply of another State with adequate medicines and medical equipment. Restrictions on such goods should never be used as an instrument of political and economic pressure. ${ }^{57}$ 
In that context, it is important to recall that the right to health is commonly understood as containing an obligation on States to respect the right to health, which in turn is assumed to impose a legal obligation on States to take reasonable measures to ensure that the consequences of their actions are not harmful to the health of persons in jurisdictions other than their own. ${ }^{58}$ In other words, as explained by the UN Special Rapporteur on the Right to Health, "international assistance and cooperation require that all those [States] in a position to assist should, first, refrain from acts that make it more difficult for the poor to realise their right to health." 59

The precise nature and extent of this obligation to refrain from any action that would be harmful to the health of persons in other jurisdictions is still subject to some controversy. ${ }^{60}$ However, it appears reasonable to assume that the obligations of States to respect, at the very least, the "core content" of the right to health extend to a requirement to structure any sanctions regime "in a way that does not undermine the availability and accessibility of basic health facilities, goods and services on a non-discriminatory basis. ${ }^{" 61}$ In its order on provisional measures in the Alleged violations of the 1955 Treaty of Amity (Iran v. USA) case, the ICJ has found that

restrictions on the importation and purchase of goods required for humanitarian needs, such as foodstuffs and medicines, including life-saving medicines, treatment for chronic disease or preventive care, and medical equipment may have a serious detrimental impact on the health and lives of individuals on the territory of Iran. ${ }^{62}$

\section{Right to education}

The CESCR has noted in its General Comment 8 that economic sanctions may severely interfere with the functioning of the education system, ${ }^{63}$ thus impacting the right to education as guaranteed in Article 13 of the Covenant on Economic, Social and Cultural Rights.

The actual effects of the UN embargo on Iraq in the 1990s on the enjoyment of the right to education have been comprehensively studied. ${ }^{64}$ Another, more recent, documented example, is the case of the sanctions adopted against Iran (before the nuclear deal of 2015), where the decrease of access of Iranian women to higher education as a consequence of economic sanctions was witnessed in a report issued by the Advisory Committee of the Human Rights Council. ${ }^{65}$

\section{Reforms in the UN and EU practice of sanctions}

\section{The United Nations system}

In 1995, the five permanent members of the UN Security Council issued a policy statement stating that "future sanctions regime[s] should be directed to minimize unintended adverse side-effects of sanctions on the most vulnerable segments of 
targeted countries" and "the short- and long-term humanitarian consequences of sanctions" should be factored into designing such programs. ${ }^{66}$ In line with such statements, there is a pattern of Council action supporting the idea that the Council accepts that it is bound to observe humanitarian limits in its application of sanctions. ${ }^{67}$ In his 1999 report on the work of the United Nations, then UN SecretaryGeneral Kofi Annan stressed on a related note that:

[i]t is increasingly accepted that the design and implementation of sanctions mandated by the Security Council need to be improved, and their humanitarian costs to civilian populations reduced as far as possible. This can be achieved by more selective targeting of sanctions, as proponents of so-called "smart sanctions" have urged, or by incorporating appropriate and carefully thought through humanitarian exceptions directly in Security Council resolutions. ${ }^{68}$

The UN system therefore decided to renounce the use of comprehensive sanctions, and to focus on "targeted" sanctions, which has largely addressed concerns about unintended human rights consequences. ${ }^{69}$ Over time, assessments and preassessments have been conducted, and there has been a steady move toward standardizing humanitarian exemptions. However, further steps have been recently called for by States advocating that all UN sanctions regimes and measures should be periodically reviewed by the Security Council, which should also conduct periodic reviews of listed individuals and entities in all sanctions regimes to ensure that information is up to date and that the listings remain appropriate. ${ }^{70}$

As far as remedies for victims (and forums available to seek redress) are concerned, there are within the UN system certain options, under the form of several treaty-based mechanisms potentially allowing individuals to pursue claims against States based on violations of human rights. ${ }^{71}$ Some of these mechanisms are a priori relevant to the situation of persons whose human rights have been infringed by economic sanctions. It must however be emphasized that in certain cases such mechanisms may be unavailable due to a failure from certain States having recourse to economic sanctions to ratify the relevant human rights treaty or protocol.

It can be assumed that individuals adversely affected in their enjoyment of human rights by unilateral sanctions could lodge complaints against the targeting State(s) before the Human Rights Committees established by the First Optional Protocol to the International Covenant on Civil and Political Rights (ICCPR) and the International Covenant on Economic, Social and Cultural Rights (ICESCR), respectively, to the extent that the targeting State(s) have ratified the Optional Protocol(s). Each committee may consider individual communications alleging violations of any of the rights set forth in the Covenant concerned. ${ }^{72}$ In the case of economic sanctions, this may raise jurisdictional issues insofar as the persons concerned would arguably not be "under the jurisdiction" of the targeting State, which leads to the question of extraterritorial applicability of the Optional Protocols. The issue is dealt with in Section IV of the present chapter. Be it as it may, 
it is noteworthy that although decisions of the committees are not legally binding, these may call the State found in violation of its obligations under the Covenant(s) to submit information in its subsequent periodic report on any measures it has taken to respond to the committee's views or recommendations. ${ }^{73}$

The role of the Special Procedures of the UN Human Rights Council in the consideration of human rights violations linked to the imposition of sanctions is also to be highlighted. The UN Special Rapporteur on the negative impact of unilateral coercive measures on the enjoyment of human rights, appointed in 2014, is empowered to act on individual cases by sending communications to the State(s) concerned to bring violations and abuses to its attention. Other special procedures, to their extent that their mandate is of relevance to some aspects of infringements of human rights related to the imposition of sanctions, may also be addressees of such communications. The Human Rights Council Complaint Procedure, as another forum to address consistent patterns of gross and reliably attested violations of all human rights, may also be considered of relevance in certain cases of sanctions regimes.

\section{The European Union}

The EU in its sanctions practice, implemented within the legal framework of the EU's Common Foreign and Security Policy (CFSP),${ }^{74}$ has over time developed guidelines to ensure the existence of an appropriate legal basis for the imposition of each given sanctions measures and to ensure the availability of effective humanitarian exemptions and judicial forums for affected persons to seek remedies and redress. The Council of the European Union has underlined its principled position that

the introduction and implementation of restrictive measures must always be in accordance with international law. They must respect human rights and fundamental freedoms, in particular due process and the right to an effective remedy. The measures imposed must always be proportionate to their objective. ${ }^{75}$

The Council has also emphasized the importance

that the legal instruments on financial restrictions, restrictions on admission and other restrictive measures make provision for appropriate exemptions to take account of in particular basic needs of targeted persons, legal fees, extraordinary expenses or, where applicable, humanitarian needs or international obligations, including as host nations of international organisations or the OSCE, with regard to the various restrictive measures taken. ${ }^{76}$

European Union sanctions are now also routinely kept under regular review to assess their impact and effectiveness. ${ }^{77}$

As far as remedies and redress are concerned, EU sanctions are subject in principle to full-scope judicial review before the EU General Court and on appeal 
before the European Court of Justice (ECJ). This applies equally to measures taken in implementation of UN Security Council resolutions under Chapter VII of the UN Charter and to "autonomous" EU measures, as was made clear in the famous Kadi case. ${ }^{78}$ The courts of the EU have developed over time a rich jurisprudence in cases brought by individuals or entities subject to sanctions, and in some cases the applicants have actually obtained their "de-listing," even if the proportion of successful challenges remains limited. There are dozens of new actions for annulment brought each year before the EU General Court. ${ }^{79}$ It is not unsafe to assume that the evolution of EU sanctions toward better taking into consideration of human rights standards and due process has been driven to a large extent by the jurisprudence of the EU Court's ruling on appeals by targeted parties.

The central provision governing direct actions for judicial review of European Union measures before the EU General Court and the European Court of Justice (ECJ) is Article 263 of the Treaty on the Functioning of the European Union (TFEU), which allows natural or legal persons to seek the review of the legality of acts of EU organs. ${ }^{80} \mathrm{It}$ is expressly provided for the competence of the EU General Court and the ECJ to review the legality of decisions providing for restrictive measures against natural and legal persons adopted on the basis of the Union's CFSP. EU sanctions may also be challenged indirectly, through references for a preliminary ruling under Article $267 \mathrm{TFEU}$, when an issue of interpretation of EU sanctions legislation arises in proceedings before a national judge of one of the 27 EU Member States.

Regarding the various grounds for review, it is to be noted that an EU restrictive measure may be annulled if the EU institution concerned is found to have "misused its power." This may be an abuse of power where a power is used for purposes other than that for which it was granted. Another ground for annulment is a manifest error of assessment. ${ }^{81}$ This requires EU measures to be substantiated by the evidence provided, and for that evidence to be accurate, reliable, consistent, and sufficiently complete. The third heading of review is "rights of process." These include the right to know the reasons for a legal measure, the rights to a hearing where one's interests are restricted, protection of one's rights of defense in the case of possible sanction, and, finally, the right to administration of one's affairs with due care by the EU institutions. The final heading of review is infringement of the EU Treaties or any rule of law relating to its application. This includes breach of any substantive provision of EU law and violation of fundamental rights. It also encompasses EU legal principles developed by the Court of Justice, namely nondiscrimination, proportionality, legal certainty, and protection of legitimate expectations. ${ }^{82}$

The judicial review exercised by the courts of the EU does not extend, however, to a review of the general motivations underlying the political decision to implement a sanctions regime or blacklist a person. This means that EU political institutions "have broad discretion in defining the general criteria which are to determine the scope of targeted persons, entities and activities." ${ }^{83}$ Therefore, it appears that the courts of the EU do not commonly, and are unlikely to, address the legality of EU sanctions from the viewpoint of their compliance with international law, ${ }^{84}$ 
whilst such compliance is put forward by the EU Council itself when it asserts that "the introduction and implementation of restrictive measures must always be in accordance with international law." ${ }^{\circ 5}$

Even if no precedent exists, it seems uncontroversial that an action for annulment of EU restrictive measures against a specific country may also be brought before the EU courts by the government of a targeted State. It seems indeed established that a third State (non-EU-member) can bring proceedings before the General Court/ECJ under Article 263 TFEU, provided that the State concerned meets the standing requirements set in that article, i.e., that the measure complained of is of "direct concern" to it. ${ }^{86}$

What remains unsettled is whether individuals or entities found to have been unlawfully subject to EU sanctions could be awarded damages before EU courts. The possibility of such compensation is provided for by Article $268 \mathrm{TFEU}$, under which private parties may bring actions for damages before the General Court alleging a noncontractual liability of the EU ${ }^{87}$ There are, however, very few cases where EU courts have granted damages to victims of wrongful EU sanctions. ${ }^{88}$

\section{Do States and international organizations have extraterritorial obligations in respect of sanctions?}

The question is still debated whether States' obligations under the Covenant on Economic, Social and Cultural Rights extend extraterritorially

to the point at which a state imposing sanctions might be held responsible for any consequential deprivation (of the right to food or health care for example) even if the sanctioning state exercised no formal jurisdiction or control over the population concerned. ${ }^{89}$

Some commentators have stressed that strong and convergent legal arguments might support a positive answer to that question. First, is has been observed that

it is now widely agreed that human rights treaties may, in principle, impose on States parties obligations not only when they adopt measures applicable on their own territory, but also extraterritorial obligations, which may include positive obligations going insofar as the State can influence situations located abroad. ${ }^{90}$

It seems actually difficult to deny that sanctions come within the category of situations where States "can influence situations located abroad." Al Also, it is now well established that the effective realization of, and respect for, human rights implies the existence of extraterritorial obligations of States when enacting unilateral coercive measures; the Human Rights Committee found in that respect that

[i]t would be unconscionable to so interpret the responsibility under article 2 of the Covenant [on Civil and Political Rights] as to permit a State party to 
perpetrate violations of the Covenant on the territory of another State, which violations it could not perpetrate on its own territory. ${ }^{92}$

It can be deemed significant that the ICESCR does not contain territorial or jurisdictional limitations to its scope of application. ${ }^{93}$ Whereas Article 2(1) of the ICCPR sets out the obligation of States parties to respect and ensure the rights of all individuals "within its territory and subject to its jurisdiction', the parallel provision in Article 2(1) of the ICESCR avoids any reference to "jurisdiction" or "territory."94 Furthermore, the ICESCR, in a language that has no equivalent in the corresponding provision of the ICCPR, imposes an obligation upon all States to "take steps, individually and through international assistance and cooperation" with a view to achieving the full realization of the rights recognized on a progressive basis. ${ }^{95}$ This clearly implies that States parties assume certain obligations of an external or international nature. ${ }^{96}$ This in turn supports the view that the ICESCR sets forth certain extraterritorial obligations for State parties, i.e., in respect of individuals in third States. ${ }^{97}$

Another plausible argument is that the concept of "jurisdiction," as a criterion (alternative to "territory") for the applicability of human rights legal obligations of States, has been extended over time to address satisfactorily situations where a restrictive application of the territorial or jurisdictional requirements in the relevant treaty would have prevented the application of the treaty. Thus, jurisdiction has been established with respect to "occupied" territory ${ }^{98}$ and to territory over which a State assumes some form of "effective control." 99 Taking these findings further, and applying these to situations where the measures complained of (i.e., sanctions) have extraterritorial effects by their very nature, it may be reasonably argued that a State imposing sanctions should incur liability for violations of human rights even if it does not exercise formal "jurisdiction" or "control" over the population or the territory targeted. ${ }^{100}$

Further, the affirmation of the existence of extraterritorial human rights obligations of States would be consonant with the customary international law rule that prohibits a State from allowing its territory to be used to cause damage on the territory of another State, a requirement that has gained particular relevance in international environmental law ${ }^{101}$ and may be deemed relevant to the field of protection of human rights. ${ }^{102}$ Also, arguments in favor of extraterritorial obligations under human rights treaties are fully consistent with the actual practice of the CESCR. General Comment No. 8 of the CESCR, already quoted, sets out certain obligations on "parties responsible for the imposition, maintenance or implementation of the sanctions," "whether it be the international community, an international or regional organization, or a State or group of States." 103 Among these obligations flowing "from the recognition of economic, social and cultural human rights," the Committee identified the obligation to respond "to any disproportionate suffering experienced by vulnerable groups within the targeted country."104 The CESCR expressed the view that

when an external party takes upon itself even partial responsibility for the situation within a country (whether under Chapter VII of the Charter or 
otherwise), it also unavoidably assumes a responsibility to do all within its powers to protect the economic, social and cultural rights of the affected population. ${ }^{105}$

This implies that a State imposing sanctions, insofar as it practically assumes even "partial responsibility for the situation within" the targeted country, is also necessarily and ipso facto under an obligation to protect the economic, social, and cultural rights of the affected population.

Other findings of the CESCR point to the same direction. In its general comment on the right to the highest attainable standard of health, the committee emphasized that "States parties should refrain at all times from imposing embargoes or similar measures restricting the supply of another state with adequate medicines and medical equipment." 106 This position taken by the committee, it has been noted, "may be interpreted as an implicit recognition of extraterritorial human rights obligations" in the area of economic, social and cultural rights. ${ }^{107}$

As far as the Human Rights Committees established under the Optional Protocols to both the ICCPR and ICESCR are concerned, it has been noted that a jurisdictional issue may arise, since the Optional Protocols require that authors of communications be under the jurisdiction of the State responsible for the violation (which, again, must have ratified both the Covenant concerned and its Optional Protocol). It is unclear whether this requirement acts as a bar to the filing of a communication against States when they violate a protected right beyond their borders. ${ }^{108}$ It has been observed with respect to the Optional Protocol to the ICESCR that:

In practice, however, extraterritorial application under the Optional Protocol should not be ruled out. A number of scholars have suggested ways in which states may be bound by their obligations under the Covenant when acting extraterritorially. The jurisprudence of other international bodies, including the Human Rights Committee and the International Court of Justice, shows that it is possible to hold governments to account if they violate the fundamental rights of persons who live outside their borders. Regional bodies, such as the European Court of Human Rights, made analogous observations. The Committee on Economic, Social and Cultural Rights has itself considered extraterritoriality. In its General Comment 15 on the Right to Water, for example, it made clear that a state should not deprive another state of its capacity to guarantee the right to water of its residents, for example by diverting water courses in a border area.51 In its Concluding Observations on periodic reviews of states parties, the Committee has clearly indicated that jurisdiction includes 'any territory over which a State Party has geographical, functional or personal jurisdiction'. In light of the above, the Committee could chose to accept communications from individuals whose rights under the Covenant have been violated and who live outside the territory of the state party that they allege is responsible. ${ }^{109}$ 
It is therefore reasonable to assume that, in the case of unilateral sanctions, complaints against targeting State(s) brought by individuals nationals of (or residing in) other States may be admissible.

\section{Conclusion}

There have been in recent years significant developments within the UN system and outside of it (e.g. in the European Union), to better ensure respect for human rights in the imposition of economic sanctions, with mixed results. It may be deplored that the level of protection now commonly available to targets of UN or EU sanctions is not matched by an acceptable, even minimal, level of protection in cases of other "unilateral" sanctions. Most non-EU unilateral sanctions, especially those enacted by the main country user of sanctions, are imposed without any meaningful mechanism for judicial review, remedies and redress, or effective and functioning humanitarian exemptions, being in place. This means that entire countries and their populations under certain sanctions regimes are almost entirely (and effectively) deprived of any competent legal forum before which they could seek to obtain remedies and redress. ${ }^{110}$

The present author is also of the view that, beyond the relevance of certain human rights mechanisms and fora that could be used by victims of sanctionsrelated human rights violations, the general principles of State responsibility (and/ or the responsibility of international organizations as the case may be) may find application in cases of damage caused on a targeted country by the application of economic sanctions by State(s) (or international organizations). There is no reason to exclude the basic principle in Article 1 of the ILC Articles on State Responsibility, that "[e]very internationally wrongful act of a State entails the international responsibility of that State" 111 , in instances of wrongful acts of a State entailing damages to human rights of persons or populations of targeted countries. In relation to the international responsibility of a State for unlawful acts, it has even been observed that a State "is under the duty to control the activities of private persons within its State territory and the duty is no less applicable where the harm is caused to persons or other legal interests within the territory of another State." 112 Arguably, the same duty shall apply a fortiori to economic sanctions that are directly attributable to the State, especially. Unlawful assertion of jurisdiction through extraterritorial application of domestic (sanctions) measures, to the extent that it results in adverse effects (economic or otherwise) on third countries, shall also entail the international responsibility of the targeting State.

\section{Notes}

1 See, e.g., U.N. Doc. A/HRC/24/20, para. 11; A/HRC/28/7, para. 8.

2 See draft UNGA Resolution A/C.3/73/L.32, "Human rights and unilateral coercive measures," adopted on November 13, 2018, with 133 votes in favor, 53 against, and three abstentions.

3 For the most recent resolutions on that issue, see U.N. Doc. A/RES/72/168 (2017), $\mathrm{A} / \mathrm{RES} / 71 / 193$ (2016) and A/RES/70/151 (2015). 
4 See, inter alia, HRC Resolutions 27/21 (2014), 30/2 (2015), 36/10 (2017) and 37/21 (2018).

5 See, e.g., Non-Aligned Movement, Political Declaration of New York, September 20, 2017, where the Ministers of Foreign Affairs of the NAM "reaffirm their opposition to unilateralism and unilateral coercive measures imposed by certain States, including those of an economic, financial or trade nature not in accordance with international law, the Charter of the United Nations and the norms and principles governing peaceful relations among States, which can lead to the erosion and violation of the UN Charter, international law and human rights, the use and threat of use of force, and pressure and coercive measures as a means to achieving their national policy objectives, including those measures used as tools for political or economic and financial pressure against any country, in particular against developing countries," para. 6.

6 See, e.g., the Joint Communiqué of the 14th Meeting of the Foreign Ministers of the Russian Federation, the Republic of India and the People's Republic of China, April 18, 2016: "the imposition of unilateral sanctions, which exceed the ones agreed by the United Nations Security Council, is inconsistent with principles of international law, undermines the prerogatives of the United Nations Security Council as set forth in the UN Charter, reduces effectiveness of its sanctions regimes, disproportionally affects States against which they are imposed, as well as, when applied extra-territorially, has a negative impact upon third States and international trade and economic relations at large," para. 6.

7 See, e.g., Report of the Special Rapporteur on the negative impact of unilateral coercive measures on the enjoyment of human rights, Idriss Jazairy, U.N. Doc. A/HRC/30/45 (2015), para. 47.

8 See, e.g., Alexandra Hofer, "The Developed/Developing Divide on Unilateral Coercive Measures: Legitimate Enforcement or Illegitimate Intervention?" Chinese Journal of International Law, Vol. 16, No. 2 (2017), pp. 175-214.

9 U.N. Doc. A/RES/70/1, para. 30.

10 The present author wishes to disclose that he has been serving, since 2015, as legal consultant (legal adviser) to the UN Special Rapporteur.

11 U.N. Doc. A/RES/25/2625, Annex: Declaration on Principles of International Law concerning Friendly Relations and Co-operation among States in accordance with the Charter of the United Nations (1970).

12 See "Military and Paramilitary Activities in and Against Nicaragua (Nicaragua v. United States of America)," Judgment of June 27, 1986 (Merits), Separate Opinion of Judge Sette-Camara, I.C.J. Reports 1986, pp. 192, 199.

13 See, e.g., Daniel Thürer and Thomas Burri, "Self-Determination," in Rudiger Wolfrum ed., Max Planck Encyclopedia of Public International Law, Vol. IX (2012), para. 10.

14 ILC Yearbook 1950, Vol. I, p. 130, para. 5a.

15 1372nd meeting of the ILC (May 19, 1976) (in ILC Yearbook 1976, Vol. I, p. 62) (Mr. Tabibi).

16 1372nd meeting of the ILC (May 19, 1976) (in ILC Yearbook 1976, vol. I, p. 66) (Mr. Ago).

17 For a discussion of the controversy regarding the existence, and scope, of the prohibition of economic and political coercion, see, e.g., Antonio Tanca, "The Prohibition of Force in the UN Declaration on Friendly Relations of 1970," in Antonio Cassese ed., The Current Legal Regulation of the Use of Force (1986), pp. 397-412, esp. at pp. 400-402; Pierre-Emmanuel Dupont, "Countermeasures and Collective Security: The Case of the EU Sanctions Against Iran," Journal of Conflict and Security Law, Vol. 17 (2012), pp. 301-336.

18 See, e.g., A. Hofer, supra note 8; also U.N. Doc. A/73/175, Annex, para. 2.

19 See Application of the International Convention on the Elimination of All Forms of Racial Discrimination (Qatar v. United Arab Emirates). 


\section{Pierre-Emmanuel Dupont}

20 See U.N. Doc. A/73/175, para. 38 .

21 See U.N. Doc. A/73/175, paras. 16 sq.; A/71/287, para. 28; see also A/HRC/30/45. The Office of the United Nations High Commissioner for Human Rights has stated that humanitarian law provisions, such as the prohibition against the starvation of a civilian population as a method of warfare and the obligation to permit the free passage of all consignments of essential foodstuffs and medical supplies, are crucial for the evaluation of economic coercive measures (see A/HRC/19/33).

22 See N. Milaninia, "Jus ad bellum economicum and jus in bello economico: The Limits of Economic Sanctions Under the Paradigm of International Humanitarian Law," in Ali Z. Marossi and Marisa R. Bassett eds., Economic Sanctions Under International Law (2015), pp. 95-124, at p. 97.

23 Milaninia, supra note 22, p. 98. See also W.M. Reisman and D.L. Devick, "The Applicability of International Law Standards to United Nations Economic Sanctions Programmes," European Journal of International Law, Vol. 9 (1998), pp. 86-141, at p. 95.

24 U.N. Doc. A/HRC/30/45, para. 42.

25 CESCR, General Comment 8, The relationship between economic sanctions and respect for economic, social and cultural rights (Seventeenth session, 1997), U.N. Doc. E/C.12/1997/8 (1997), para. 16.

26 See, for example, the research-based progress report of the Human Rights Council Advisory Committee, U.N. Doc. A/HRC/28/74 (February 10, 2015), para. 15.

27 Erika De Wet, The Chapter VII Powers of the United Nations Security Council (2004), at p. 219.

28 S. Joseph and M. Castan, The International Covenant on Civil and Political Rights: Cases, Materials, and Commentary (2013), p. 203. See also Inter-American Court of Human Rights, Villagrán Morales and Others v. Guatemala Case (case of the "Street Children"), Judgment of November 19, 1999, Joint Concurring Opinion of Judges A.A. Cançado Trindade and A. Abreu Burelli, para. 2: "The right to life implies not only the negative obligation not to deprive anyone of life arbitrarily, but also the positive obligation to take all necessary measures to secure that that basic right is not violated."

29 For an affirmation of such duty in the context of multilateral sanctions enacted by the Security Council, see De Wet, supra note 27, at p. 221.

30 Convention on the Rights of the Child, November 20, 1989, 1577 UNTS 3, Articles 6 and 24(2).

31 De Wet, supra note 27, at p. 220.

32 Commission on Human Rights, "The Adverse Consequences of Economic Sanctions on the Enjoyment of Human Rights," Working Paper prepared by Mr. Marc Bossuyt, U.N. Doc. E/CN.4/Sub.2/2000/33 (June 21, 2000), para. 63.

33 See U.N. Doc. A/HRC/28/74, supra note 26.

34 "Alleged Violations of the 1955 Treaty of Amity, Economic Relations, and Consular Rights (Islamic Republic of Iran v. United States of America)," Provisional Measures, Order (October 3, 2018), para. 91.

35 Ben Saul, D. Kinley, and J. Mowbray, The International Covenant on Economic, Social and Cultural Rights: Commentary, Cases, and Materials (2014), p. 117.

36 Committee on Economic, Social and Cultural Rights, General Comment 8, supra note 25, para. 3.

37 Saul, Kinley, and Mowbray, supra note 35, p. 118.

38 Ibid., p. 107.

39 Resolution 2625 (XXV), Declaration on Principles of International Law concerning Friendly Relations and Co-operation among States in accordance with the Charter of the United Nations (A/RES/25/2625), October 24, 1970.

40 See Declaration on the right to development, U.N. Doc. A/RES/41/128 (December 4, 1986). 
41 U.N. Doc. A/HRC/RES/27/21, preamble. See also paras. 1, 4, 6, 10, and 15 of the same resolution.

42 I.D. Bunn, The Right to Development and International Economic Law (2012), p. 225.

43 For Cuba, see B. Manchak, "Comprehensive Economic Sanctions, the Right to Development, and Constitutionally Impermissible Violations of International Law," Boston College Third World Law Journal, Vol. 30 (2010), pp. 417-451, at pp. 433-434. For Myanmar, see Thihan Myo Nyun, "Feeling Good or Doing Good: Inefficacy of the U.S. Unilateral Sanctions Against the Military Government of Burma/Myanmar," Washington University Global Studies Law Review, Vol. 7 (2008), pp. 455-518.

44 Opening remarks by UN High Commissioner for Human Rights Navi Pillay, Harare, May 25, 2012, available at <www.ohchr.org/EN/NewsEvents/Pages/DisplayNews.aspx? NewsID=12192\&LangID=E\#sthash.48RBvc2r.dpuf $>$.

45 Thematic study of OHCHR on the impact of unilateral coercive measures on the enjoyment of human rights, including recommendations on actions aimed at ending such measures, U.N. Doc. A/HRC/19/33 (January 11, 2012), para. 35. See also in that respect A. Segall, "Economic Sanctions: Legal and Policy Constraints," International Review of the Red Cross, No. 836 (1999), who noted that "[i]t could be argued that the right to food and the right to be free from hunger impose an obligation on States to supply essential foodstuffs to those in need. Even if this argument is not accepted, at the very least the existence of these rights must mean that it is prohibited to deliberately act in a way which actively deprives individuals of food and causes hunger and/or starvation. As far as the imposition of sanctions is concerned, it would seem an extraordinary result if it were prohibited to starve civilians during an armed conflict but permitted in time of peace."

46 CESCR, General Comment No. 12: The right to adequate food, U.N. Doc. E/C. 12/1999/5 (May 5, 1999), para. 37. For a legal argument for a ban on the use of food and medicine as part of economic sanctions strategies, see J.J. Paust, "De-Regulating Humanitarian Aid: The Need for New Norms and Interpretation," in I. Buffard, James Crawford, and Alain Pellet, and Simon Olleson eds., International Law Between Universalism and Fragmentation: Festschrift in Honour of Gerhard Hafner (2008), pp. 701-709.

47 Situation of human rights in Cuba, U.N. Doc. A/HRC/4/12 (January 27, 2007), para. 7.

48 Resolution A/HRC/15/L.14, Human rights and access to safe drinking water and sanitation (2010).

49 CESCR, General Comment 15, The right to water (Twenty-ninth session, 2003), U.N. Doc. E/C.12/2002/11 (2002); See S.M.A. Salman and S. McInerney-Lankford, The Human Right to Water, Legal and Policy Dimensions (2004), pp. 76-77.

50 Concluding observations of the Human Rights Committee, CCPR/C/ISR/CO/3, September 3, 2010, para. 8 .

51 See, e.g., General Assembly Resolution 66/156 (2011); General Assembly Resolution 68/162 (2013).

52 See, e.g., Human Rights Council Resolution 15/24 (2011); Human Rights Council Resolution 27/21 (2014).

53 See, e.g., U.N. Doc. A/HRC/28/74, supra note 26, paras. 14-19.

54 Sub-commission on Human Rights, Resolution 2000/1, Human rights and humanitarian consequences of sanctions, including embargoes, U.N. Doc. E/CN.4/SUB.2/ RES/2000/1 (August 11, 2000).

55 For a comprehensive overview and evaluation of the effects of the sanctions on the Iraqi people, see, e.g., U.N. Doc. S/1999/356 (March 30, 1999), Annex II: Report of the Panel on the humanitarian situation in Iraq; U.N. Doc. E/CN.4/Sub.2/2000/33, supra note 32; World Health Organization (Division of Emergency and Humanitarian Action), "The Health Conditions of the Population of Iraq Since the Gulf Crisis," (1996), 
WHO/EHA/96.1, available at <http://apps.who.int/iris/bitstream/10665/59845/1/ WHO_EHA_96.1.pdf?ua=1> (accessed August 2, 2015).

56 For unilateral coercive measures currently in force, see, e.g., regarding Cuba, U.N. Doc. A/HRC/28/74, supra note 26, paras. 24-27; for Iran, see ibid., paras. 34-35. Regarding Iran, reference shall be made to reports according to which 85,000 cancer patients in Iran, who require chemotherapy and radiotherapy treatment, "are under imminent risk, an unwarranted side-effect of sanctions," largely because the country is not allowed to use the international payment systems, having been disconnected from the SWIFT system as a result of sanctions (P. Pinto Soares, "UN Sanctions That Safeguards, Undermine, or Both, Human Rights," in J.P. Bohoslavsky and J.L. Cernic eds., Making Sovereign Financing and Human Rights Work (2014), pp. 33-46, see esp. at pp. 38-40). For an example of unilateral coercive measures no longer enforced (Burundi), see U.N. Doc. E/CN.4/Sub.2/2000/33, paras. 79, 82.

57 CESCR, General Comment 14, The right to the highest attainable standard of health (Twenty-second session, 2000), U.N. Doc. E/C.12/2000/4 (2000), para. 41.

58 See J. Tobin, The Right to Health in International Law (2012), p. 332.

59 The right of everyone to the enjoyment of the highest attainable standard of physical and mental health, U.N. Doc. A/59/422 (October 8, 2004), para. 33.

60 See Tobin, supra note 58, pp. 332-333.

61 To borrow the words used by De Wet, supra note 27, where she underlined the obligations imposed on States under the right to health as to the design and implementation of embargoes enacted by the UN Security Council.

62 "Alleged Violations of the 1955 Treaty of Amity, Economic Relations, and Consular Rights (Islamic Republic of Iran v. United States of America)," Provisional Measures, Order (October 3, 2018), para. 91.

63 CESCR, General Comment 8 (footnote 5), para. 3. See K.D. Beiter, The Protection of the Right to Education by International Law (2006), esp. at p. 367.

64 U.N. Doc. S/1999/356, supra note 55, paras. 19-20.

65 Preliminary research-based report on human rights and unilateral coercive measures, U.N. Doc. A/HRC/AC/13/CRP.2 (July 30, 2014), para. 29.

66 Letter from the Permanent Representatives of China, France, the Russian Federation, the United Kingdom of Great Britain and Northern Ireland, and the United States of America to the United Nations Addressed to the President of the Security Council, U.N. Doc. S/1995/300 (April 13, 1995).

67 See Mary Ellen and O'Connell, "Debating the Law of Sanctions," European Journal of International Law, Vol. 13 (2002), pp. 63-79, at p. 74.

68 U.N. Doc. A/54/1.

69 See Sue E. Eckert, "The Evolution and Effectiveness of UN Targeted Sanctions," in L. van den Herik ed., Research Handbook on UN Sanctions and International Law (2017), pp. 52-70.

70 Statement by Sweden at the UN Security Council Briefing on Sanctions, August 3, 2017.

71 See UN Secretary-General, "Comparative Summary of Existing Communications and Inquiry Procedures and Practices Under International Human Rights Instruments and Under the United Nations System," U.N. Doc. E/CN.4/2005/WG.23/2 (November 22, 2004).

72 See U.N. Doc. A/70/345, paras. 38-44.

73 Optional Protocol to the ICESCR, Article 9(3).

74 See, e.g., J. Kuijper et al., The Law of EU External Relations, Cases, Materials, and Commentary on the EU as an International Legal Actor (2015), 215.

75 See Council of the EU, "Guidelines on Implementation and Evaluation of Restrictive Measures (Sanctions) in the Framework of the European Union Common Foreign and Security Policy," (updated 2018), available at $<$ http://data.consilium.europa.eu/doc/ document/ST-5664-2018-INIT/en/pdf>, para. 9. 
76 Ibid., para. 25.

77 See U.N. Doc. A/HRC/39/54/Add.1, para. 25.

78 See Yassin Abdullah Kadi and Al Barakaat International Foundation v. Council of the European Union and Commission of the European Communities, Judgment of the Court (Grand Chamber) of September 3, 2008, Joined cases C-402/05 P and C-415/05 P, European Court Reports 2008 I-06351. In this case the Court made clear that " $[\mathrm{t}] \mathrm{he}$ Community judicature must . . in accordance with the powers conferred on it by the EC Treaty, ensure the review, in principle the full review, of the lawfulness of all Community acts in the light of the fundamental rights forming an integral part of the general principles of Community law, including review of Community measures which, like the regulation at issue, are designed to give effect to the resolutions adopted by the Security Council under Chapter VII of the Charter of the United Nations."

79 Judge Allan Rosas, Presentation at a Seminar on EU restrictive measures, Ministry of Foreign Affairs, Tallinn, February 5, 2016, "EU Sanctions Policies: Value Imperialism, Futile Gesture Politics or Extravaganza of Judicial Control?": "Whilst in 2006 five actions for the annulment of such acts were brought before the General Court, the more recent figures are as follows: 93 new such cases in 2011, 59 in 2012, 41 in 2013, 69 in 2014 and finally 55 in 2015 . Much less cases are brought on appeal to the ECJ. In 2015, for instance, the Court decided seven such cases."

80 Article 263, para. 4, TFEU, provides that "[a]ny natural or legal person may . . . institute proceedings against an act [of an EU institution] addressed to that person or which is of direct and individual concern to them, and against a regulatory act which is of direct concern to them and does not entail implementing measures."

81 This was found to have occurred, e.g., in Safa Nicu Sepahan v. Council, General Court of the EU, Case T-384/11, Judgment of November 25, 2014.

82 See D. Chalmers, G. Davies, \& G. Monti, European Union Law (2010), pp. 396 ff. Also M. Cremona, "EC Competences, 'Smart Sanctions,' and the Kadi Case," Yearbook of European Law, Vol. 28 (2009), pp. 559-592.

83 Judge Allan Rosas, Presentation, supra note 79.

84 During his interviews with ECJ President Leanaerts and Judges von Danwitz and Rosas in Luxembourg on May 25, 2016, the Special Rapporteur was unable to obtain an explicit answer on that point.

85 See Council of the EU, "Guidelines on Implementation and Evaluation of Restrictive Measures (Sanctions) in the Framework of the EU Common Foreign and Security Policy," (updated 2012), Doc. 11205/12, para. 9.

86 See J. Rideau, "Recours en annulation - Conditions de recevabilité," Juris Classeur Europe Traité (Lexis Nexis, 2011), para. 71. At least one case (unrelated to sanctions) has actually been brought by a non-EU Member State, the Swiss confederation, against the European Commission before the ECJ; see Case C-547/10P, Judgment of March 7, 2013.

87 See A. Rosas, "Counter-Terrorism and the Rule of Law: Issues of Judicial Control," in A.M. Salinas de Frias, K.L.H. Samuel, and N.D. White eds., Counter-Terrorism, International Law and Practice (2012), pp. 83-110, at p. 91.

88 See Safa Nicu Sepahan v. Council, General Court of the EU, Case T-384/11, Judgment of November 25, 2014.

89 See U.N. Doc. A/HRC/36/44, para. 33, quoting M. Craven, "The Violence of Dispossession: Extra-Territoriality and Economic, Social, and Cultural Rights," in M. Baderin and R. McCorquodale eds., Economic, Social, and Cultural Rights in Action (2007), p. 71.

90 O. De Schutter, “A Human Rights Approach to Trade and Investment Policies," (November 2008), at para. 3.2, available at <www.iatp.org/sites/default/files/451_2_104504. pdf $>$.

91 Ibid. 
92 Human Rights Committee, Sergio Euben Lopez Burgos v. Uruguay, Communication No. R.12/52, U.N. Doc. Supplement No. 40 (A/36/40) (1981), para. 12.3. See T. Soboka Bulto, The Extraterritorial Application of the Human Right to Water in Africa (2014), esp. pp. 168-169.

93 M. Sepulveda and C. Courtis, "Are Extra-Territorial Obligations Reviewable Under the Optional Protocol to the ICESCR?" Nordic Journal of Human Rights, Vol. 27 (2009), pp. 54-63, at p. 55. See also Marko Milanovic, Extraterritorial Application of Human Rights Treaties (2011), p. 17; U.N. Doc. A/HRC/36/44, para. 34.

94 ICESCR, Article 2(1): "Each State Party to the present Covenant undertakes to take steps, individually and through international assistance and co-operation, especially economic and technical, to the maximum of its available resources, with a view to achieving progressively the full realization of the rights recognized in the present Covenant by all appropriate means, including particularly the adoption of legislative measures."

95 See U.N. Doc. A/HRC/36/44, para. 34.

96 Craven, supra note 89, p. 71.

97 See, e.g., F. Coomans, "The Extraterritorial Scope of the International Covenant on Economic, Social and Cultural Rights in the Work of the United Nations Committee on Economic, Social and Cultural Rights," Human Rights Law Review, Vol. 11, No. 1 (2011), pp. 1-35.

98 See Gondek, The Reach of Human Rights in a Globalising World: Extraterritorial Application of Human Rights Treaties (2009); Coomans, supra note 97, p. 6.

99 See "Legal Consequences of the Construction of a Wall in the Occupied Palestinian Territory, Advisory Opinion," ICJ Reports (2004), p. 136, para. 112, referring to the findings of the CESCR that "the State party's obligations under the Covenant apply to all territories and populations under its effective control" (E/C.12/1/Add. 90, paras. 15 and 31). See also EctHR, March 23, 1995, Loizidou v. Turkey (preliminary objections), No. $15318 / 89$, para. 62: "[T] he responsibility of a Contracting Party may also arise when as a consequence of military action - whether lawful or unlawful - it exercises effective control of an area outside its national territory."

100 See U.N. Doc. A/HRC/36/44, para. 35.

101 As noted in the draft General Comment on State Obligations under the International Covenant on Economic, Social and Cultural Rights in the Context of Business Activities (October 17, 2016), E/C.12/60/R.1, para. 32.

102 See N. Vennemann, "Application of International Human Rights Conventions to Transboundary State Acts," in R.M. Bratspies and R.A. Miller eds., Transboundary Harm in International Law, Lessons from the Trail Smelter Arbitration (2006), pp. 295-307; de Schutter et al., "Commentary to the Maastricht Principles on Extraterritorial Obligations of States in the Area of Economic, Social and Cultural Rights," Human Rights Quarterly, Vol. 34 (2012), p. 1084; L. Bartels, “The EU's Human Rights Obligations in Relation to Policies With Extraterritorial Effects," European Journal of International Law, pp. 1071-1091, at pp. 1081-1083; also A/HRC/36/44, para. 36.

103 General Comment No 8: The relationship between economic sanctions and respect for economic and social rights, December 4, 1997, U.N. Doc. E/C.12/1997/8, para. 11.

104 Ibid., para. 14.

105 Ibid., para. 13.

106 General Comment No 14: The right to highest attainable standard of health (Article 12), July 4, 2000, U.N. Doc. E/C.12/2000/4, para. 41.

107 U.N. Doc. A/HRC/36/44, para. 39. See Coomans, supra note 97, p. 8. 
108 See "The Optional Protocol to the International Covenant on Economic, Social and Cultural Rights," In-Brief No. 2 of the Geneva Academy of International Humanitarian Law and Human Rights (July 2013), p. 12.

109 See ibid., pp. 12-13.

110 See U.N. Doc. A/HRC/33/48, para. 68.

111 Article 1, Draft Articles on Responsibility of States for Internationally Wrongful Acts, text adopted by the International Law Commission at its 53rd session in 2001 (A/56/10), annexed to UN General Assembly Resolution 56/83 of December 12, 2001.

112 Ian Brownlie, System of the Law of Nations: State Responsibility (1983), p. 165. Applying that principle in another area is the CESCR's General comment No. 24 (2017) on State obligations under the International Covenant on Economic, Social and Cultural Rights in the context of business activities. U.N. Doc. E/C.12/GC/24, esp. paras. 25 sq. 


\title{
$4 \quad$ Legality of extraterritorial sanctions
}

\author{
Mirko Sossai
}

\section{Introduction}

The US withdrawal from the Joint Comprehensive Plan of Action (JCPOA) - the landmark nuclear agreement signed in July 2015 - has marked the end of the coordinated lifting of nuclear related sanctions endorsed by the UN Security Council with Resolution 2231 (2015). ${ }^{1}$ By expressing its deep regret for the US announcement, the European Union (EU) declared to remain committed to the continued full and effective implementation of the nuclear deal, as long as Iran continued to implement its nuclear related commitments. ${ }^{2}$

In announcing the US withdrawal from the JCPOA, President Donald Trump issued a Presidential Memorandum reimposing "all United States sanctions lifted or waived in connection with the JCPOA" ${ }^{\prime 3}$ within 180 days. These sanctions which included both "primary" and "secondary" sanctions - were to be implemented in two phases: phase one entered into effect 90 days later on August 7, 2018 , for various non-energy-related sanctions, while phase two began 180 days later on, November 5, 2018, for the remaining sanctions. ${ }^{4}$ The EU responded to the reimposition of the so-called secondary sanctions by the US with the update of the Blocking Regulation, as a countermeasure vis-à-vis the illegal extraterritorial effect of such measures. ${ }^{5}$

The application of secondary sanctions, targeting activities of non-US persons with no connection to the US, has proven highly controversial. Insofar as they constitute exercise of jurisdiction on an extraterritorial basis, they raise concerns from the viewpoint of international law, as they may violate, inter alia, the principle of nonintervention in the internal affairs of other States. ${ }^{6}$ The European refusal to recognize the effects of this type of sanction is not a new phenomenon: the Blocking Regulation was originally approved in $1996^{7}$ to counteract the effects of certain extraterritorial sanctions adopted by the US vis-à-vis Cuba, Libya, and Iran. At that time, similar initiatives were undertaken by Canada and Mexico. ${ }^{8}$

The purpose of this chapter is to offer an overview of the different generations of the US "extraterritorial sanctions," with a focus on the different positions concerning their legality from an international law viewpoint. It is also important to assess the effectiveness of the initiatives taken by the EU, by way of countermeasure, in order to neutralize the effects of US extraterritorial jurisdiction. The new 
scenario opened by the US announcement on the withdrawal from the Iran nuclear deal has brought additional legal complexity: SWIFT, the Belgian company providing an international system for facilitating cross-border payments, has become the symbol of how companies risked being caught in a transatlantic dilemma in relation to the decisions made once the US financial sanctions have entered into force.

\section{Different "generations" of US extraterritorial sanctions}

The organizing principles of the coercive measures taken by the US against Iran are the distinction between primary and secondary sanctions, based on the identity of the targets, on the one hand, and the distinction based on the purpose between nuclear and nonnuclear ones, on the other. ${ }^{9}$

In other words, secondary sanctions are supplementary to primary sanctions, which restrict economic relations directly between an imposing State - and its own individuals and companies - and a target of the sanctions: it presupposes that third-party countries have not instituted comparable sanctions to prohibit their own citizens and companies from doing business with the target State. ${ }^{10}$

The specific legal nature of US autonomous sanctions needs to be understood against the background of the complex framework of unilateral and multilateral actions against Iran's nuclear program. This has been a paradigmatic example of the cumulative effect of different layers of sanctions, where unilateral measures by the US, the EU, and other countries - supplemented and expanded UN sanctions. ${ }^{11}$ As for the content, they show the shift in focus regarding the use of financial sanctions in order to isolate the target State from the credit and monetary markets. ${ }^{12}$

If autonomous sanctions - either adopted by individual states or by regional organizations - coexist with UN sanctions, then a key question arises as to whether the former should be qualified as enforcement measures on the basis of UN sanctions or, rather, as additional measures, whose legality needs to be appreciated under general international law. In this second scenario, autonomous sanctions may be regarded as acts of retorsion if they constitute "unfriendly" conduct not inconsistent with any international obligation; if unlawful, they can be justified as countermeasures.

Apt characterization is essential to determine the legal status and effects of unilateral coercive measures as well as their potential continuation after termination of UN sanctions. Moreover, the requirement of proportionality operates on the basis of different standards: while countermeasures must be commensurate with the injury suffered and the gravity of the wrongful act, the evaluation of UN sanctions should be conducted on the basis of the objectives to be achieved, taking into account the possible adverse humanitarian consequences. ${ }^{13}$ An assessment on the legality of the economic sanctions vis-à-vis Iran would require to determine if the US were entitled to take countermeasures as a reaction to an alleged breach of international law, i.e., the interdependent obligations under the Treaty on the Non-Proliferation of Nuclear Weapons, ${ }^{14}$ and whether recourse to 
countermeasures remains open to States once the UN Security Council has taken action under Chapter VII. ${ }^{15}$

It remains that, since the beginning of the 1980s, a specific feature of US sanctions is that they have been aimed at increasing the economic isolation of the targeted States by intervening in the commercial and financial relations among actors that are not active within its jurisdiction. Such measures have been qualified as extraterritorial in the sense that they seek to affect the conduct of foreign persons outside the US. The goal of "universalizing" its primary sanctions has resulted in an attempt to reduce the discretion that third States could exercise in their foreign policy vis-à-vis the targeted State. ${ }^{16}$

\section{The first generation}

The extraterritoriality of the US secondary sanctions has progressively expanded during the last three decades, to the extent that it is possible to identify at least two generations. Although broad, the "first generation" of extraterritorial measures introduced in the 1980s and 1990s were relatively precise in their stated scope and in their enforcement. ${ }^{17}$ The paradigmatic example was represented by the enactment of "secondary boycotts" and export controls: provided that the unilateral decision not to export goods to another country is of limited usefulness if other States do not join it, the US has attempted to prohibit companies incorporated in third States from exporting to the State that had already been subject to a "primary" boycott. ${ }^{18}$

The 1982 Soviet Pipeline Regulations - an embargo on the supply of pipeline equipment aimed at inducing the USSR to adopt a less intrusive attitude toward Poland - received broad criticism because it included in its scope of application foreign subsidiaries of US companies. ${ }^{19}$ Even more numerous negative reactions were directed against the extraterritorial nature of both the Helms-Burton $\mathrm{Act}^{20}$ and the Iran and Libya Sanctions Act (ILSA) of 1996. ${ }^{21}$ Title III of the Helms-Burton Act authorizes civil suits by US nationals against any individual or entity - regardless of their nationality - that "traffics" in property that has been confiscated by the Cuban government following the 1959 socialist revolution. A separate title of the statute requires the US Secretary of State to deny visas to any corporate officer or controlling shareholder of a company that has trafficked in a US national's property confiscated by the Cuban government. ${ }^{22}$ As for ILSA, the act imposed sanctions on any foreign person or entity investing more than \$20 million in either Iran or Libya to support the development of its petroleum resources.

In an attempt to resist the extraterritorial reach of secondary sanctions, the EU even initiated WTO dispute settlement proceedings, complaining that the extraterritorial effects of the act were inconsistent with the international obligations of the US under GATT 1994 and GATS. In April 1997, the US and the EU decided to settle the dispute by concluding a series of "understandings" aimed at suspending the effects of Helms-Burton on European companies. ${ }^{23}$ Since then, Title III of the Helms-Burton Act has been fully waived by every US president not only 
because of the opposition from the international community but also because of fears that it could create chaos in the US court system with a flood of lawsuits. However, in 2019 the US Secretary of State Mike Pompeo, in an unprecedented move, announced the decision to not renew the waiver: ${ }^{24}$ both Canada and the EU reacted considering "the extraterritorial application of unilateral Cuba-related measures contrary to international law." 25

The issue of the legality of extraterritorial measures was brought to universal attention within the context of the UN General Assembly. Since 1992, a resolution on the "necessity of ending the economic, commercial and financial embargo imposed by the United States of America against Cuba" has received increasing support year by year: significantly, concern has been expressed vis-à-vis "the promulgation and application ... of laws and regulations whose extraterritorial effects affect the sovereignty of other States and the legitimate interests of entities or persons under their jurisdiction, as well as the freedom of trade and navigation." ${ }^{26}$ However, it is important to bear in mind that the UN General Assembly actually appears much more divided when voting on resolutions condemning "unilateral coercive measures," which are introduced on a regular basis by the Non-Aligned Movement and the Group of $77 .{ }^{27}$

\section{The second generation}

The second generation of extraterritorial sanctions has been characterized by the focus on the financial sector. ${ }^{28}$ The paradigmatic example of such a development is represented by the US sanctions against Iran: not only did the Comprehensive Iran Sanctions, Accountability, and Divestment Act of 2010 (CISADA) include restrictions on the supply of refined petroleum and refining equipment or services by foreign or domestic persons and entities, but it also imposed serious limits on foreign financial institutions' access to the US financial system if they engaged in certain transactions involving Iran. ${ }^{29}$

The enactment by the US Congress of the Countering America's Adversaries Through Sanctions Act (CAATSA) in July 2017 - which contained sanctions targeting Russia, North Korea, and Iran - marked a further evolution: as for Russia, not only did the new piece of legislation codify existing sanctions against Russia, but it also imposed new coercive measures and restricted the US President's authority to modify or eliminate these sanctions without congressional approval. ${ }^{30}$ As concerns their extraterritorial reach, non-US persons face potential secondary sanctions risk if they enter into or facilitate "significant" transactions for or on behalf of targeted persons and entities.

What characterizes the second wave of US economic sanctions is that they include not only limits on trade, i.e., restrictions on particular exports or imports, but, most importantly, the blocking of assets and interest in assets subject to US jurisdiction; limits on access to the US financial system, including limiting or prohibiting transactions involving US individuals and businesses; and restrictions on private and government loans, investments, insurance, and underwriting. ${ }^{31}$ Although the sanctions programs are administered by several US government 
agencies, the primary administrator is the Treasury Department's Office of Foreign Assets Control (OFAC), which publishes the list of so-called Specially Designated Nationals (the SDN List) and enforces these measures. OFAC and the US Department of Justice have targeted non-US financial institutions in a series of high-profile sanctions enforcement actions over the last decade. The comprehensive settlement with the PNB Paribas - accused of violating US sanctions against Iran, Sudan, Burma, and Cuba from 2005 to 2012 - demonstrated how OFAC effectively and aggressively applied US sanctions law to foreign institutions incorporated and doing business abroad; the French bank acknowledged the violations and also agreed to pay a total of $\$ 8.97$ billion (USD). ${ }^{32}$

The point has been made that this new generation of sanctions is characterized by a "chilling effect," as banks and corporations declined to engage in legally permissible transactions because legislation is unclear, and the consequences in case of violation would be catastrophic. ${ }^{33}$ In the three-year period between the lifting of secondary sanctions against Iran in 2016 and their reimposition in 2018, reports stressed the difficulties in navigating the complex web of residual sanctions within Iran's opaque economy: "Due diligence is costly and cumbersome, and its standard is ill-defined, adversely affecting businesses' risk-reward calculus of trying to comply while operating within the Iranian economy's opaque ownership structure." ${ }^{34}$ European financial institutions were hesitant to play a role in any transactions with Iran, as the basis for the previous heavy fines were, put in general terms, actions or omissions by which they assisted their customers to make payments that involved the US financial system.

The Financial Action Task Force (FATF) has used the term "de-risking" to describe this phenomenon: it refers to the practice of financial institutions terminating or restricting business relationships with clients or categories of clients to avoid, rather than manage, risk. ${ }^{35}$ In the period of relaxation in the US sanctions policy vis-à-vis Iran, the ambiguities concerning dollar-clearing transactions played a significant role in explaining the difficulties in taking advantage of the business opportunities in Iran. Significantly, OFAC had to publish additional guidance on the US dollar transactions and appropriate due diligence by non-US persons engaging in business involving Iran: it clarified that foreign financial institutions, including foreign-incorporated subsidiaries of US financial institutions, could process transactions denominated in US dollars or maintain US dollar-denominated accounts involving Iran, so long as the transactions do not involve, directly or indirectly, the US financial guarantee fund, in order to facilitate international finance for small- and medium-sized investments. ${ }^{36}$

\section{Do EU restrictive measures have extraterritorial effects too?}

Given that the EU "has condemned the extra-territorial application of third country's legislation imposing restrictive measures which purports to regulate the activities of natural and legal persons under the jurisdiction of the Member States of the European Union," it comes with no surprise that the EU Sanctions 
Guidelines stress that the EU "will refrain from adopting legislative instruments having extra-territorial application in breach of international law." 37

The same document makes clear that the application of EU restrictive measures is limited to situations where links exist with the EU. The standard clause setting out to what extent an EU regulation concerning restrictive measures should apply covers the territory of the EU, including its airspace; aircrafts or vessels of Member States; nationals of Member States, inside or outside the territory of the EU; companies and other entities incorporated or constituted under Member States' law; or any business done in whole or in part within the EU. ${ }^{38}$

It follows that usually non-EU subsidiaries of an EU parent company are not subject to the European restrictive measures if they are incorporated outside the EU, and if they do not do business in the EU. Therefore, EU guidelines warn entities incorporated in an EU Member State against using "a company that it controls as a tool to circumvent a prohibition, including where that company is not incorporated in the EU" or giving instructions to such effect. ${ }^{39}$

It has been observed that the EU has sought to expand the jurisdictional scope of its restrictive measures in an indirect manner by inviting certain third countries to align with its imposed sanctions. ${ }^{40}$ Since the mid-1990s, the EU has been successful in involving a considerable number of neighboring countries, particularly candidate States, potential candidates, and members of the European Economic Area (EEA). ${ }^{41}$ However, third States might be reluctant in joining the EU restrictive measures: with the notable absence of Serbia and Turkey, only Montenegro, Albania, Norway, and Ukraine aligned themselves with the most recent sanctions against Russia. It might happen that nonalignment is due to time pressure, or that an aligning government decided to settle on a policy of not taking part in EU declarations about the sanctions. ${ }^{42}$ In principle, under international law third States remain free to decide whether to join EU sanctions or not; however, in the light of the principle of good faith, candidate countries having started accession negotiations are under certain not to intentionally undermine the Common Foreign and Security Policy (CFSP). ${ }^{43}$

\section{A transatlantic divide on the legality of secondary sanctions}

Secondary sanctions are to be generally defined as those that expose foreign natural and legal persons in third countries to sanctions when they conduct business with individuals, groups, regimes, or countries that are the target of the "primary" sanctions regime. ${ }^{44}$ They fall within the category of extraterritorial measures in that they correspond to situations where a State enacts and enforces laws and regulations aimed at controlling the conduct of entities that are situated outside its territory, overriding the power of the territorial sovereign to regulate the same course of conduct. ${ }^{45}$

The basic question remains the one identified by Andrea Bianchi more than two decades ago: to what extent, in the absence of an international agreement, can the regulating State lawfully impose, under international law, obligations on foreign 
subjects - be they natural persons or corporate entities - or pretend to regulate transactions carried out well outside its territory? ${ }^{46}$

It has been correctly observed that the issue of extraterritoriality further exacerbates the question of the legality of unilateral nonforcible measures in case of violations of erga omnes obligations, i.e., obligations due to the international community as a whole. ${ }^{47}$ It is important to situate the question of the jurisdictional scope of such measures against the background of the tension between an understanding of sanctions as coercive measures imposed by centralized authorities, like the UN, and the autonomous attempts by third states to enforce selfdefined community norms outside of the institutional collective security regime. Assuming that only the UN and competent regional organizations have the power to impose collective measures that bind all Member States to adopt nonforcible measures, "no single state has the power to bind other states to act in this way, although they may try to enmesh other states and actors by including an extraterritorial element in unilateral non-forcible measures imposed on a target state." 48

The starting point of any discussion on the issue of the jurisdictional scope of economic sanctions remains the basic principle of territoriality: ${ }^{49}$ there is no doubt that the principle of nonintervention in the internal affairs of other States restricts the extraterritorial exercise of state powers, insofar as it prohibits acts of coercion by one state on the territory of another state without the latter's consent. ${ }^{50}$ National laws may be given extraterritorial application, provided that these laws could be justified by one of recognized principles under customary international law. ${ }^{51}$ Of course, the application of such principles to concrete situations is open to interpretation.

The US has relied on the principle of active personality to claim jurisdiction over foreign companies that are owned or controlled by a US person: however, the application of the so-called control theory has been largely rejected as contrary to international law on the basis of the Barcelona Traction case holding. ${ }^{52}$ Alternatively, the authors of the 1996 Helms-Burton Act invoked the controversial effects doctrine, by including a statement in the act that reads as follows: "International law recognizes that a nation has the ability to provide for rules of law with respect to conduct outside its territory that has or is intended to have substantial effect within its territory." However, those efforts were strongly criticized in the literature. ${ }^{53}$ Alternatively, one might wonder whether the Helm-Burton Act could be better justified under the protective principle - which protects the State from acts perpetrated abroad that jeopardize its sovereignty or its right to political independence - as it considered Cuba to be posing a national security threat to the US; however, the point has been made that "there is/was apparently no convincing evidence of terrorist activity sponsored by the Cuban government nor of the specific security threat posed by mass migration of Cubans to the United States." ${ }^{4}$

Finally, many have argued that secondary sanctions cannot be justified under Article XXI (b) of the GATT ${ }^{55}$ - which excuses a Member State of the WTO from measures "it considers necessary for the protection of its essential security interests" - even where primary sanctions might satisfy it: the reference to the "essential" character of the security interests seems to preclude measures against 
trading partners which have a very "indirect, remote, and attenuated" relationship to the them. ${ }^{56}$

The controversies on the legal basis of secondary sanctions should not lead to the conclusion of their unlawful nature in any circumstances. An author has suggested that a wide range of such measures might be permissible "if tailored to regulate exclusively on 'terrinational' grounds, on the combined basis of territorial and nationality jurisdiction." ${ }^{57}$ Still, the amount of protest vis-à-vis the content of certain measures aimed at exercising authority over foreign persons and entities should be seen as obstacles to the crystallization of a norm of customary international law, which would expand extraterritorial jurisdiction for foreign policy objectives. ${ }^{58}$

This seems to find further confirmation in the entry into force of the amendments to the Blocking Regulation on August 7, 2018, which has demonstrated the European choice of a confrontation with the US based on the legal terrain; in the explanatory memorandum on the draft text, the European Commission observed that

Some of the measures which the United States will reactivate against Iran have extraterritorial effects and, in so far as they unduly affect the interests of natural and legal persons established in the Union and engaging in trade and/or the movement of capital and related commercial activities between the Union and Iran, they violate international law and impede the attainment of the Union's objectives. ${ }^{59}$

The EU had introduced the Blocking Statute in 1996 as a countermeasure, within the meaning of Article 49 of the Draft Articles on State Responsibility, in response to the US extraterritorial sanctions legislation concerning Cuba, Iran, and Libya. In August 2018, the Guidance Note to the updated regulation affirms that

the Blocking Statute aims to protect the established legal order, the interests of the Union and the interests of natural and legal persons exercising rights under the Treaty on the Functioning of the European Union against the unlawful effects of extra-territorial application of such legislation. ${ }^{60}$

It follows that the EU counteraction points to the unlawful character of the secondary sanctions because of their contrariety with the principle of nonintervention. One could have the impression of a continuity in the position of the European countries throughout the last two decades. However, in the period 2010-2012, EU Member States seemed to manifest acquiescence vis-à-vis the extraterritorial dimension of the US comprehensive Iran sanctions adopted at that time. Following the adoption of UNSC Resolution 1929 (2010), ${ }^{61}$ less than a month after President Barack Obama signed CISADA, the EU widened the scope of its restrictive measures against Iran in order not only to implement the UN sanctions but also to introduce "accompanying measures," focusing "on the areas of trade, 
the financial sector, the Iranian transport sector, key sectors in the oil and gas industry." ${ }^{12}$ Moreover, following intense negotiations with the US, ${ }^{63}$ the EU Council agreed on additional restrictive measures in 2012, which definitely mirrored those imposed by the US. ${ }^{64}$ Interestingly, Regulation 267/2012 prohibited specialized financial messaging providers, such as SWIFT, from providing services to EU-sanctioned Iranian banks. ${ }^{65}$

It has been observed that the EU avoided the question of whether US sanctions apply to nationals of EU Member States by imposing almost the same restrictions itself. $^{66}$ Others noted ${ }^{67}$ that when BNP Paribas was under investigation in 2014, French President François Hollande wrote to President Obama to complain that the expected fine would be disproportionate, but he did not challenge the legitimacy of the measure ${ }^{68}$ However, it is a shared view that the EU practice should not be read as accepting extraterritorial sanctions as legitimate in all circumstances. The EU considered the additional restrictive measures adopted in 2010-2012 as tools aimed at strengthening the existing UN sanctions, given the dissatisfaction as to their impact and effects. At that time, the EU Council stressed that "Iran continues to refuse to comply with its international obligations and to fully cooperate with IAEA to address concerns on its nuclear programme, and instead continues to violate those obligations." ${ }^{99}$ It goes without saying that China and Russia expressed strong opposition against the practice of unilateral sanctions, as they contravened the principle of sovereign equality of UN Member States, undermined the authority of the UNSC, and was counterproductive to crisis resolution. ${ }^{70}$

\section{On the legality of the reimposition of sanctions on the basis of the JCPOA}

One of the most relevant aspects of the JCPOA has been the introduction of a "snap back" procedure which ensures sanctions reimposition in case of significant nonperformance of the commitments under the deal: this mechanism provides that, on the basis the notification of "a JCPOA participant State," the UNSC deliberates on a resolution to continue the termination of its sanctions. The consequence of a failure in adopting the decision - for instance because of the negative vote of a permanent member - is the reintroduction of the sanctions regime. ${ }^{71}$ The risk of "snap back" represented a relevant variable which influenced decisions on business opportunities in Iran: companies were advised to introduce specific contractual protections in order to manage risks of snap back. ${ }^{72}$

However, the US administration did not rely on a "snap back" procedure. The concept of proportionality was, on the contrary, invoked in the context of the reimposition of what the US regarded only as suspended sanctions against Iran. President Trump's decision to decertify the nuclear deal in October 2017, was made on the assumption that the suspension of sanctions was not "appropriate and proportionate" 73 to the steps that Iran has taken to end its illicit nuclear activities. The position of the Trump Administration is that the JCPOA is a deal, definitely based on reciprocal commitments, but political and therefore nonbinding. This was, of course, due to domestic reasons: the Obama Administration would have had difficulties in getting the consent from the US Congress. ${ }^{74}$ 
The reaction of the EU seems to convey a different message on the nature of the JCPOA. After the US withdrawal from it, the EU High Representative Federica Mogherini declared that: "the nuclear deal is not a bilateral agreement and it is not in the hands of any single country to terminate it unilaterally." "75 It has been observed that the declaration of the High Representative would announce a confrontation with the US to be held within the framework of international law. In the first place, the EU position seemed to imply that not only does the JCPOA possess the nature of a treaty governed by international law, but the deal is also a multilateral agreement designed to pursue collective objectives. Second, the EU has a legal interest in the implementation of the JCPOA and is entitled to claim compliance with it. It follows that only a breach of its commitments by Iran may justify a corresponding breach by the other parties. ${ }^{76}$

Such an alternative view of the legally binding character of the JCPOA is based on both the content of its commitments - including that of lifting the UN sanctions against Iran - and its peculiar system of implementation. This position, which has not attracted much attention in the literature, has the merit of pointing to the difficulties in justifying a unilateral repudiation of the nuclear deal, given that, under Article 60 of the Vienna Convention on the Law of Treaties, the termination of a multilateral treaty as a consequence of a breach by one of its parties requires a concerted response by all other parties. ${ }^{77}$

Significantly, although the US Presidential Memorandum noted that "[i]n 2016, Iran also twice violated the JCPOA's heavy water stockpile limits," ${ }^{, 78}$ neither it nor the remarks of the US President ${ }^{79}$ identified any Iranian noncompliance with the JCPOA since the beginning of the Trump Administration.

It is to be noted that Iran developed an argument based on the contrariety of the US reimposition of sanctions with the JCPOA, as endorsed by UNSC Res. 2231 (2015), by qualifying US conduct as a serious breach of its legal obligations under the UN Charter. Iran's Ambassador to the UN ${ }^{80}$ affirmed the binding nature of paragraph 2 of Resolution 2231 (2015), in which the UNSC

calls upon all Members States, regional organizations and international organizations to take such actions as may be appropriate to support the implementation of the JCPOA, including by taking actions commensurate with the implementation plan set out in the JCPOA and this resolution and by refraining from actions that undermine implementation of commitments under the JCPOA.

That issue is also addressed by ad hoc Judge Momtaz in his declaration attached to the order on the request for provisional measures in the case of the Alleged violations of the 1955 Treaty of Amity, Economic Relations, and Consular Rights, in which he argued that

[i]t is absolutely clear from the opening of the resolution's operative part, immediately preceded by a reference in its preamble to Article 25 of the Charter, that the Security Council intended to establish binding obligations for all Member States, including the United States. ${ }^{81}$ 


\section{$V$. The effectiveness of the blocking regulation and other $\mathbf{E U}$ initiatives}

In the transatlantic confrontation on the reimposition of US sanctions, one of the most debated issues has been the effectiveness of the Blocking Regulation as a mechanism to offset the effects of reinstated US sanctions on Iran, at least from an economic or commercial point of view. ${ }^{82}$ Measures like blocking statutes generally: (1) forbid compliance with particular US extraterritorial sanctions; (2) provide for nonrecognition of judgments and administrative determinations that give effect to the sanctions; (3) establish a "clawback" cause of action for recovery of damages incurred for sanctions violations; and (4) require reporting of activity related to the sanctions. ${ }^{83}$

When the Trump Administration decided that it would no longer suspend Title III of the 1996 Helms-Burton Act, the EU announced that it would consider all options at its disposal to protect its legitimate interests, including through the use of the blocking statute:

The Statute prohibits the enforcement of US courts judgements relating to Title III of the Helms-Burton Act within the EU, and allows EU companies sued in the US to recover any damage through legal proceedings against US claimants before EU courts. ${ }^{84}$

Still, there has been a clear awareness among EU Member States that the new generation of US secondary sanctions, particularly those affecting financial transactions, are more robust and costly for EU corporate entities, in comparison with the situation existing in 1996, when the idea of a blocking regulation was conceived. ${ }^{85}$ The Vice-President of the European Commission, Valdis Dombrovskis, who was also in charge of financial stability, financial services, and the capital markets union, soon questioned the effectiveness of a revised Blocking Regulation, especially for banks, "given the international nature of the banking system and especially the exposure of large systemic banks to US financial system and US dollar transactions." ${ }^{86}$ As a matter of fact, the Blocking Regulation could do nothing to prevent financial institutions that engage in transactions with Iran from losing access to the US financial system.

In the period between May and November 2018, the Belgian-based Society for Worldwide Interbank Financial Telecommunication (SWIFT), which provides an international system for facilitating cross-border payments, faced the dilemma of choosing whether to comply with US sanctions or to adhere to the obligations under the EU Blocking Regulation. The Trump Administration clarified that "SWIFT would be subject to US sanctions if it provides financial messaging services to certain designated Iranian financial institutions." ${ }^{87}$ As the latest and most significant wave of sanctions against Iran came into effect, SWIFT eventually announced the suspension of several Iranian banks from its service, "in the interest of the stability and integrity of the global financial system": a decision criticized as "regrettable" by the European Commission. ${ }^{88}$ 
In a joint ministerial statement, the remaining parties to the JCPOA

welcomed practical proposals to maintain and develop payment channels, notably the initiative to establish a special purpose vehicle, to facilitate payments related to Iran's exports (including oil) and imports, which will assist and reassure economic operators pursuing legitimate business with Iran. ${ }^{89}$

After long discussions, France, the UK, and Germany, with help from the European Commission and the EEAS, launched a new mechanism for facilitating legitimate trade between European economic operators and Iran called the "Instrument in Support of Trade Exchanges" (INSTEX). The joint statement of the three foreign ministers made clear that the initial focus was "on the sectors most essential to the Iranian population - such as pharmaceutical, medical devices and agri-food good," and that its long term aim was to open up to "economic operators from third countries who wish to trade with Iran. ${ }^{" 90}$ High Representative Mogherini stressed that "INSTEX is not directed against the US. It will operate fully in line with EU and international law and standards on anti-money laundering or countering the financing of terrorism." At the time of writing, it is too early to assess the mechanism; it will seek to reduce the need for transactions between the European and Iranian financial systems by allowing European exporters to receive payments for sales to Iran from funds that are already within Europe, and vice versa. $^{91}$

\section{Conclusion}

The question of the legality of US secondary sanctions, as exorbitant measures having extraterritorial effects, needs to be understood against the background of the complexities in the implementation of the JCPOA. The convergence between the US and the EU in the period 2010-2012, when the European restrictive measures substantially mirrored the content of US sanctions, cannot be considered as expression of an overall acceptance of that type of measure. The challenge posed to the deal by the Trump Administration puts the EU in the uncomfortable position of "having to choose between its role as guardian of the JCPOA, protecting it from interpretative drift, and confronting the US on the issue of good faith in living up to its multilateral commitments." ${ }^{92}$ After the US withdrawal from the nuclear deal, the EU intended for the confrontation with the US to be held within the framework of international law: having affirmed the unlawful nature of certain sanctions reimposed by the US, the EU decided to update the 1996 Blocking Regulation as a form of countermeasure under international law. Its effectiveness risks to be undermined by the design of the new generation of secondary sanctions, particularly those affecting financial transactions and the banking sector in general. It remains that the issue of the jurisdictional scope of unilateral nonforcible measures needs to be assessed by taking into consideration the inherent tension between centralized sanctions and the autonomous measures outside of the institutional collective security regime. 


\section{Notes}

1 U.N. Doc. S/RES/2231 (2015).

2 Council of the European Union Press Release, "Declaration by the High Representative on Behalf of the EU Following US President Trump's Announcement on the Iran Nuclear Deal (JCPOA)," (May 9, 2018), available at <www.consilium.europa.eu/en/ press/press-releases/2018/05/09/declaration-by-the-high-representative-on-behalfof-the-eu-following-us-president-trump-s-announcement-on-the-iran-nuclear-dealjcpoa>.

3 Presidential Memorandum, "Ceasing U.S. Participation in the JCPOA and Taking Additional Action to Counter Iran's Malign Influence and Deny Iran All Paths to a Nuclear Weapon," (May 8, 2018), available at <www.whitehouse.gov/presidentialactions/ceasing-u-s-participation-jcpoa-taking-additional-action-counter-iransmalign-influence-deny-iran-paths-nuclear-weapon>.

4 President Donald Trump, "Executive Order Reimposing Certain Sanctions with Respect to Iran," (August 6, 2018), available at <www.whitehouse.gov/presidential-actions/ executive-order-reimposing-certain-sanctions-respect-iran>.

5 Commission Delegated Regulation (EU) 2018/1100 of June 6, 2018, amending the Annex to Council Regulation (EC) No 2271/96 protecting against the effects of extraterritorial application of legislation adopted by a third country, and actions based thereon or resulting therefrom, Official Journal L 199 I (August 7, 2018), p. 1.

6 See Habib Gherari and Sandra Szurek eds., Sanctions unilatérales, mondialisation du commerce et ordre juridique international - À propos des lois Helms-Burton et D'Amato-Kennedy (1998); Jeffrey A. Meyer, "Second Thoughts on Secondary Sanctions," University of Pennsylvania Journal of International Law, Vol. 30, No. 3 (2009), p. 905.

7 Council Regulation (EC) No 2271/96 of November 22, 1996, protecting against the effects of the extra-territorial application of legislation adopted by a third country, and actions based thereon or resulting therefrom, Official Journal L 309 (November 29, 1996), p. 1.

8 See Harry L. Clark, "Dealing with US Extraterritorial Sanctions and Foreign Countermeasures," University of Pennsylvania Journal of International Law, Vol. 20, No. 1 (1999), p. 61; John W. Boscariol, "At the Cross-Roads of US and Canadian Trade Controls: The Cuba Conflict," Global Trade and Customs Journal, Vol. 5, No. 6 (2010), p. 237.

9 See Michael P. Malloy, United States Economic Sanctions: Theory and Practice (2001).

10 Meyer, supra note 6, p. 926.

11 See Alexander Orakhelashvili, "The Impact of Unilateral EU Economic Sanctions on the UN Collective Security Framework: The Cases of Iran and Syria," in Ali Z. Marossi and Marisa R. Bassett eds., Economic Sanctions Under International Law (2015), p. 3.

12 Daniel H. Joyner, "UN Counter-Proliferation Sanctions and International Law," in Larissa van den Herik ed., Research Handbook on UN Sanctions and International Law (2017), p. 105.

13 Cf. Natalino Ronzitti, "Sanctions as Instruments of Coercive Diplomacy: An International Law Perspective," in Natalino Ronzitti ed., Coercive Diplomacy, Sanctions and International Law (Brill, Nijhoff, 2016), p. 1, at pp. 26-27.

14 See N. Jansen Calamita, "Sanctions, Countermeasures, and the Iranian Nuclear Issue," Vanderbilt Journal of Transnational Law, Vol. 42, No. 5 (2009), p. 1393; Sahib Singh, "Iran, The Nuclear Issue \& Countermeasures," EJIL:Talk! (January 10, 2012), available at $<$ www.ejiltalk.org/iran-the-nuclear-issue-countermeasures $>$.

15 For different positions on collective countermeasures, cf. Linos-Alexandre Sicilianos, "Countermeasures in Response to Grave Violations of Obligations Owed to the 
International Community," in James Crawford, Alain Pellet, and Simon Olleson eds., The Law of International Responsibility (2010), p. 1137; Martin Dawidowicz, ThirdParty Countermeasures in International Law (2017).

16 Cedric Ryngaert, Jurisdiction in International Law, 2nd ed. (2015), p. 116.

17 See Joy Gordon, "Extraterritoriality: Issues of Overbreadth and the Chilling Effect in the Cases of Cuba and Iran," Harvard International Law Journal Online, Vol. 57 (2016), p. 1.

18 Cedric Ryngaert, "Extraterritorial Export Controls (Secondary Boycotts)," Chinese Journal of International Law, Vol. 7, No. 3 (2008), pp. 625, 626.

19 See Vaughan Lowe, "The Problems of Extraterritorial Jurisdiction: Economic Sovereignty and the Search for a Solution," International and Comparative Law Quarterly, Vol. 34, No. 4 (1985), p. 724; moreover, Kenneth W. Abbott, "Defining the Extraterritorial Reach of American Export Controls: Congress as Catalyst," Cornell International Law Journal, Vol. 17, No. 1 (1984), p. 79.

20 Cuban Liberty and Democratic Solidarity (LIBERTAD) Act of 1996, Pub. L. No. 104-114, 110 Stat. 785, March 12, 1996.

21 Pub. L. 104-172, 110 Stat. 1541 (50 U.S.C. 1701), August 5, 1996.

22 Nigel D. White, The Cuban Embargo Under International Law (2015), p. 105; as for the -debate on the conformity of this piece of legislation with international law, see Brice M. Clagert, "Title III of the Helms-Burton Act Is Consistent with International Law," American Journal of International Law, Vol. 90, No. 3 (1996), p. 434; Brigitte Stern, "Vers la mondialisation juridique? Les lois Helms-Burton et d'AmatoKennedy," Revue générale de droit international public, Vol. 100, No. 4 (1996), p. 97; Vaughan Lowe, "US Extraterritorial Jurisdiction: The Helms-Burton and D'Amato Acts," International \& Comparative Law Quarterly, Vol. 46, No. 2 (1997), p. 378.

23 European Union-United States: Memorandum of Understanding Concerning the U.S. Helms-Burton Act and the U.S. Iran and Libya Sanctions Act, reproduced in International Legal Materials, Vol. 36, No. 3 (1997), p. 529. See Stefaan Smis and Kim Van der Borght, "The EU-U.S. Compromise on the Helms-Burton and D'Amato Acts," American Journal of International Law, Vol. 93, No. 1 (1999), p. 227.

24 Michael R. Pompeo, Remarks to the Press (Washington, DC, April 17, 2019), available at $<$ www.state.gov/secretary/remarks/2019/04/291174.htm>.

25 "Joint Statement by Federica Mogherini, Chrystia Freeland and Cecilia Malmström on the decision of the United States to further activate Title III of the Helms Burton (Libertad) Act," (April 17, 2019), available at <https://eeas.europa.eu/headquarters/ headquarters-homepage/61181/joint-statement-federica-mogherini-chrystia-freelandand-cecilia-malmstr $\% \mathrm{C} 3 \% \mathrm{~B} 6 \mathrm{~m}$-decision-united_en>.

26 U.N. Doc. A/RES/47/19 (1992); the last resolution, U.N. Doc. A/RES/73/8 (2018), was adopted by a recorded vote of 189 in favor to 2 against (Israel, United States), with no abstentions.

27 U.N. Doc. A/RES/73/167 (2019) on "Human rights and unilateral coercive measures," which strongly objects to the extraterritorial nature of those measures which threaten State sovereignty. See Hofer, supra note 8, p. 175.

28 See Barry E. Carter and Ryan M. Farha, "Overview and Operation of US Financial Sanctions, Including the Example of Iran," Georgetown Journal of International Law, Vol. 44, (2013), p. 903.

29 See "Developments in the Law - Extraterritoriality," Harvard Law Review, Vol. 124, No. 5 (2011), p. 1246, pp. 1255-1256.

30 See "Congress Enacts Sanctions Legislation Targeting Russia," American Journal of International Law, Vol. 111, No. 4 (2017), p. 1015.

31 See Michael Gruson, "The U.S. Jurisdiction Over Transfers of U.S. Dollars Between Foreigners and Over Ownership of US Dollar Accounts in Foreign Bans," Columbia Business Law Review, No. 3 (2004), p. 721. 
32 See Marija Đorđeska, "From Targeted Sanctions to Targeted Settlements: International Law-Making Through Effective Means," EJIL:Talk! (July 22, 2014), available at $<$ www.ejiltalk.org/from-targeted-sanctions-to-targeted-settlements-international-lawmaking-through-effective-means/>.

33 Gordon, supra note 17, p. 6.

34 International Crisis Group, Implementing the Iran Nuclear Deal: A Status Report (2017), available at <www.crisisgroup.org/middle-east-north-africa/gulf-and-arabianpeninsula/iran/173-implementing-iran-nuclear-deal-status-report>; moreover, John Changiz Vafai, "The New Era of Doing Business with Iran: Iran's International Commercial Transactions and Global Security," Pace International Law Review, Vol. 29, No. 1 (2017), p. 1. Ironically, in August 2017, a global business investigative and regulatory risk mitigation firm that provides due diligence services for various countries and their citizenship by investment programs has agreed to pay $\$ 259,200$ (USD) to settle what the OFAC identifies as violations of the sanctions program, in connection with due diligence of several individuals, including some Iranian nationals.

35 See FATF, Risk-Based Approach for the Banking Sector (2014), available at $<$ www.fatfgafi.org/publications/fatfrecommendations/documents/risk-based-approach-bankingsector.html>.

36 See Joel Schectman and Yeganeh Torbati, "New U.S. guidance on Iran sanctions seeks to reassure banks," Reuters, October 10, 2016, available at $<$ www.reuters.com/article/ us-iran-usa-sanctions-idUSKCN12A29Q>.

37 European Union, Guidelines on Implementation and Evaluation of Restrictive Measures (Sanctions) in the Framework of the EU Common Foreign and Security Policy, Doc. 5664/18 (May 4, 2018).

38 See, for instance, Council Regulation (EU) No. 401/2013 of May 2, 2013, concerning restrictive measures in respect of Myanmar/Burma and repealing Regulation (EC) No. 194/2008, Official Journal L 121 (May 3, 2013), p. 1. On the jurisdictional scope of the EU sanctions see Marco Gestri, "Sanctions Imposed by the European Union: Legal and Institutional Aspects," in Ronzitti ed., supra note 13, p. 70, at p. 79; Leonardo Borlini and Stefano Silingardi, "Defining Elements and Emerging Legal Issues of EU 'Sanctions',' Italian Yearbook of International Law Vol. 27 (2018), p. 33, at pp. 40-41.

39 EU Guidelines, supra note 38, para. 54.

40 Cf. Christina Eckes, "The Law and Practice of EU Sanctions," in Steven Blockmans and Panos Koutrakos eds., Research Handbook on the EU's Common Foreign and Security Policy (2018) p. 206, at p. 217.

41 See Elin Hellquist, "Either with Us or against Us? Third-Country Alignment with EU Sanctions against Russia/Ukraine," Cambridge Review of International Affairs Vol. 29, No. 3 (2016), p. 997.

42 See Baldur Thorhallsson, "Iceland's Alignment with the EU - US Sanctions on Russia: Autonomy v. Dependence," Global Affairs, Vol. 3, No. 3 (2017), p. 307.

43 Gestri, supra note 39, p. 79.

44 Tom Ruys, "Sanctions, Retortions and Countermeasures: Concepts and International Legal Framework," in van den Herik ed., supra note 12, p. 19, at p. 28.

45 See Bernard H. Oxman, "Jurisdiction of States," in Rudiger Wolfrum ed., Max Planck Encyclopedia of Public International Law, Vol. VI (2012), p. 546; Frederick Alexander Mann, "The Doctrine of Jurisdiction in International Law," Recueil des Cours, Vol. 111 (1964), p. 1; moreover see "Extraterritorial Jurisdiction," in Yearbook of International Law Commission, Vol. II, Part Two (2006), p. 229.

$46 C f$. Andrea Bianchi, "Extraterritoriality and Export Controls: Some Remarks on the Alleged Antimony between European and US Approaches," German Yearbook of International Law, Vol. 35 (1992), p. 366, at p. 368.

47 Charlotte Beaucillon, "Practice Makes Perfect, Eventually? Unilateral State Sanctions and the Extraterritorial Effects of National Legislation," in Ronzitti ed., supra note 13, p. 103, at p. 106. 
48 Nigel D. White, "Autonomous and Collective Sanctions and the International Legal Order," Italian Yearbook of International Law, Vol. 27 (2017), p. 3, at p. 14. In addition, for a radical position on the tension between extraterritorial sanctions and competences of the UN Security Council, see Report of the Special Rapporteur on the negative impact of unilateral coercive measures on the enjoyment of human rights, U.N. Doc. A/72/370 (August 29, 2017), p. 19, para. 55: "the enactment of domestic legislation with purported extraterritorial reach, resulting in a de facto "multilateralization" of unilateral coercive measures, could be seen as infringing on the competences of the Security Council. . . . It is thus highly questionable that any State should take upon itself to impose sanctions that apply worldwide "without borders," without any justifiable right to exercise universal jurisdiction, which is in the purview solely of the Security Council."

49 Case of the "S.S. Lotus" (France v. Turkey) (1927) P.C.I.J., Ser. A, No. 10, p. 18.

50 See, generally, Maziar Jamnejadand Michael Wood, "ThePrinciple of Non-Intervention," Leiden Journal of International Law, Vol. 22, No. 2 (2009), p. 345.

51 Cf. Ryngaert, supra note 16, p. 101; Alex Mills, "Rethinking Jurisdiction in International Law," British Yearbook of International Law, Vol. 84 (2014), p. 187; moreover, see Susan Emmenegger, "Extraterritorial Economic Sanctions and their Foundation in International Law," Arizona Journal of International \& Comparative Law, Vol. 33, No. 3 (2016), p. 631.

52 "Barcelona Traction, Light and Power Company, Limited (Belgium v. Spain) (New Application: 1962)" I.C.J. Reports 1970, Judgment (February 5, 1970), pp. 3, 37: “The concept and structure of the company are founded on and determined by a firm distinction between the separate entity of the company and of the shareholder."

53 Cf. Andreas F. Lowenfeld, "Congress and Cuba: The Helms-Burton Act," American Journal of International Law, Vol. 90, No. 3 (1996), p. 419.

54 Ryngaert, supra note 16, p. 118.

55 General Agreement on Tariffs and Trade, United Nations Treaty Series, Vol. 1867, p. 187.

56 See Andrew D. Mitchell, "Sanctions and the World Trade Organization," in van den Herik ed., supra note 12, p. 283, at p. 300, and the authors quoted therein; moreover, see Brigitte Stern, "Can the United States set Rules for the World? - A French View," Journal of World Trade, Vol. 31, No. 4 (1997), p. 5. On the margin of discretion that States possess in determining what is necessary for the protection of essential security interests when they invoke the exception, see Michael Bothe, "Compatibility and Legitimacy of Sanctions Regimes," in Ronzitti ed., supra note 13, p. 33, at p. 35.

57 Meyer, supra note 6, p. 909.

58 Beaucillon, supra note 48, p. 105.

59 See European Commission, Explanatory Memorandum: Commission delegated regulation of 6.6.2018 amending the annex to Council regulation No. 2271/96 of 22 November 1996 protecting against the effects of extra-territorial application of legislation adopted by a third country, and actions based thereon or resulting therefrom (June 6, 2018), Doc. C (2018) 3572 final, para. 1.

60 European Commission, Guidance Note - Questions and Answers: adoption of update of the Blocking Statute, C/2018/5344, Official Journal C 277I (August 7, 2018), p. 4.

61 U.N. Doc. S/RES/1929 (2010).

62 Council Decision 2010/413/CFSP of July 26, 2010, concerning restrictive measures against Iran and repealing Common Position 2007/140/CFSP, Official Journal L 195 (July 27, 2010), p. 39. See Pierre-Emmanuel Dupont, "Countermeasures and Collective Security: The Case of the EU Sanctions Against Iran," Journal of Conflict and Security Law, Vol. 17, No. 3 (2012), p. 301.

63 For an analysis of the factors influencing the convergence of EU-US sanction policies against Iran in the period 2006-2012, see Sascha Lohmann, "The Convergence 
of Transatlantic Sanction Policy against Iran," Cambridge Review of International Affairs, Vol. 29, No. 3 (2016), p. 930.

64 Council Decision 2012/35/CFSP of January 23, 2012 amending Decision 2010/413/ CFSP concerning restrictive measures against Iran, Official Journal L 19 (January 24, 2012), p. 22.

65 Council Regulation (EU) No 267/2012 of March 23, 2012, concerning restrictive measures against Iran and repealing Regulation (EU) No 961/2010, Official Journal L 88 (March 24, 2012), p. 1.

66 "Developments in the Law - Extraterritoriality," supra note 29, p. 1251; Quentin Genard, "European Union Responses to Extraterritorial Claims by the United States: Lessons from Trade Control Cases," Non-proliferation Paper, No. 3 (2014), available at <www.nonproliferation.eu/european-union-responses-to-extra-territorial-claimsby-the-united-states-lessons-from-trade-control-cases-2/>.

67 Ryngaert, supra note 16, p. 119.

68 See "BNP Paribas Expects 'Heavy Penalty' for Sanctions Violations," The Guardian, June 30, 2014, available at <www.theguardian.com/business/2014/jun/30/ bnp-paribas-fine-penalty-sanctions $>$.

69 EU Council Conclusion on Iran, 3142th Foreign Affairs Council meeting (January 23, 2012), para. 2.

70 Cf. U.N. Security Council, Verbatim Record (November 25, 2014), U.N. Doc. S/ PV/7323; U.N. Security Council, Verbatim Record (February 11, 2016), U.N. Doc. S/ $\mathrm{PV} / 7620$.

71 See Jean Galbraith, "Ending Security Council Resolutions," American Journal of International Law, Vol. 109, No. 4 (2015), pp. 806, 809.

72 On the introduction specific clauses to allow companies to exit contracts without any claims for damages in case the sanctions landscape deteriorates, see Andrea Atteritano and Maria Beatrice Deli, “An Overview of International Sanctions' Impact on Treaties and Contracts," in Ronzitti ed., supra note 13, p. 207.

73 "Remarks by President Trump on Iran Strategy," (October 13, 2017), available at $<$ www.whitehouse.gov/briefings-statements/remarks-president-trump-iran-strategy/>.

74 See Daniel H. Joyner, Iran's Nuclear Program and International Law: From Confrontation to Accord (2016), p. 228; "Contemporary Practice of the US: Agreement on Iran Nuclear Program Goes into Effect," American Journal of International Law, Vol. 109, No. 4 (2015), p. 874.

75 "Remarks by HR/VP Mogherini on the statement by US President Trump regarding the Iran nuclear deal (JCPOA),"'(May 8, 2018), available at $<$ https://eeas.europa.eu/delegations/ iran/44238/remarks-hrvp-mogherini-statement-us-president-trump-regardingiran-nuclear-deal-jcpoa_en>.

76 Cf. Enzo Cannizzaro, "Editorial: The Iran Nuclear Deal and the Future of the European Foreign Policy," European Papers, Vol. 3, No. 1 (2018), p. 3.

77 Ibid.

78 Presidential Memorandum, supra note 3.

79 Donald J. Trump, "Remarks on the Joint Comprehensive Plan of Action to Prevent Iran from Obtaining a Nuclear Weapon and an Exchange with Reporters," White House Office of the Press Secretary (May 8, 2018).

80 Gholamali Khoshroo, "Trump's Sanctions Against Iran Are a Clear Breach of International Law," Guardian (August 8, 2018), available at <www.theguardian.com/ commentisfree/2018/aug/08/donald-trump-sanctions-iran-international-law $>$.

81 Declaration of ad hoc Judge Momtaz, unofficial translation, available at $<$ www.icj-cij. org/files/case-related/175/175-20181003-ORD-01-02-EN.pdf $>$.

82 For a rare invocation of the EU Blocking Statute, see the press statement of the Government of Gibraltar with respect to a US request for the seizure of the Iranian oil tanker: "Further Mutual Legal Assistance Requests from the United States of America," Press 
Release No. 604/2019 (August 18, 2019), available at <https://www.gibraltar.gov. gi/press-releases/further-mutual-legal-assistance-requests-from-the-united-states-ofamerica-6042019-5198>.

83 Clark, supra note 8, p. 82. More recently, see Charlotte Van Haute, Sara Nordin, and Genevra Forwood, "The Reincarnation of the EU Blocking Regulation: Putting European Companies Between a Rock and a Hard Place," Global Trade and Customs Journal, Vol. 13, Nos. 11-12 (2018), p. 496.

84 Joint Statement by Federica Mogherini and Cecilia Malmström on the Decision of the United StatestoFurtherActivateTitleIIIoftheHelmsBurton(Libertad)Act(April17,2019), available at $<$ https://eeas.europa.eu/headquarters/headquarters-homepage/61183/jointstatement-federica-mogherini-and-cecilia-malmstr\% $\% 3 \% \mathrm{~B} 6 \mathrm{~m}$-decision-united-statesfurther en>.

85 See also Daniel Franchini, “'With Friends Like That, Who Needs Enemies?' Extraterritorial Sanctions Following the United States' Withdrawal from the Iran Nuclear Agreement," EJIL:Talk! (May 29, 2018), available at <www.ejiltalk.org/withfriends-like-that-who-needs-enemies-extraterritorial-sanctions-following-the-unitedstates-withdrawal-from-the-iran-nuclear-agreement/>.

86 See "EU Says Block on U.S. Sanctions on Iran of Limited Use for EU Banks," Reuters (May 17, 2018), available at <www.reuters.com/article/us-iran-nuclear-eu-banks/eusays-block-on-us-sanctions-on-iran-of-limited-use-for-eu-banks-idUSKCN1II17K>.

87 "Briefing on Iran Sanctions: Michael R. Pompeo, Secretary of State, Secretary of the Treasury Steven T. Mnuchin," (November 2, 2018), available at <www.state.gov/ secretary/remarks/2018/11/287090.htm>.

88 "EU Says SWIFT Decision on Iran Banks Regrettable," Reuters (November 7, 2018), available at <www.reuters.com/article/us-usa-iran-swift-commission/eu-says-swiftdecision-on-iran-banks-regrettable-idUSKCN1NC1I1>.

89 Implementation of the Joint Comprehensive Plan of Action: Joint Ministerial Statement, New York (September 24, 2018), available at <https://eeas.europa.eu/headquarters/ headquarters-homepage/51036/implementation-joint-comprehensive-plan-actionjoint-ministerial-statement_en $>$.See"EU and US Sanctions, which Sovereignty?" Policy Paper No. 232, Notre Europe (October 13, 2018), available at $<$ http://institutdelors.eu/ publications/leurope-face-aux-sanctions-americaines-quelle-souverainete/?lang=en $>$.

90 Press release: "New Mechanism to Facilitate Trade With Iran: Joint Statement," (January31,2019), availableat $<$ www.gov.uk/government/news/joint-statement-on-the-newmechanism-to-facilitate-trade-with-iran>.

91 See Ellie Geranmayeh and Esfandyar Batmanghelidj, "Trading With Iran via the Special Purpose Vehicle: How it Can Work," European Council on Foreign Relations (February 7, 2019), available at <www.ecfr.eu/article/commentary_trading_with_iran_ special_purpose_vehicle_how_it_can_work $>$.

92 Steven Blockmans and Astrid Viaud, "EU Diplomacy and the Iran Nuclear Deal: Staying Power?" CEPS Policy Insight, No. 2017-2028 (July 14, 2017), p. 12, available at $<$ www.ceps.eu/publications/eu-diplomacy-and-iran-nuclear-deal-staying-power>. 


\section{Part II}

\section{Implementation of sanctions}




\title{
5 History of implementation of sanctions
}

\author{
Jean-Marc Thouvenin
}

\section{Introduction}

There is no doubt that international economic sanctions have become a contemporary day-to-day practice, especially for super(economic) powers like the United States of America and the European Union. This has been recently illustrated by the case brought before the ICJ by Iran against the United States in the Alleged Violations of the 1955 Treaty of Amity, Commerce and consular rights case. It reveals that some actors of the international relations have a peculiar understanding of the meaning of the principles of equal sovereignty of States and of noninterference. ${ }^{1}$

But international economic sanctions are definitely not a new tool in international relations. While it is true that such tool has probably never been used as intensively as it has been since the 1990s, the practice finds its roots in ancient times, and the recourse to it has been regular throughout the ages. This is what will be shown in this contribution, which follows a chronological outline, referring briefly to what was the practice before the twentieth century (Section I), then turning to the one between the World War I and the adoption of the UN charter (Section II), then to the practice as it developed since the adoption of the UN Charter (Section III).

\section{Before the twentieth century}

The first historically recorded international economic sanction dates back to 432 B.C., when Pericles, the ruler of Athens, adopted a decree prohibiting the importation and selling at Athens's markets of products originating from Megara, as a retaliation after the kidnapping of three women. ${ }^{2}$ But this oft-cited example is just one among many.

Indeed, a look at the oldest ages reveals that economic asphyxiation has been a classic warfare practice. Vercingetorix, the King of the Francs, was defeated by Cesar after the famous siege of the fortified settlement of Alesia. Locked in their fortress and deprived of any food supply, the Francs understood that they had no other option than to surrender.

One could also mention that in the 1760s the American colonies adopted economic sanctions - in the form of a boycott - against English merchants to force 
England to change its rules applicable to the Colonies in matters of taxation and trade, known as the "Townshend Acts." " A few years later, in 1806, the continental blockade was imposed and decreed by Napoleon to weaken England, ${ }^{4}$ followed by the American embargoes decided by Thomas Jefferson, in force between 1807 and 1813, aimed at blocking all trade with foreigners (Embargo Act, 1807, NonIntercourse Act, 1809, Non-Import Act, 1811).

In the beginning of the twentieth century the practice of economic sanctions took the form of private calls for boycotts. It was the case with Chinese boycotts launched between 1905 and 1931. ${ }^{5}$ The first was initiated by the Shanghai Chamber of Commerce in response to the anti-Chinese United States policy. ${ }^{6}$ The following were launched against Japanese products. The first of them was launched in 1908 and lasted nine months, after the Tatsu-Maru Affair concerning the unlawful seizure by China of a Japanese steamer by a Chinese gunboat. The strong reaction of Japan generated a reaction in the Chinese people in the form of a boycott against Japanese goods. The second, from August to October 1909, was the consequence of the Antung-Mukden Railway dispute. The Japanese government engaged in construction work on the railway line between Antung and Mukden, as foreseen by the Peking Treaty of 1905. Finally, the Viceroy of Manchuria issued an order prohibiting the anti-Japanese boycott after acknowledging that Japan was only exercising its treaty rights. The third occurred from May to October 1915, and it was designed to put pressure on Japan for negotiating concession. The fourth occurred from May to December 1919, as a reaction to the Chinese failure during the Versailles Peace Conference of 1919 to obtain the nullification of the Sino-Japanese Treaty of 1915. The fifth operated from April to August 1923, as an angry reaction to the rejection by Japan of a Chinese request for recovering Port Arthur and Dairen. The sixth, seventh, eighth, and ninth occurred respectively from May to November 1925, March to April 1927, May 1928 to April 1929, and 1931-1932; they were the outcome of nationalist and anti-Japanese movements. ${ }^{7}$

\section{From World War I to the UN charter}

It is no surprise that the economic weapon has also been of use during the World Wars, but the practice took an elaborate turn in the context of World War I.

In France, a decree of September 27, 1914, prohibited all trade with the subjects of enemy States and nullified every contract concluded with a subject of the enemy since the outbreak of the war. Later, France reinforced these sanctions in response to the decisions taken by Germany and Austria to cancel all contracts concluded with foreigners from enemy countries, including those concluded before the war, and to freeze or confiscate all their goods.

Great Britain adopted the Trading with the Enemy Act on September 18, 1914, prohibiting any business relationship with persons considered to be nationals of an enemy State. This law also provided that property belonging to such persons would be seized and placed under the supervision of the State. The application of this law has not been without difficulty. For example, it was queried whether Continental Tire and Rubber Co (GB) Ltd, a company whose shares were owned 
by a German resident, and whose directors were all German residents, was to be considered an "enemy," forbidding any English entity to honor any payment to it, despite the fact that it was an English company since it has been registered under British laws. This question was brought to the House of Lords, which decided that it was necessary in such case to "lift the corporate veil" and to consider that the personality of the German shareholder and directors of the company must be deemed confused with that of the otherwise British company from the point of view of the Trading with the Enemy Act, and therefore to treat it as if it were a German company. ${ }^{8}$ This decision opened the door to a general practice going in the same sense ${ }^{9}$ where a company's "corporate veil" can be lifted. This has been echoed by the International Court of Justice in the Barcelona Traction Light and Power Company case, when it recalled that:

enemy-property legislation was an instrument of economic warfare, aimed at denying the enemy the advantages to be derived from the anonymity and separate personality of corporations. Hence the lifting of the veil was regarded as justified ex necessitate and was extended to all entities which were tainted with enemy character, even the nationals of the State enacting the legislation. ${ }^{10}$

The first United States Trading with the Enemy Act dates back to the United States' entry into the war, which was in 1917. This law gives the President of the United States the power to limit any trade with enemies of the United States in times of war and to adopt other sanctions against those persons. ${ }^{11}$ Many goods belonging to Germans, and German companies, were seized on this basis during the war. ${ }^{12}$

After World War I, some prominent leaders began to think that the economic weapon that was commonly associated with other means of war could in fact simply replace all of them and thus be an alternative to the use of material force. Woodrow Wilson, the US President, did indeed praise the use of economic weapons rather than other weapons of war. In an address devoted to convincing the American people of the need to join the League of Nations - which failed since the US never became a member - Wilson noted:

A nation that is boycotted is a nation that is in sight of surrender. Apply this economic, peaceful, silent, deadly remedy and there will be no need for force. It is a terrible remedy. It does not cost a life outside the nation boycotted, but it brings a pressure upon the nation which, in my judgment, no modern nation could resist. ${ }^{13}$

This coercive technique was then "legally codified" as relevant in international relations by Article 16, para. 1, of the Covenant of the League of Nations, according to which:

Should any Member of the League resort to war in disregard of its covenants under Articles 12, 13 or 15, it shall ipso facto be deemed to have committed an 
act of war against all other Members of the League, which hereby undertake immediately to subject it to the severance of all trade or financial relations, the prohibition of all intercourse between their nationals and the nationals of the covenant-breaking State, and the prevention of all financial, commercial or personal intercourse between the nationals of the covenant-breaking State and the nationals of any other State, whether a Member of the League or not.

This provision remained unapplied because, as the United States had not joined the League, its implementation could not have any decisive effect. ${ }^{14}$ For example, the economic sanctions provided for by the Covenant of the League of Nations were simply not decided by its members against Japan following the invasion of Manchuria in 1931. By contrast, they were adopted against Italy as a result of the invasion of Ethiopia by Mussolini's troops in 1935, but they proved ineffective.

As we know, nothing prevented the World War II, during which economic sanctions were again applied between enemies. Since the end of World War II, economic sanctions became a common tool of international policy.

\section{Since the UN charter}

Since 1945, the practice of economic sanctions developed both (1) inside and (2) outside the UN.

\section{The United Nations'practice}

The United Nations Charter gives the Security Council the ability to adopt economic sanctions in order to give effect to its decisions adopted in application of Chapter VII, that is, in case of a threat to the peace, breach of the peace, or act of aggression. Article 41 of the Charter reads:

The Security Council may decide what measures not involving the use of armed force are to be employed to give effect to its decisions, and it may call upon the Members of the United Nations to apply such measures. These may include complete or partial interruption of economic relations and of rail, sea, air, postal, telegraphic, radio, and other means of communication, and the severance of diplomatic relations.

This provision has been rarely used before 1990, apart from the cases of Southern Rhodesia and South Africa. By contrast, the Security Council is very active in terms of economic sanctions since 1990, so much so that the 1990s have been dubbed the Sanctions Decade. ${ }^{15}$ During the last decades, the Security Council has imposed sanctions against Iraq (invasion of Kuwait), ${ }^{16}$ Yugoslavia (serious violations of humanitarian law), ${ }^{17}$ Somalia (internal conflict and humanitarian issues), ${ }^{18}$ Libya (international terrorism), ${ }^{19}$ Angola (the embargo targeted specifically UNITA opposed to the Angolan government), ${ }^{20}$ Haiti (coup), ${ }^{21}$ Rwanda (genocide), ${ }^{22}$ Sierra Leone (coup), ${ }^{23}$ Afghanistan (Taliban's regime), ${ }^{24}$ the DRC 
(internal conflict), ${ }^{25}$ Liberia (internal conflict), ${ }^{26}$ Sudan (internal conflict), ${ }^{27}$ Lebanon (political assassination), ${ }^{28}$ North Korea (nuclear proliferation), ${ }^{29}$ Eritrea (threatening international security and support for terrorism), ${ }^{30}$ and Iran (nuclear proliferation). ${ }^{31}$

Another shift in UN practice is worth mentioning. When the UN began to have regular recourse for economic sanctions, it was under the assumption that these sanctions should asphyxiate the target State, consistent with Wilson's doctrine recalled previously. But the embargo imposed on Iraq by Resolution 661 (1990) proved highly controversial since it was not Saddam Hussein's regime but rather, the Iraqis, which were dramatically hurt. In the mid-1990s, the unacceptable damages caused to innocent people by this sort of UN sanction were denounced in multiple forums. ${ }^{32}$ It was notably argued that "the sanctions upon Iraq have produced a humanitarian disaster comparable to the worst catastrophes of the past decades." ${ }^{33}$ The UN Secretary-General stated in his millennium report that:

When robust and comprehensive economic sanctions are directed against authoritarian regimes, a different problem is encountered. Then it is usually the people who suffer, not the political elites whose behavior triggered the sanctions in the first place. Indeed, those in power, perversely, often benefit from such sanctions by their ability to control and profit from black market activity, and by exploiting them as a pretext for eliminating domestic sources of political opposition. ${ }^{34}$

The UN had to change its approach and better target those responsible for the acts triggering the sanctions while sparing innocent people. This idea is at the core of the "Smart Sanction Movement," 35 which proved quite successful in imposing a new practice. Since then the UN economic sanctions focus on specific targets and aim at producing a limited, but expected, effect, with limited or no "collateral damages." Indeed, in many cases only an arms embargo is decided in order to reduce the level of violence in the country concerned. ${ }^{36}$ An economic ban may also be limited to certain products like diamonds, wood, or oil, for example. It has also become the practice of the Security Council to decide sanctions that affect only the members of a government and their supporters, or persons supposed to be terrorists or their supporters.

Yet, UN "smart sanctions" are subject to critics. Quite often it is claimed that they simply do not work, but the most important critic is that the basic human rights of individuals sanctioned by the UN Security Council are at best disrespected. The latter is obviously not equipped to enquire seriously on the activities of individuals accused by States' intelligence agencies of terrorism, financing terrorism, or traffic in weapons of mass destruction, and it must rely entirely on the information provided by UN Member States, which are often scarce. In any event, they cannot be verified by the UN, and in many case they cannot be disclosed to the sanctioned persons because they are classified. Consequently, it happened that individuals were sanctioned without knowing why and without being offered any opportunity to present a defense. This sort of practice is even more unacceptable 
since it comes from the UN, which is supposed to be a human rights champion. Under the pressure of the European Union after the Kadi Judgement, the Security Council decided to nominate an ombudsperson in charge with checking the complaints brought by sanctioned persons. ${ }^{37}$ However, this does not resolve the problem, since human rights law imposes a right to access to an independent tribunal, which an ombudsperson is not.

\section{Economic sanctions adopted outside the UN}

The practice of inflicting economic damages is not the monopoly of the UN. To the contrary, it has been increasingly used by States unilaterally.

The Arab States were the first to resort to an economic boycott as a primary international policy at the end of World War II. They proclaimed in 1945 a boycott on goods that was produced by the Jewish community in Palestine, and they then extended the boycott to Israeli products when the state of Israel was proclaimed. ${ }^{38}$ The boycott has long remained in force until it gradually has faded since the late 1980s.

The USSR and its Easter European allies also had recourse, through the COMECON, to a boycott on all trade with Yugoslavia in 1948 as a result of the political rupture between Stalin and Tito. The sanction continued until relations were normalized between the two Parties in 1955. ${ }^{39}$

In 1951, the British Government had recourse to the economic weapon, in response to the nationalization by Mossadegh, the Iran's nationalist prime minister, of the Anglo-Iranian Oil Company, an oil company which was controlled until then by British persons. A complete boycott of Iranian products was enacted as a retaliation, coupled with measures to freeze Iranian assets located in Britain. The Mossadegh regime was thrown out of power only three years later, ${ }^{40}$ but it was not a consequence of the British boycott. It is now documented that this was the outcome of a coup organized by the CIA and the MI6, as acknowledged by the United States in 2013.

One must for sure mention the United States, which is rightly seen as being particularly active in the field of economic sanctions since the end of World War II. For example, the US Government used the economic weapon against the communist bloc and China during the Cold War period, especially prohibiting any export of sensitive technologies. ${ }^{41} \mathrm{Cuba}$, under United States sanctions since $1962,{ }^{42}$ is also an emblematic example of the United States' policy, which has also been illustrated with regard to Nicaragua at the time of the Sandinista regime. An account of the latter can be found in the 1986 International Court of Justice Judgment in the Military and paramilitary activities in and against Nicaragua case, in which the American economic sanctions against Nicaragua are detailed and legally assessed. ${ }^{43}$ It should also be noted that after the USSR's invasion of Afghanistan in 1979, the United States issued a cereal embargo on the Soviet Union then ruled by Premier Leonid Brezhnev. This "food weapon" proved ineffective, as have been the sanctions against Cuba and Nicaragua, since the USSR then turned to European and other countries rather than the US to satisfy its grain 
needs. ${ }^{44}$ Despite the quite disputable success of this kind of policy, the United States have recourse to economic sanctions in its international relations since World War II.

The European Union has also been applying economic sanctions for a number of years as an international policy tool, not only pursuant to the decisions of the Security Council - which is not without its problems in the internal law of the Union, as is evidenced by the famous Kadi judgment ${ }^{45}$ - but also independently of the United Nations. One of the first cases for adoption of such a unilateral economic sanction regime dates back to the one adopted in 1982, against Argentina in the context of the Falklands War. ${ }^{46}$ These sanctions, taken at that time by what was still the European Economic Community on the basis of Article 113 of the EEC Treaty, which did not clearly empower the community to take action, ${ }^{47}$ had aroused concern on the part of the Organization of the American States. But these sanctions were withdrawn quickly, as soon as the Falklands war ended. Today the European Union clearly has the power to adopt decisions providing for the interruption or reduction of economic relations with third countries, pursuant to Chapter 2 of Title V of the Treaty on European Union. These decisions must be adopted by EU members unanimously. The practical implementation of these measures takes the form of regulations and implementing regulations adopted pursuant to Article 215 of the Treaty on the Functioning of the European Union. Nowadays the European Union applies multiple economic sanctions regimes against many States, including Russia since the annexation of Crimea.

The Organization of American States also adopts economic sanctions. This was the case in 1960 against the Dominican Republic, and in 1962 and 1964 against Cuba. This was also the case between 1991 and 1996 against Haiti following the overthrow of the then government by a military coup.

\section{Conclusion}

In sum, one can indeed consider that the current international economic landscape is one where economic sanctions are "everywhere" since "everyone" has recourse to them in international relations. Even if, as we have seen, they are rooted in the most ancient international practice, especially in times of war, they now take many forms in times of peace - directed against States as such - or against persons belonging or close to governments, or opposed to them, as is the case with terrorists and their supporters. They inflict trade, financial, or monetary damages, with the aim of putting pressure on the target State or persons for convincing it or them to act or not act in a certain manner. Their consistency with international law, which is not the topic of this contribution, must of course be assessed in light of treaty law and human rights law, and also with general international law. In this regard, one basic point is that in principle a sovereign State is fully entitled to decide how to manage its own economic relations with other States. However, the so-called "secondary sanctions" appear far less acceptable. ${ }^{48}$ Their object is to force foreign persons that are not under the jurisdiction of the sanctioning State to cease any economic relation with the target State. Such secondary sanctions 
are not common ${ }^{49}$ but have been unilaterally decided in some cases, and quite frequently by the United States. ${ }^{50}$ Since their clear aim is to interfere with the external relations of other States, they are often denounced as contrary to international law by the United Nations General Assembly or others. ${ }^{51}$

\section{Notes}

1 See, e.g., U.N. Doc. A/HRC/RES/24/14 (October 8, 2013), adopted by the UN Human Rights Council, para. 3.

2 Barry E. Carter, "International Economic Sanctions: Improving the Haphazard U.S. Legal Regime," California Law Review, Vol. 75 (1987), p. 1159, p. 1168, fn 18; De Gary C. Hufbauer, Jeffrey J. Schott, Kimberly Ann Elliott, and Barbara Oegg, Economic Sanctions Reconsidered, 3rd ed. (Peterson Institute for International Economics, 2007), p. 9.

3 M. Rathbone, P. Jeydel, and A. Lentz, "Sanctions, Sanctions Everywhere: Forging a Path Through Complex Transnational Sanctions Law," Georgetown Journal of International Law, Vol. 44 (2013), pp. 1055, 1063.

4 C. Calvo, Dictionnaire Manuel de Diplomatie et de Droit International Public et Privé, édition de 1885 rééditée en 2009 , p. 475, p. 53.

5 C.C. Joyner, "The Transnational Boycott as Economic Coercion in International Law: Policy, Place, and Practice," Vanderbuilt Journal of Transnational Law, Vol. 17 (1984), pp. 205-286, at pp. 210-212.

6 Delber L. McKee, "The Chinese Boycott of 1905-1906 Reconsidered: The Role of Chinese Americans," Pacific Historical Review, Vol. 55, No. 2 (1986), pp. 165-191; Shih-shan H. Ts'ai, "Reaction to Exclusion: The Boycott of 1905 and Chinese National Awakening," The Historian, Vol. 39, No. 1 (1976), pp. 95-110; Sin Kiong Wong, China's Anti American Boycott Movement in 1905: A Study in Urban Protest (2002), p. 232.

7 See The Osaka Chamber of Commerce and Industry, A Synopsis of the Boycott in China (1932), Trinity College Library, Moore Collection, available at $<$ https://digitalrepository.trincoll.edu/cgi/viewcontent.cgi?article=1041\&context=mooreSin Kiong WONG>.

8 M. Diez de Velasco, "La protection diplomatique des sociétés," Collected Courses of The Hague Academy of International Law, Vol. 141 (1974), p. 123. See also H.F. van Panhuys, The Role of Nationality in International Law (1959), pp. 109-125.

9 Ibid.

10 "Barcelona Traction, Light and Power Company, Limited," Judgment, February 5, 1979, I.C.J. Reports 1970, pp. 3, 40, para. 60.

11 C. Anderson, "The Trading-with-the-Enemy Act," American Journal of International Law, Vol. 12, No. 2 (1918), pp. 363-369; Carter, supra note 2, p. 1230.

12 D.A., Gross, "The U.S. Confiscated Half a Billion Dollars in Private Property During WWI: America's Home Front was the Site Of Internment, Deportation, and Vast Property Seizure," Smithsonian.com (July 28, 2014), available at <www.smithsonianmag.com/ history/us-confiscated-half-billion-dollars-private-property-during-wwi-180952144/>.

13 See, for a reference to this often cited speech, e.g., Carter, supra note 2, p. 1169, fn. 20.

14 See, on this provision as envisaged up to 1932, E. Clark, Boycotts and Peace: A Report by the Committee on Economic Sanctions (1932).

15 David Cortright and George A. Lopez, The Sanctions Decade: Assessing UN Strategies in the 1990s (2000).

16 U.N. Doc. S/RES/661 (1990).

17 U.N. Doc. S/RES/713 (1991).

18 U.N. Doc. S/RES/733 (1992). 
19 U.N. Doc. S/RES/748 (1992).

20 U.N. Doc. S/RES/864 (1993).

21 U.N. Doc. S/RES/873 (1993).

22 U.N. Doc. S/RES/1918 (1994).

23 U.N. Doc. S/RES/1132 (1997).

24 U.N. Doc. S/RES/1267 (1999).

25 U.N. Doc. S/RES/1493 (2003).

26 U.N. Doc. S/RES/1521 (2003).

27 U.N. Doc. S/RES/1591 (2005).

28 U.N. Doc. S/RES/1636 (2005).

29 U.N. Doc. S/RES/1718 (2006).

30 U.N. Doc. S/RES/1907 (2009).

31 U.N. Doc. S/RES/1737 (2006).

32 See J. Gordon, "Smart Sanctions Revisited," Ethics \& International Affairs, Vol. 25, No. 3 (2011), pp. 317-318.

33 M. Bossuyt, "The Adverse Consequences of Economic Sanctions, Economic and Social Council," U.N. Doc. E/CN.4/Sub.2/2000/33, para. 63.

34 Millennium Report of the Secretary-General of the United Nations, "We the Peoples": The Role of the United Nations in the 21st Century (2000), p. 50.

35 This is taken from Gordon, supra note 32, p. 318.

36 This sort of sanction can also be damaging. If one of the opponents is better armed than the other, an arms embargo can be at its advantage and leave the other opponent without sufficient defense capacity. For example, during the siege of Sarajevo, the arms embargo imposed by the UN Security Council enhanced the disequilibrium between the Serbian and the Muslim forces. On this precise point, Sir Elihu Lauterpacht wrote a separate opinion in the Application of the Convention on the Prevention and Punishment of the Crime of Genocide (Bosnia and Herzegovina v. Serbia and Montenegro) case in which he stated: "95. The fourth and legally most relevant comment to be made on the resolution is that the embargo operates unequally between the two sides principally engaged in the conflict. The Serbians in Bosnia had (and have) the support of the Serbians in Serbia and the latter have the benefit of access to the stocks of arms of the Yugoslav National Army, the production of arms factories in Serbia and the import, in breach of the embargo, of arms and military equipment via the Danube and other routes. The Bosnian Muslims did not (and do not) have these advantages. . . . $102 . \ldots$ the inability of Bosnia-Herzegovina sufficiently strongly to fight back against the Serbs and effectively to prevent the implementation of the Serbian policy of ethnic cleansing is at least in part directly attributable to the fact that Bosnia-Herzegovina's access to weapons and equipment has been severely limited by the embargo. Viewed in this light, the Security Council resolution can be seen as having in effect called on Members of the United Nations, albeit unknowingly and assuredly unwillingly, to become in some degree supporters of the genocidal activity of the Serbs and in this manner and to that extent to act contrary to a rule of jus cogens." "Application of the Convention on the Prevention and Punishment of the Crime of Genocide," Provisional Measures, Order, September 13, 1993, ICJ Reports 1993, p. 325, pp. 438, 441.

37 On this point, see J. Saura-EStapà, "The UN Security Council Ombudsperson: An Original Institution Still Under Construction," Revista Catalana de Dret Públic, No. 54 (2017), pp. 185-195.

38 A.J. Sarna, Boycott and Blacklist: A History of Arab Economic Warfare Against Israel (1986), p. 286; N. Turck, “The Arab Boycott of Israel," Foreign Affairs, Vol. 55 (1977), pp. 472-493; Joyner, supra note 5, pp. 216-221.

39 Ibid., p. 214; Muir J. Dapray, "The Boycott in International Law," Journal of International Law and Economics, Vol. 9, No. 2 (1974), pp. 187-204, at p. 189.

40 Joyner, supra note 5, pp. 214-215. 


\section{Jean-Marc Thouvenin}

41 Rathbone, Jeydel, and Lentz, supra note 3, p. 1064.

42 Ibid., pp. 1075-1081.

43 "Military and Paramilitary Activities in and Against Nicaragua (Nicaragua v. United States of America)," Merits, Judgment, June 27, 1986, ICJ Reports 1986, p. 14.

44 Rathbone, Jeydel, and Lentz, supra note 3, p. 1065.

45 ECJ, September 3, 2008, Kadi, C-402/05 P et C-415/05. In this case, the European Court of Justice considered that since the basic right of defense had not been respected by the UN Security Council before adopting its decision to sanction Mr. Kadi, nor by the European Council, which purely and simply transposed the UN decision in the European Union's order, the sanction could not be implemented in the European Union.

46 Regulation (EEC.) $n^{\circ} 877 / 82$, and Decision 82/221/ECCS.

47 J.-L. Dewost, "La Communauté, les Dix et les 'sanctions' contre l'Argentine - De la crise iranienne à la crise des Malouines," Annuaire français de droit international, Vol. 28 (1982), pp. 215-232.

48 C. Fabre, "Secondary Economic Sanctions," Current Legal Problems, Vol. 69, No. 1 (2016), pp. 1-30.

49 For example, the European Union does not adopt such secondary sanctions.

50 For example, the economic sanctions regime decided by Arab States against Israel included secondary sanctions; the United States frequently adopts secondary sanctions to economically isolate Syria and Iran.

51 On this point, see, for example, Alleged Violations of the 1955 Treaty of Amity, Economic Relations, and Consular Rights (Islamic Republic of Iran v. United States of America), Request for the indication of provisional measures, Order of October 3, 2018, Declaration of ad hoc Judge Momtaz, paras. 15-28. 


\section{Implementation of sanctions United States}

Richard Nephew

\section{Introduction}

Since the end of the Cold War, the United States has employed dozens of sanctions in a variety of contexts in order to manage a plethora of challenges. Targets of sanctions have included terrorist groups and human rights violators, states and individuals, banks and corporations, and all manner of illicit activities. Sanctions also enjoy a somewhat unprecedented amount of bipartisan legitimacy, with many sanctions debates centering on how much pressure to apply through their use rather than whether they ought to be contemplated in the first place. As an example, even as the US Congress debated whether to support the 2015 Joint Comprehensive Plan of Action (JCPOA) reached by the United States, its negotiating partners, and Iran, the continued persistence of US sanctions against Iran was a selling point for those who favored the agreement.

It is almost inconceivable to describe a future of US foreign policy in which sanctions do not play at least some role, though there are many signs that US facility with sanctions imposition will be matched by the retaliatory and defensive capabilities of adversaries. Even the Trump Administration, which was initially run and staffed at the senior most levels by a combination of businesspeople and generals, has seen fit to employ sanctions in managing a variety of challenges, including North Korea's nuclear program and Venezuela's collapse into economic ruin and political tyranny. Yet, for all the current euphoria around sanctions, they have a mixed legacy in US history, playing a vital role in some areas and potentially an inflammatory role in others. Moreover, the limits of sanctions power are also beginning to be realized.

In this chapter I will examine the history of US sanctions; their present legal, political, and organizational structures; and their use in a variety of present and possibly future conflicts. Throughout, I will underscore three main themes:

1. Sanctions have achieved a preeminent place in US foreign policy because they appeal to US strengths and address US weaknesses.

2. The success of sanctions to date owes equally as much to the attractiveness of the United States intrinsically as to the policy goals that they serve. 


\section{Richard Nephew}

3. Prudence, care, and restraint in using sanctions will not only preserve them for future conflicts but also help to underscore the importance of issues against which they are employed.

To this last point, a caution will be registered as well: the casual use of sanctions, particularly in service of policy objectives that are unclear, unachievable, or at cross purposes with those of US partners, will ultimately limit their accessibility in future crises, raising the risk of other forms of conflict, including war.

Sanctions, after all, are not merely an instrument of foreign policy but also a means of managing problems that, left unattended, could metastasize and become far worse. If sanctions are damaged in the zeal to apply them in unnecessary or counterproductive ways, then the instrument itself can atrophy, leaving US policymakers with fewer options in the future.

\section{History of US sanctions}

Sanctions have been used by the United States since shortly after the birth of the nation. But, when first employed, they were in service to a country that had scant international political legitimacy, capacity to enforce them, or an economy that made abiding by sanctions more attractive to foreign states than persisting with whatever had caused sanctions to be imposed in the first place. Over the following 200 years, circumstances changed, with the United States becoming a country capable of levying sanctions that would stick and put at risk something of value to those against whom they were employed. After World War II, US sanctions became a significant source of leverage, primarily in managing recalcitrant partners and allies; at the end of the Cold War, they became a potential source of regime rattling power when employed properly.

\section{Pre-World War II}

Arguably, the first real use of sanctions by the US federal government occurred in 1806, with the passage of the Non-Importation Acts and subsequently the Embargo Act of 1807. Signed into law by President Thomas Jefferson, the acts were intended as a response to attacks and harassment of US merchant vessels by primarily the British navy, though the French navy was also guilty of such acts. These attacks took place in the context of the Napoleonic Wars in Europe and were defended by European governments as necessary for the prosecution of this larger conflict. The attacks not only resulted in lost business but also undermined the sovereignty and independence of the newly minted United States. For this reason, Congress - with the full support of the President, although not Secretary of the Treasury Albert Gallatin - prohibited limited types of trade with Great Britain and, in time, foreign trade altogether. ${ }^{1}$

These sanctions were a dismal failure. Notwithstanding some damage from the embargo dealt against primarily the British, ${ }^{2}$ US and European merchants alike evaded them, and the sanctions resulted in heavy economic losses in the 
Northeast. ${ }^{3}$ By the end of 1808 , the British were able to replace the 6.6 million pounds in export trade they had in 1807 with the United States, with 6.1 million pounds in export trade with non-US America, including Canada and South America. ${ }^{4}$ This resulted in a decision to reduce the scope of the embargo, focusing it instead on Great Britain and France through the Non-Intercourse Act of 1809, which was still insufficient to avoid a drift toward war with Britain. ${ }^{5}$

From 1806 to 1812, sanctions failed the "or else" test that might have proved invaluable in convincing US adversaries that they were better off cooperating than not. Fifty years later, a different United States faced the international community with a new conflict, this time a civil war that pitted North against South. During the US Civil War, the US federal government prohibited trade with the Southern states of the Confederacy, treating it as a set of rebellious provinces. Given the nature of the global economy at the time, this embargo was directed mainly at European countries, and it was more effective.

By this time, a variety of factors had changed. First, trade with the United States overall had become more important, measured both in the value of US exports and imports ${ }^{6}$ and in the particular case of one of those exports - cotton as feed for foreign industry. Countries - particularly Great Britain - were sensitive to the risks of losing access to the totality of US trade if they infringed upon the embargo as well as the threat of future punishment if the Southern secessionists lost the war. ${ }^{7}$ The ability of the United States to enforce its laws was a second major factor. Unlike in 1807, the United States was able in 1861 to present a compelling picture of enforcement to foreign parties that made them reluctant to cross swords with the US government.

Still, by the turn of the twentieth century, the United States had an ill-formed understanding of when and how to use sanctions. Thus far, it had used sanctions primarily as a means of defense for national sovereignty. Foreign policy use would come after World War I, when the international community sought ways to avoid the slaughter of that conflict in future scenarios.

Though President Woodrow Wilson brought the United States into the war, he also made a strong case for the use of sanctions to address foreign policy issues without resorting to military conflict. He was an early advocate of "a general association of nations . . . for the purpose of affording mutual guarantees of political independence and territorial integrity to great and small states alike,", and an early draft of the association agreement includes the concept that if the collective will of the association were to be ignored by any state, the consequence would be "suspension ... of all treaty privileges and of all diplomatic, commercial and economic intercourse." The final text of the Covenant of the League of Nations includes, in Article 16, language requiring the imposition of sanctions against countries that make war on another, ${ }^{10}$ and they were imposed in response to a variety of conflicts thereafter, including against Imperial Japan for its occupation of Manchuria and Italy for its occupation of Ethiopia. But in neither case was the league able to compel the targets of their sanctions to halt their activities, badly damaging the sense of efficacy of the league and the tool of sanctions. 
With Imperial Japan, sanctions may have also played a role in the eventual war to come with the United States. The United States used sanctions throughout 1940-1941 in response to Japanese occupation of greater swaths of East Asia. Starting with revocation of a commercial treaty and increased licensing but eventually proceeding to the freezing of assets and prohibition on all manner of trade (including that of oil, which was seen as an Achilles heel for the Japanese military), the United States sought to communicate to Japan that further steps on its part would lead to war. ${ }^{11}$ Scholarship since 1941 suggests that the Japanese government took the opposite lesson, deciding to expand its activities - and eventually deciding to risk war with the United States - for fear that failure to do so would leave it at the mercy of the United States. ${ }^{12}$ Either way, sanctions were unsuccessful in preventing conflict with Japan. Still, they became a component of fighting World War II regardless. In 1940, the United States had created the Office of Foreign Funds Control (FFC) at the US Department of the Treasury to prevent Nazi Germany from using the assets of those countries that it invaded, starting with Norway. ${ }^{13}$ FFC was used by the secretary of the treasury to deny the Germans and other Axis powers the ability to profit from their military conquests and thereby further fuel their military activities.

\section{During the Cold War}

FFC became the Office of Foreign Assets Control (OFAC) in December 1950, when President Harry Truman declared a national emergency with respect to China's entry into the Korean War. ${ }^{14}$ Truman used this authority to freeze the assets of China and North Korea, subject to US jurisdiction. Other US sanctions tools would also be employed against communist countries and their proxies throughout the world, including Cuba and North Vietnam.

However, throughout the Cold War, a substantial portion of the US sanctions effort was directed at managing its own network of allies, partners, and clients. To some extent, this makes sense and is a function of the bipolar global power structure that emerged. Sanctions against the Soviet Union and other such states did exist but ultimately were less effective, considering that communist presence in all corners of the world limited the utility of those sanctions. Export controls and similar measures were employed to prevent advanced technology from falling into the hands of US adversaries as well as arms and other goods. But, for other goods, there was less relevance from such sanctions.

For those inside the US-led power bloc, on the other hand, there were opportunities to use sanctions pressure. As Hufbauer, Elliott, Schott, and Oegg demonstrated in their seminal work, Economic Sanctions Reconsidered, the United States found many ways of using foreign dependence on US aid and access to US markets to its advantage. ${ }^{15}$ In some cases, these involved targeted measures intended to defuse crises (as in Latin America, Southeast Asia, and Africa throughout the 1960s and 1970s), but in other cases they were used to stop foreign policy adventures deemed inconsistent with US interests (as with the Suez Crisis in 1955, when the United States threatened and imposed sanctions against France, Israel, 
and the United Kingdom over the seizure of the Suez Canal from Egypt). ${ }^{16}$ The dominance of the US economy in the postwar world played a significant role in enabling sanctions pressure, but so did the bipolar nature of global politics. There were real risks to countries being left out of the US-led international economy and few alternatives, particularly for countries that did not wish to become part of the Soviet-led bloc or where independence was complicated or difficult.

Over time, however, even these tools began to lose some of their luster. Hufbauer et al., pointed to the erosion of US dominance of the global economy as an element of this, particularly as it relates to technological denial, as alternative sources of sensitive technology emerged in the 1980s, as well as fears from Washington that sanctions could tip potentially sensitive circumstances further into opposition with US interests. They also noted that US foreign aid patterns had begun to shift away from wholesale programs of assistance to smaller, more specific activities, such as helping countries manage disease. By the 1980s, the United States was increasingly sensitive about the role and use of sanctions, particularly in areas that appeared to be contested Cold War battlegrounds. This may explain, in part, the Reagan Administration's reluctance to support broad international efforts to apply pressure on the Apartheid government of South Africa, which it implied might open the door to the Soviet Union in Southern Africa. ${ }^{17}$

\section{After the Cold War}

With the collapse of the Soviet Union and the rise of the United States as the sole superpower, the use of sanctions by the United States increased markedly. However, the modalities for sanctions use also changed. Prior to 1990, the United States acted unilaterally most of the time. After 1990, the proportion of unilateral to multilateral cases shifted significantly in favor of increased reliance on international cooperation. ${ }^{18}$ As noted earlier, the focus of sanctions also shifted away from matters around the global contest for power and toward a variety of interests and goals. Counterterrorism, human rights, and democratization rose in importance in the foreign policy agenda and therefore influenced the selection of sanctions targets and tools.

For the most part, the United States sought to engage international partners in these efforts either by going through the UN Security Council (UNSC) or assembling coalitions of likeminded states. In these efforts, countries would agree to isolate another - or individuals or entities of concern - either through legally binding UNSC resolutions or cooperative actions. But in some cases this was not possible because of differences in view over the utility or appropriateness of imposed sanctions.

In response, and perhaps most important to the evolution of the US sanctions strategy, the United States also began to augment its sanctions activities to include those beyond direct sanctions - or "primary sanctions" - and to embrace what became known as "secondary sanctions." In US parlance, "primary sanctions" are those that deny access to the United States in some fashion to another party in response to a particular transgression. US entities and individuals are the vehicle 
of denial, and it is business with them that is targeted. "Secondary sanctions" similarly threaten access to the United States but against a foreign person for doing business with another foreign person against whom the United States has erected a sanctions regime. Put another way, the United States stopped merely penalizing US firms and foreign firms if they had an objection to the policies undertaken by the home government of those foreign firms; they now began threatening penalties against foreign firms if they engaged in business with other foreign firms if they had an objection to the policies undertaken by the home government of one of the foreign firms.

From this innovation came a variety of sanctions efforts, including those targeting Iran and Libya - most directly in the 1996 Iran-Libya Sanctions Act or ILSA - and those targeting Cuba in the 1996 Helms-Burton Act. These efforts were controversial. Even the concept of "secondary sanctions" was and is disputed, with other governments referring to such measures as "extraterritorial." European governments resented the United States' attempt to exert leverage over the business dealings of its companies. They acted in 1997 to pass blocking legislation that prohibited European companies from complying with US sanctions and permitting European governments to retaliate if need be. ${ }^{19}$ They also considered suits at the World Trade Organization (WTO) that would declare these steps to be unfair trading practices. Through diplomacy, the United States was able to work out mutually satisfactory solutions to these disputes, and over time secondary sanctions even received some credit for having enabled diplomatic solutions in conflicts like Iran. US sanctions, for example, covering Iranian sales of oil and precluding its access to oil revenues may have played a significant role in incentivizing Iran to seek a diplomatic outcome, and indeed, the JCPOA itself. ${ }^{20}$ Other secondary sanctions, particularly those dealing with terrorism, were also less controversial after the events of 9/11 and the resulting War on Terrorism. But at the heart of any reconciliation was the fact that political agreement still existed among protagonists about the end goal of the sanctions. As we shall see in Section III, this may be increasingly under duress as a baseline condition.

\section{Current legal and administrative system}

The current US sanctions system has a variety of components but rests on two legal bases: first, the ability of the US Congress to pass laws regarding foreign commerce with the United States; and second, the delegated ability of the US president to enforce specific sanctions and to announce new ones upon declaration of a national emergency with respect to a particular contingency. Acting on these bases, several regulatory and administrative authorities help to enforce the resulting federal sanctions regime. This section will examine each of these in turn, ending with a discussion of penalties and consequences for breaching sanctions.

\section{Statutory}

The ability of Congress to pass laws covering foreign commerce is set out in Article I, Section 8 of the US Constitution. In fact, it is through this fundamental set 
of authorities that Congress is able to pass laws governing a whole range of international economic behavior as well as to set the international economic agenda of the United States. It is also through this authority that the ability of individual states to regulate commerce with foreign governments is restricted, as the US Supreme Court has consistently maintained since 2000 with the case of Crosby v. National Foreign Trade Council (NFTC), which centered on the State of Massachusetts's sanctions against Myanmar. ${ }^{21}$ Though US states have the ability to impose limited restrictive measures that take a sanctions role, such as barring certain activities from being funded by state pensions or procurement activities, it is the US Federal Government that sets the overall agenda.

Over the history of the United States, Congress has passed both specific sanctions laws as well as broad framework laws that delegate authorities to the president.

With respect to the first, Congress has on many occasions directed sanctions against individuals, entities, and countries as circumstances warrant. Targets of US sanctions have included a diverse cast, including states like Iran and individuals such as those who were culpable for the death of Sergei Magnistsky, a Russian dissident murdered in 2009 in Russian prison. In these cases, Congress has defined what is permissible and what is impermissible conduct, denying trade relationships and conditioning financial aid or access to the US financial system. It is also the means through which Congress imposes sanctions most often, especially since the 1970s. Most, but not all, of this legislation has either defined expiration dates or criteria for termination, some of which are onerous, such as, in the case of Iran, a requirement that Iran no longer pose a threat to the United States or its interests. ${ }^{22}$

Congress has also established a number of sanctions authorities that either grant authority to the president or require him or her to take action in the event that certain defined conditions are met. These authorities are less case specific and more generally available to deal with particular problems that may emerge at any time. Examples of these authorities include the following:

- The International Emergency Economic Powers Act (IEEPA) permits the President to declare a national emergency with respect to a given country or issue and then to enact economic sanctions in response to it. ${ }^{23}$

- The Immigration and Nationality Act (INA) gives the President authority to refuse or nullify visas for individuals accessing the United States but deemed a security risk. ${ }^{24}$

- The Trading with the Enemy Act permits the President to declare a foreign country an enemy of the United States and then to preclude a range of economic activities with the associated government and its companies. ${ }^{25}$

- The Export Administration Act of 1979 regulates export controls and trade in a variety of goods but has also had a complicated history due to an ongoing debate over the future of US export controls. ${ }^{26}$

- The Arms Export Control Act (AECA) regulates export controls and trade in arms. $^{27}$

- The Foreign Assistance Act regulates foreign aid and assistance programs. ${ }^{28}$ 
Of these authorities, IEEPA may be the most far reaching, as it is on its basis that dozens of sanctions programs have been developed and implemented by the executive branch since the 1970s. By delegating the authority to the President to determine which situations merit the imposition of sanctions, and according to the President's far-reaching authority to determine the scope and scale of those sanctions, Congress gave the United States flexibility to make foreign policy decisions in response to changing international circumstances without the necessity of reverting to lengthy legislative debates on such issues or even the merits of sanctions imposition.

But the pendulum may yet swing back against executive discretion. In 2015, Congress passed the Iran Nuclear Agreement Review Act (INARA) ${ }^{29}$ which created conditions that the President had to satisfy in order to first bring into force the Joint Comprehensive Plan of Action (JCPOA) negotiated with Iran and, second, to keep waiving US statutory sanctions to sustain the agreement through its implementation phase. Though the administration was able to overcome opposition to the JCPOA in the summer of 2015 and proceed to implement the agreement in January 2016, this was a crucial test of the flexibility and power previously granted to presidents to apply and remove US sanctions. It has also yielded copycat legislation with respect to North Korea, which has yet to pass, and with respect to Russia, which did in 2017 with the Countering America's Adversaries Through Sanctions Act, or CAATSA. ${ }^{30}$ Among the many provisions was a general prohibition on the President removing sanctions against Russia absent a review process involving Congress that echoed exactly the terms of INARA. Defended as an attempt to rein in the possibility of an agreement being reached with two US adversaries without adequate Congressional scrutiny, this legislation sought to constrain the sanctions policy prerogatives previously assigned to the President.

\section{Executive orders}

The primary means of presidential implementation of sanctions lies in the form of executive orders (EOs). These are legal decrees that the President can make that have the force of federal law. There is no direct constitutional basis for executive orders per se, but they are broadly authorized pursuant to the President's responsibility as the chief executive of the US federal government. And, as noted with respect to IEEPA and the "national emergency" decisions, they are also occasionally authorized - or even directed - by Congress.

Under IEEPA, the President has declared national emergencies with respect to countries and activities as diverse as those targeting traffic in blood diamonds (EO 13312, effective in July 2003) and those targeting North Korea (EOs 13466, 13551, 13570, 13687, 13722, and 13810). Within EOs, the President defines the bad acts being addressed by the sanctions, sets out the authorities delegated to his officials for execution of his directives, and defines crucial terms. The President can also lay out the terms for nonimplementation of his directives, establishing exceptions to sanctions and the criteria for targeted imposition of penalties on individuals, entities, and countries. 
Actual execution of these decisions is carried out by cabinet agencies. But the process for deciding on whether and how to impose sanctions is usually run by the President's advisors within the Executive Office of the President (EOP). EOP is an umbrella organization for a variety of entities, most important of which for sanctions is the National Security Council (NSC) staff. Under the 1947 National Security Act, there is a statutorily defined group of officials who comprise the NSC. For most of its history, the NSC has included the President, Vice-President, Secretary of State, Secretary of Defense, and Secretary of Energy. Statutory advisors include the Chairman of the Joint Chiefs of Staff (JCS) and the Director of National Intelligence (DNI). ${ }^{31}$ Other officials - including the Secretaries of the Treasury and Homeland Security, Director of the Central Intelligence Agency, National Security Advisor, and Ambassador to the United Nations - have often been added to the NSC process at the discretion of the President.

The NSC staff is somewhat different, serving essentially as the keepers of the process that leads to executive decisions. They work for the President and National Security Advisor but effectively work for the interagency process that enables decisions to be made and communicated throughout the government. Organizationally, this is usually reflected in a series of regular meetings held at the White House in which representatives from the relevant agencies are convened to discuss, deliberate, and debate on policy options for the President and his key officials. It is usually through the NSC staff-run process that sanctions decisions are identified, prepared for senior official consideration, and then disseminated in the US government.

\section{Agencies}

Within the US government, there are a variety of agencies that have roles to play in the development and implementation of sanctions, each depending on their specific ambits. But there are three principal agencies that merit discussion here: the Treasury Department, the Commerce Department, and the State Department.

\section{(1) Treasury Department}

By virtue of its ownership of OFAC and subsequent responsibility for managing US embargoes, the Department of the Treasury has long served as an executor of sanctions decisions. However, only in the last 20 years has the Treasury taken on the more vibrant sanctions development and enforcement role for which it is now famous - and infamous among its international detractors. As Juan Zarate noted in his book Treasury's War, the realization in the early days after $9 / 11$ that terrorist groups and others relied on the international financial system to engage in illicit conduct led to the development of a host of new tools and approaches toward sanctions. ${ }^{32}$ This included direct intelligence gathering activities with other financial institutions beyond the international exchange of information on suspicious transactions and similar activities that had been part of the Treasury's mandate through its Financial Crimes Enforcement Network (FINCEN) office since 1990, as well as the design of new policy tools, such as EO 13224. This executive order 
made sanctionable transactions in support of terrorists, allowing bank accounts to be frozen throughout the United States and scaring foreign banks to take the same actions around the world. Today, the Treasury has hundreds of civil servants and attorneys responsible for identifying sanctionable conduct, enforcing cases, and coming up with new approaches for sanctions concepts and enforcement.

The most direct and visible manifestation of the Treasury's reach is the Specially Designated Nationals and Blocked Persons (SDN) list. The SDN list was created in order to facilitate the Treasury's primary mission of protecting the US financial system. The list advises banks and corporations as to individuals and entities that must be avoided pursuant to US sanctions programs. For this reason, every international bank includes screens against those who are on the SDN list as part of their normal compliance program. This alone would give the SDN list considerable power, as banks see it in their interest to avoid risks that could come along with doing business with US-sanctioned persons, even if not legally obliged to do so. In the case of Iran - as will be discussed later - the United States raised this normal business practice into the status of an obligation if foreign banks wish to continue doing business in the United States.

Importantly, the Treasury has also used the threat of substantial fines, the conservative natures of most banks, and the general murkiness of international banking to create a culture of self-deterrence within international banking. Some banks refuse to countenance business with a range of potentially problematic actors, even if sanctions do not presently exist, out of an overabundance of caution and risk avoidance. This culture is not legally a form of sanctions, but in the context of the centrality of the US financial system and its regulators, it can have much of the same impact on an individual business basis.

The Treasury has also used its role as one of the guardians of the integrity of the international financial system to go after those who violate its rules, in particular with respect to money laundering. Treasury authorities in this regard were substantively improved with the passage of the USA PATRIOT Act in 2001. Section 311 of the Patriot Act authorizes the Treasury to declare particular jurisdictions "primary money laundering concerns" and to require "special measures" against those jurisdictions by US financial institutions. The result is an ability, in effect, to declare jurisdictions as small as individual banks and as large as entire countries persona non grata for the US financial system. Given the outsized role of the US financial system in the broader international context, this can render those same jurisdictions toxic globally. The 2005 finding that Banco Delta Asia was such a jurisdiction was justified on the basis of its role in helping North Korea's leadership to engage in illicit finance..$^{33}$ It likely contributed to the decision of the North Korean leadership to seek negotiations with the United States over its nuclear program but may also have complicated those negotiations. ${ }^{34}$

\section{(2) Commerce Department}

The Commerce Department's role in sanctions stems primarily from its responsibility for export control enforcement. In this capacity, Commerce has the mandate 
to develop, monitor, and enforce US export control policies with respect to most though not all - goods that may be exported from the United States; other agencies, such as the Department of Energy or Department of State, have responsibilities over specific niche goods, such as nuclear technology or munitions. In this role, Commerce is often employed to manage the goods aspects of the primary US sanctions that exist. They can assign countries, entities, and individuals to lists that control the degree to which those sanctioned can access US goods of various descriptions. They also investigate reports of violations of US export controls, with a law enforcement mission and arrest powers in instances of noncompliance.

Importantly, for non-US persons, Commerce's reach goes beyond US shores. Commerce also has the responsibility to enforce US export controls with respect to reexported goods and transshipped goods. In part for this reason, Commerce officers are stationed in US embassies abroad and have investigatory remits that allow them to follow goods wherever they go internationally. US goods are defined as those that have more than $10 \%$ US content within them, meaning that a large portion of the world's trade can potentially be subject to Commerce jurisdiction. Likewise, goods that involve US-origin technology manufactured elsewhere are considered "deemed exports" that require the same licensing requirements. That said, the specific licensing burden attached to trade is relatively small, given attempts to keep the United States economically competitive. For example, in 2016 , out of $\$ 1.5$ trillion in exports, only $\$ 48.5$ billion was exported under a US government license. ${ }^{35}$

This important point highlights another: though the Commerce Department has a sanctions responsibility, it is also tasked with enabling US commercial activity worldwide. This split persona means that the department has to juggle a desire to be careful and cautious with embracing the opportunities that exist for US businesses abroad. This creative tension leads not only to frustrations at times for US exporters but also a desire on the part of all sides to work on export control reform - an ongoing project.

\section{(3) State Department}

The State Department has three distinct missions with respect to sanctions: sanctions design, sanctions enforcement, and sanctions diplomacy. At times, all three of these concepts clash with one another, particularly when involving sensitive jurisdictions or issues. As with the Treasury, the State Department is a usual player in NSC-led efforts to plan for sanctions use against a variety of targets. However, State Department officials are also balanced by those within the agency who may argue against the use of sanctions as prejudicial to potentially more important relationships or issues. Alternatively, on occasion, diplomats may seek sanctions authorities or use that is at variance with what is legally permissible or advantageous for US domestic economic interests.

At various times, organizations have been created within the State Department to coordinate policy positions and interests. Under Secretary of State Hillary Clinton, the State Department set up a Coordinator for Sanctions Policy office in 2013 
that, for four years, helped to deconflict the various areas of dispute within the State Department concerning sanctions. ${ }^{36}$ It was scrapped as part of then-Secretary Rex Tillerson's reform efforts in late 2017. ${ }^{37}$ Still, in the absence of another element to organize sanctions policy, it should be anticipated that new structures may be created to serve the same function in the future.

Also included in the State Department is the responsibility of managing the US interactions with international organizations that may develop sanctions such as the United Nations Security Council. Depending on the administration in question, such authority may be delegated to the US Mission to the United Nations, as was the case under Ambassador Susan Rice during the start of the Obama Administration; or it may be controlled from Washington, as was the case under Ambassador John Bolton during the George W. Bush Administration. Regardless, the responsibility still lies within the remit of State Department officers to develop sanctions resolutions and to negotiate them with foreign partners, usually with content suggestions and negotiating assistance from other aspects of the US government. One exception to the State Department's primacy in dealing with international organizations with a sanctions role is the Financial Action Task Force (FATF), which the Treasury manages as part of its more general responsibility for stewardship over the international financial system. It is through FATF that guidance for banks - not quite having the same significance as sanctions per se but serving a similar role in giving "rules for the road" - is promulgated.

\section{Penalties and consequences}

There are a variety of penalties and consequences for breaching US sanctions, some of which shift depending on the targets involved. Therefore, this section will not present an exhaustive set of penalties but rather offer an overview for how sanctions breaches are typically managed.

At the outset, it is necessary to recall the distinction in US sanctions policy between "primary sanctions" and "secondary sanctions." "Primary sanctions" involving US persons are usually treated as civil or criminal matters in which fines and prison sentences are not only possible but frequently meted out. Secondary sanctions, on the other hand, deal with foreign persons and consequently have a different set of responses.

With respect to "primary sanctions," as noted, the United States can seek to resolve those cases either through civil and/or criminal proceedings. In civil cases, the US government can assess fines and impose requirements on US persons identified as having breached US sanctions. The agency responsible for undertaking this process is usually OFAC, as it is responsible for most of the US sanctions regime, but Commerce is also responsible for investigating violations for those items under its supervision. As the State Department has noted:

Criminal and civil penalties for export control violations can be severe. For munitions export control violations, the statute authorizes a maximum 
criminal penalty of $\$ 1$ million per violation and, for an individual person, up to 10 years imprisonment. In addition, munitions violations can result in the imposition of a maximum civil fine of $\$ 500,000$ per violation of the [International Traffic in Arms Regulations], as well as debarment from exporting defense articles or services. For dual-use export control violations, criminal penalties can reach a maximum of $\$ 500,000$ per violation and, for an individual person, up to 10 years imprisonment. Dual-use violations can also be subject to civil fines up to $\$ 12,000$ per violation, as well as denial of export privileges. It should be noted that in many enforcement cases, both criminal and civil penalties are imposed. ${ }^{38}$

The Treasury, which has published guidelines for its enforcement of sanctions, also reports on a monthly basis its civil penalties data. In 2017, the Treasury assessed penalties of over $\$ 119$ million in a total of 16 cases. ${ }^{39}$ In many of those cases, the Treasury also established conditions on those penalized, including the risk of much steeper penalties for future violations. ${ }^{40}$

Importantly, though "primary sanctions" target US persons - the definition of a "US person" can include foreigners if they are acting as a US person at the time of their actions. For example, a foreign citizen who is in the United States at the time of a violation of US sanctions is considered to be a "US person" for purposes of sanctions enforcement, just as a foreign bank could be considered a "US person" if it processes payments using the US financial system. The infamous case of BNP Paribas is an important example of this. Though it is a bank registered and organized in France, it conducted hundreds of illegal transactions using the US financial system. For this reason, it was assessed massive fines - approximately $\$ 9$ billion $^{41}$ and subject to various conditions governing its future business conduct in the United States. $^{42}$

That said, it should be acknowledged that the authority of sanctions enforcers to act is not unabridged. Beyond the limitations established in law, there are also usually negotiations between those being assessed penalties and enforcement officials. These help all parties avoid costly, time-consuming litigation and instead to settle upon fair resolutions of the problems at hand. The BNP Paribas decision is one such example; it was a settlement of BNP Paribas's case at OFAC rather than a unilateral decision. Absent a settlement, the process, costs, and fines associated with that case could have been substantially higher. Still, it is an option that some assessed penalties choose to pursue, as ExxonMobil is presently doing with respect to a $\$ 2$ million fine assessed for transactions with Russia. ${ }^{43}$

With respect to "secondary sanctions," a different legal construct is used: exclusion from the United States in a variety of forms. This can include being barred from using the US financial system, as the 2010 Comprehensive Iran Sanctions, Accountability, and Divestment Act (CISADA) threatens banks that do business with designated Iranian financial institutions, and being barred from a range of normal commercial transactions, such as exports and imports. A specific list of potential penalties was first outlined in the 1996 Iran-Libya Sanctions Act, but that list has been augmented and applied in other contexts subsequently. It 
includes items such as a denial of export privileges, export-import financing, US government procurement, and denial of visas to corporate executives. And last but not least, asset freezes have also become a standard part of US sanctions imposition. These lock up the assets of sanctions targets, not usually for seizure but rather to be kept in stasis until such time as they can be released back to their target or designated beneficiaries.

\section{Implementation of UN and non-UN (autonomous) sanctions}

As outlined earlier, the US sanctions system is very complex, requiring the involvement of myriad actors, each of whom have a complex mix of incentives and interests, some of which push in opposite directions. This has shaped both the general process of sanctions implementation as well as US responses to specific requirements. The following sections will examine each in turn, using a few significant cases.

\section{General enforcement}

The previous sections outlined the constitutional and administrative structures responsible for US sanctions policy and implementation. But they do not capture some of the enforcement dynamics that are worth examining separately.

First, the United States does support UN sanctions and believes that they often act as force multipliers for US measures and US policy positions. For this reason, in many cases, the United States often goes to the UN before undertaking a major expansion of autonomous sanctions. US representatives of both major political parties and across the policy spectrum recognize that the UN Charter affords tremendous latitude to the UN Security Council to mete out solutions to various security problems, and this can redound to the US benefit. However, the level of US commitment to the UN track often falters when the realities of the multilateral process become evident. Here, the relative initial commitment to multilateralism can become a determinant of the resolve of the United States to continue with the UN process and in the efficacy of the process itself. But even administrations that enter office convinced that the UN is relatively meaningless in the current international environment often find a use for it. The George W. Bush and Trump Administrations are cases in point, as both have sought to employ the UN in confronting the challenges of North Korea, Venezuela, and Iran, even as they argue the UN is losing its relevance.

Second, with respect to UN sanctions, it is crucial to note that the US Constitution does not permit the implementation of superseding international obligations unless ratified by the US Senate, as treaties are. For this reason, decisions adopted by the United Nations are not automatically accepted as US legal requirements. Rather, they require additional legislative or executive action. For some actions, this is straightforward: under IEEPA, the President can declare a national emergency with respect to a specific matter and then require designations of individuals or entities subject to a UN Security Council (UNSC) resolution. Likewise, 
under delegated authorities for immigration, the State Department can work with other agencies, like the Department of Homeland Security, to prohibit granting visas to those on UNSC travel bans.

Theoretically, however, there are situations that could require - or be better managed by - congressional legislation. For example, consider the sanctions against North Korea that require reductions in export of oil and other commodities. The United States has no such trade with North Korea; therefore its exposure to UNSC sanctions and mandates is marginal. But if there were such trade, though the President may be able to implement such a mandate through an executive order, it would be complicated and intensely political to do so, particularly if there were a variety of US companies involved in such trade, all vying for a share of the quota. In such instances, the President could elect, or feel compelled politically to seek, congressional legislation to enable the implementation of such a mandate.

This takes us to a third general point: the involvement of lobbying activity in the United States. Possessing a large, vibrant, and diverse civil society, there are almost no issues in the United States that do not have an interest group attached to a particular outcome. These range from environmental groups to business interest groups to country-specific advocates, but they share an ability to influence the legislative and administrative process. Some of this is formal, such as through the Federal Register Process, in which new administrative rules are subject to public inquiry and scrutiny, including some sanctions decisions. Other aspects of this process are informal, with copies of legislation or sanctions proposals being floated by one party or another with members of Congress or parts of the executive branch. These groups can help insulate or expose particular countries, individuals, or entities from sanctions, and they influence the scope and scale of sanctions decisions in myriad ways.

The 2017 experience with the Russia sanctions in CAATSA is a case in point. Though treated until the summer of 2017 as unlikely to pass, Senator Ben Cardin's drive to include Russia sanctions in a bill being put forward on Iran sanctions resulted in a draft containing both being passed by the Senate and sent to the House of Representatives. This was the starting pistol for a range of negotiations. Some wanted to see the energy sanctions against Russia increased, while others wanted to ensure fair and equal treatment for US companies and their European competitors, and still others - including the President - wanted the sanctions gone altogether. The result was a bill that reduced the intensity of some aspects of the Russia sanctions, inclusion of new North Korea sanctions in the bill, and strong bipartisan support for the resulting package. Throughout it all, those lobbying Congress - foreign governments, energy companies, civil society advocates - presented a variety of views that were accommodated to varying degrees in the final text.

\section{Cuba}

Lobbying activity is a useful point of departure in which to consider sanctions on Cuba. During the height of the Cold War and responding to a massive 
nationalization of US assets after the Cuban Revolution, the United States under President Dwight Eisenhower reduced trade with the island and eventually imposed a comprehensive export embargo. In 1958, the year prior to the Cuban Revolution, Cuban exports to the United States accounted for \$500 million in Cuban national revenue, much of this coming from sugar. ${ }^{44}$ But in 1960, President Eisenhower cut the quota of Cuban sugar imports by 700,000 tons, from $3,119,655$ tons,${ }^{45}$ becoming a full embargo two years later under President John F. Kennedy.

Under normal circumstances, many could have expected the US embargo to sound the death knell of the Cuban economy. But the Cold War dynamics of USSoviet competition soon ensured that Fidel Castro's government would bear a substantially reduced cost for his break with the United States. The Soviets stepped in quickly to make up the lost US market for Cuba. Whereas in 1958 Cuba exported only $2 \%$ of its total exports to countries in the Sino-Soviet bloc, this dramatically increased to over $70 \%$ in $1961 .{ }^{46}$ Consequently, Cuba experienced growth from the end of the revolutionary period through the early 1990s, with the notable exception of the economic crisis in 1979 that led to the Mariel Boatlift episode in 1980.

With the collapse of the Soviet Union, Cuba temporarily lost its economic lifeline, rediscovering it in the form of subsidized fuel prices from Hugo Chavez's new government in Venezuela. But, notwithstanding the significant changes in global affairs, the embargo remained in place against Cuba. In 1996, it was even strengthened in the form of the Helms-Burton Act, which sought to impede international business in Cuba by permitting sanctions, including visa denial, for those companies and individuals that traffic in "confiscated property." But, following a diplomatic brouhaha prompted by the concerns of US trading partners who saw this legislation as extraterritorial, ${ }^{47}$ Helms-Burton was largely left aside and ignored by the Clinton and George W. Bush Administrations.

Cuba's relationship with Venezuela could not make up for the more systemic failures of the communist system. In 2008, Raul Castro succeeded his brother as the President of Cuba and began to introduce market and political reforms. Six years later, the United States and Cuba announced that they were moving toward political reconciliation, involving further reforms in Havana and sanctions relief in the United States.

Still, though $65 \%$ of Americans support the idea of opening up relations with $\mathrm{Cuba},{ }^{48}$ there remains a significant minority of legislators and citizens who oppose such changes, given persistent human rights violations in Cuba. They have been able to stymie further discussions. The embargo against Cuba remains fully in place regardless of its weak efficacy and opposition to it both domestically and abroad. They have even argued in favor of continuing the embargo and curtailed relations. Senator Marco Rubio, for example, stated in 2015 that "We owe the Cuban people more time so we can get it right." 49 Given that the embargo has been codified into US law via statute, this powerful minority of Americans has succeeded thus far in maintaining the embargo, even as it has been trimmed and reduced. In early 2019, the Trump Administration began to make noise that it would look to reimpose some of the sanctions previously relaxed. On April 17, 
National Security Advisor John Bolton announced the tightening of the embargo and decision to permit the most controversial provision of the Helms-Burton Act - lawsuits by US citizens against those trading in "confiscated property" - to reenter into force. Sanctions efforts against Venezuela have also pointed to an intensified emphasis on Cuba, showing the degree to which hostility with Cuba (and, as a result, sanctions) remains a potent feature of US foreign policy thinking in some circles.

\section{Iraq}

In a move that is perhaps ironic, considering the Cuban embargo, the decision to invade Iraq in 2003 was in part on the basis of a conviction that the sanctions against Iraq were failing to prevent foreign business activity in the country, Saddam Hussein was neither closer to being toppled nor cooperating fully with international inspectors of his military, and the military had developed weapons of mass destruction (WMD). Prior to that point in time, however, there was widespread support for vigorous implementation of the Iraq sanctions. These had been adopted by the UNSC in 1990 in response to Hussein's invasion of Kuwait. After the Iraqis were evicted from their southern neighbor in 1991, the sanctions remained in place as a check against future Iraqi militancy and - it was hoped to undermine the stability of the Iraqi government. However, by the end of the 1990s, Hussein remained ensconced in his palaces.

As noted in my book, The Art of Sanctions, the sanctions against Iraq had largely succeeded in preventing the reconstitution of Iraq's conventional military and unconventional military projects. ${ }^{50}$ But they had also helped to generate a significant humanitarian crisis in Iraq. In no small part this was because of the total nature of the sanctions the regime imposed. All manner of items, even those without significance to Iraq's military, were subject to scrutiny and rejection. Even efforts intended to bring hard currency back into the country for the purpose of humanitarian relief, including the now discredited Oil-for-Food Program, were unable to address the fundamental problems inherent in the sanctions.

Sanctions suffered a double blow in this moment, being seen as both ineffective and cruel. Delegitimized within the United States - with few exceptions like Cuba - they fell out of favor in the late 1990s and early 2000s.

\section{Iran and North Korea}

In the cases of Iran and North Korea, sanctions returned to a position of prominence in US thinking in the early 2000s. With respect to both countries, some degree of reluctance was involved in their resurrection. From my experience at the State Department starting in 2006, I can attest that US leaders were deeply skeptical that sanctions would bring much value. However, they were resorted to in no small part due to a lack of other options.

In the case of Iran, the invasion of Iraq and more difficult occupation sapped enthusiasm for military options to deal with its nascent nuclear program. ${ }^{51}$ 
Moreover, international support for any kind of coercive diplomacy with respect to Iran was simply lacking. International partners, particularly in Europe, were convinced that a diplomatic solution could be engineered and set about seeking a suspension of Iranian nuclear activities. After three years of attempts, they concluded in 2005 that Iran's leadership required additional pressure to convince them to pursue diplomacy. European partners joined the United States, and after an offer of long-term diplomatic settlement was conveyed to Iran, so did the Russians and Chinese in pursuing UNSC sanctions against Iran.

But these sanctions were largely limited to prohibiting specific technical assistance to Iran's nuclear and missile programs. They were hardly enough to change Iran's strategic calculus with respect to the wisdom of these programs; rather, these measures just made achieving success in them more difficult. For this reason, the United States sought to apply pressure against Iran's economy using its own economy as leverage. As noted previously, the United States began to threaten access to the US financial system to compel banks to withdraw their business activities from Iranian banks accused of facilitating proliferation or terrorism. This campaign grew to include insurance companies, shipping companies, industry, and all manner of service providers. The result was that Iran was increasingly isolated from the international economy when the United States began to apply sanctions against its oil sales and the revenues accumulated from those sales. Though some debate the degree to which sanctions were instrumental in convincing Iran to enter into negotiations, preferring to see the offer of a negotiated outcome that accepted Iran's uranium enrichment program as essential, ${ }^{52}$ the sanctions regime demonstrated the degree to which the United States had understood new global realities with respect to the latent power of its economy and the threat of its denial. Moreover, the sanctions regime and subsequent negotiation also demonstrated a realistic approach toward the kinds of diplomatic outcomes that sanctions can best achieve - not regime change, perhaps, but regime policy change.

This vantage point has been put to the test by the decision by Donald Trump to reimpose US sanctions against Iran and withdraw from the JCPOA in May 2018. Sanctions were again implemented in August and November 2018, with administration officials increasingly speaking about the need for fundamental changes in Iranian policy as a necessary element of future sanctions relief. Though as of this writing it is too soon to say whether these efforts will be successful, the degree to which the attempt has isolated the United States from its close partners - many of which still support the JCPOA - will put to the test the degree to which US unilateral sanctions can be effective.

With respect to North Korea, until 2016, the effort to apply sanctions against the North Koreans was far more rudimentary. Protected to some degree by their ability to put Seoul at risk through thousands of conventional artillery pieces, the North Koreans also represented a problem that lacked a military solution. Consequently, a combination of diplomacy and sanctions has predominated. Though some sanctions pressure was applied during the Bush Administration and throughout the Obama Administration, with short-lived agreements cropping up that included some verification and dismantling of North Korean infrastructure, the 
North Koreans maintained their nuclear weapons and missile programs throughout the intervening decade.

Starting at the end of the Obama Administration and continuing into the Trump Administration, the United States has sought to galvanize international sanctions pressure against North Korea. This effort has been broadly successful, particularly as relates to the UNSC. Five UNSC resolutions have been adopted against North Korea, imposing sanctions since the start of 2016, more than those adopted in the previous decade. ${ }^{53}$

But enforcement continues to represent a real challenge, not least because of the aggressive evasion mechanisms adopted by the North Koreans. ${ }^{54}$ Moreover, serious questions remain as to the intent of the sanctions regime. US officials have speculated that North Korea cannot be deterred, and that negotiations with the North Koreans on anything other than full denuclearization are insufficient checks on the country. ${ }^{55}$ This success in applying sanctions, therefore, may not carry over to a successful diplomatic resolution. Still, in 2018, the Trump Administration decided to attempt this course, beginning with a leader-level summit in Singapore and then a second meeting in Hanoi in 2019. These talks have yet to result in any agreements.

\section{Russia}

No such unlimited objectives are present in the case of Russia, notwithstanding fears from Vladimir Putin about future revolutions in Eastern Europe. ${ }^{56}$ The United States has been clear to limit its objectives, first starting with limited sanctions in the face of Russian activities in Ukraine in 2013, and continuing through 2014's escalating sanctions framework. The sanctions adopted throughout 2014 were aimed at deterring Russia from proceeding to further undermine the Ukrainian government and others in Eastern Europe and to persuade Russia to return sovereignty over Crimea to Ukraine. ${ }^{57}$ These sanctions increasingly used economic leverage - Russian debt held by foreign banks and reliance on the oil and gas sector - but were still limited in their ambition. Even sanctions subsequently adopted by the United States in 2017 - in the aforementioned CAATSA - have focused on keeping up sanctions pressure in the face of moderating European will to confront the Russians and fears that Donald Trump would end US sanctions without Russian concessions.

This may change if indications of Russian interference in electoral processes in the United States and Europe continue. The US Congress has legislation before it dubbed the Defending Elections from Threats by Establishing Redlines (DETER) Act (now in its second version) ${ }^{58}$ - that would require a massive expansion of US sanctions against Russia and those doing business with it if future proof is uncovered about Russian interference. Moreover, many in the US Congress are considering a significant upgrade in US sanctions in response to the frozen conflict in Ukraine, ongoing war in Syria, and broader deterioration of US-Russian relations. Here, US strengths - leadership of the international economy, centrality as a market, and readiness to weaponize its economy - may play significant roles. 


\section{Richard Nephew}

\section{Conclusion}

The evolution in US sanctions policy tracks with the evolution in US strengths and responsibilities over the course of its history. At times, the United States has sought to employ sanctions well beyond their efficacy, starting with the Embargo Act of 1807, and continuing through the Cuban embargo, but at other times the United States has been successful in using its power to its diplomatic advantage. And throughout its history, the United States has been motivated to use sanctions where military tools were either unwise or unavailable.

Looking to the future, it is likely that sanctions will remain a fixture of US foreign policy. There has been a substantial investment in the mechanisms of sanctions, and from a policy perspective, they are seen as providing real value and options to presidents and congressional representatives alike. The main challenge to sanctions in the future lies in their overuse, particularly where strategic considerations ought to prompt evaluation of other tools and in the multi-polarization of the global economy. After all, much of the story of success in US sanctions policy emerged after World War II during a period in which the US economy reigned supreme. In a different global environment, US sanctions policy will need to become more agile, more adaptive, and more nimble in order to remain not only a tool of interest but also a tool of value. ${ }^{59}$

\section{Notes}

1 J.J. McCusker, History of World Trade Since 1450, Vol. 2 (2006), pp. 850-852.

2 Louis Martin Sears, Jefferson and the Embargo (2015), pp. 279-280.

3 J.S. Olson and A.O. Mendoza, American Economic History: A Dictionary and Chronology (2015), available at $<\mathrm{http} / /$ ezproxy.cul.columbia.edu/login?qurl $=\mathrm{https} \% 3 \mathrm{~A} \%$ $2 \mathrm{~F} \% 2 \mathrm{~F}$ search.credoreference.com $\% 2 \mathrm{Fcontent} \% 2 \mathrm{Fentry} \% 2 \mathrm{Fgreenwoodlgr} \% 2 \mathrm{Femba}$ rgo_act_of_1807\%2F0\%3FinstitutionId\%3D1878>.

4 Ibid.

5 Ibid.

6 US Census Bureau, Bicentennial Edition: Historical Statistics of the United States, Colonial Times to 1970 (1977), available at <https://www2.census.gov/library/ publications/1975/compendia/hist_stats_colonial-1970/hist_stats_colonial-1970p2chU.pdf>.

7 Kori Schake, Safe Passage: The Transition from British to American Hegemony (2017), p. 89.

8 President Woodrow Wilson's Fourteen Points (1918), available at $<\mathrm{http}: / /$ avalon.law. yale.edu/20th_century/wilson14.asp>.

9 US Department of State, Tentative Draft of an Agreement for an Association of Nations (1919), available at $<$ https://history.state.gov/historicaldocuments/frus1919Parisv01/ d383>.

10 The Covenant of the League of Nations (1924), available at $<\mathrm{http}$ //avalon.law.yale. edu/20th century/leagcov.asp\#art16>.

11 Jeffrey Record, Japan's Decision for War in 1941: Some Enduring Lessons (2009), available at $<\mathrm{http}: / /$ ssi.armywarcollege.edu/pdffiles/pub905.pdf $>$.

12 Ibid.

13 US Department of Treasury, "Frequently Asked Questions," available at <www.treasury. gov/resource-center/faqs/Sanctions/Pages/faq_general.aspx>. 
14 Ibid.

15 De Gary C. Hufbauer, Jeffrey J. Schott, Kimberly Ann Elliott, and Barbara Oegg, Economic Sanctions Reconsidered, 3rd ed. (2007).

16 Diane B. Kunz, The Economic Diplomacy of the Suez Crisis (1991).

17 David Hoffman, "Reagan Vetoes Sanctions Against South Africa," Washington Post (September 27, 1986), available at <www.washingtonpost.com/archive/ politics/1986/09/27/reagan-vetoes-sanctions-against-south-africa/af009ab1-2ed24e72-ab46-52fc2ec2d7e6/?utm term=.f4e27548db7b>.

18 Hufbauer et al., supra note 15, Âppendix 1A.

19 Richard Nephew and David Mortlock, "Decertification of the JCPOA and the Risk of European Union 'Blocking Regulations'," Center on Global Energy Policy (October 31, 2017), available at <http://energypolicy.columbia.edu/research/commentary/ decertification-jcpoa-and-risk-european-union-blocking-regulations $>$.

20 Richard Nephew, The Art of Sanctions: A View from the Field (2018).

21 Crosby v. NFTC, 181 F.3d 38, 530 (US 363. 2000).

22 Iran Sanctions Act of 1996, available at <www.treasury.gov/resource-center/sanctions/ Programs/Documents/isa_1996.pdf>.

23 Title 50, US Code, "Chapter 35," available at <www.law.cornell.edu/uscode/text/50/ chapter-35>.

24 Title 8, US Code, "Chapter 12," available at <www.law.cornell.edu/uscode/text/8/ chapter-12>.

25 Title 50, US Code, “Appendix, Chapter 106,40 STAT. 411," available at <www.gpo.gov/ fdsys/granule/USCODE-2011-title50/USCODE-2011-title50-app-tradingwi-other>.

26 Ian Fergusson, "The Export Administration Act: Evolution, Provisions and Debate," Congressional Research Service (July 15, 2009), available at $<\mathrm{https} / /$ fas.org/sgp/crs/ secrecy/RL31832.pdf>.

27 Title 22, US Code, "Chapter 39," available at <www.law.cornell.edu/uscode/text/22/ chapter-39>.

28 Ibid., Chapter 32.

29 Public Law 114-17, available at <www.congress.gov/bill/114th-congress/house-bill/ $1191 /$ text>.

30 Public Law 115-44, available at <www.congress.gov/bill/115th-congress/house-bill/ $3364 /$ text $>$.

31 Richard A. Best Jr., "The National Security Council: An Organization Assessment," Congressional Research Service (December 28, 2011), available at $<\mathrm{https}$ ://fas.org/ $\mathrm{sgp} / \mathrm{crs} / \mathrm{natsec} / \mathrm{RL} 30840 . \mathrm{pdf}>$.

32 Juan C. Zarate, Treasury's War: The Unleashing of a New Era of Financial Warfare (2013).

33 David Lague and Donald Greenlees, "Squeeze on Banco Delta Asia Hit North Korea Where It Hurt," International Herald Tribune (January 18, 2007), available at <www. nytimes.com/2007/01/18/world/asia/18iht-north.4255039.html>.

34 Zarate, supra note 32.

35 US Department of Commerce, Statistical Analysis of US Trade With the World (2016), available at $<$ www.bis.doc.gov/index.php/documents/technology-evaluation/ote-dataportal/country-analysis/2072-2016-statistical-analysis-of-u-s-trade-with-the-worldpdf/file $>$.

36 US Department of State, "2010 Quadrennial Diplomacy and Development Review," available at $<$ www.state.gov/documents/organization/153108.pdf> .

37 Robbie Gramer and Dan de Luce, "State Department Scraps Sanctions Office," Foreign Policy (October 26, 2017), available at <http://foreignpolicy.com/2017/10/26/ state-department-scraps-sanctions-office/>.

38 US Department of State, "Overview of US Export Control System," available at $<$ www.state.gov/strategictrade/overview/>. 


\section{Richard Nephew}

39 US Department of Treasury, "Civil Penalties and Enforcement Information," available $a t<$ www.treasury.gov/resource-center/sanctions/CivPen/Pages/civpen-index2.aspx $>$.

40 US Federal Register Notice, Vol. 74, No. 215 (November 9, 2009), available at $<$ www. treasury.gov/resource-center/sanctions/Documents/fr74_57593.pdf > .

41 Ben Protess and Jessica Silver-Greenberg, "BNP Paribas Admits Guilt and Agrees to Pay \$8.9 Billion Fine to US," New York Times (June 30, 2014), available at $<$ https:// dealbook.nytimes.com/2014/06/30/bnp-paribas-pleads-guilty-in-sanctions-case/>.

42 "Settlement Agreement Between OFAC and BNP Paribas, COMPL-2013-193659," (June 30, 2014), available at <www.treasury.gov/resource-center/sanctions/CivPen/ Documents/20140630_bnp_settlement.pdf $>$.

43 Yeganeh Torbati and Ernest Scheyder, "Exxon Sues US Over Fine Levied for Russia Deal Under Tillerson," Reuters (July 20, 2017), available at <www.reuters. com/article/us-exxon-mobil-usa-ukraine/exxon-sues-u-s-over-fine-levied-for-russiadeal-under-tillerson-idUSKBN1A51UH>.

44 William A. Messina Jr., Richard N. Brown, James E. Ross, and Jose Alvarez, "Cuban Non-sugarcane Agricultural Trade Patterns: Historical Perspectives and Future Prospects," ASCE (1997), available at <www.ascecuba.org/c/wp-content/uploads/2014/09/ v07-messina.pdf>.

45 Robert Young, "Ike Slashes Cuban Sugar Subsidies," Chicago Tribune (July 7, 1960), available at <http://archives.chicagotribune.com/1960/07/07/page/33/article/ ike-slashes-cuban-sugar-quota $>$.

46 Ibid.

47 Mark Groombridge, "Missing the Target: The Failure of the Helms-Burton Act," CATO Institute (June 5, 2001), available at $<\mathrm{http}$ ://object.cato.org/sites/cato.org/files/ pubs/pdf/tbp-012.pdf>.

48 Anthony Man, "With Trump About to Set Cuba Policy, Poll Shows Voters Like Obama's Liberalization of US Policy Toward Cuba," Sun Sentinel (June 12, 2017), available at $<$ www.sun-sentinel.com/news/politics/fl-reg-cuba-poll-trump-20170612-story. html $>$.

49 Marco Rubio, “Obama's Faustian Bargain With Cuba,” New York Times (July 8, 2015), available at <www.nytimes.com/2015/07/08/opinion/marco-rubio-obamas-faustianbargain-with-cuba.html>.

50 Nephew, supra note 20.

51 Ibid.

52 Trita Parsi, Losing an Enemy (2017).

53 Eleanor Albert, "What to Know About the Sanctions on North Korea," Council on Foreign Relations (January 3, 2018), available at <www.cfr.org/backgrounder/ what-know-about-sanctions-north-korea>.

54 Andrea Berger and Shea Cotton, "Walls and Ladders: The Latest UN Panel of Experts Report on North Korea Sanctions," War on the Rocks (March 28, 2018), available at <https://warontherocks.com/2018/03/walls-and-ladders-the-latest-un-panelof-experts-report-on-north-korea-sanctions/>.

55 Uri Friedman, "The World According to H. R. McMaster," Atlantic (January 9, 2018), available at $<$ www.theatlantic.com/international/archive/2018/01/hr-mcmaster-trumpnorth-korea/549341/>.

56 Marvin Kalb, "What Does Vladimir Putin Fear? His Own People," Time (November 28, 2017), available at $<$ http://time.com/5039688/vladimir-putin-fears-own-people/>.

57 Richard Nephew, "Issue Brief: Revisiting Oil Sanctions on Russia," Center on Global Energy Policy (July 2015), available at <http://energypolicy.columbia.edu/sites/ default/files/Issue\%20Brief_Revisiting\%200il\%20Sanctions\%20on\%20Russia Nephew_July\%202015.pdf>. 
58 DETER Act Draft (January 16, 2018), available at <www.rubio.senate.gov/ public/_cache/files/1467ea7c-ca91-45a6-be41-f5043d4bce88/BCFC8F63C1D8049CF5593DEB32703C2C.hen18060revised.pdf>.

59 Jacob J. Lew and Richard Nephew, "The Use and Misuse of Economic Statecraft," Foreign Affairs (November/December 2018), available at $<$ https://www.foreignaffairs. com/articles/world/2018-10-15/use-and-misuse-economic-statecraft $>$. 


\title{
7 Implementation of sanctions European Union
}

\author{
Francesco Giumelli
}

\section{Introduction}

The European Union (EU) is among the actors that most frequently adopts sanctions in its foreign policy. Restrictive measures, as sanctions are known in EU jargon, were used to deal with very diverse crises - from human rights promotion to conflict management - and in very different geographical locations - from the Middle East to Asian and African countries. Being the largest economic block in the world makes the EU also very central when it comes to understanding how sanctions work in the twenty-first century. At the same time, understanding the functioning of the EU when using sanctions is not an easy task due to the EU's unique institutional settings and the continuous evolution of the instrument of targeted sanctions.

This chapter aims to present the case of the restrictive measure policy of the EU. The aim of the chapter is not only to discuss the historical evolution of sanctions in the context of European integration, but it also intends to do so by focusing on the legal framework, the decision making, and the role of each actor involved. There are five main themes that the chapter highlights. First, the political integration of the European Union led to a more intensive reliance on sanctions after the entry into force of the Maastricht Treaty and the terrorist attacks of 9/11. Second, restrictive measures appear as the one-fits-all solution as they are used for very diverse foreign policy challenges. Third, the institutional setting of the EU produced a very unique (and rather convoluted) process to decide and administer restrictive measures, which involves the Council, the Commission, the EEAS, and the Member States. Fourth, the implementation and the enforcement of EU sanctions are extremely difficult to discern since they depend mainly on Member State actions, and there is little known so far in that area. Fifth, the EU often acts in coordination with the US to go beyond the mandate of the United Nations when it comes to using sanctions in its external relations. These five conclusions are reached by looking at the experience of the EU in the past two decades and, especially, by reviewing the cases of Iran, North Korea, and Russia.

The chapter is structured in five sections. The first section reviews the history of EU sanctions. The second section presents the institutional and legal framework of the sanctions cycle. The third one includes the focus on the implementation 
and the enforcement of sanctions at the Member State level. The fourth section presents the case studies of Iran, Russia, and North Korea. Finally, the conclusion summarizes the main themes of this chapter, and it indicates a number of suggestions to enhance EU sanctions in the future.

\section{History of EU sanctions}

\section{The Cold War}

Joakim Kreutz suggests the beginning of an autonomous will in the area of sanctions with the "London Report" prepared by the European Political Co-operation (EPC) in October 1981, ${ }^{1}$ but alternative narratives can also be suggested. For instance, the European Union began to impose sanctions on third parties that Member States were obliged to implement with the entry into force of the Maastricht Treaty in 1993, but foreign policy coordination had already started years before with the Treaty of Rome in 1957.

The Treaty establishing the European Economic Community (hereinafter the EEC or the Treaty of Rome) talked about sanctions in relation to arms trade and UN decisions. Article 223 indicated that Member States could act in derogation to the treaty for matters of "security which are connected with the production of or trade in arms, munitions and war material."2 Article 224 suggested that derogations to the functioning of the common market were possible to fight threats to international peace and security. ${ }^{3}$ According to Kreutz, UN sanctions on Southern Rhodesia were transposed with a joint ECC decision, ${ }^{4}$ but other sources show that national implementation was either loose or nonexistent. ${ }^{5}$

The achievement of the customs union, the necessary coordination for development aid provided under the framework of the Yaoundé Convention but also and foremost the several international crises that required a common response led to the creation of an informal mechanism for foreign policy coordination: the European Policy Co-ordination (EPC) in 1970. The EPC constituted the natural forum where to talk about EEC sanctions. Not surprisingly, EEC sanctions turned out to be a divisive issue among Member States with the cases of South Africa (1977), Libya (1978), and Iran (1979). ${ }^{6}$

The inability to play an important role by the EEC in these crises led to the "London Report" in October 1981. Thanks to an initiative of the UK, the "London Report" stressed the importance of a joint and more decisive action to address emerging crises. Joint initiatives to impose sanctions were, then, undertaken against the Soviet Union in 1981, and Argentina in 1982. The most visible legacy, which is still in force today, of the "London Report" is the arms embargo imposed on China after the massacre of Tiananmen Square in 1989. ${ }^{7}$ In the meantime, the Single European Act (SEA) had integrated the EPC into the EEC structure as indicated in Title III - Article 30 of the treaty. The Commission was given an important role for coordinating the Member States or, as defined in the SEA, the "high contracting parties." However, sanctions imposed were not legally binding for Member States because the SEA only wished for states to approximate their 


\section{Francesco Giumelli}

foreign policy to joint decisions, but it did not demand compliance. The Treaty of Rome and the Single European Act were mainly about the creation of a common market and not about foreign policy. With the creation of the European Union and the "second pillar" of the Maastricht Treaty, namely the Common Foreign and Security Policy (CFSP), EU Member States agreed to share the decision-making power on sanctions, and decisions made in Brussels would then become legally binding to all Member States with the entry into force of the Maastricht Treaty in 1993.

\section{After the Cold War}

The Maastricht Treaty added foreign policy to the portfolio of the newly created political union, the European Union, and sanctions was naturally added to the EU foreign policy toolbox. This regards restrictive measures adopted by the EU, as it is vastly illustrated later, but also the transposition of sanctions imposed by the Security Council of the United Nations. This has occurred in several occasions since 1993. While such decisions are transposed under CFSP legal framework, they are made neither in Brussels nor in the capitals of the Member States. There have been occasions wherein the EU has decided to enforce the regime imposed by the UN either marginally, by adding individuals and entities to the lists like in the case of international terrorism, or substantially, like in the cases of Iran or North Korea. Additionally, it has been noted how "sanctionlike" measures are frequently applied by the Council and the Commission and they do not require the adoption of CSFP decisions. First, the Cotonou Agreement - a treaty signed by the EU and the African, Caribbean, and Pacific Group of States - outlines the possibility for the EU to suspend aid and other forms of cooperation with signatory states when there are human rights concerns in the partner country as outlined by Article 96 of the agreement. ${ }^{8}$ Second, others have pointed out that the suspension of the General System of Preference (GSP) status has been applied according to logic that is normally attributed to foreign policy decisions. ${ }^{9}$ While an argument for including these measures into the study of EU sanctions could be made, this chapter refers exclusively to restrictive measures imposed under CFSP.

The first years were rather timid when it comes to the adoption of this instrument. The first legal document imposing restrictive measures was adopted on October 28, 1996, and it was about imposing sanctions on Burma/Myanmar. ${ }^{10}$ Ever since, the European Union has imposed autonomous sanctions in 33 occasions, including also those cases where the EU had acted before the United Nations, such as the cases of South Sudan and Sudan. ${ }^{11}$ The European Commission indicates that the EU's wider objectives for the utilization of sanctions are: promoting international peace and security, preventing conflicts, defending democratic principles and human rights, preventing the proliferation of weapons of mass destruction (WMDs), and fighting terrorism. ${ }^{12}$ In previous works, EU sanctions have been classified similarly as indicated in Table 7.1. ${ }^{13}$ 
Table 7.1 EU restrictive measures divided per type of crisis since $1993^{\text {** }}$

\begin{tabular}{lllll}
\hline $\begin{array}{l}\text { Conflict } \\
\text { Management }\end{array}$ & $\begin{array}{l}\text { Democracy } \\
\text { Promotion }\end{array}$ & Nonproliferation & Post-conflict & Terrorism \\
\hline Afghanistan & Belarus & DPRK & Bosnia \& & Libya \\
DRC & Burundi & Iran & Herzegovina & Terrorist list \\
Indonesia & Comoros & Libya & Ivory Coast & \\
Libya & CAR & & Egypt & \\
Sudan & China* & FRY & \\
South Sudan & Guinea (Conakry) & FYROM & \\
Transnistria & Guinea-Bissau & Guinea & \\
Russian & Iran & ICTY indictees & \\
\multicolumn{1}{c}{ Federation } & Myanmar/Burma & Libya & \\
& Nigeria & Tunisia & \\
& Sudan & Zimbabwe & \\
& Syria & & \\
& Uzbekistan & & \\
& US & & \\
& Venezuela & & & \\
& Zimbabwe & & & \\
\end{tabular}

* The restrictive measures on China are only politically binding.

*** Classification done by the author for descriptive purposes only. ${ }^{14}$

The most frequent justification for the utilization of sanctions is democracy promotion (also understood as human rights promotion). The violation of democratic practices has been used to justify the imposition of sanctions in cases where national authorities were deemed responsible for the violation of human rights of their own people, such as in the cases of Belarus and Uzbekistan. However, the unlawful overthrow of governments and elections not declared free and fair have been also reasons to trigger sanctions against individuals and nonstate entities in certain countries, such as the Central African Republic and Zimbabwe. Restrictive measures have been adopted to contain the capacities of the DPRK and Iran to develop nuclear and missile programs, but sanctions have also been used to manage ongoing conflicts such as the cases of Transnistria, Libya, the Russian Federation, and Syria. Restrictive measures have been used after the end of conflicts with the aim to contain the activities of spoilers and to consolidate the establishment of new institutions and/or governments. This was the case for Liberia and the Ivory Coast, as well as the travel ban and the freeze of assets imposed on individuals indicted by the International Criminal Tribunal for the former Yugoslavia (ICTY). ${ }^{15}$ Sanctions against persons considered to be responsible for the misappropriation of State funds in Egypt, Ukraine, and Tunisia have been also imposed after the change of government to facilitate asset recovery. ${ }^{16}$ Despite the very different regions and contexts in which restrictive measures were adopted, the legal and administrative systems in place to design and adopt restrictive measures are the same, and the following paragraph presents them in detail. 


\section{Current legal and administrative system}

\section{Legal framework}

The adoption of restrictive measures is done via the utilization of two legal instruments that are typical for the EU legal system: decisions and regulations. Decisions are imposed on an ad hoc basis; they are binding for Member States and are the legal instruments used by the EU to act in foreign policy matters. Regulations are directly binding for state and nonstate actors within the Union, and they are used when the same law needs to apply to everyone in the common market. Regulations implement the measures contained in the Council decisions within the EU.

Sanctions are adopted on the basis of chapter two of the Treaty of the European Union, which contains specific provisions on the Common Foreign and Security Policy. Article 29 is the legal basis for Council Decisions setting up sanctions regimes. The proposal for new restrictive measures comes from the High Representative of the Union for Foreign Affairs and Security Policy (HR), but restrictive measures are not only a CFSP matter. The Lisbon Treaty indicates the policy areas where the $\mathrm{EU}$ and the member states have exclusive competences, and the policy areas where the competence is shared between the EU and the member states (Articles 4, 5, and 6, TFEU). The imposition of restrictive measures regards competences that require different levels of EU involvement. For instance, the EU is the main responsible for a common commercial policy (exclusive), it coordinates with Member States on the functioning of the internal market (shared) and it assists states in administrative cooperation (supportive). Especially, since security remains in the hands of Member States in the EU institutional architecture, access to territory is still decentralized at the level of national governments.

Thus, since the imposition of sanctions affects the regular functioning of the Union's economic and financial relations with a third country, the Council needs to adopt regulations to regulate the functioning of the common market as indicated in Article 215 of the TFEU, which forms the legal basis for the Council Regulation. This indicates that when a decision to impose restrictive measures is taken, then the "Council, acting by a qualified majority on a joint proposal from the High Representative and the Commission, shall adopt the necessary measures" and "shall inform the European Parliament" (Article 215, TFUE).

The Treaty of Lisbon distinguishes between restrictive measures in external relations as mentioned earlier and restrictive measures to fight terrorism within the borders of the European Union. In such case, Article 75 reserves a central role of the European Parliament since it establishes that

the European Parliament and the Council, acting by means of regulations in accordance with the ordinary legislative procedure, shall define a framework for administrative measures with regard to capital movements and payments, such as the freezing of funds, financial assets or economic gains belonging to, or owned or held by, natural or legal persons, groups or non-State entities. 
This is considered as a measure related to internal security (Area of Freedom, Security, and Justice), so decisions falling under Article 75 will not be considered further in this chapter due to the focus on CFSP sanctions.

Restrictive measures mainly consist of economic boycotts, financial restrictions, travel bans, and arms embargoes. Both economic and financial measures are adopted with Council decisions and implemented with Council regulations, which have immediate effect in the European Union and, therefore, Member States as well as firms and individuals must comply with them. Economic boycotts entail the prohibition to sell specific products or services to a targeted country, region, company, and/or individual. Financial sanctions include the freezing of assets and the prohibition of providing loans and making payments to certain persons and entities.

When Council decisions impose arms embargoes and travel bans, then national legislation is needed because it concerns national competences. As indicated earlier, arms and access to the territory are areas wherein the Treaty of Rome granted special authority to Member States. Travel bans restrict access to the territories of the Member States and therefore to the European Union. Arms embargoes prohibit the sale of weapons and related technology or services to individuals, nonstate entities, and state entities. The prohibition to sell arms was initially limited to military goods, but it was soon evident that several goods and technologies produced for civilian use could also be utilized with military objectives. The EU recognized this problem by delegating the final decision to Member States, but a list of dual-use goods was adopted in 2009 to harmonize the activities of the national authorities of EU Member States, ${ }^{17}$ but the most updated version was approved in 2017. ${ }^{18}$ Exporters who think that certain goods might fall under such list need to apply for an export license by the competent national authorities, such as the Ministries for Economics and Foreign Affairs in their own Member State.

There are three main documents that discipline the use of sanctions by the EU. First, sanctions are imposed according to tenets illustrated in the "Basic Principles" adopted in 2004. ${ }^{19}$ Second, sanctions are designed and imposed according to ideas that are listed in the "Guidelines" adopted in 2018 in its latest versions. ${ }^{20}$ This document states that the European Union has adopted a "targeted" approach, meaning that sanctions were designed to minimize the impact on civilians while increasing the burden on certain actors, namely targeted individuals, political parties, and governmental leaders. Finally, given that imposing sanctions on individuals is extremely detailed, the third document indicates "Best Practices" on homogenous implementation of EU decisions across Member States that has been updated overtime with its most current version in May 2018. ${ }^{21}$

Although CFSP does not fall under the competence of the Court of Justice, restrictive measures have been increasingly reviewed by the Court in the past years. Shortly after the terrorist attacks of September 11, several individuals were targeted by EU financial restrictions, which were implementing the economic sanctions imposed by the United Nations. ${ }^{22}$ Some of those individuals decided to challenge the decisions in European courts. The Kadi judgements in 2005 and, especially, 2008, were the first ones wherein the Court of the European Union 


\section{Francesco Giumelli}

decided that restrictive measures, even when imposed by the Security Council, could have not been implemented by the EU when in violation of basic rights ensured by European laws. ${ }^{23}$ Since then, decisions on restrictive measures need to consider the potential infringement of due process principles, such as the right to be informed and the effective remedy assigned to listed individuals and entities. ${ }^{24}$ It is not by accident that Article 215 authorizes the EU to impose sanctions "against natural or legal persons and groups or non-State entities," but it specifies under paragraph three that such measures "shall include necessary provisions on legal safeguards" (Article 215, TFUE). The Court of Justice of the EU receives even today several complaints, and decisions of annulment of EU decisions are not rare.

\section{Actors}

\section{(1) Council of Ministers}

When it comes to restrictive measures, the EU machinery is made complex by the inter-pillar nature, to use jargon from the Maastricht Treaty, of this foreign policy instrument. The political initiative can originate from Conclusions of the European Council, such as in the case of Russia, but they can also be decisions taken in Council subcommittees such as COREPER, PSC, and the working party concerned. by the Council of Ministers. The HR submits a proposal to the Council of Ministers, which is the institution that legally formalizes the adoption of restrictive measures under the Foreign Affairs Configuration (FAC) when ministers of foreign affairs meet. There are four sub-committees of the Council where sanctions are explored and technically prepared.

The Political and Security Committee (PSC) of the Council discusses the general lines for CFSP and, as such, it could consider the opportunity to resort to restrictive measures in the different political crises. The PSC is the place where strategic considerations are assessed by the Permanent Representatives of Member States in Brussels and the political options to pursue one or another objective would be discussed and matched with the appropriate strategy to achieve it/them. This is the locus wherein sanctions are agreed upon within the limits and the boundaries set by the European Council and the Council of Ministers.

The relevant regional group of the Council is consulted for specific knowledge regarding the imposition of new measures. The Council has nine regional working parties: Transatlantic Relations (COTRA), Eastern Europe and Central Asia (COEST), Western Balkans Region (COWEB), Middle East/Gulf (MOG), Mashreq/Maghreb (MAMA), Africa (COAFR), African, Caribbean and Pacific (ACP), Asia-Oceania (COASI), and Latin America and the Caribbean (COLAC). Geographical desks provide the necessary political context, and they can also recommend the imposition of sanctions or individual listings and the listings suggested by Member States are also submitted to geographical desks. Sanctions can also be discussed in horizontal groups COMET (terrorism) and CONOP (chemical weapons). 
The Working Party of Foreign Relations Counsellors (RELEX) discusses the legal aspects of the matter based on the draft legal acts transmitted by the HR (draft decision) and the HR/Commission (draft regulation). RELEX is composed of the diplomatic representatives of the Member States permanent representations in Brussels and by the Commission (see the following). RELEX meetings are chaired by the rotating President and are attended by EEAS representatives as well. In RELEX, legal considerations are accompanied by the political and economic aspects of the restrictive measures. Once sanctions are decided, RELEX can convene under the formation called "sanctions" since 2004, which is tasked to monitor the implementation of the restrictive measures across the Union.

Finally, the draft texts agreed in RELEX are sent to the Committee of Permanent Representatives (COREPER II), which is attended by heads of missions, for the final checks before the text goes to the Council for final approval. However, normally a discussion is not necessary at this stage, so the final legal acts are submitted to and adopted by the Council of Ministers.

It is good to remember that since the imposition of restrictive measures falls under CFSP, the EU Parliament does not play a role in the decision-making process.

\section{(2) $E E A S$}

The European External Action Service (EEAS) was created to facilitate the coordination of the foreign policy of the Member States. Indeed, it is the HR, as head of the EEAS, who makes proposals for the adoption of sanctions. The EEAS drafts Council decisions that are sent to RELEX for discussion.

The EEAS has a sanctions policy division that falls directly under the SecretaryGeneral. The sanctions policy division is responsible for the overall coordination of EU sanctions policy and CFSP sanctions regimes and ensures that the legal texts are coherent and consistent across the EU. The unit plays a central role in all phases of sanctions, from their design to their application.

The EEAS also provides the Council with regional expertise that is necessary to design restrictive measures. This role is relevant to reassert the principle according to which decisions would be made in the interest of the EU. For instance, if sanctions are to be imposed on a third party upon the request of one or more Member States via the HR, the geographical desk(s) under the five regional divisions would be involved to provide comments and/or opinions on, for instance, the effectiveness and utility of sanctions in the specific context at hand. Especially, restrictive measures can have multiple and diverse effects in the local dynamic where targets are located, therefore EU delegations, geographical desks, and the Commission (see the following) can remark on whether sanctions have, among other things, unintended and/or unwanted consequences as well.

\section{(3) European Commission}

Given that restrictive measures are alteration of the functioning of the market, the Commission is included in the formal and informal discussions about sanctions. 


\section{Francesco Giumelli}

For instance, the Commission drafts Council regulations that are sent to RELEX for discussion together with Council decisions drafted by the EEAS. The Commission participates also in the process with the Service for foreign policy instrument (FPI). FPI represents the Commission in sanctions related discussions in RELEX. In the past, the regulations to implement restrictive measures were directly drafted by the Commission, so they would be headed "Commission Regulations." Since the Treaty of Lisbon, implementing powers in foreign policy matters has returned to the Council, therefore Commission regulations are now Council regulations. However, proposals for regulations on sanctions are prepared by FPI.

Currently, the Commission can also play an essential role in providing expertise that neither the Council nor the EEAS have on the effects that sanctions have both on the targeted economy and on the European Union. For instance, it was for the Commission to draft a three-tier sanctions policy toward Russia. ${ }^{25}$ In this situation, the Commission prepared a document estimating the impact on both the EU and Russia of three different sets of sanctions. The Commission provides the competence about the internal market and the economic implications deriving from the imposition of sanctions.

\section{(4) Member States}

Resorting to sanctions is up to EU Member States in the European Council and, especially, in the Council of Ministers, where they have to vote unanimously on the adoption of Council decisions and Council regulation establishing sanctions regimes. Member States are also those that gather evidence to support listing requests for individuals and entities. The Member States' role is also crucial in other three ways.

First, the implementation of travel bans falls mainly under Member States' competences. This is due to the way in which the EU integration process evolved overtime. For instance, Member States were very adamant to maintain the control of their borders for security reasons (see paragraph that follows). While the Schengen Treaty contributed substantially to abolish cross-border controls, it also granted that States have the final say about who can access their territory. Member States can, therefore, perform border controls if security and safety reasons deem it necessary. The final decision on whether individuals can access their territory was never delegated to European institutions and, therefore, it is the responsibility of national authorities to ensure that listed individuals do not enter the European Union.

Second, the implementation of arms embargoes also falls mainly under Member States' competences since security is another issue domain for which Member States are ultimately responsible. The quintessential area wherein state sovereignty is exercised is through the control of arms' trade, which was explicitly assigned to Member States with Article 223 of the Treaty of Rome (later Article 296 and, currently, Article 346 of the Treaty on the Functioning of the European Union). In a similar fashion to travel bans, the decision to ban the sale/purchase of weapons is decided in Brussels by the Council, but the implementation of the 
ban falls under Member States' authority. However, while arms embargoes do not need EU legislations to be implemented, arms and dual-use technology have received the attention of the EU since the uneven interpretation of the bans lead to very different ways in which arms embargoes were implemented across the EU. A list of military materials has been available as early as $1958,{ }^{26}$ but the most recent version was adopted in 2009. ${ }^{27}$ Common guidelines for dual-use technology have been adopted more recently with Commission Delegated Regulation in September $2017 .{ }^{28}$ However, the implementation of the dual-use still occurs at the Member State level.

Third, the enforcement of economic sanctions, both financial and trade related restrictive measures, is delegated to competent authorities in each of the Member States. The details of the national competent authorities are indicated at the end of Council regulations, so it is up to the Member States to monitor the behavior of firms based in their countries, to carry out investigations and to determine the type of penalties for sanctions violations. The next section presents an overview of the penalties imposed across the European Union.

\section{Penalties and consequences}

A thorough study of penalties set for each type of violation in the $28 \mathrm{EU}$ Member States has not been made yet. This area is possibly the least integrated and harmonized of the sanctions cycle in the EU. There are sets of both civil and criminal offences that are foreseen in the legal systems of Member States, from companies' objective responsibilities to the criminal liability of individuals. Since penalties are set by Member States, differences can be substantial. In general, there are indications for fines that both individuals and companies would have to pay if found in violations of EU export regulations. Fines for individuals can vary from $€ 1000$ (Bulgaria) to $€ 100000$ (Germany), and they can vary for companies from $€ 10000$ (Bulgaria) to one million sterling (about $€ 900000$ in the United Kingdom). Additionally, EU Member States also consider sanctions violations a criminal offence, so similar differences can be seen across the EU, from six months (Bulgaria) to ten years (Germany) in prison. ${ }^{29}$

The Netherlands has also been active in this regard. In 2017, a former managing director of a Dutch company was sentenced for "deliberately ignoring the sanctions regime" from October 2012 to February 2015. ${ }^{30}$ More recently, a criminal investigation has been launched on seven Dutch companies for violating sanctions against Russia. The accusation indicates that companies were acting in violation of the regime by helping with the construction of the bridge connecting Russia to Crimea. According to Dutch law, individuals found in violations of EU sanctions can be sentenced to up to six years in prison and to a maximum of $€ 82000$, while companies' fines can amount to up to $€ 820000 .{ }^{31}$ For violating the same sanctions regime, a German company based in Ulm was fined $€ 190000$ for exporting machines to Russia without the required export license for dual-use goods. ${ }^{32}$

Cases of voluntary disclosure should also be noted and the SiemensTechnopromexport case is a good example for it. Technopromexport, a subsidiary 


\section{Francesco Giumelli}

of the Russian company Rostec, agreed on the purchase of gas turbines from Siemens, a German company. The turbines were intended to be installed in a power plant in Taman, a few kilometers away from Crimea, in the southern part of Russia. The sale took place in the summer of 2015, but in the fall of the same year Technopromexport resold the turbines to another Rostec subsidiary, Technopromexport LLC, for power plants in Crimea. Siemens Russia sued Technopromexport for breaching the sale contract, which indicated the prohibition to resell the turbines to Crimea based actors and/or with an end use in Crimea. ${ }^{33}$ However, three Siemens employees are now under investigation for breaching EU sanctions on Russia. ${ }^{34}$

While there is an abundance of cases available for the US Office of Foreign Assets Control (OFAC), EU cases are more difficult to find. This is due to several reasons. First, there are 28 different authorities investigating in their own areas of competence, while OFAC is a centralized institution that can more easily collect all cases. Second, the collection of data is also made more complicated by the different languages that affect/characterize the European context. Finally, this difference could also have a normative explanation. While the naming and shaming of firms is practiced in the US, the same cannot be said for the EU. In the recent years, OFAC has aggressively pursued US sanctions busters both domestically and abroad. EU based firms have not been an exception to this rule, so banks such as BNP Paribas, Intesasanpaolo, HSBC and the Royal Bank of Scotland have settled accusations for up to $\$ 8.9$ billion (USD). ${ }^{35}$ This treatment was not only given to foreign entities but also to domestic ones such as Cobham, JPmorgan, and Epsilon Electronics in 2018 only. ${ }^{36}$ Rather than who the targets are, what stands out is the OFAC public outreach when companies are accused of sanctions busting and/or reach settlements with US authorities. Indeed, OFAC publishes not only a list of companies, but it issues warnings, it announces investigations, and detailed narratives of sanctions violations are available to the wider public. On the contrary, national competent authorities of EU Member States are less likely to do this. The next section presents an overview of EU autonomous sanctions in the cases of Iran, DPRK, and Russia.

\section{Sanctions overview from Iran, DPRK, and Russia}

This section presents three cases of sanctions, two framed by the UN and one of autonomous measures, with the aim to show the activity done by the EU in the issue domain of sanctions.

\section{Iran}

Sanctions on Iran are characterized by the parallel, and often different, sanctions regimes by the United Nations, the United States, and the European Union related to the nuclear program, and human rights violations occurred to counter the 2011 protests in the country. Additionally, the recent viewpoints between the US and the EU on the JCPOA have further complicated the situation. ${ }^{37}$ 
In 2002, the international community discovered that Iran was developing a nuclear program without notifying it to the International Atomic Energy Agency (IAEA) as prescribed by the Non-Proliferation Treaty (NPT). This fostered the suspect that Iran intended to develop a nuclear program with military objectives and a dialogue was set up with Teheran. The stalemate of the negotiation led to the first imposition of UN sanctions with Security Council Resolution 1737 of December 2006, imposing a travel ban, a freeze of assets, a ban on weapons, and a ban on goods related to the nuclear and ballistic missile programs. In 2006, the EU decided to transpose the main aspects of the UN regime with minor adaptations regarding individuals and entities subjected to the travel ban and the freeze of assets. In 2010, the situation deteriorated to a point that both the US and the EU went beyond the mandate of the Security Council by extending the list of sensitive technologies, restricting the purchase of oil from Iran and limiting the provision of financial services to include reinsurance services for oil transport. ${ }^{38}$ The agreement between the US and the EU had important economic consequences for the Iranian economy with a depreciation of the currency, higher inflation rates, and lower income levels from oil sale abroad. ${ }^{39}$ The EU played an important role in this direction in three main ways. First, EUIran trade was substantially higher than the one with the US, therefore any serious attempt to affect the capabilities to develop a nuclear program of Iran should have included the EU. Second, SWIFT, the body that allows and facilitates international payments, is located in EU territory and sanctions would have been weaker without it. Finally, the reinsurance ban was extremely impactful for the trade of Iranian oil, and given that $90 \%$ of such services are provided by firms based in London, it is plausible that the role of the EU was central for the impact of sanctions.

The election of Hassan Rouhani in 2013 opened a new phase in the relations between Iran and the West, which led to the signing of the Joint Comprehensive Plan of Action (JCPOA) in July 2015. The JCPOA was signed by the E3+3 and Iran, and it was characterized by important concessions on both sides. ${ }^{40}$ On the one hand, Iran agreed to very invasive inspections and on the other, the E3+3 accepted the principle that Iran could develop nuclear technology for civilian purposes. This agreement was signed under the promise that sanctions would have been removed but with the snap back clause allowing the immediate return to UN sanctions if Iran was found in violation of the agreement.

The last phase, which is also ongoing at the time of writing, started because of the decision of the Trump Administration to withdraw unilaterally from the JCPOA. Although the IAEA confirmed in several occasions that Iran was compliant with the agreement, the US government decided not to invoke the snap back and, instead, to leave the JCPOA and return to unilateral sanctions. ${ }^{41}$ In fact, the EU and the other signatory states are actively engaged in maintaining the JCPOA in force by facilitating financial transactions of EU-based operators interested in doing business with Iran - see INSTEX system. ${ }^{42}$ The effectiveness of such an instrument is still unclear.

Not all sanctions on Iran were imposed for the nuclear program, but the violent repression of protests in 2011 also caused concerns in the international community. 


\section{Francesco Giumelli}

The EU imposed a travel ban and a freeze of assets on 32 individuals with Council Decision 235, which was extended to reach the current level of 87 individuals and one entity. ${ }^{43}$ The regime was extended in 2012 to include telecommunications monitoring, interception equipment, and equipment used for internal repression. ${ }^{44}$ These restrictive measures were not included in the agreement for the JCPOA, and it is still in force today.

\section{DPRK}

The role of the EU in the case of the Democratic People's Republic of Korea (DPRK) has been similar to the one played in the case of Iran. Once again, after the Security Council resorted to sanctions against the DPRK, the EU agreed with the US to impose additional autonomous measures going beyond the mandate of the UN. In this case, given the low level of trade between the EU and the DPRK, the contribution of the EU to the crisis is less central.

The DPRK announced its intention to leave the NPT in 2003. Several actors got together in what it would be become known as the Six-Party talks - the US, Russia, China, Japan, South Korea, and North Korea - with the objective to convince Pyongyang to reverse its decision. After three years of negotiations, North Korea orchestrated the launch of ballistic missiles in July 2006, and the Security Council responded by passing Resolution 1695 threatening the imposition of sanctions. The nuclear test of October 8, 2006, triggered the first imposition of sanctions by the Security Council with Resolution $1718 .{ }^{45}$ Ever since, the evolution of sanctions followed a recurrent pattern: negotiations started, then it encountered problems, the DPRK carried out either nuclear or missile tests, and the UN followed with more stringent sanctions. The Six-Party talks did not convene after 2009, though sanctions were strengthened in 2009 (UNSCR 1874 following missile tests in June), ${ }^{46} 2013$ (UNSCR 2087 following the missing test of December 2012), ${ }^{47}$ 2016, and 2017 (with UNSCR 2270, 2321, and 2375 following the fourth, fifth, and sixth nuclear tests by North Korea).$^{48}$ In 2018, the rapprochement between South Korea and North Korea has created the conditions for the Singapore meeting between US President Donald Trump and DPRK President Kim Jong Un, which was preceded and followed by equally historical meetings between South Korean President Moon Jae-in and President Kim in April and September. ${ }^{49}$

In this context, the EU has gone beyond the mandate of the United Nations, often in coordination with the United States, since the early stages of the sanctions regime when autonomous listings were foreseen in Common Position 795 approved shortly after the first nuclear test in $2006 .{ }^{50}$ In 2009 , the list of dual-use goods was used to authorize EU exports, which was more restrictive than the UN list and the guidelines of the Sanctions Committee. The first autonomous listing took place in 2009 with Council Decision 1002 targeting technical and financial assistance to the nuclear and missile programs of North Korea. ${ }^{51}$ Heavier sanctions followed in 2013, with the ban on aluminum, gold, diamonds, and other precious metals, as well as restrictions on financial services to banks and to the central government decided with Council Decision $88 .{ }^{52}$ Other relevant economic 
measures were decided in 2016, with the ban on import of certain minerals, such as coal and iron ore and the export of aviation fuel with Council Decision 475, among others. ${ }^{53}$ The escalation of the crisis with the new nuclear tests carried out by the DPRK in 2016 led to the imposition of possibly the most stringent EU sanctions regime, with the transposition of new economic restrictions on copper, nickel, silver, helicopters, and vessels as well as the ban on new investments in North Korea in sectors such as aerospace, metallurgy, and metalworking among others as imposed by UNSCR Resolution 2321.54 A few months later, the EU complemented the regime with a comprehensive embargo on coal, iron, iron ore, seafood, and lead, ${ }^{55}$ and remittances were also limited with Council Decision 1860 in October 2017. ${ }^{56}$ Given the combination of measures in place, enforcement became central in the recent activities of the sanctions Committee and, therefore, of the European Union. Most of the decisions taken in 2018 were to fight the illicit trafficking of goods to the DPRK and to enhance the mechanisms to monitor the ways in which the DPRK managed to circumvent the UN, US, and, thus, EU sanctions regimes.

\section{Russia}

The case of sanctions on Russia are particularly relevant because, for the first time, the EU imposed sanctions against an economically important State. ${ }^{57}$ On the one hand, the sanctions regime on Russia is made of multiple measures imposed by the European Union combined with sanctions imposed by other countries, including but not limited to the United States. On the other hand, European Union countries were more interconnected with the economy of Russia than any other country; therefore the EU had a special role in this particular case.

The crisis between the EU and Russia goes back to the street protests against the President of Ukraine Viktor Yanukovych in December 2013. Since the beginning, while the EU was very critical of the incumbent regime, Moscow did not see positively the departure of Yanukovych from Kiev. Shortly after, unknown military personnel, which have been linked to Russia, expelled Ukrainian forces and supported the new local authorities in the organization of the referendum over the independence of Crimea from Ukraine and its annexation to Russia. ${ }^{58}$ The referendum, under strong criticism from the international community, led to the Russian annexation of Crimea in March 2014, and it caused the first round of sanctions by the EU. The measures, still in force today, target a number of individuals who facilitated the referendum and the political process with a travel ban and an asset freeze, ${ }^{59}$ and it imposes sectoral sanctions against products originating and coming from Crimea in June 2014. ${ }^{60}$

In the weeks following the events in Crimea other regions in Ukraine were affected. Especially the Donbass region, with the provinces of Lugansk and Donetsk being the stage for open military confrontations between rebel forces and the Ukrainian army. Once again, the Russian Federation has been accused of openly support the rebels in the region against the forces of the government in Kiev. Based on the same principle established by the decision in March, the first 
listing for the events in the Donbass region came on April 28 with Council implementing decision 238 targeted with a travel ban and a freeze of assets. ${ }^{61}$ However, the Commission had prepared, upon request of the Council, a preliminary document to advise on possible ways to increase the pressure with a tailor-made use of sanctions if Russia did not comply with the request of the EU. The plan was constituted by three phases, being the last one a combination of sectoral sanctions directly against Russia. ${ }^{62}$ In July 2014, following the downing of the MH 17, causing the death of 283 passengers and 15 members of the crew for which Russian equipment was considered to be responsible, the Council imposed economic and financial restrictions on the Russian Federation ${ }^{63}$ which were further strengthened in September 2014. ${ }^{64}$ In a nutshell, currently the EU has frozen the assets of 155 individuals and 44 entities from Russia, prohibited the entry to the EU for 155 individuals, prohibited trade of military and dual-use goods with Russia, restricted the sale of sensitive technology in the oil sector, restricted the access to credit for 11 firms - both state and private - in Russia, and prohibited trade with Crimea. In response, Russia has imposed a ban on the import of agricultural products from the EU and other countries. ${ }^{65}$ In the case of Russia, sanctions need to be renewed every six months, and they have been renewed since July 2014, even though requests for reconsidering sanctions have been often raised due to the economic costs borne by EU countries. As mentioned earlier, the economic impact for the $\mathrm{EU}$ is the unique characteristic of this regime. It should be noted that $\mathrm{EU}$ exports to Russia decreased from $€ 119$ billion in 2013 to $€ 70$ billion in 2016. In 2018 , exports have started a slow recovery and they should reach the level of $€ 87$ billion in 2018, ${ }^{66}$ which is still short of the pre-crisis levels.

Since early 2015, the Council has tied the lifting of sanctions to the compliance of the Minsk Agreement signed on February 12 by Russian President Vladimir Putin and Ukrainian President Petro Poroshenko, thanks to the mediation of French President François Hollande and German Chancellor Angela Merkel. ${ }^{67}$ The agreements set the terms for the ceasefire and outline the steps that the parties should undertake toward the resolution of the crisis based on the territorial inviolability of Ukraine, even though Crimea is not mentioned by the agreement. However, the implementation of the agreement is still largely missing with both parties exchanging accusations for violating the agreement. As this chapter is being written, the solution is not expected anytime soon.

\section{Conclusions}

The way in which the EU resorts to restrictive measures is relevant to enhance the understanding of both how the EU works and how EU sanctions function. The process of political integration started with the Treaty of Maastricht and the inability to respond to international crises, such as the Kosovo crisis and the terrorist attacks of 9/11, which have created the conditions for the European Union to develop a restrictive measure policy since the early 2000s and to champion its more recent evolution to targeted sanctions. Currently, the EU manages more than 20 targeted sanctions regimes in three different continents to promote democracy, 
protect human rights, consolidate the transition to new regimes, and deal with more conventional challenges such as the threat to the independence of Ukraine. The analysis of the four most commonly adopted restrictive measures, namely travel bans, assets freeze, trade restrictions, and arms embargoes, have shown the peculiarity of the EU system, especially when it comes to the implementation of sanctions. All institutions and actors, both from the EU and its Member States, are involved in the process from the inception of sanctions to their monitoring and enforcement. The analysis of three of the most relevant cases of restrictive measures - Iran, the DPRK, and Russia - has provided an overview of what the EU does when it comes to sanctions, and it shed light on a few challenges that characterize sanctions regimes.

This chapter has unveiled areas for potential improvements of EU restrictive measures. On the more feasible end of the spectrum, information sharing across the EU could and should be improved. Currently, Member States operate in almost total independence from the others since the Commission and the EEAS play only a limited advising role when it comes to implementing sanctions. States could make an effort to share practices, cases, and expertise in order to (1) facilitate the work for the Member States where capacity is limited and (2) reduce the incentives for companies to exploit the different loopholes provided, willingly or unwillingly, by the different interpretations of sanctions regimes that may occur across the EU. On the more ambitious end of the feasibility spectrum, the monitoring capacity of EU institutions is dwarfed before the one exercised by OFAC. While the US has one centralized authority tasked with the job to monitor and enforce sanctions, the EU has decided to delegate this task not only to 28 different competent authorities but also to 28 different investigative and judicial systems. If EU Member States were to pool resources by creating, for instance, a European OFAC-like agency, then restrictive measures would fundamentally enhance their functioning and reduce perverse effects that they have on the market due to the divergent implementations that occur in EU Member States.

\section{Notes}

1 Joakim Kreutz, "Hard Measures by a Soft Power? Sanctions Policy of the European Union," (2005), available at <www.bicc.de/uploads/tx_bicctools/paper45.pdf>.

2 European Economic Community, "Treaty of Rome," (1957), sec. 223(1)(a), available $a t<\mathrm{https}$ ://ec.europa.eu/romania/sites/romania/files/tratatul_de_la_roma.pdf $>$.

3 Ibid., sec. 224.

4 Kreutz, supra note 1, p. 8.

5 Annemieke Gerritsma, "The Significance and Legal Implications of the Sanctions Campaign for Progressive Movements in Western Countries," Sanctions Against Rhodesia: DiplomaticFarce, or Economic and LegalMeans to Raise Moral andMaterial Supportfor theSouthernAfricanLiberationMovements(1974), availableat $<\mathrm{http}$ ://schuitemaberend. blogspot.com/2011/11/sanctions-seminar-november-1974.html>.

6 Kreutz, supra note 1.

7 Ibid.

8 European Union, "2000/483/EC: Partnership Agreement Between the Members of the African, Caribbean and Pacific Group of States of the One Part, and the European 


\section{Francesco Giumelli}

Community and Its Member States, of the Other Part, Signed in Cotonou on 23 June 2000 - Protocols - Final Act - Declarations," (2000), available at $<$ https:// eur-lex.europa.eu/legal-content/EN/ALL/?uri=CELEX:22000A1215(01)>.

9 Clara Portela, European Union Sanctions and Foreign Policy: When and Why Do They Work? (2010).

10 European Union, “96/635/CFSP: Common Position of 28 October 1996 Defined by the Council on the Basis of Article J.2 of the Treaty on European Union, on Burma/ Myanmar," (1996).

11 The number of sanctions is indicative; one account can be found at $<$ www.sanctionsmap. edu>.

12 European Union, "Sanctions," Service for foreign policy instruments (FPI), n.d., available at $<\mathrm{https}: / /$ ec.europa.eu/fpi/what-we-do/sanctions_en $>$.

13 Francesco Giumelli, "How EU Sanctions Work: A New Narrative," Chaillot Paper (2013).

14 Ibid.

15 Francesco Giumelli, Coercing, Constraining and Signalling: Explaining UN and EU Sanctions After the Cold War (2011); Giumelli, supra note 13; Francesco Giumelli, The Success of Sanctions: Lessons Learned from the EU Experience (2013).

16 Andreas Boogaerts, "Short-Term Success, Long-Term Failure? Explaining the Signalling Effects of EU Misappropriation Sanctions Following Revolutionary Events in Tunisia, Egypt, and Ukraine," Journal of International Relations and Development (2018), pp. 1-25.

17 European Union, “Council Regulation (EC) No 428/2009 of 5 May 2009 Setting up a Community Regime for the Control of Exports, Transfer, Brokering and Transit of Dual-Use Items," (2009), available at $<$ https://eur-lex.europa.eu/legal-content/EN/ TXT/PDF/?uri=CELEX:02009R0428-20171216\&from=EN>.

18 European Union, "Commission Delegated Regulation (EU) 2017/2268 of 26 September 2017 Amending Council Regulation (EC) No 428/2009 Setting up a Community Regime for the Control of Exports, Transfer, Brokering and Transit of Dual-Use Items," (2017), available at $<$ https://eur-lex.europa.eu/legal-content/EN/TXT/PDF/?u ri=CELEX:32017R2268\&from=EN>.

19 European Union, "Basic Principles on the Use of Restrictive Measures (Sanctions)," 10198/1/04, no. Generic (2004), available at $<\mathrm{http}$ ://register.consilium.europa.eu/doc/ srv?l=EN\&f=ST\%2010198\%202004\%20REV\%201>.

20 European Union, "Guidelines on Implementation and Evaluation of Restrictive Measures (Sanctions) in the Framework of the EU Common Foreign and Security Policy," 5664/2018, no. Generic (2018).

21 European Union, "Restrictive Measures (Sanctions) Update of the EU Best Practices for the Effective Implementation of Restrictive Measures," 8519/18, no. Generic (2018).

22 Thomas J. Biersteker and Sue E. Eckert, "Addressing Challenges to Targeted Sanctions: An Update of the 'Watson Report'," Watson Institute for International Studies (2009).

23 Joris Larik, "The Kadi Saga as a Tale of 'Strict Observance' of International Law: Obligations Under the UN Charter, Targeted Sanctions and Judicial Review in the European Union," Netherlands International Law Review, Vol. 61, No. 1 (2014), pp. 23-42.

24 Biersteker and Eckert, supra note 22.

25 Valentina Pop and Andrew Rettman, "Leaked Paper: EU Options on 'Stage Three' Russia Sanctions,” EUobserver.com (July 22, 2014), available at $<$ https://euobserver. com/foreign/125075>.

26 Kreutz writes that "The list basically consisted of the products listed as part of the CoCom (Co-ordinating Committee for Multilateral Export Control) sanctions against the Soviet bloc since 1949." Kreutz, supra note 1, p. 8.

27 European Union, supra note 17. 
28 European Union, supra note 18.

29 The examples for national penalties come from Natalie Limbasan, "European Union: Global Sanctions Guide," Eversheds Sutherland (2018), available at $<$ https://sanctionsguide.eversheds-sutherland.com/countries/the-european-union/\#map-europe-title>.

30 Jikke Biermasz, Lisa van Vliet, and Marc Padberg, "Hard Jail Time for a Substantial Period After Violation EU Sanction Regulations," Kneppelhout Korthals Lawyers (April 9, 2017), available at <www.kneppelhout.com/news/ hard-jail-time-for-a-substantial-period-after-violation-eu-sanction-regulations $>$.

31 Bart Meijer, "Dutch Firms Probed for Alleged Breaches ofEU Sanctions on Russia," Reuters.com (May 4, 2018), available at <www.reuters.com/article/us-russia-netherlandssanctions/dutch-firms-probed-for-alleged-breaches-of-eu-sanctions-on-russia-idUSKB N1I5201>.

32 Euromaidan Staff Press, "German Company Fined for Violating Sanctions Regime with Russia," Euromaidanpress.com (October 1, 2018), available at <http://euro maidanpress.com/2018/01/10/german-company-fined-for-violating-sanctionsregime-with-russia/>.

33 Jack Ewing and Andrew Kramer, "Germany's Siemens Says Russian Partner Violated Crimea Sanctions," The New York Times (July 10, 2017), available at <www. nytimes.com/2017/07/10/business/energy-environment/siemens-russia-crimeaturbines.html>.

34 Alexander Hübner, "UPDATE 1-Three Siemens Employees Investigated Over Turbines in Crimea," Reuters.com (November 29, 2018), available at $<\mathrm{https}$ ://uk.reuters.com/ article/siemens-ukraine-sanctions/update-1-three-siemens-employees-investigatedover-turbines-in-crimea-idUKL8N1Y453V>.

35 Francesco Giumelli and Giulia Levi, "Sanzioni: Alle Imprese Europee La Multa Arriva Dagli Usa," Lavoce.Info (2016), available at <www.lavoce.info/archives/41389/ sanzioni-alle-imprese-europee-la-multa-arriva-dagli-usa/>.

36 OFAC, "Enforcement Information for September 13, 2018: Epsilon Electronics, Inc. Settles Potential Civil Liability for Alleged Violations of the Iranian Transactions and Sanctions Regulations and Related Claims," The Office of Foreign Assets Control (2018), available at $<$ www.treasury.gov/resource-center/sanctions/CivPen/Documents/ 20180913_epsilon.pdf>.

37 Ellie Geranmayeh, "The Coming Clash: Why Iran Will Divide Europe from the United States," European Council on Foreign Relations (2017), available at $<$ www.politico. eu/wp-content/uploads/2017/10/Why-Iran-Will-Divide-Europe-From-The-US.pdf > .

38 European Union, "Council Decision of 26 July 2010 Concerning Restrictive Measures Against Iran and Repealing Common Position 2007/140/CFSP,” (2010), p. 201.

39 Erica S. Moret, "Humanitarian Impacts of Economic Sanctions on Iran and Syria," European Security, Vol. 24, No. 1 (2015), pp. 120-140; Elena Ianchovichina, Shantayanan Devarajan, and Csilla Lakatos, "Lifting Economic Sanctions on Iran: Global Effects and Strategic Responses," Policy Research Working Papers (2016), available at $<$ https://doi.org/10.1596/1813-9450-7549>; Jamal Ibrahim Haidar, "Sanctions and Export Deflection: Evidence from Iran," Economic Policy, Vol. 32, No. 90 (April 6, 2017), pp. 319-355, available at $<$ https://doi.org/10.1093/epolic/eix002>.

40 Mark Fitzpatrick, "Assessing the JCPOA," Adelphi Series, Vol. 57, Nos. 466-467 (2017), pp. 19-60.

41 Mark Landler, "Trump Abandons Iran Nuclear Deal He Long Scorned," The New York Times (May 8 edition, 2018), available at <www.nytimes.com/2018/05/08/world/ middleeast/trump-iran-nuclear-deal.html $>$.

42 "INSTEX: Europe Sets up Transactions Channel With Iran," DW.com (January 31, 2019), available at <www.dw.com/en/instex-europe-sets-up-transactions-channelwith-iran/a-47303580>.

43 European Union, "Council Decision 2011/235/CFSP of 12 April 2011 Concerning Restrictive Measures Directed Against Certain Persons and Entities in View of the Situation in Iran," (2011). 


\section{Francesco Giumelli}

44 European Union, "Council Decision 2012/169/CFSP of March 23, 2012, Amending Decision 2010/413/CFSP Concerning Restrictive Measures Directed Against Iran," (2012).

45 U.N. Doc. S/RES/1718 (2006).

46 U.N. Doc. S.RES/1874 (2009).

47 U.N. Docs. S/RES/2087 (2012).

48 U.N. Docs. S/RES/2270 (2016); S/RES/2321 (2016); S/RES/2375 (2017).

49 Francesco Giumelli, "From Six-Party Talk to Two Man Show? An Analysis of the Nuclear Negotiation With North Korea Through Sanctions," Multilateralism at Peril, Taipei, Taiwan (2018).

50 European Union, "Council Common Position 2006/795/CFSP of 20 November 2006 Concerning Restrictive Measures Against the Democratic People's Republic of Korea," (2006), p. 795.

51 European Union, "Council Decision 2009/1002/CFSP of 22 December 2009 Amending Common Position 2006/795/CFSP Concerning Restrictive Measures Against the Democratic People's Republic of Korea," (2009).

52 European Union, "Council Decision 2013/88/CFSP of February 18, 2013, Amending Decision 2010/800/CFSP Concerning Restrictive Measures Against the Democratic People's Republic of Korea," (2013).

53 European Union, “Council Decision (CFSP) 2016/475 of March 31, 2016, Amending Decision 2013/183/CFSP Concerning Restrictive Measures Against the Democratic People's Republic of Korea," (2016).

54 U.N. Doc. S/RES/2321 (2016).

55 European Union, “Council Decisions (CFSP) 2017/1562 of 14 September 2017, Amending Decision (CFSP) 2016/849 Concerning Restrictive Measures Against the Democratic People's Republic of Korea," (2017).

56 European Union, “Council Decisions (CFSP) 2017/1860 of 16 October 2017, Amending Decision (CFSP) 2016/849 Concerning Restrictive Measures Against the Democratic People's Republic of Korea," (2017).

57 Francesco Giumelli, "The Redistributive Impact of Restrictive Measures on EU Members: Winners and Losers from Imposing Sanctions on Russia," Journal of Common Market Studies (2017), available at <http://onlinelibrary.wiley.com/doi/10.1111/ jcms.12548/full>.

58 Erica S. Moret et al., "The New Deterrent? International Sanctions Against Russia Over the Ukraine Crisis: Impacts, Costs and Further Action," (2016), available at $<$ http:/graduateinstitute.ch/files/live/sites/iheid/files/sites/internationalgovernance/ shared/The $\% 20$ New $\% 20$ Deterrent $\% 20$ International $\% 20$ Sanctions $\% 20$ Against $\% 20$ Russia\%20Over\%20the\%20Ukraine \%20Crisis\%20-\%20Impacts, \%20Costs\%20 and\%20Further\%20Action.pdf $>$; Erica S. Moret, Francesco Giumelli, and Dawid Bastiat-Jarosz, "Sanctions on Russia: Impacts and Economic Costs on the United States," (2017), available at $<$ http://graduateinstitute.ch/files/live/sites/iheid/files/sites/ internationalgovernance/shared/Russian-Sanctions-Report.pdf>; Francesco Giumelli, "Quando Sono Utili Le Sanzioni Internazionali? L'Italia, La Russia e l'Unione Europea," Approfondimenti (2018), available at <www.iai.it/sites/default/files/pi_a_0142. pdf $>$.

59 European Union, “Council Decision 2014/145/CFSP of March 17, 2014, Concerning Restrictive Measures in Respect of Actions Undermining or Threatening the Territorial Integrity, Sovereignty and Independence of Ukraine," (2014).

60 European Union, "Council Decision 2014/386/CFSP of 23 June 2014 Concerning Restrictions on Goods Originating in Crimea or Sevastopol, in Response to the Illegal Annexation of Crimea and Sevastopol," (2014).

61 European Union, “Council Implementing Decision 2014/238/CFSP of 28 April 2014 Implementing Decision 2014/145/CFSP Concerning Restrictive Measures in Respect 
of Actions Undermining or Threatening the Territorial Integrity, Sovereignty and Independence of Ukraine," (2014).

62 Pop and Rettman, supra note 25.

63 European Union, "Council Decision 2014/512/CFSP of 31 July 2014 Concerning Restrictive Measures in View of Russia's Actions Destabilising the Situation in Ukraine," (2014).

64 European Union, "Council Decision 2014/659/CFSP of 8 September 2014 Amending Decision 2014/512/CFSP Concerning Restrictive Measures in View of Russia's Actions Destabilising the Situation in Ukraine," (2014).

65 Moret et al., supra note 58.

66 Giumelli, "Quando Sono Utili Le Sanzioni Internazionali?" supra note 58.

67 Matthew Weaver and Alec Luhn, "Ukraine Ceasefire Agreed at Belarus Talks," The Guardian (February 12 edition, 2015), available at <www.theguardian.com/ world/2015/feb/12/ukraine-crisis-reports-emerge-of-agreement-in-minsk-talks $>$. 


\title{
8 Implementation of sanctions Japan
}

\author{
Machiko Kanetake
}

\section{Introduction}

Economic sanctions are one apparatus available for States and international organizations to coercively steer other countries and nonstate actors in certain policy directions, yet not all States with economic and political leverage consider economic sanctions their own unique means to pursue political agendas. The US government notably situates economic sanctions as its own strategic foreign policy tools, through which it exerts its political and economic leverage. ${ }^{1}$ Economic sanctions also constitute a proactive element of the EU's common and foreign security policy. ${ }^{2}$ By contrast, at least until the beginning of the twenty-first century, the Japanese government had not fully characterized economic sanctions as part of its autonomous policy options. Instead, economic sanctions had been applied within the framework of the UN or the initiatives of like-minded States as part of Japan's "international cooperation."

Nevertheless, the traditionally modest assumption that the Japanese government had about economic sanctions has undergone a proactive change. This has happened in response to a series of ballistic missile tests by North Korea since the mid-1990s, which has helped shift the domestic political climate in favor of the more proactive use of economic sanctions in order to safeguard the country's own security. Such a proactive turn came on July 5, 2006, when the Japanese government applied its first unilateral sanctions outside the framework of international cooperation that had traditionally confined the scope of such coercive measures. ${ }^{3}$

Against this background, this chapter aims to provide an overview of Japanese approaches to economic sanctions from both legal and political standpoints. The chapter begins by providing the political background that has defined the Japanese approach to economic sanctions (Section I). The chapter then goes on to examine the legal and administrative frameworks for applying economic sanctions (Section II). This will be followed by specific analyses of how the Japanese government instigated economic sanctions against North Korea outside the UN Security Council's enforcement measures (Section III-1). The chapter also gives an account of the piece of legislation that Japan adopted in 2014 to give effect to the UN's counterterrorism sanctions. Internationally, or at least within the EU, the implementation of the UN's counterterrorism sanctions gave rise to the concern 
that the designation of specific targets disregarded norms of due process. ${ }^{4}$ In the Japanese legal and political discourse, however, the issue of due process attracted little attention (Section III-2). By accounting for economic sanctions through the lens of the Japanese political and legal contexts, this chapter highlights how international political pressures necessitated and justified greater changes in domestic legal practices.

\section{Development of Japan's cooperative and proactive approaches to sanctions}

As noted in the introduction, the Japanese government's approach to economic sanctions has traditionally been characterized by the spirit of international cooperation. Until the beginning of the twenty-first century, economic sanctions had not been considered part of the government's autonomous foreign policy instruments. In principle, economic sanctions have been adopted to implement the sanctions regimes adopted by the UN Security Council. While the government has applied certain restrictive measures outside the UN's framework, such measures have followed the international initiatives taken by other major States. For instance, during the Gulf War in 1991, the Japanese government employed economic sanctions against Iraq before the UN Security Council adopted Resolution 661 and imposed nonmilitary enforcement measures under Chapter VII of the UN Charter, ${ }^{5}$ yet Japan's non-UN measures against Iraq at that time still fell under the framework of international cooperation, inasmuch as they were in line with the initiatives of the US government and several other like-minded States. ${ }^{6}$

In the spirit of international cooperation, the Japanese government was still reluctant to impose autonomous economic sanctions even in the wake of a series of provocations by North Korea from 1993-1994. ${ }^{7}$ On March 12, 1993, North Korea declared its intention to withdraw from the Nuclear Non-Proliferation Treaty. ${ }^{8}$ On May 29 and 30, the country launched a Nodong-1, a medium-range ballistic missile, into the Sea of Japan. Despite the calls of the International Atomic Energy Agency (IAEA) to accept comprehensive safeguards according to its Safeguard Agreement, ${ }^{9}$ North Korea took steps to defuel a research reactor in May $1994 .{ }^{10}$ Nevertheless, this series of provocations did not lead to autonomous economic sanctions by Japan outside the framework of the UN and like-minded States.

The Japanese government's alignment with international initiatives is reflected in the country's domestic legal framework on economic sanctions. Japan does not have general enabling legislation equivalent to the United Nations Act 1946 in the UK or the United Nations Participation Act 1945 in the US to implement the UN's economic sanctions regimes. ${ }^{11}$ Instead, Japan implements them on a patchwork basis by applying existing pieces of legislation, which have a much wider use than in the context of economic sanctions. The main legal basis to give effect to economic sanctions is the Foreign Exchange and Foreign Trade Act ("FEFT Act"). ${ }^{12}$ The act was enacted in 1949 for the sake of ensuring equilibrium in the international balance of trade and currency stability by controlling foreign exchange, foreign trade, and other foreign transactions. ${ }^{13}$ 
Initially, the FEFT Act was designed for the pursuit of economic objectives, as opposed to the maintenance of international peace and security. The problem with legislative objectives of an economic nature became apparent in the COCOM case that was decided by the Tokyo District Court in $1969 .{ }^{14}$ In this case, the plaintiff was a group of manufacturers called Nikkoten that applied for governmental approval of the export of certain goods to the People's Republic of China for display at the Beijing-Shanghai Japanese Industrial Exhibition. The Minister of International Trade and Industry (MITI) at the time declined to approve the request, inasmuch as the goods in question fell under the controlled materials of the COCOM (Coordinating Committee for Multilateral Export Control), which was the Western Bloc's export control regime during the Cold War. Under the COCOM, the scope of controlled items was formulated in the context of a competition of military capability between the Western and Soviet Union blocs as a set of strategic items. ${ }^{15}$ One of the questions raised by the plaintiff was whether the minister's decision fell within the purview of the Export Trade Control Order, an administrative instrument enacted according to the FEFT Act. Under the Order, the Minister could deny an export license if it was found necessary for ensuring "the maintenance of equilibrium in the international balance of trade and the sound development of foreign trade and national economy." 16 In the 1969 decision, the Tokyo District Court observed that the denial of approval was not for the sake of economic rationales as envisaged in the Order, but instead in the pursuit of international political objectives. Accordingly, the Tokyo District Court found that the Minister had acted illegally, going beyond the bounds of his discretionary power.

The decision of the Tokyo District Court in 1969 did not immediately lead to the fundamental modification of the FEFT Act. It was only in 1979 that the Japanese Diet amended the act to better align its objectives with those of economic sanctions. The 1979 amendment, which became effective in 1980, allowed the government to restrict capital and service transactions if they "prevent the sincere fulfilment of treaties and other international agreements Japan has concluded" or "impair international peace and security." 17 At least with respect to capital and service transactions, this amendment formally acknowledged noneconomic objectives as grounds for imposing licensing requirements. In this regard, the amendment has altered the basic characteristics of the FEFT Act. ${ }^{18}$ At the same time, the 1979 amendment did not go as far as adding noneconomic objectives with regard to the export restriction of goods in general. ${ }^{19}$ The overall aim of the FEFT Act, as articulated in Article 1, also remained confined to that of an economic nature. ${ }^{20}$

A further legislative change came in 1987, after substantial political backlash against Toshiba Machine Co. involving the company's breach of COCOM rules. It was revealed in 1987 that the firm had exported parts and computer programs for propeller milling machines to the Soviet Union without obtaining the approval of the MITI. The controversy stemmed from the fact that the exported items could have been used to cut submarines' propellers and make their operation quieter and more difficult to detect. Amid the Cold War, the revelation triggered an outcry 
in the US. The New York Times criticized the "avarice" of Toshiba and the Japanese government's "lackadaisical supervision" of militarily sensitive exports. ${ }^{21}$ The incident eventually led the Tokyo District Court to impose a fine on Toshiba Machine Co. and order the imprisonment of its two senior staff. ${ }^{22}$ In response to political pressure, the Japanese government amended the FEFT Act in 1987 in order to allow "the maintenance of international peace and security" as one of the bases for restricting the export of goods, ${ }^{23}$ and it introduced a more stringent penalty for noncompliance. ${ }^{24}$ Still, however, the overall economic purpose of the FEFT Act, as provided in Article 1, remained unchanged. This was presumably because of the assumption that restrictions on the freedom of foreign exchange should be kept to a minimum. Namely, to alter Article 1 and expand the act's overall aim would have invited criticism that the government was overly restricting such freedom in the name of international peace and security.

In 2004, Article 1 of the FEFT Act was amended to embrace the element of "peace and security" as part of its overall legislative purpose. The amendment formally added "the maintenance of peace and security in Japan and in the international community" to Article $1 .^{25}$ The 2004 amendment marked an important turning point, not only because of the changes in the overall economic narrative but also due to the novel reference to peace and security "in Japan." Namely, the amendment allowed the government to restrict foreign payment, capital, and service transactions, outward direct investment, or the export of goods when such restriction would be particularly necessary for the maintenance of national - not just international - peace and security. ${ }^{26}$ Such an extension gained political support, especially since the incident in December 2001, involving the exchange of fire between Japanese Coast Guard vessels and an unidentified ship that turned out to be a North Korean spy vessel. ${ }^{27}$ On July 5, 2006, the Japanese government instigated its unilateral sanctions against North Korea, as will be described further in Section III. This marked the first proactive sanctions that the Japanese government had applied outside the UN's sanctions measures and beyond the framework of international cooperation with like-minded States.

\section{Legal and administrative frameworks}

\section{Statutory and executive orders}

\section{(1) Foreign exchange act}

As overviewed in the previous section, the FEFT Act has been the basic vehicle through which the Japanese government has applied not only sanctions adopted by the UN Security Council or like-minded States but also those autonomously initiated by the Japanese government. There are several key provisions of the Foreign Exchange Act relevant to the application of economic sanctions, including the implementation of UN sanctions regimes.

To begin with, Article 16(1) of the FEFT Act allows the government to restrict payments to a foreign State or nonresident. ${ }^{28}$ Article 16(1) is implemented 
together with Article 6(1) of the Foreign Exchange Order ("FE Order") issued by the Cabinet. ${ }^{29}$ Under these provisions, the Minister of Finance or the Minister of Economy, Trade, and Industry may impose an obligation on a resident or nonresident to obtain permission to engage in making a designated payment to a foreign State or to a nonresident. ${ }^{30}$ For instance, following the establishment of the UN's sanctions on Libya in February 2011 under Resolution 1970, ${ }^{31}$ the Ministry of Foreign Affairs (MOFA) published a list of individuals designated as targets of asset freeze measures. ${ }^{32}$ The MOFA's notice was accompanied by a public notice from the Ministry of Economy, Trade, and Industry (METI, formerly MITI) that required permission for making payments involving the listed individuals. ${ }^{33}$

On top of the payment restriction, Article 21(1) of the FEFT Act provides the basis for restricting capital transactions within the framework of economic sanctions. ${ }^{34}$ Together with Article 11(1) of the FE Order, Article 21(1) of the FEFT allows the Minister of Finance to implement international or Japanese autonomous sanctions by imposing an obligation on a resident or nonresident to obtain permission to engage in designated capital transactions. ${ }^{35}$ In addition, with regard to "specified capital transactions," the Minister of Economy, Trade, and Industry is in charge of imposing a requirement to obtain permission according to Article 24(1) of the FEFT Act and Article 15 of the FE Order. ${ }^{36}$ Such capital transactions are those that directly accompany the import or export of goods or that pertain to the transfer of mining or industrial property rights. ${ }^{37}$ For instance, on November 7 , 2014, the UN Security Council's Sanctions Committee on Yemen designated three individuals as targets of asset freeze and travel ban measures under UN Security Council Resolution 2140. ${ }^{38}$ After the adoption of the resolution, the MOFA of Japan published, on December 17, 2014, the list of the designated individuals, ${ }^{39}$ and, pursuant to the METI's public notice released on the same day, it became mandatory to seek permission from the Minister of Economy, Trade, and Industry for specified capital transactions pertaining to the designated individuals. ${ }^{40}$

Likewise, "service transactions" can also be subject to restrictions in giving effect to UN sanctions, those instigated by like-minded States, and Japan's autonomous sanctions. For instance, in October 2006, the UN Security Council instigated economic sanctions against North Korea. ${ }^{41}$ Under paragraph 8(c) of Resolution 1718, Member States were required to prevent any transfers, to or from North Korea, of technical training, advice, services, or assistance regarding the manufacture or use of military items. ${ }^{42}$ The Japanese government imposed the requirement to obtain permission with regard to such service transactions according to Article 25(6) of the FEFT Act and Article 18(3) of the FE Order. ${ }^{43}$

Finally, if sanctions regimes aim to restrain the export and import of goods in general, Article 48 of the FEFT Act serves as a basis for restricting exports, while Article 52 provides a ground for regulating imports. ${ }^{44}$ Article $48(1)$ of the act provides the legal basis for regularly applied export control over military and dualuse items as listed in the Export Trade Control Order. ${ }^{45}$ In addition, Article 48(3) of the act can cover a wider range of goods subject to export control, which allows the government to give effect to export restrictions under UN sanctions, those initiated by like-minded States, and Japan's autonomous economic sanctions. ${ }^{46}$ 
Import restrictions are given effect by the Import Trade Control Order ${ }^{47}$ and the METI public notices issued in accordance with the Control Order.

\section{(2) Other legal frameworks}

The FEFT Act, however, does not serve as an adequate legal basis for certain circumstances envisaged by UN sanctions. ${ }^{48}$ For instance, in the early 1990 s, the limitations of the FEFT Act became evident in the context of implementing the Yugoslavia sanctions regime under UN Security Council Resolution 820. The resolution obliged all States to "impound all vessels, freight vehicles, rolling stock, and aircraft in their territories." ${ }^{49}$ As the FEFT Act is meant to regulate the cross-border transfer of capital and goods, the act did not serve as a sufficient legal basis for confiscating these properties in Japan. In the absence of appropriate legal bases, the Japanese government simply prevented the relevant properties from being present in Japan in the first place by resorting to the Immigration Control and the Refugee Recognition Act, so that the country would not be in breach of the UN sanctions. ${ }^{50}$

A more pressing limitation of the FEFT Act became evident, however, in the course of implementing the UN's counterterrorism sanctions. The UN Security Council established the so-called 1267 sanctions regime targeting specific terrorist organizations. Resolution 1267 is the first of a series of UN Security Council resolutions that imposed economic sanctions against the Taliban and, subsequently, Al-Qaeda and the Islamic State in Iraq and the Levant. ${ }^{51}$ In 2011, the 1267 sanctions regime was split into two, with one regime for Al Qaeda ${ }^{52}$ and another for the Taliban. ${ }^{53}$ On top of the specific counterterrorism regime, the UN Security Council adopted Resolution 1373 in 2001, which aimed to impose on Member States a series of general obligations to criminalize terrorist financing acts and freeze the assets of those involved in terrorist acts. ${ }^{54}$ Initially, the Japanese government relied upon the FEFT Act to give effect to the UN's counterterrorism sanctions, yet such a conventional recourse proved to be inadequate. This is precisely because the UN's sanctions regimes aim to eradicate the financing of terrorist acts by regulating not just cross-border transactions but also those of a domestic nature. ${ }^{55}$ The FEFT Act, which literally aims to regulate certain "foreign" transactions, could not be invoked by the government to restrict payment made for the benefit of its own nationals who have residency in Japan.

In November 2014, the Japanese Diet took steps to remedy the gaps between the UN's counterterrorism sanctions and Japan's legal frameworks. The Diet enacted a new piece of legislation, ${ }^{56}$ which became effective in October 2015, to implement the 1267 sanctions regime, the 1988 sanctions regime against the Taliban, and the 1373 counterterrorism measures ("2014 Counter-Terrorism Act"). The legislation was, in part, motivated and justified by external pressure from the Financial Action Task Force (FATF), which had, in its 2008 report, pointed out the "gaps" remaining in Japan's implementation of counterterrorism sanctions. ${ }^{57}$ The FATF recommended that the Japanese government "review and modify its [asset] freezing system to fully implement UNSCRs 1267 and 1373." 58 The 2014 Counter-Terrorism Act was one of the responses following the FATF's criticisms. 
Under the 2014 Counter-Terrorism Act, it became possible for the government to regulate domestic transfers involving international terrorists, at least in the course of implementing the 1267 and 1988 sanctions regimes. Under these mechanisms, the UN Security Council's sanctions committees are responsible for designating specific individuals and entities as targets of asset freezes and travel bans. In Japan, under the 2014 act, persons designated by the UN would be publicly notified ${ }^{59}$ and would be required to obtain permission from Prefectural Public Safety Commissions - which are part of the police organization - if such persons intended to receive, for example, a donation of assets subject to regulation, ${ }^{60}$ a lease of the assets, ${ }^{61}$ or a payment in consideration of the sale, loan, or other disposition of the assets. ${ }^{62}$ In turn, no one could donate or sell such assets, etc., to those designated by the sanctions regimes. ${ }^{63}$ These restrictions can be imposed even for domestic transactions conducted solely among residents in Japan. By contrast, regarding the 1373 sanctions regime (which leaves the designation of targets to each Member State), the scope of regulation is still in tune with the FEFT Act. Namely, under the 2014 act, those who are autonomously designated by the Japanese government ought to have been engaged with outbound payments or those made by residents to nonresidents. ${ }^{64}$

\section{Agencies}

When it comes to the implementation of economic sanctions, the national legislature tends to play a very limited role, and Japan is no exception in this regard. Different ministries are responsible for giving effect to UN and non-UN economic sanctions. The MOFA disseminates the general information on sanctions and publishes the list of individuals and entities designated as the targets of asset freezes and travel bans, yet the MOFA is by no means the only ministry working for the domestic implementation of economic sanctions. For instance, an entry ban on individuals is administered by the Ministry of Justice, while an entry ban on ships is controlled by the Ministry of Land, Infrastructure, Transport, and Tourism.

When it comes to arms embargo and asset freeze measures, the METI and the Ministry of Finance (MOF) are responsible for administering the FEFT Act in order to give effect to such restrictive measures. Broadly speaking, the METI is responsible for regulating restrictions on goods and services, while the MOF administers the restriction of financial transactions insofar as they do not accompany the export and import of goods. ${ }^{65}$ For example, when the UN Security Council imposed an arms embargo on Libya under Resolution 1970 in 2011, ${ }^{66}$ the Japanese METI issued a public notice in accordance with the Import Trade Control Order. ${ }^{67}$ The notice was meant to update the METI's earlier public notice, which had listed the items subject to import restrictions. ${ }^{68}$

On top of administering the export and import restrictions of goods, the METI is also in charge of specified capital transactions under Article 24(1) of the FEFT Act, insofar as such transactions are incidental to exports and imports. ${ }^{69}$ In a similar vein, the METI administers restrictions on payments under Article 16(1) of the FEFT as long as such payments are directly linked to the export or import of 
goods. ${ }^{70}$ Other payments fall under the responsibility of the MOF. ${ }^{71}$ For example, after the UN Security Council instigated asset freezes on Yemen under Resolution 2140 in $2014,{ }^{72}$ the Japanese MOFA disseminated the list of individuals designated by the Yemen Sanctions Committee. ${ }^{73}$ The METI then issued a public notice regarding the restrictions on specified capital transactions with those individuals, ${ }^{74}$ and the METI and MOF imposed further restrictions on payments to them. ${ }^{75}$

On top of these ministries regularly working for the implementation of economic sanctions, the 2014 Counter-Terrorism Act added another player within the context of implementing the UN's counterterrorism sanctions. The act essentially entrusted the National Public Safety Commission, which is part of Japan's national police apparatus, with the authority to implement the UN's 1267 and 1373 sanctions regimes. The Commission, established by the Police Act, ${ }^{76}$ aims to secure certain democratic oversight of the activities of the National Police Agency. The Commission Chairman is nominated by the Prime Minister, who also appoints the Commission's members with the consent of both houses of the Diet. The Commission then supervises the overall activities of the National Police Agency and appoints its Commissioner General as well as the chiefs of prefectural police organizations.

Under the 2014 Counter-Terrorism Act, the National Public Safety Commission has the authority to administer both UN and non-UN lists for the purpose of imposing asset freeze measures. Under Article 3 of the act, the National Public Safety Commission publicly notifies the individuals and entities designated by the UN under the 1267 and 1988 sanctions regimes. ${ }^{77}$ On top of this, under Article 4, the Commission has the authority to independently designate individuals and entities as international terrorists under Security Council Resolution $1373 .{ }^{78}$ The non-UN list is drawn up in the light of the practices of the US and other like-minded States. In October 2015, after the act entered into force, the National Public Safety Commission published a list of seven individuals and 18 entities designated as the targets of asset freeze measures according to Article 4 of the Counter-Terrorism Act. ${ }^{79}$

The central role that the police organization has in the implementation of the UN's counterterrorism sanctions fits in with the narrative of the UN that the acts of terrorism are "criminal and unjustifiable." 80 Security Council Resolution 1373 mandates that States criminalize the financing of terrorism, ${ }^{81}$ and the 1267 sanctions regime also anticipates that criminal proceedings would be taken by Member States against those listed by the 1267 Sanctions Committee. ${ }^{82}$ The UN Security Council reiterates that the restrictive measures under the 1267 sanctions regimes are "preventive in nature" without relying on national criminal standards. ${ }^{83}$ Yet, in practice, the UN's sanctions list has been helping Member States' authorities to establish the involvement of designated individuals in terrorism under domestic criminal proceedings. ${ }^{84}$ The UN Security Council's narrative, which combines its targeted sanctions with domestic criminal proceedings, is reflected in the counterterrorism legislation in Japan, which has empowered the body in charge of overseeing the country's police system.

The responsibilities entrusted to various executive bodies come with the limited presence of parliamentary oversight in this field of law and politics. While this is 
not surprising, there are certain issues that demand greater democratic input. It must be noted that the 2014 Counter-Terrorism Act does not contain any provision that obliges the relevant ministries to report to the Diet. The limited involvement of the legislative body is problematic, especially in light of the fact that the counterterrorism legislation may impose significant restrictions on the fundamental rights of individuals subject to asset freeze measures, as will be further discussed in Section III-2 of this chapter.

\section{Penalties and consequences}

The violations of restrictive measures that give effect to economic sanctions can trigger both criminal penalties and administrative dispositions. Over the years, the penalties have been strengthened by a series of amendments to the FEFT Act, which reflects the greater political weight given to the prevention of export control violations. Should a person export goods without obtaining the necessary permission under Article 48(3) of the FEFT, the person is subject to imprisonment for up to five years, a fine of up to $¥ 10$ million ( $\$ 90,090$ USD), or a combination of both. ${ }^{85}$ The maximum fine may be higher if the amount of five times the price of the exported goods exceeds $¥ 10$ million. ${ }^{86}$ The maximum fine was doubled by the amendment of 2017. ${ }^{87}$ If a payment is made without the necessary permission under Article 16(1) of the FEFT Act, the violation triggers a punishment of imprisonment for up to three years or a fine of a maximum of $¥ 1$ million $(\$ 9,091)$ (or three times the value of the transaction) ${ }^{88}$ On top of these penalties, corporations may face a fine of a maximum of $¥ 500$ million ( $\$ 4.5$ million) or five times the price of the items in question. ${ }^{89}$

In addition to these penal measures, the METI Minister can take administrative dispositions against those who have exported or imported goods without the necessary license. The METI can prohibit them from exporting or importing goods for up to three years..$^{90}$ The 2017 amendment extended the maximum duration of the administrative disposition from one year to three. ${ }^{91}$ Dispositions would be published on the METI's website, as a result of which the companies or individuals involved would suffer from reputational sanctions in practice.

There are several cases in which violations of the FEFT Act have led not only to administrative sanctions prohibiting exports but also to criminal convictions. ${ }^{92}$ For example, in 2009, a representative director of a secondhand car sales company was arrested for an alleged violation of the FEFT Act. ${ }^{93}$ The director reportedly exported two tank trucks to North Korea in 2008 in breach of the Japanese export control regulation. Such trucks were subject to export control, as they could have been used as missile launchers. The director also exported 34 pianos to North Korea, despite the prohibition imposed on the export of "luxury goods" to North Korea, according to UN Security Council Resolution $1718 .{ }^{94}$ In response, the METI prohibited the company from exporting any goods for a duration of 16 months from February 2010. Eventually, the director was sentenced to three years in prison, and the company was subject to a fine of $¥ 5$ million $(\$ 45,455)$. 


\section{Implementation of sanctions}

\section{North Korea}

As mentioned in Section II, one of the turning points in the Japanese approach to economic sanctions came in July 2006, when the government initiated unilateral sanctions against North Korea. ${ }^{95}$ The Japanese government applied its autonomous sanction in response to North Korea's launch of a series of ballistic missiles on July 5, 2006. Shortly after the launch of missiles, the Japanese government took steps to ban the entry of a North Korean cargo-passenger ship (Man Gyong Bong 92) into Japanese ports. ${ }^{96}$ The government also prohibited the entry of North Korean officials and decided to assess the entry of non-officials in a more stringent manner. These entry bans were the first proactive sanctions that the Japanese government took outside the initiatives of the UN or like-minded States. While the UN Security Council also condemned the launch of missiles by North Korea, it did not go as far as imposing economic sanctions. ${ }^{97}$ The UN Security Council merely requested that Member States prevent the transfer of any financial resources in relation to North Korea's missiles or its weapons of mass destruction (WMD) programs. ${ }^{98}$ This request was, nevertheless, still given effect by the Japanese government, which imposed restrictions on payment and capital transactions with respect to 15 specific entities and one individual involved in the development of missiles or WMDs. ${ }^{99}$

In October 2006, the unilateral sanctions were further expanded in response to North Korea's first nuclear test on October 9. On October 13, the Japanese government extended the entry ban to all North Korean vessels. ${ }^{100}$ This was accompanied by a general import ban on goods originating in North Korea ${ }^{101}$ as well as restrictions on service transactions ${ }^{102}$ and payments. ${ }^{103}$ An entry ban was also introduced with respect to North Korean nationals except under special circumstances. ${ }^{104}$ After North Korea conducted its second nuclear test on May 25, 2009, the Japanese government imposed a general export ban on goods destined for North Korea, ${ }^{105}$ except for those for humanitarian purposes. ${ }^{106}$ The autonomous export ban was much more comprehensive than the bans imposed under UN Security Council Resolutions 1718 and 1874, according to which UN Member States were obliged to prevent the export of "luxury goods" as well as other materials, goods, and technology related to weapons of mass destruction. ${ }^{107}$ In June 2010, a special piece of legislation was also introduced to strengthen the inspection of cargo bound to, or originating in, North Korea that contained materials relevant to weapons of mass destruction or weapons. ${ }^{108}$ This special legislation was in line with UN Security Council Resolution 1874, which calls on Member States to inspect cargo, not only within their territory but also "on the high seas," if States have information that provides reasonable grounds to believe that the cargo contains prohibited materials. ${ }^{109}$ Japan's special legislation allows the Japan Coast Guard to inspect the cargo of a vessel on the high seas, with the consent of the flag State, ${ }^{110}$ if there are reasonable grounds to believe that the vessel carries cargo consisting of prohibited materials. ${ }^{111}$ 
In July 2014, Japan eased its autonomous sanctions following both countries' diplomatic talks and the launch of the Special Investigation Committee to inquire into cases of abduction of Japanese nationals. The government lifted the entry ban on North Korean nationals and allowed the entry of North Korean flag vessels for humanitarian reasons. ${ }^{112}$ Nevertheless, the restrictive measures were reinstated in February 2016, as a result of North Korea's fourth nuclear test and the ballistic missile launches on January 6 and February 7, 2016, respectively. ${ }^{113}$ Furthermore, the Japanese government introduced a prohibition on payment to individuals who have domiciles in North Korea and expanded the scope of targets subject to asset freeze measures. ${ }^{114}$ These unilateral measures were followed by the adoption of UN Security Council Resolution 2270 in March 2016, ${ }^{115}$ which was implemented through the FEFT Act.

Part of the non-UN restrictive measures that Japan took includes targeted sanctions against the specifically designated entities and individuals on the basis that they are involved in the development of weapons of mass destruction. While the UN's 1718 Sanctions Committee on North Korea designates the specific targets of the UN's sanctions, the Japanese government has its own list of targeted individuals and entities as part of the international measures taken among like-minded States. As of December 28, 2018, the list included 56 entities and 62 individuals, including many not on the UN's list. ${ }^{116}$

\section{Counterterrorism sanctions and due process concerns}

As described in Section II of this chapter, in 2014, the Japanese Diet adopted a piece of legislation to strengthen the domestic regulations on terrorist financing and give a fuller effect to the UN's 1267 sanctions regime and Security Council Resolution 1373. The initial domestic implementation measures to restrict terrorist financing relied primarily on the FEFT Act, ${ }^{117}$ which fell short of restricting domestic transactions among residents of Japan. ${ }^{118}$ The 2014 act was enacted in order to extend the coverage of asset freeze measures, which simultaneously augmented the role of the police organization in Japan to implement the UN's counterterrorism sanctions. ${ }^{119}$

Within the EU, the expansion of the UN's 1267 sanctions regime after the September 11 terrorist attack in New York City triggered a wide range of due process concerns. An asset freeze has a significant impact on the listed individual's right to property, as well as their privacy, reputation, and family rights. Given that no hearing is institutionalized before, or shortly after, the designation of specific targets, criticism has been leveled against the UN Security Council for failing to ensure the right to a fair hearing and the right to an effective remedy for those who are targeted by the Security Council and its sanctions committees. ${ }^{120} \mathrm{Kadi}$ and a series of litigations brought before the courts of the EU have highlighted deficiencies in the process at the UN when designating particular individuals and entities as global targets of asset freezes and travel bans. ${ }^{121}$ The proceedings and decisions of EU courts have incrementally facilitated improvements at the level of the UN with regard to its listing processes. ${ }^{122}$ 
In contrast to the attention given to due process concerns at the level of the EU, it is fair to say that due process issues have garnered little attention in the Japanese legal and political discourse concerning the implementation of counterterrorism sanctions. The varying degrees of attention given to the due process associated with sanctions are somewhat reflected in the narratives of the Member States that participated in the meetings of the UN Security Council. For instance, one of the procedural steps taken by the Security Council to ameliorate due process concerns was to establish, in 2009, the Office of the Ombudsperson for the 1267 Sanctions Committee, who was entrusted with receiving delisting requests from designated individuals and entities and assisting the Sanctions Committee's consideration of such requests in an independent and impartial manner. ${ }^{123}$ The establishment of the Ombudsperson's Office was welcomed by Member States, including Japan, but there remained differences in the narratives. At the Security Council meeting in May 2010, for instance, the Japanese delegation characterized the establishment of the Office of the Ombudsperson solely as a matter of ensuring the effectiveness of the 1267 sanctions regime and the credibility of the UN's list of targeted individuals and entities. ${ }^{124}$ In other words, the human rights narrative was missing from the statement. The Japanese delegation's narrative contrasted with the statement of the delegation of the EU during the same Security Council meeting, which described the UN's procedural development as an incremental effort to better ensure due process and respect for the fundamental rights of designated persons. ${ }^{125}$

The adoption of the 2014 Counter-Terrorism Act in Japan did not radically change the level of attention paid to the issue of due process associated with the UN's targeted sanctions. In theory, the act would impose significant restrictions on the rights of targeted individuals. Once designated under the act, individuals and entities would be prevented from withdrawing money from their bank accounts without permission. ${ }^{126}$ Likewise, the targeted persons would be restricted from borrowing money, securities, land, buildings, automobiles, and other controlled assets, or receiving a consideration for the sale or lease of their assets. ${ }^{127}$

Despite the material impact that the 2014 act would have on individuals' rights, the human rights compatibility of designation processes and asset freezes was rarely on the agenda during the deliberations of the Japanese Diet. When one of the members of the House of Councilors raised concerns over the compatibility of asset freezes and the designation processes with the constitutional right to property and due process, ${ }^{128}$ the government summarily dismissed such due process concerns. ${ }^{129}$ In the end, the Counter-Terrorism Act was adopted less than two months after the bill had been presented to the Japanese Diet without any substantive deliberations regarding due process.

That said, the 2014 Counter-Terrorism Act provides certain procedural safeguards, at least regarding the implementation of Resolution 1373. Under the 2014 act, the National Public Safety Commission can only designate individuals or entities for a specified period of time up to three years, and the list of targets ought to be renewed on a three-year basis. ${ }^{130}$ At least one of the criteria of designation is based on a criminal act; a person may be designated if the person is found to 
have committed, intended to commit, or assisted in a criminal act for the purpose of intimidating the general public and governments, and if there are sufficient reasons to believe that there is a clear danger that the person will commit, or assist in, criminal acts again in the future. ${ }^{131}$ Although criminal conviction is not required for the sake of designating particular persons, the Commission's decision is guided by the criminal act's definition. Furthermore, the National Public Safety Commission must conduct a hearing when listing a person subject to asset freezes. ${ }^{132} \mathrm{~A}$ designation can still be made without the hearing if it significantly jeopardizes the enforcement of asset freeze measures, yet the designation would be treated as provisional, and the Commission would have to conduct a hearing of opinions within 15 days from the date of the public notice of provisional designation. ${ }^{133}$

At the same time, these procedural safeguards do not alter the fact that there was little parliamentary debate on the impact of asset freeze measures on fundamental rights or whether the existing safeguards would be adequate. The requirement to conduct hearings is not applicable to the implementation of the 1267 sanctions committee though, inasmuch as designation is in the hands of the UN's sanctions committee, and Member States may have little discretion to decide whether to designate individuals. The relatively small amount of attention paid to due process concerns may be explained, at least in part, by the assumption of the Japanese Diet that relevant assets would rarely be present in the Japanese jurisdiction and that the 2014 act would, therefore, not be fully in use. At the same time, the presence of relevant assets in Japan and the full application of the 2014 act in the future may not necessarily trigger a greater debate over the question of due process. It would be particularly difficult to garner domestic political attention for issues of procedural safeguards in the absence of Kadi-type judicial proceedings to contest the validity of domestic implementation measures based on concerns about violations of fundamental rights.

\section{Conclusion}

Overall, economic sanctions have increased their strategic presence over the years in Japanese foreign and security policies. The series of legislative reforms of the FEFT Act best illustrates the changes in the role of economic sanctions in the wider Japanese political environment. Until July 2006, prior initiatives by the UN or other key political partners have guided the Japanese decisions to instigate economic sanctions, and, before the 2004 amendment, the FEFT Act did not specifically envisage the adoption of measures to safeguard Japan's own national security. Nevertheless, a series of missile and nuclear tests by North Korea, as well as the political stalemate on the matter of the abduction of Japanese nationals, paved the way for the more proactive use of economic sanctions.

The FEFT Act remains the primary medium through which the Japanese government gives effect to both UN and non-UN economic sanctions at the domestic level. At the same time, in the context of counterterrorism sanctions, the FEFT Act turned out to be inadequate in regulating the domestic transfer of funds involving 
residents in Japan. The Japanese Diet enacted a specific piece of legislation to implement the UN's 1267 sanctions regime and the measures under Security Council Resolution 1373 in 2014. The enactment of such a piece of legislation was made possible at the domestic level, not necessarily by the UN Security Council resolutions per se but by the nonbinding yet effective recommendations of the FATF.

Overall, the development of economic sanctions entails not only shifts in a country's foreign policies but also several critical alterations in its domestic legal frameworks. In Japan, such changes have augmented the powers of various executive bodies, including the police apparatus, in the context of implementing the UN's counterterrorism measures. Due in part to the assumption that the targeted individuals and entities might not reside in Japan, the act was readily adopted without sufficiently addressing the impact of the counterterrorism measures on the rights and interests of designated individuals and entities. This happened despite the history of court challenges in the EU and elsewhere against the implementation measures of the UN's 1267 sanctions regime. As demonstrated by the differences in the level of attention given to due process concerns, economic sanctions are applied in a highly fragmented process in which each country's laws and politics construct the effectiveness and critical assessment of economic sanctions.

\section{Notes}

1 See Chapter 6 of this book.

2 Martin Russell, "EU Sanctions: A Key Foreign and Security Policy Instrument," European Parliamentary Research Service, PE 621.870 (May 2018), pp. 3-4. As of February 2019, the EU Sanctions Map listed 25 non-UN sanctions, available at $<$ https:// sanctionsmap.eu/\#/main $>$ (accessed February 1, 2019).

3 See Section II.1 of this chapter.

4 See Machiko Kanetake, The UN Security Council and Domestic Actors: Distance in International Law (2018), pp. 99-117, 136-146 (Sections 6.3 and 7.3).

5 U.N. Doc. S/RES/661 (August 6, 1990).

6 Glenn D. Hook, Militarisation and Demilitarisation in Contemporary Japan (2003), p. 84.

7 See Daniel W. Drezner, "Bargaining, Enforcement, and Multilateral Sanctions: When Is Cooperation Counterproductive?” International Organization, Vol. 54 (2000), p. 87. On the first North Korean nuclear crisis in 1993 and 1994, see Masahiko Asada, "Arms Control Law in Crisis? A Study of the North Korean Nuclear Issue," Journal of Conflict and Security Law, Vol. 9 (2004), pp. 334-338.

8 U.N. Doc. S/25407 (March 12, 1993), Annex (Statement of DPRK Government); David Fischer, History of the International Atomic Energy Agency: The First Forty Years (1997), p. 290.

9 U.N. Doc. A/RES/48/14 (November 1, 1993).

10 Fisher, supra note 8, p. 290.

11 United Nations Act 1946, 9 and 10 Geo. 6, Chapter 45; United Nations Participation Act 1945, Public Law 79-264.

12 Foreign Exchange and Foreign Trade Act, Act No. 228 of December 1, 1949, last amended June 8, 2018 (effective April 1, 2019).

13 FEFT Act, Act No. 228 of December 1, 1949, Article 1 (as of December 1, 1949). 
14 Judgment of July 8, 1969, Tokyo District Court, Case No. 1969 (Gyo U) 30. See Hisashi Owada, "Japan," in Vera Gowlland-Debbas ed., National Implementation of United Nations Sanctions: A Comparative Study (2004), pp. 286-287; Chin Kim, "The CoCom Case," Journal of World Trade Law, Vol. 4 (1970), p. 604; Shinya Murase, "Trade Versus Security: The COCOM Regulations in Japan," Japanese Annual of International Law, Vol. 31 (1988), pp. 5-6.

15 Ian Anthony, "The Evolution of Dual-Use Technology Controls: A Historical Perspective," in Oliver Meier ed., Technology Transfers and Non-Proliferation: Between Control and Cooperation (2014), pp. 26-28.

16 Export Trade Control Order, Cabinet Order No. 378 of December 1, 1949, as amended in 1968, Article 1(6).

17 FEFT Act, Act No. 228 of December 1, 1949, as amended by Act No. 65 of December 18, 1979 (effective December 1, 1980), Articles 23(2)(iv) (capital transactions) and 25(ii) (service transactions).

18 Murase, supra note 14, p. 9.

19 FEFT Act, Act No. 228 of December 1, 1949, as amended by Act No. 65 of December 18, 1979 (effective December 1, 1980), Article 48.

20 Ibid., Article 1.

21 See "Submarined by Japan and Norway," New York Times (June 22, 1987), available at <www.nytimes.com/1987/06/22/opinion/submarined-by-japan-and-norway.html> (accessed February 1, 2019).

22 Tokyo District Court, Judgment, March 22, 1988, Case No wa-1547 (1987), Hanreijiho (Judicial Reports), No. 1271, p. 30, translation available in Japanese Annual of International Law, Vol. 31 (1988), pp. 206-211.

23 FEFT Act, Act No. 228 of December 1, 1949, as amended by Act No. 89 of September 11, 1987 (effective November 10, 1987), Article 48(1).

24 Ibid., Article 69-6.

25 FEFT Act, Act No. 228 of December 1, 1949, as amended by Act No. 1 of February 16, 2004 (effective February 26, 2004), Article 1.

26 Ibid., Article 10.

27 On the 2001 incident, see Atsuko Kanehara, "The Incident of an Unidentified Vessel in Japan's Exclusive Economic Zone," Japanese Annual of International Law, Vol. 45 (2002), p. 116.

28 FEFT Act, supra note 12, Article 16(1). Article 16(1) provides as follows: "The competent minister may ... impose the obligation to obtain permission for a payment or payment, etc. on a resident or non-resident who intends to make a payment from Japan to a foreign state or a resident who intends to make a payment, etc. to a non-resident when the competent minister deems necessary for the sincere fulfillment of obligations under treaties or other international agreements which Japan has signed or when he/ she deems particularly necessary to enable Japan to contribute to international efforts to achieve international peace, or when a cabinet decision set forth in Article 10, paragraph (1), has been made, except where the payment, etc. pertains to a transaction or act for which the obligation to obtain permission or approval is imposed from the same standpoint as the above."

29 Foreign Exchange Order, Cabinet Order No. 260 of October 11, 1980, last amended November 9, 2018 (effective January 9, 2019), Article 6(1).

30 FEFT Act, supra note 12, Article 16(1); FE Order, supra note 29, Article 6(1).

31 U.N. Doc. S/RES/1970 (February 26, 2011).

32 MOFA Public Notice No. 75 of 2011 (March 8, 2011).

33 METI Public Notice No. 34 of 2011 (March 8, 2011).

34 FEFT Act, supra note 12, Article 21(1). Article 21(1) provides as follows: "When the Minister of Finance finds that a resident or non-resident engaging in capital transactions ... without any restrictions will prevent Japan from sincerely fulfilling its obligations under treaties and other international agreements it has signed or from making its contribution to international efforts to achieve international peace, will make it difficult 
to achieve the purposes of this Act, or, when a cabinet decision set forth in Article 10, paragraph (1), has been made, he/she may impose the obligation to obtain permission to engage in said capital transactions on the resident or non-resident, pursuant to the provisions of Cabinet Order."

35 FEFT Act, supra note 12, Article 21(1); FE Order, supra note 29, Article 11(1).

36 FEFT Act, supra note 12, Article 24(1); FE Order, supra note 29, Article 15(1). Article 24(1) of the FEFT Act provides as follows: "When the Minister of Economy, Trade and Industry finds a resident engaging in specified capital transactions ... without any restrictions will prevent Japan from sincerely fulfilling its obligations under treaties and other international agreements it has signed or from making its contribution to international efforts to achieve international peace, will make it difficult to achieve the purposes of this Act, or when a cabinet decision set forth in Article 10, paragraph (1), has been made, he/she may impose the obligation to obtain permission to engage in the specified capital transactions on the person, pursuant to the provisions of Cabinet Order."

37 FEFT Act, supra note 12, Article 24(1); FE Order, supra note 29, Article 14. The pertinent transactions have been specified by the Public Notice issued by the METI: METI Public Notice No. 193 of 2003 (last amended by METI Public Notice No. 194 of 2017, August 16, 2017).

38 U.N. Doc. S/RES/2140 (February 26, 2014); UN Press Release SC/11636 (November 7, 2014).

39 MOFA Public Notice No. 394 of 2014 (December 17, 2014).

40 METI Public Notice No. 246 of 2014 (December 17, 2014) (amending METI Public Notice No. 193 of 2003).

41 U.N. Doc. S/RES/1718 (October 14, 2006).

42 Ibid., para. 8(c).

43 FEFT Act, supra note 12, Article 25(6); FE Order, supra note 29, Article 18(3); Ministry of Finance Public Notice No. 100 of 1998, March 30, 1998, as amended. Article 25(6) of the FEFT Act provides as follows: "When the competent minister finds that if service transactions between a resident and a non-resident . . . or transactions related to the buying and selling, leasing or donating of goods involving the movement of goods between foreign states . . . are carried out without any restrictions, it will cause a situation that prevents Japan from sincerely fulfilling obligations under the treaties and other international agreements it has signed or from making its contribution to international efforts for achieving international peace, which will make it difficult to achieve the purpose of this Act, or when a cabinet decision set forth in Article 10, paragraph (1), has been made, he/she may impose, pursuant to the provisions of Cabinet Order, on a resident who intends to carry out the service transactions, etc., the obligation to obtain permission for the implementation of the service transactions, etc."

44 FEFT Act, supra note 12, Articles 48(3), 52. Article 48(3) provides as follows: "the Minister of Economy, Trade and Industry may impose the obligation to obtain approval to the extent necessary to maintain equilibrium in the international balance of trade, achieve the sound development of foreign trade and the national economy, sincerely fulfill obligations under the treaties and other international agreements Japan has signed, allow Japan to contribute to international efforts to achieve international peace, or to implement a cabinet decision set forth in Article 10, paragraph (1), on a person who intends to export specific kinds of goods or to export goods to the specified regions or a person who intends to export goods through specified transactions pursuant to the provisions of Cabinet Order." Article 52 provides as follows: "For the purpose of achieving the sound development of foreign trade and the national economy, sincerely fulfilling obligations under the treaties and other international agreements Japan has signed, making Japan's contribution to international efforts for achieving international peace, or implementing a cabinet decision set forth in Article 10, paragraph (1), any person who intends to import goods may be obliged to obtain import approval pursuant to the provisions of Cabinet Order." 


\section{Machiko Kanetake}

45 FEFT Act, supra note 12, Article 48(1); Export Trade Control Order, Cabinet Order No. 378 of December 1, 1949 (last amended November 21, 2018; effective on September 1, 2019), Appended Table 1.

46 FEFT Act, supra note 12, Article 48(3).

47 Import Trade Control Order, Cabinet Order No. 414 of December 29, 1949 (last amended June 6, 2003).

48 Owada, supra note 14, p. 291.

49 U.N. Doc. S/RES/820 (April 17, 1993), para. 24.

50 See Owada, supra note 14, pp. 280-281; Immigration Control and Refugee Recognition Act, Cabinet Order No. 319 of October 4, 1951.

51 U.N. Doc. S/RES/1267 (October 15, 1999); U.N. Doc. S/RES/1989 (June 17, 2011); U.N. Doc. S/RES/2253 (December 17, 2015). For an overview of the 1267 sanctions regime, see Machiko Kanetake, "United Nations Security Council 1267 on Measures Against the Taliban, 15th October 1999 (UN Doc S/RES/1267 (1999))," OXIO 33 (April 1, 2016), in Oxford International Organizations (Oxford University Press, 2017).

52 U.N. Doc. S/RES/1989 (June 17, 2011).

53 U.N. Doc. S/RES/1988 (June 17, 2011).

54 U.N. Doc. S/RES/1373 (September 28, 2001).

55 See, with respect to the 1267 sanctions regime, e.g., U.N. Doc. S/RES/1390 (January 28, 2002), para. 2; U.N. Doc. S/RES/1989 (June 17, 2011), para. 1(a); U.N. Doc. S/RES/2161 (June 17, 2014), para. 1(a).

56 Act on Special Measures concerning the Freeze of Assets of International Terrorists and Other Measures Conducted by the Government Taking into Consideration United Nations Security Council Resolution 1267, etc., Act No. 124 of November 27, 2014 (effective October 5, 2015).

57 Financial Action Task Force, "Third Mutual Evaluation Report: Anti-Money Laundering and Combating the Financing of Terrorism, Japan," (October 17, 2008), available at <www.fatfgafi.org/media/fatf/documents/reports/mer/MER\%20Japan\%20full.pdf> (accessed February 1, 2019), para. 38.

58 FATF, ibid., p. 247.

592014 Counter-Terrorism Act, supra note 56, Article 3(1).

60 Ibid., Article 9(i).

61 Ibid., Article 9(ii).

62 Ibid., Article 9(iii).

63 Ibid., Article 15.

64 Ibid., Article 4(1)(i).

65 Cabinet Order to Determine Competent Ministers in the Foreign Exchange and Foreign Trade Control Act, Cabinet Order No. 259 of 1980, last amended July 14, 2017 (effective October 1, 2017).

66 U.N. Doc. S/RES/1970 (February 26, 2011), para. 9.

67 Import Trade Control Order, supra note 47, Article 3(1); METI Public Notice No. 36 of 2011 (March 8, 2011).

68 Public Announcement on the Items of Goods Subject to Import Quotas, the Places of Origin, or Places of Shipment of Goods Requiring Approval for Import, and Other Necessary Matters Concerning Import of Goods, the Ministry of International Trade and Industry Public Notice No. 170 of 1966, April 30, 1966, as amended.

69 FEFT Act, supra note 12, Article 24(1); FE Order, supra note 29, Article 15(1).

70 Cabinet Order No. 259 of 1980, supra note 65; FEFT Act, supra note 12, Article 16(1); FE Order, supra note 29, Article 6(1).

71 Ibid.

72 U.N. Doc. S/RES/2140 (February 26, 2014).

73 MOFA Public Notice No. 394 of 2014 (December 17, 2014). 
74 METI Public Notice No. 246 of 2014 (December 17, 2014). The public notice updated the list of specified capital transactions subject to permission: METI Public Notice No. 193 of 2003 (May 31, 2003).

75 METI Public Notice No. 245 of 2014 (December 17, 2014). The public notice updated the list of payments subject to permission; METI Public Notice No. 229 of 2009 (July 7, 2009). Likewise, the MOF updated the list of payments subject to permission: MOF Public Notice No. 97 of 1998 (March 30, 1998) (last updated July 29, 2016).

76 Police Act, Act No. 162 of June 8, 1954 (last amended December 2, 2016; effective June 1, 2017), Articles 4-16.

772014 Counter-Terrorism Act, supra note 56, Article 3.

782014 Counter-Terrorism Act, supra note 56, Article 4.

79 National Public Safety Commission Public Notice No. 36 of 2015 (October 30, 2015).

80 U.N. Doc. S/RES/1269 (October 19, 1999), para. 1.

81 U.N. Doc. S/RES/1373 (September 28, 2001), para. 1(b).

82 U.N. Doc. S/RES/2253 (December 17, 2015), para. 12.

83 E.g., U.N. Doc. S/RES/1735 (December 22, 2006), preamble para. 10; U.N. Doc. S/RES/2253 (December 17, 2015), paras. 44, 58.

84 E.g., Sixth Report of the Analytical Support and Sanctions Monitoring Team Appointed Pursuant to Security Council Resolutions 1526 (2004) and 1617 (2005) Concerning Al Qaeda and the Taliban and Associated Individuals and Entities, U.N. Doc. S/2007/132 (March 8, 2007), para. 36, box 1.

85 FEFT Act, supra note 12, Article 69-7(1)(iv). Calculated as USD $1=$ JPY 110.

86 Ibid.

87 FEFT Act, Act No. 228 of 1 December 1949, as amended by Act No. 38 of May 24, 2017 (effective October 1, 2017), Article 69-7.

88 Ibid., Article 70(1)(iii).

89 Ibid., Article 72(1)(iii).

90 Ibid., Article 53(2).

91 FEFT Act, Act No. 228 of 1 December 1949, as amended by Act No. 38 of May 24, 2017 (effective October 1, 2017), Article 53(2).

92 The summary of major cases in Japan can be found on the website of the Center for

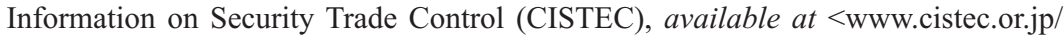
export/ihanjirei/index.html $>$ (accessed September 1, 2018).

93 Ibid.

94 U.N. Doc. S/RES/1718 (October 14, 2006).

95 For the details of the North Korean sanctions, see Chapter 9 of this book.

96 Cabinet Notice No. 3 of 2006 (July 5, 2006); Act on Special Measures concerning Prohibition of Entry of Specified Ships into Ports, Act No. 125 of June 18, 2004, Article 3(1).

97 U.N. Doc. S/RES/1695 (July 15, 2006).

98 U.N. Doc. S/RES/1695 (July 15, 2006), para. 4.

99 Measures to Prevent the Transfer of Assets Concerning the North Korean Missiles or WMD Programs under the FEFT Act (September 19, 2006), available at $<$ www. mofa.go.jp/mofaj/area/n_korea/abd/shikin.html > (accessed February 1, 2019).

100 Cabinet Notice No. 4 of 2006 (October 13, 2006); Act on Special Measures concerning Prohibition of Entry of Specified Ships into Ports, Act No. 125 of June 18, 2004, Article 3(3).

101 METI Public Notice No. 308 of 2006 (October 13, 2006).

102 METI Public Notice No. 311 of 2006 (October 13, 2006).

103 METI Public Notice No. 310 of 2006 (October 13, 2006). 


\section{Machiko Kanetake}

104 Cabinet Decision of October 13, 2006.

105 Export Trade Control Order, Cabinet Order No. 378 of December 1, 1949, as amended by Cabinet Order No. 160 of June 16, 2009 (effective on June 18, 2009); FEFT Act, supra note 12, Article 48(3).

106 METI, "Notice" (June 16, 2009), available at <www.meti.go.jp/policy/external economy/trade_control/01_seido/04_seisai/downloadNK/20090616oshirase.pdf $>$ (accessed February 1, 2019).

107 U.N. Doc. S/RES/1718 (October 14, 2006), para. 8(a); U.N. Doc. S/RES/1874 (June 12, 2009).

108 Act on Special Measures concerning Cargo Inspections, etc., Conducted by the Government Taking into Consideration United Nations Security Council Resolution 1874, etc., Act No. 43 of June 4, 2010 (effective July 4, 2010).

109 U.N. Doc. S/RES/1874 (June 12, 2009), para. 12.

110 Act on Special Measures concerning Cargo Inspections, etc., supra note 108, Article $8(1)$.

111 Ibid., Article 3(2).

112 "Partial Lifting of Japan's Measures Against the DPRK Based on Japan-DPRK Agreement in May 2014," (July 4, 2014), available at <www.kantei.go.jp/jp/tyoukanpress/ 201407/_icsFiles/afieldfile/2014/07/04/20140704siryou2_1.pdf $>$ (accessed February 1, 2019) (in Japanese).

113 "Measures Taken by the Government of Japan Against North Korea," MOFA (February 10, 2016), available at <www.mofa.go.jp/a_o/na/kp/page4e_000377.html> (accessed February 1, 2019).

114 Ibid.

115 U.N. Doc. S/RES/2270 (March 2, 2016).

116 The list is available on the METI website at <www.mof.go.jp/international_policy/ gaitame_kawase/gaitame/economic_sanctions/list.html>.

117 See, e.g., "Japan: Report to the Counter-Terrorism Committee Pursuant to Paragraph 6 of Security Council Resolution 1373 (2001) of September 28, 2001," U.N. Doc. S/2001/1306 (December 27, 2001), p. 8.

118 See Section II.1(2) of this chapter.

119 See Section II.2 of this chapter.

120 Kanetake, supra note 4, pp. 101-105 (Section 6.3.2).

121 Ibid., pp. 136-146, 160-164, and 181-218 (chapters 7.3 and 8.3.1, and Annexes I and II).

122 Ibid., chapter 8.

123 U.N. Doc. S/RES/1904 (December 17, 2009), paras. 20-21, Annex II.

124 U.N. Doc. S/PV.6310 (May 11, 2010), p. 14 (Mr. Okuda of Japan).

125 Ibid., p. 27 (Mr. Serrano on behalf of the EU).

1262014 Counter-Terrorism Act, supra note 56, Article 9.

127 Ibid.

128 Question No. 84 of the 187th Diet (Extraordinary Session), from Taro Yamamoto (November 18, 2014), available at <www.sangiin.go.jp/japanese/johol/kousei/ syuisyo/187/meisai $/ \mathrm{m} 187084 . \mathrm{htm}>$ (accessed February 1, 2019) (in Japanese).

129 Written Answer No. 84 of the 187th Diet (November 25, 2014), available at <www. sangiin.go.jp/japanese/joho1/kousei/syuisyo/187/meisai/m187084.htm> (accessed February 1, 2019) (in Japanese).

130 Ibid., Articles 4(1) and 6(1).

131 Ibid., Article 4(1)(ii)(a).

132 Ibid., Article 4(4).

133 Ibid., Articles 8(3) and (5). 


\section{Part III}

Case studies 


\section{North Korea \\ Design, implementation, and evasion}

Andrea Berger

\section{Introduction}

In his 2018 New Year's Day address, North Korea's leader Kim Jong Un hailed an array of "signal victories" made by the country the preceding year, including "perfecting the national nuclear forces." During 2017, Pyongyang detonated what it claimed to be a thermonuclear device and repeatedly tested intercontinental ballistic missiles designed to carry that payload. "The whole of [the US] mainland is within the range of our nuclear strike and the nuclear button is on my office desk all the time," Kim noted, adding that those feats were proudly accomplished in the face of sanctions applied with unprecedented vigor by the US and its allies. ${ }^{2}$ Indeed, North Korea's provocations were met with sometimes unexpectedly swift, regular, and substantive responses by the United Nations Security Council (UNSC). The Council's members, particularly the United States, were eager to show Pyongyang that its actions have consequences, and the only way out is through complete disarmament.

The United Nations now oversees a sanctions regime more complex than any it has previously adopted, and its most complicated measures are among its most recent. Following North Korea's fourth nuclear test in January 2016, the UN added significant new provisions to a modest set of restrictions on definitively proliferation-connected activity. These additions were much broader and more ambitious, ranging from bans on major North Korean export commodities, to a tapestry of shipping constraints, to restrictions on much of North Korea's access to the international financial system.

Partly as a result of this complexity, implementation of these sanctions resolutions, whether old or new, remains slow and patchy. In some parts of the globe, implementation is undermined by gaps in awareness or understanding, by competing priorities, or by a lack of capacity and resources. Elsewhere, including in traditional North Korean partner countries, sanctions are being actively ignored or even obstructed. Nevertheless, the broader implementation picture appears to be improving. Unilateral sanctions and outreach by countries such as the US, South Korea, and Japan, or multilateral restrictions such as those imposed by the European Union, are helping to compel countries to pay greater attention to their obligations. National sanctions and corresponding guidance have also shone a 
brighter spotlight on Pyongyang's evasive practices, which United Nations monitors indicate are increasing in "scale, scope, and sophistication." So while state implementation may be advancing, North Korea's tactics are undercutting those gains and making it disproportionately difficult for implementers to detect, prevent, or respond to illicit North Korean activity overseas.

Now having celebrated its eleventh birthday, the sanctions regime on North Korea is at a crossroads. North Korea remains nuclear armed and repeatedly asserts that it will only consider renouncing its weapons once a fundamental transformation of its security environment occurs. ${ }^{4}$ Nuclear weapons are framed as central to the regime's survival and domestic legitimacy. What role therefore should sanctions play if their initial goal of complete North Korean disarmament becomes unattainable? Will countries stay attentive to North Korea sanctions implementation requirements indefinitely? Any fatigue or easing of sanctions implementation would reduce the practical impact of on-paper measures. While notable progress has recently been made in building greater global buy-in to the importance of rigorously implementing UN sanctions, that agreement is fragile.

At the time of writing, efforts to address the North Korean nuclear issue through dialogue have also been elevated to the highest levels, with frequent summit meetings taking place between Kim Jong Un and foreign leaders. Whether these initiatives will yield progress on rolling back North Korean nuclear capabilities remains to be seen, though the prospect that the longstanding goal of sanctions may be rapidly discarded in favor of something that allows the White House to declare victory and move on from the North Korea issue cannot be discounted. Each day's developments seem to upend yesterday's clarity, and the future of the sanctions regime is caught in this turbulence.

\section{Crafting United Nations sanctions on North Korea}

On a Monday morning in October 2006, North Korea became the eighth country in history to test a nuclear device. As many feared, the development "profoundly change[d] the politics of Asia." ${ }^{\circ}$ Fewer appreciated at the time how significant its implications would be for the use of sanctions as a foreign policy tool.

\section{The first United Nations restrictions}

North Korea's first nuclear test prompted the UN Security Council to act. It adopted Resolution 1718 (2006), demanding that North Korea suspend all nuclear and missile activities and rejoin the Treaty on the Nonproliferation of Nuclear Weapons (NPT) as a nonnuclear weapons state. ${ }^{6}$ The resolution also imposed a set of modest sanctions on Pyongyang. It banned the sale of luxury goods to North Korea, in hopes of removing some of the comforts of the country's elite; trade in major conventional weapons, ballistic missiles, and related goods and services, to restrict revenue going to North Korea's military industrial complex and to address Pyongyang's active sale of weapons-related technology overseas; and, trade in dual-use goods that North Korea might need for its prohibited activities. 
In addition, the Council adopted a travel ban and assets freeze and added a short list of sanctioned parties to it. ${ }^{7}$

At the time it was apparent that UNSC members believed Pyongyang had taken a step across the nuclear threshold but not an irreversible leap. Its cost-benefit calculation over its nuclear weapons program could still be affected by a limited set of economic sanctions. Common wisdom was that North Korea would bargain away its prohibited activities for the right price - a view North Korea itself fueled by insisting repeatedly that it was open to denuclearization if an appropriate agreement could be reached through negotiations such as the Six Party Talks. ${ }^{8}$

Only two months later, the Council adopted sanctions on Iran for concerns over its nuclear program, which included some of the features of the measures pursued against North Korea, namely an asset freeze and ban on trade in certain nuclear-related goods. ${ }^{9}$ A partial arms embargo followed shortly thereafter. ${ }^{10}$ In swift succession, the UNSC had adopted sanctions to respond to a country's brazen crossing of the nuclear threshold (North Korea) and to deter another from pursuing the same path (Iran). Yet it would take a decade for the Council's permanent members to accept that compelling a country - especially one like North Korea - to forego nuclear weapons it had already built would require a much more robust multilateral sanctions package than the one they had initially conceived, and more than the one adopted for a country that had not yet decided to join the nuclear weapons club.

\section{A decade of little movement}

Between 2006 and 2015, the UN sanctions regime against North Korea remained modest in scale and scope. It saw limited expansion only when North Korea conducted further nuclear tests in 2009 and in 2013; other developments were insufficient to convince the Security Council's greatest sanctions sceptics - China and Russia - that new measures were warranted. Consequently, for the decade after the first sanctions resolution on North Korea, the sanctions regime remained firmly anchored to restrictions on proliferation-connected activity. Member States were directed and authorized to act when they had grounds to believe a particular person, entity, asset, vessel, or good was linked to weapons proliferation, though for many proving this link was (sometimes unpalatably) challenging and time consuming. ${ }^{11}$

As was the case in 2006, cycles of provocation and engagement kept hopes afloat that a carefully calibrated mixture of carrots and sticks could resolve the nuclear issue on the Korean Peninsula. North Korea participated in multilateral dialogue through late 2008, sporadically agreeing to limited transparency and confidence-building measures. Talks broke down over the issue of inspection access to North Korean sites and eventually ceased when Pyongyang conducted a satellite launch and nuclear test in 2009. ${ }^{12}$

Hopes of progress resurfaced in early 2012, with the ascension of North Korea's new, Western-educated leader Kim Jong Un. The United States and North Korea held bilateral, exploratory discussions that culminated in the so-called "Leap Day 
Deal" of February 29, 2012. According to Washington, North Korea had agreed to a moratorium on nuclear tests and nuclear activities at its main complex, Yongbyon, along with a freeze on long-range missile launches, in exchange for certain types of aid. ${ }^{13}$ The agreement again swiftly collapsed over disagreements about what Pyongyang had agreed to. Washington asserted that "peaceful" satellite launches were within the scope of the deal. Pyongyang disagreed and attempted such a launch only a few weeks later. The entire debacle was an embarrassment not soon to be forgotten in Western policy circles and put the United States on a course toward a more pressure-oriented approach to the North Korean nuclear issue.

\section{A shift in approach}

Another significant shift in thinking over sanctions appears to have taken place in late 2014, when North Korea hacked the multinational firm Sony Pictures. In response, US President Barack Obama signed an Executive Order that created a broad legal authority to unilaterally sanction entities or individuals affiliated with the North Korean government or anyone who has assisted them. ${ }^{14}$ This was a notably lower burden of proof than the US Treasury previously required; the anchor in proliferation-connected activity had been raised.

Two considerations were likely influential in solidifying this change in US thinking. The first involves lessons learnt from the Iran sanctions experience. In 2013-2014, there was clear progress in nuclear negotiations with Tehran, which Washington believed had been made possible by sanctions imposed on Iran's export commodities, on its shipping activities, and on its access to the international financial system. Nuclear policy experts and sanctions specialists alike continue to point to the Iranian case as a sanctions success story. ${ }^{15}$

The second concerned assessments of North Korea's nuclear strategy. Whereas in 2006 many experts understandably believed that North Korea was using its nuclear program as a bargaining chip and was not yet fully committed to nuclear armament, few seemed to believe this was the case by 2015. Kim Jong Un did not show more flexibility than his predecessors. Indeed, he appeared determined to advance the nuclear and missile programs to promote his leadership credentials at home. Among other things, he had restarted the disabled 5-Megawatt reactor at Yongbyon ${ }^{16}$ and enshrined North Korea's nuclear weapons state status in its

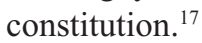

It is therefore not surprising that the Obama Administration felt that sanctions on North Korea would need to expand considerably if they were to have any hope of changing the calculations of such a determined proliferator. This view seems to have underpinned the raft of new sanctions that Washington proposed to its Security Council counterparts, specifically China, in the wake of North Korea's fourth nuclear test on January 6, 2016. Suggested measures mirrored areas targeted in the Iran sanctions regime: North Korea's major export commodities, namely coal and certain minerals, as well as its access to the international financial system and to maritime commerce. 
However, a major difference between the US approach to Iran and North Korea sanctions was where those sanctions were pursued. In the Iran case, they were adopted as part of autonomous sanctions regimes in consultation with like-minded partners (including the EU, which was an important source of trade and finance for Iran), or they were negotiated in informal bilateral agreements with relevant countries. For example, caps on the import of Iranian energy projects were agreed bilaterally between the US and Iran's major customers - including China, India, and South Africa. ${ }^{18}$

In the North Korea case, the option to pursue major measures outside the UNSC was neither feasible nor attractive. The main sources of trade and finance for North Korea were not US like-minded partners; bringing them onside would undoubtedly help with the global push to strengthen sanctions but would not in itself result in a biting impact on North Korea. Rather, to create pain on the country through sanctions, the US would need to compel North Korea's major trading partners - China and Russia - as well as a suite of relevant countries further afield $^{19}$, to take action to curb previously legitimate business with North Korea. If China and Russia would sign on to proposed measures, then the Security Council would be in a political position to impose binding obligations on all UN Member States. North Korean partners in Africa, the Middle East, and Southeast Asia would be covered too.

When US officials approached China about a new sanctions resolution in the immediate wake of North Korea's fourth nuclear test, they expected substantial pushback. Washington was asking for sanctions on major North Korean exports or financial flows, whose main markets or conduits were in China. Little progress was made in securing Beijing's agreement over a new resolution for weeks until North Korea launched a satellite into orbit using rocket technology in February $2016 .{ }^{20}$ The proposed text that had seen little movement for weeks was suddenly rushed through negotiations between Washington and Beijing. Russia was only given sight of the text later and issued several new demands (including exemptions for specific joint trade zones) that resulted in delays to the resolution's adoption.

Resolution 2270 was ultimately passed by the Council on March 2, 2016, and it represented a major turning point for the multilateral sanctions regime on North Korea. Measures approved included an expanded arms embargo, mandatory inspections of all goods going to or from North Korea or brokered by North Korea, new sanctions on DPRK vessels or aircraft, prohibitions on North Korean banks having branches, offices, or correspondent bank accounts overseas, prohibitions on new foreign banking presences in North Korea, and sectoral sanctions on the purchase of coal and certain minerals from North Korea. The latter was, controversially, subject to major carveouts for goods that were for undefined "livelihood" purposes, which China interpreted extremely broadly in practice. ${ }^{21}$

The US continued to justify the broader sanctions instigated by citing a link to proliferation, though the connection was undoubtedly thinner than for earlier sanctions specifically targeting the trade in prohibited programs or the actors who engage in them: "These sanctions make it much harder for the DPRK to raise 
funds, import technology, and acquire the know-how to continue its illicit nuclear and ballistic missile programs," according to the State Department. ${ }^{22}$ Sectoral sanctions and financial measures were explained using a particular logic: North Korea's governance system means that resources could be easily diverted to priority programs, and the top national priority was nuclear weapons. In other words, money made by North Korea in any way could be proliferation finance and should therefore be considered a potential target for sanctions. ${ }^{23}$

By allowing this line of reasoning to be introduced as a feature of North Korea sanctions design, China and Russia opened the door to an unprecedented set of expanded or new measures. All North Korean export commodities would be fair game. The means to facilitate North Korean trade - financial transactions, as well as maritime, overland, and air trade - would be too. As a result, in the two years since the adoption of Resolution 2270, the US (in concert with its allies) pushed for sanctions to be expanded in precisely this fashion, and by many accounts it has been repeatedly surprised by its success in securing Chinese and Russian agreement. $^{24}$

\section{The multilateral sanctions regime today}

Four resolutions adding major new sanctions on North Korea followed the watershed that was Resolution 2270. Two have come on the heels of North Korean nuclear tests in September 2016 and September 2017 - the traditional antecedent event for UNSC action. The other two, however, were the outcome of deliberations over how to respond to North Korea's intercontinental ballistic missile testing program, which saw rapid development during 2017. The relevant resolutions therefore represent the first occasions on which the sanctions regime was expanded because of a provocation other than a nuclear test.

Together, these Security Council decisions have dramatically altered the contours of the sanctions regime on North Korea. With each new provocation by Pyongyang, the US found it possible to successfully insist upon upgrades or additions to existing commodity bans, tighter restrictions on shipping or finance, or new constraints on North Korean corporate networks, diplomats, and migrant laborers. Bans on North Korea's major export, commodities and migrant labor have followed a particular pattern: they are often introduced as a partial ban or one subject to carveouts and later upgraded to a full prohibition. Restrictions on coal, for example, initially included the renowned "livelihood" exemption. ${ }^{25}$ That carveout was scrapped at the next opportunity and replaced by an elaborate system of annual caps on aggregate Member State coal imports from North Korea and an attendant reporting requirement. ${ }^{26}$ That system was, in turn, later upgraded in Resolution 2371 of August 2017, to a full ban on coal imports from North Korea. ${ }^{27}$ Certain other export commodities, such as seafood and textiles, were banned outright from their first appearance in the sanctions regime.

The US also used the growing number of political opportunities to amend the sanctions regime to address emerging implementation challenges. The newfound complexity of UN sanctions on North Korea created difficulties, either unforeseen 
or not fully appreciated at the time of a resolution's drafting, for Member States seeking to operationalize their sanctions obligations. Numerous provisions tweaking or clarifying previous measures were therefore introduced to give better direction to Member States as to how they would be expected to interpret or implement particular requirements. ${ }^{28}$

One of the more unusual measures now included within the sanctions regime on North Korea relates to caps on the sale of refined petroleum products and crude oil to North Korea. Until this sanction was added in December 2017, the Security Council had focused almost exclusively on curbing North Korean exports; imports were only targeted where they might be directly in service of Pyongyang's military programs. The United States made the argument that "oil is the lifeblood of North Korea's efforts to build and deliver a nuclear weapon." 29 Yet the civilian application of the energy products banned is also obvious, and the fact that China agreed to extend sectoral sanctions to import commodities after firmly resisting the proposed change is therefore somewhat surprising.

Yet arguably the most important design feature of the sanctions currently in force is how they interact. The complicated financial, transport, commodity, diplomatic, and network restrictions, as well as the raft of designations on entities, individuals, and ships, has created an intricate net that could, in principle, catch almost any North Korean-linked business. When looking in detail at any North Korean transaction, it is likely that at least one of the parties, brokers, commodities, logistical or financial pathways, or facilitation methods will run afoul of sanctions.$^{30}$ As such, the practical effect of the sum of the sanctions adopted is more substantial than a glance at its component parts would suggest.

Monitoring challenges associated with this expansive set of sanctions are sizeable. In 2009, the Security Council established a small, seven-member Panel of Experts to monitor compliance with the sanctions regime on North Korea and to investigate and document potential breaches in hard-hitting annual reports. While an eighth member was added several years later, the panel has not grown in tandem with the sanctions regime, not least because expanding its membership would also increase the difficulties of getting consensus agreement on findings among panel members. While the group's reports remain the go-to source of information on the state of sanctions implementation, monitoring capacity is likely to remain an area requiring attention in the coming years, should the sanctions regime retain its broad coverage.

\section{Autonomous sanctions regimes}

UNSC sanctions on North Korea do not exist in isolation. Alongside them are restrictions adopted by individual countries - including the United States, South Korea, Japan, Canada, and Australia - as well as the European Union. Sanctions adopted by these jurisdictions do not create binding obligations on other states in the way that UNSC resolutions do. Rather, they highlight a broader range of individuals and entities facilitating prohibited activity with North Korea, shape the behavior of private sector actors wanting to maintain business relations with the 
jurisdiction imposing sanctions, and create leverage in high-level bilateral discussions between the imposing country and third countries.

\section{The United States}

The US application of unilateral sanctions on North Korea demonstrates all three approaches. Washington is no newcomer to designing restrictions on Pyongyang in reaction to its destabilizing behavior, having imposed them on North Korea since the Korean War. However, the bulk of US autonomous sanctions on North Korea today were adopted in response to the country's nuclear and missile programs. As with the UN regime's scope, until early 2015 the US measures remained largely focused on designating individuals and entities involved in military activities. The majority of those designated by the US were also North Korean, rather than their customers or facilitators, and the direct, disruptive effect of US measures was therefore minimal. The United States has little direct interaction with North Korea, and North Korean parties covered by assets freezes or travel bans are unlikely to have had identifiable interests within reach of the US Treasury.

As outlined earlier, the Obama Administration's 2015 Executive Order widened the legal authorities for sanctions, and the Treasury became more active against third country facilitators. While unilateral sanctioning gained steam in the late days of the Obama Administration, the broader authorities introduced after the Sony Pictures hack went mostly unused, and the sanctions list on North Korea remained modestly sized. ${ }^{31}$

President Donald Trump mandated a step change in the type and number of restrictions imposed by Washington. The new administration's "maximum pressure" campaign has involved much more aggressively pursuing sanctions as means of imposing costs on North Korea and all who do business with it. In this respect, it has used its unilateral sanctions authorities to augment UN activity in several ways. First, it has used the process of designating individuals, entities, and vessels linked to North Korea as a way to put evidence of their activity into the public space, either when other countries on the Security Council have resisted sanctioning them or as a prelude to a push to have them sanctioned by the UN. ${ }^{32}$ This tactic makes it politically difficult for Security Council members - especially countries like China wanting to avoid a reputation for being lax on North Korean illicit activity - to oppose a particular designation.

Second, the US has used Treasury designations and penalties imposed by the Department of Justice to compel parts of the private sector, especially the global financial sector, to disengage with North Korean-linked business communities. During the Trump Administration, the US Treasury has been a conveyor belt of new North Korea designations, with a fresh action has been announced almost monthly. ${ }^{33}$ Treasury's newfound eagerness to take aim at private sector facilitators of North Korean trade and finance, including in third countries, has frightened some. In June 2017, the Treasury said it was issuing a proposed rule to designate China's Bank of Dandong a "primary money laundering concern," claiming that the bank served as a conduit for North Korean financial access to the United 
States..$^{34}$ In November, it made that rule final, cutting the Bank of Dandong from the US market..$^{35}$ The Treasury's actions sparked concern among some financial institutions that the US would aggressively pursue penalties against those found to be engaging in North Korean business and would in particular go after additional banks in China (which other foreign banks might rely upon for corresponding banking services). Adding to their nervousness, in August the US Department of Justice announced it was seeking civil asset forfeitures from several companies in Singapore and China relating to their dealings with North Korea, and the US Treasury sanctioned firms in China and Russia. ${ }^{36}$ It is unclear whether these actions have shifted banking practices within Chinese financial institutions or private companies - their most important audience.

Efforts to use unilateral sanctions to influence private sector behavior have extended beyond financial institutions. Impacting the activities of shipping companies, particularly in North Korea, has also been a high priority for Washington. Nowhere is this more evident than in the fact that the Treasury's Office of Foreign Assets Control (OFAC) had its advisory on North Korean shipping activity translated into and published in Mandarin. ${ }^{37}$

In sum, since Trump came into the White House and outlined a "maximum pressure" policy toward North Korea, there have been ten separate OFAC actions with new North Korea designations, one new Executive Order, a sanctions advisory, and several new congressional sanctions bills covering North Korea. The message being sent to the private sector, including in foreign countries, is clear and strong: you can do business with North Korea or with the United States but not both. As a message, it was also a familiar one - the US made the same argument about Iran.

In fact, the US has sought to extend the same threat to countries dealing with North Korea. In September 2017, the President stated that "The United States is considering ... stopping all trade with any country doing business with North Korea." ${ }^{38}$ Though implausible, especially given the value of Chinese trade to the United States, the comment did reflect a deeper change in thinking by the Trump Administration. Washington seems more willing than ever to raise the North Korea issue to the top of the bilateral agenda in its discussions with foreign countries, subordinating issues previously atop the list. Sudan discovered this in mid-2017, when the Trump Administration injected the North Korea issue into the conversation over whether sanctions on Sudan should be lifted. Restrictions on Khartoum were eventually relaxed but only after Sudan pledged to cut military ties with North Korea. In August 2017, the US cut or delayed nearly $\$ 300$ million in aid to Egypt partly over concerns that the country had enduring military ties to North Korea. Several weeks later, Egyptian officials publicly renounced those ties, though whether they have upheld this commitment is unclear. ${ }^{39}$

Similarly pointed discussions are being had by the United States with countries around the world. In some cases, unilateral sanctions on the country's companies, the withholding of benefits to the government, or threats of such sanctions, have sharpened the choices of decision makers in those countries who may not have previously ascribed the North Korea issue priority. The US approach is a complex 
diplomatic endeavor; sanctions policy becomes not only about changing the costbenefit calculation on of Pyongyang but also of dozens of countries who deal with it. Though it risks blowback on the United States if poorly calibrated and executed, the strategy has already yielded some fruit. Certain gaps in global implementation of UN sanctions have started to close, and several countries that previously ignored or deprioritized North Korea sanctions enforcement have cooperated, as the Egypt and Sudan cases illustrate. The more aggressive approach taken toward DPRK sanctions implementation since 2016 by the Obama and Trump White Houses have helped bring about these changes.

\section{Promoting alignment with like-minded countries}

One of the risks associated with an effort by the US to rapidly expand its unilateral authorities and the sanctions imposed under them is that in doing so, the US autonomous sanctions program falls significantly out of alignment with those of other allies. Washington traditionally seeks to promote such alignment through like-minded working groups on North Korea sanctions and through regular consultations. These interactions have led to some designations adopted by the US being mirrored by other countries; South Korea, for instance, has on many occasions incorporated US Treasury designations into its own sanctions list. ${ }^{40}$ The $\mathrm{EU}$, in close consultation with the US, often seeks to go beyond UN requirements when expanding its restrictive measures against North Korea. It sanctions a larger list of individuals and entities ${ }^{41}$ and periodically adopts commodity bans in advance of such prohibitions becoming UN obligations. ${ }^{42}$

US President Donald Trump's Executive Order of September 2017 seems to have been a largely symbolic effort to highlight alignment between the US sanctions regime and those of others. Several measures outlined in the order - such as that prohibiting vessels or aircraft that have called in ports in North Korea from entering a US port within the subsequent 180 days - would have little additional practical effect. ${ }^{43}$ Very few vessels or aircraft that make such trips to North Korea are likely to be looking to call at a port in the United States. Rather, this restriction mirrors one in place in ally sanctions regimes. ${ }^{44}$ In March 2016, Seoul barred vessels that had visited North Korea from visiting South Korean ports within the 180 days after leaving the North. ${ }^{45}$ The motivation for this measure was that in the preceding year, "a total of 66 North Korean ships under third party's flag entered South Korea over 104 times and mainly transported steel and miscellaneous items." ${ }^{16}$ The Park Geun-hye government later doubled the 180-day restriction. ${ }^{47}$ It is unclear whether the alignment with allied sanctions regimes that is reflected in the September Executive Order was conceived of in Washington or requested by friendly capitals.

Autonomous sanctions regimes have been influential in shaping the design and implementation of sanctions introduced at the UN level. Measures adopted by the US have often served as a preview for resolutions to come in New York. Washington's approach to autonomous restrictions has also sharpened the choices of public- and private-sector implementers worldwide, dramatically 
increasing the costs and risks of ignoring the UN sanctions regime. Unilateral restrictions have also been used as a mechanism to demonstrate and ensure greater policy coordination between the US and its allies on the use of sanctions toward North Korea.

\section{The implementation of sanctions on North Korea}

The UN sanctions regime on North Korea, and the autonomous sanctions regimes that interact with it, are a patchwork. Individual pieces have been sewn on opportunistically when North Korean provocations create political space for such action in the UNSC or in domestic political contexts. Implementation of UN sanctions involves a similar compilation of incongruous approaches and actions by Member States, only with many more holes. State implementation has been generally poor from the birth of the sanctions regime. A survey of the implementation picture conducted by this author previously concluded that "not a single sanctions measure enjoys robust, global implementation and enforcement." ${ }^{\text {" }}$ This assessment remains accurate today.

Gaps in state implementation exist for several reasons. In some cases, countries and the various bureaucratic actors that compose them remain ignorant of the precise obligations created by UNSC resolutions on North Korea. It is not uncommon to find countries with small New York missions and only one foreign ministry desk officer covering all UNSC developments, who are unaware of many of the nuances of the North Korea sanctions regime and their practical implications. Lack of awareness often collides with the fact that many countries have a long list of higher priorities that deplete the oxygen needed to fully consider the North Korea issue.

Elsewhere, gaps in implementation can be better explained by a dearth of resources necessary to translate $\mathrm{UN}$ obligations into national law and practice. One example of countries in this category are those offering flags of convenience. These (often small) nations are now required to ensure they deregister vessels that are owned, controlled, or operated by North Korea or have engaged in activities prohibited by the resolutions - a task which sometimes requires complex due diligence checks on a vessel and its owners and managers.

These states and many others have become aware that as the UN regime has grown more complex, so too has the task of understanding and complying with its provisions. Requisite legal or regulatory reform is often onerous. Entirely new interagency coordination, intelligence collection, or cross-border information sharing processes may be needed. These requirements are especially daunting when considered in the context of North Korean evasive activity; identifying, stopping, and prosecuting suspected North Korean illicit activity on one's territory is no simple affair in an age of sophisticated North Korean circumvention practices. Singapore came to appreciate this in 2017, when its legal case against a local firm assisting North Korean shipping networks fell apart because of an inappropriately drafted regulation that failed to take account of newer UN resolutions and of North Korea's well-established obfuscation methods. ${ }^{49}$ 
The sanctions regime's key proponents seem to finally appreciate the magnitude of what they are asking countries around the world to do in service of the North Korea sanctions regime. Effective, global implementation of the measures adopted in the UNSC will require carefully considered, systematic, and therefore burdensome change at a national level. Similarly because the most recent sanctions seek to cut North Korea's logistical, financial, and diplomatic connectivity to the wider international community, to deliver their intended impact these changes must be implemented by many countries worldwide, not only by North Korea's largest trading partner, China. The quantity and quality of improvements to global implementation and enforcement activities required is substantial.

Well-resourced countries that prioritize the North Korea issue, including the United States, Canada, South Korea and Australia, are now providing large-scale technical assistance, training, and capacity building programs for countries looking to bolster their implementation. According to Canada's Foreign Minister, Chrystia Freeland, "There are a lot of countries we have found in the world that have the political will to implement sanctions but lack the technical capacity." ${ }^{50}$ These technical assistance programs appear to only have begun gaining steam at the time of writing in mid-2018.

Another group of under-implementing states are those who are fully aware of their obligations and have the capacity to act upon them but choose not to. They may have disagreements with the use of sanctions as a foreign policy tool in general or in the specific context of North Korea. Russia is commonly cited as a country whose approach to North Korea sanctions implementation is shaped by its distaste for sanctions, not least because it too is a target of such measures by its adversaries. ${ }^{51}$ Other countries have ties to North Korea that they are interested in preserving. Pyongyang's customers for military goods and services are prime examples and are believed to have in recent years included Syria, Myanmar, Eritrea, Egypt, Angola, and Sudan. The advocates of the sanctions regime on North Korea often have little leverage over Pyongyang's closest partners, making it difficult, or even impossible, to sufficiently sway their thinking.

These explanations for national implementation shortcomings are by no means mutually exclusive. China, North Korea's top trading partner and the conduit by which most North Korean trade and financial interactions with the rest of the world flow, exhibits many of the characteristics described previously. Its record of implementing the very sanctions it has agreed to in the Security Council chamber is mixed. At any one time, China appears to be implementing some sanctions fairly robustly, others less so, and yet others not at all. The balance between these implementation levels fluctuates, as does the nature of the sanctions receiving attention. Monitoring is becoming steadily more challenging as China removes relevant data from the public space. ${ }^{52}$

Several factors may explain this array of approaches. Beijing remains skeptical of the use of sanctions as a tool to compel behavioral change in Pyongyang, preferring economic integration as the means by which to encourage a more stable and predictable relationship with its neighbors. Greater levels of compliance by China since the election of Donald Trump in the United States may indicate that 
its approach to implementation may not be guided not by thinking about the future of the North Korean nuclear issue but rather by efforts to influence its bilateral relationship with the United States and curate its image internationally. Limited additional cooperation can alleviate tensions in discussions with Washington and help shirk the international narrative that "China is not doing enough" on North Korea $^{53}$, likely without destabilizing the North Korea situation in the process. Some of China's implementation gaps may also be explained by competing priorities and difficulties coordinating action between central, provincial, and local government agencies.

In short, despite the sanctions regime being in place for over 11 years, implementation of UNSC resolutions is slow. Gaps remain across all aspects of the regime, from luxury goods to the arms embargo, to financial measures and sectoral sanctions. Deficiencies in the enforcement of measures imposed a year ago, and in enforcement of those imposed a decade ago, are still apparent. The rapid changes to sanctions designed by the UNSC since 2016, and the complexity of those newer measures, has added to the difficulty of compelling countries to take considered, robust actions to implement their international obligations. Improvements are under way but should not be taken for granted. Attentiveness to the North Korea issue that was driven by North Korea's own provocations may diminish as the global conversation shifts to engagement with Pyongyang. Similarly, many of the strides in implementation made by countries have occurred because of US pressure rather than organic concern over proliferation threats. And technical assistance programs are still in their infancy.

\section{North Korean evasive activity}

North Korea is determined to maximize the difficulties for implementers of effectively complying with their UN obligations. In the years since the first sanctions were adopted, North Korean networks have shown that they can deploy, layer, and adapt evasive measures to swiftly undermine the potential effectiveness of UN sanctions. Their sanctions circumvention effort is guided by a single, overarching principle: when conducting business overseas, conceal as many visible links to North Korea as possible. For certain activities or sectors, simple obfuscation tactics may suffice in ensuring that North Korean activities do not invite scrutiny from local or foreign authorities. For others, more complex workarounds are necessary.

During the Cold War period, North Korea set about expanding its business and trade footprints in countries overseas. It leveraged large diaspora communities in neighboring China and Russia but also looked further afield to Southeast Asia, the Middle East, Africa, and even Europe. Yet as its business reputation deteriorated, and as sanctions were eventually introduced in 2006, North Korea began to refrain from publicly branding its companies and activities as North Korean. It became practiced in establishing generically named front and shell companies abroad and creating complex corporate structures to obscure beneficial ownership. Today, 
comparatively few North Korean companies can be identified from their name or public presence alone.

\section{Evasion by North Korean corporate networks}

One example of the evolution of North Korean corporate evasion patterns is the Mansudae Overseas Group of Companies, North Korea's main construction firm working abroad. In Namibia, and elsewhere in Africa, the company used to operate transparently as Mansudae Overseas. The firm later changed its branding and paperwork to "MOP Architectural and Technical Services." ${ }^{54}$ After being exposed by UN investigators, the company's representatives embedded within a Chinese firm in Namibia, and then reformed their guise as "Tritonia Holdings," which the Namibian government flagged and deregistered in early $2018 .{ }^{55}$

A parallel trend has involved North Korean networks removing North Koreannational directors and shareholders from corporate paperwork in jurisdictions where this information is publicly available (such as Singapore and Hong Kong). Instead, these networks seek to exploit dual nationality or passport of convenience arrangements or look to partner with local national facilitators whose names will be used on documentation and who will often receive a cut of the profits. The North Korean partner will continue to exert control over the company's activities from the background, but their absence from corporate registry documents will make it difficult for external eyes to detect anything is amiss. Networks will also make active use of any local North Korean embassy, consulate, or trade mission to facilitate their illicit business.

\section{Skirting financial sanctions}

Comparable tactics are used by North Korea in the financial sector. In countries where North Korean nationality is not an automatic red flag for financial institutions, the country's nationals or diaspora will open personal or corporate accounts with financial institutions that are then used to facilitate not only their own finances but also those of an array of other North Korean companies. In jurisdictions where visible North Korean links would invite more scrutiny, bank accounts tend to be opened by local national facilitators and/or attached to front companies. The simple evasive tactics used in the registration of front companies will be enough to slide under the radar of most financial institutions. ${ }^{56}$

North Korean banks themselves employ this approach, not least because formal financial relationships between North Korean and foreign banks are now banned. Pyongyang has adopted a system whereby it deploys a representative of the bank overseas to open personal and front company bank accounts and then uses those bank accounts to perform the same services as a formal correspondent banking channel. Funds are moved between accounts controlled by North Korea around the world to receive and make payments related to the country's global business. Occasionally bulk cash is moved from these accounts back to North Korea. More commonly, North Korean bank representatives abroad simply record and 
compare a ledger of transactions with their bank's headquarters in Pyongyang, where changes are reflected in the account at home. This approach negates the need to transfer funds in and out of North Korea. ${ }^{57}$

\section{Circumvention when moving goods}

Goods flows with any obvious, paper link to North Korea are likely to invite more scrutiny than ever in the sanctions era. To address this, North Korean networks have traditionally routed these flows through China or Russia. For imports to North Korea, a front or partner company in a neighboring country will be named as the end user, and the product will subsequently be rerouted or reexported to North Korea. For North Korean exports, goods will be sent into China or Russia, and parties to the transaction will relabel them as having originated in those countries before sending them onwards to their final destination.

In some cases, the buyer or seller is aware of the scheme, while in others they are oblivious. North Korea managed to sell coal to buyers in several Southeast Asian countries by convincing the recipients, including the authorities at the receiving port, that the coal had in fact come from China or Russia. ${ }^{58}$ The scheme highlighted how North Korea's tactics have evolved as sanctions have expanded and slowly been better enforced. In certain cases, ships would turn off their transponders when entering North Korean waters to load coal. Once again outside of North Korean waters, they would turn on their transponder, sail to a Chinese port, and hover near it. Rather than calling at the port, parties to the transaction would falsify the ship's documentation to say that it had loaded coal in China before sailing to Southeast Asia to deliver the North Korean consignment. In cases involving Russia, North Korean-controlled ships would physically unload the coal at Russian ports before a foreign vessel would pick it up to take it to its destination shortly thereafter. The paperwork would be appropriately modified to suggest the coal originated in Russia. ${ }^{59}$

Countless other North Korean tactics have been identified by UN, governmental, and nongovernmental investigators, from the use of shipping flags of convenience, to moving goods in diplomatic bags, to writing "Korea" in the country field on official documentation in the knowledge that many will assume "South Korea" was intended. Simple, combined, widely replicated, and agile evasive tactics will make it disproportionately challenging for implementers to detect and act to counter illicit North Korean activity taking place on their soil.

Authorities must be aware of these activities when they assess their national risk exposure to potential illicit North Korean activity. They must be conscious of them when they craft laws and regulations, when they establish interagency processes, and when they outline intelligence gathering and monitoring operations. Yet few countries manage to look closely at their corporate networks, trade flows, and financial transactions to systematically identify North Korean connections that could violate sanctions. Instead, those with the political will to take stronger action appear to rely upon information shared by better resourced countries tracking North Korean activity around the world. Fueled by Pyongyang's sophisticated 
evasive tactics, the sanctions regime seems increasingly to depend upon the intelligence gathering and sharing efforts of the United States and its closest partners to deliver a tangible and timely impact.

\section{Conclusion: Uncertain trajectories}

At the time of writing, the future of the sanctions regime on North Korea seems particularly unclear. President Donald Trump and Kim Jong Un held a summit meeting in Singapore in June 2018, during which both leaders indicated their interest in transforming the security situation on the Korean Peninsula, including by actively pursuing denuclearization objectives. South Korea and China have indicated their support for this effort and are engaging in their own direct dialogue with the North. Any progress made on the North Korean nuclear file could result in the phased lifting of UN sanctions, autonomous measures, or both. The possibility remains also that President Trump will seek to declare victory on the North Korean nuclear issue at some undefined time, request complete sanctions lifting at the UN, and move on to other subjects. He could seek to unravel the sanctions regime as quickly as he expanded it.

Alternate trajectories for the sanctions regime exist as well. The importance that Pyongyang has continued to place on nuclear weapons as a key to national and regime survival, and the linking of the sanctions regime to the goal of North Korean disarmament highlights the potential that the Security Council will preserve sanctions for the foreseeable future. Any return to a more provocative relationship with North Korea, and to nuclear and missile testing by Pyongyang, could also result in the United States pushing for fresh sanctions in the Security Council. In any of these scenarios, the sustainability of the infrastructure supporting the sanctions regime is in doubt. The UN Panel of Experts monitoring the sanctions regime and promoting global awareness of North Korea sanctions evasion techniques is already over-stretched. Technical assistance programs currently driven by individual Member States could languish if political priorities shift or if they encounter greater implementation fatigue among recipient countries, especially if it appears that the North Korean disarmament is becoming a fantasy.

Furthermore, there is already growing concern that amidst the ongoing, highlevel engagement with North Korea, and in the face of rising tensions between Beijing and Washington over trade matters, China will ease its implementation of UN sanctions. ${ }^{60}$ Signs of this are already apparent at the time of writing in mid2018. Several media outlets reported busloads of North Korean migrant laborers - whose visas should be restricted by UN sanctions - returning to China. ${ }^{61}$ North Korean ships resumed regular visits to the coal terminal at a Chinese port of Longkou. ${ }^{62}$ Details of a Chinese ship engaging in a prohibited ship-to-ship transfer with a North Korean vessel were also published in May. ${ }^{63}$

These developments raise the possibility that even if sanctions remain in place on paper, their value could be diminished in practice by implementation backsliding. This is not only a possibility in China, and it could transpire in the short-, medium-, or long-term. A notable portion of the implementation and enforcement 
progress made in the last 18 months has occurred because North Korean provocations raised the profile of the Korean Peninsula security situation on the global agenda and because the US and its like-minded partners began leaning more heavily on a variety of States to take action to implement UN sanctions. Yet there are risks associated with securing progress by applying pressure. Should the international conversation over North Korea change and US lobbying efforts ease, countries or even private sector implementers are likely to reduce their level of attentiveness to North Korea sanctions as well. ${ }^{64}$

For now, many countries around the world will continue to grapple with the daunting task of translating a range of still fresh UN obligations into national law and practice, while North Korean networks fight to undermine their efforts. The architects of the sanctions regime, for their part, will be occupied by another task: having designed one of the most complex and wide-ranging sanctions regimes in history, they now need to consider what the exit ramp should look like. American and South Korean officials have reiterated that sanctions will remain in place until "complete denuclearization has been achieved." ${ }^{65}$ While this may be long-standing Security Council policy that countries supporting the sanctions regime worldwide have acknowledged, never before has that consensus seemed so fragile.

\section{Notes}

1 “Kim Jong Un's 2018 New Year's Address," (January 1, 2018), available at <www. ncnk.org/node/1427>.

2 Ibid.

3 "Final Report of the Panel of Experts Submitted Pursuant to Resolution 2345 (2017)," U.N. Doc. S/2018/171 (2018).

4 "Press Statement by First Vice-Minister of Foreign Affairs of DPRK," Korean Central News Agency (May 16, 2018), available at <https://kcnawatch.co/newstream/1526482853-432433886/press-statement-by-first-vice-minister-of-foreign-affairsof-dprk/>.

5 David E. Sanger, "North Koreans Say They Tested Nuclear Device," New York Times (October 9, 2006), available at <www.nytimes.com/2006/10/09/world/asia/09korea. html>.

6 U.N. Doc. S/RES/1718 (2006).

7 Ibid.

8 These considerations are discussed in greater detail in Andrea Berger, "A House Without Foundations: The North Korea Sanctions Regime and Its Implementation," RUSI Whitehall Report 3-17 (2017), p. 5. For a discussion on North Korea's negotiating considerations at the time, see Stephan Haggard and Marcus Noland, "North Korea in 2007: Shuffling in from the Cold," Asian Survey, Vol. 48, No. 1 (2008), pp. 107-115.

9 U.N. Doc. S/RES/1737 (2006). Indeed, the similarities are partially a result of political and negotiating dynamics. Having already secured agreement on particular language in a resolution on DPRK, it was easier for negotiators to convince their counterparts to subsequently adopt similar language on Iran. The author is grateful to Richard Nephew for this point.

10 U.N. Doc. S/RES/1747 (2007).

11 The luxury goods ban is an exception.

12 Kelsey Davenport, “The Six-Party Talks at a Glance," Updated June 2018, available at $<$ www.armscontrol.org/factsheets/6partytalks $>$. 
13 For a reflection on the agreement, see Ankit Panda, "A Great Leap to Nowhere: Remembering the US-North Korea 'Leap Day' Deal," The Diplomat (February 29, 2016), available at <https://thediplomat.com/2016/02/a-great-leap-to-nowhereremembering-the-us-north-korea-leap-day-deal/>.

14 "Executive Order - Imposing Additional Sanctions With Respect to North Korea," (January 2, 2015), available at <https://obamawhitehouse.archives.gov/the-pressoffice/2015/01/02/executive-order-imposing-additional-sanctions-respect-north-korea>. See also Andrea Berger, "New Kids on the Blocked Persons List: US Expands North Korea Sanctions," Royal United Services Institute(December 14, 2015), available at $<$ https://rusi. org/commentary/new-kids-blocked-persons-list-us-expands-north-korea-sanctions>.

15 See, for example, Euijin Jung, "Iran Sanctions: A Successful Episode," available at $<$ https://piie.com/blogs/trade-investment-policy-watch/iran-sanctions-successfulepisode>. Josh Cassidy, "The Iran Deal Is a Victory for Reason and Economic Sanctions," The New Yorker (September 3, 2015), available at <www.newyorker.com/news/johncassidy/the-iran-deal-is-a-victory-for-reason-and-economic-sanctions $>$. See also the extensive discussion in Richard Nephew, The Art of Sanctions: A View from the Field (2018).

16 "DPRK to Adjust Uses of Existing Nuclear Facilities," Korean Central News Agency (April2,2013), availableat $<$ https://kcnawatch.co/newstream/1451895823-698999602/ dprk-to-adjust-uses-of-existing-nuclear-facilities/>.

17 "Law on Consolidating Position of Nuclear Weapons State Adopted," Korean Central News Agency (April 1, 2013), available at <https://kcnawatch.co/newstream/ 1451896124-739013370/law-on-consolidating-position-of-nuclear-weapons-stateadopted/>.

18 "Asian Buyers to Deepen Iranian Crude Import Cuts in 2013," Reuters (December 23, 2012), available at $<$ www.reuters.com/article/oil-iran-asia/rpt-update-1-asian-buyersto-deepen-iranian-crude-import-cuts-in-2013-idUSL4N09V3HK20121223>.

19 These countries include North Korean military customers and general trading partners, countries home to North Korean business communities or diplomatic presences, and common trade routes for products going to or from North Korea.

20 "North Korea Fires Long-Range Rocket Despite Warnings," $B B C$ (February 7, 2016), available at $<$ www.bbc.co.uk/news/world-asia-35515207>.

21 Chinese imports of coal from North Korea increased following Resolution 2270. Benjamin Katzeff Silberstein, "Is China Serious About Banning North Korean Coal?" The Diplomat (February 21, 2017), available at $<\mathrm{https}$ ://thediplomat.com/2017/02/ is-china-serious-about-banning-north-korean-coal/>.

22 "Fact Sheet: DPRK Resolution 2270 (2016)," (March 2, 2016), available at $<$ https:// geneva.usmission.gov/2016/03/03/fact-sheet-dprk-resolution-2270/>.

23 U.N. Doc. S/RES/2270 (2016). Such thinking was embedded in Resolution 2270 as a preamble: "Regretting the DPRK's diversion of financial, technical and industrial resources toward developing its nuclear weapons and ballistic missile program."

24 Almost all officials and experts working on North Korea sanctions who were consulted informally by the author in the period since December 1,2016, have said they did not expect China to agree to the number and type of new/expanded measures proposed.

25 U.N. Doc. S/RES/2270 (2016).

26 U.N. Doc. S/Res/2321 (2016).

27 U.N. Doc. S/Res/2371 (2017).

28 For example, recent resolutions have clarified what Member States can choose to do with any cargo seized in fulfilment of their UNSC obligations. See U.N. Doc S/ $\mathrm{RES} / 2375$. These practicalities had not previously been clear in relevant UN sanctions provisions and had been a source of difficulty for states carrying out interdictions and seizures.

29 "Remarks at the UN Security Council Ministerial Meeting on D.P.R.K," (December 15, 2017), available at $<\mathrm{https}$ //vienna.usmission.gov/latest-north-korean-developmentsu-s-statements/>. 
30 Gaps in implementation by UN Member States and private sector stakeholders, as well as evasive tactics adopted by North Korea, make it more difficult to establish these linkages. Consequently, many transactions which may breach sanctions are never identified as being of particular concern.

31 Sanctions imposed in relation to North Korean military trade with Myanmar were also lifted by President Obama as part of his decision to remove sanctions on Naypyidaw. See "Obama Orders US Economic Sanctions on Myanmar Lifted," Al Jazeera (October 7, 2016), available at <www.aljazeera.com/news/2016/10/obama-economicsanctions-myanmar-161007215716882.html>. United Nations investigators later reported that North Korea was indeed continuing to sell ballistic missile, surface-to-air missile, and other conventional weapons technology to the Myanmar military in defiance of UN sanctions on Pyongyang. See: U.N. Doc. S/2018/171, p. 43.

32 Using autonomous sanctions in this way is not unique to the Trump Administration. Since coming into office, however, the administration has used unilateral sanctions on shipping networks in some cases as a prelude to discussions in the UNSC and in other cases as a response to them. "Treasury Announces Largest North Korea Sanctions Package Targeting 56 Shipping and Trading Companies and Vessels to Further Isolate Rogue Regime," (February 23, 2018), available at $<$ https://home.treasury.gov/news/ press-releases/sm0297>; see also the subsequent UN Sanctions Committee action: "Security Council 1718 Sanctions Committee Adds 22 Entries to Its Sanctions List, Designates 27 Vessels," (March 30, 2018), available at <www.un.org/press/en/2018/ sc13272.doc.htm>.

33 At the time of writing, no new sanctions on North Korea have been adopted by the US since February 2018.

34 "USAccuses Bank ofDandong ofDealings With North Korea," Financial Times (June 29, 2017), available at $<$ www.ft.com/content/5cc01814-5d48-11e7-9bc8-8055f264aa8b $>$.

35 "US Bars Chinese Bank Linked to North Korean Weapons Programme," Financial Times (November 2, 2017), available at <www.ft.com/content/ c6c2d0fa-c051-11e7-9836-b25f8adaa111>.

36 Sarah N. Lynch, "U.S. Justice Department Seeks \$11 Million in Forfeiture from Firms With Ties to North Korea," Reuters (August 22, 2017), available at <www.reuters. com/article/us-northkorea-nuclear-forfeiture/u-s-justice-department-seeks-11-millionforfeiture-from-firms-with-ties-to-north-korea-idUSKCN1B21WC>.

37 “與朝鮮航運方法相關的制裁風險 [Sanctions Risks Relating to North Korean Shipping Practices]," (February 23, 2018), available at <www.treasury.gov/resource-center/ sanctions/Programs/Documents/dprk_vessel_advisory_chinese.pdf $<$.

38 Andrew Prokop, "Trump: Maybe We'll End All Trade With Countries That Trade With North Korea: Everyone: Huh?" VOX (September 3, 2017), available at <www.vox. com/2017/9/3/16249504/trump-north-korea-trade-tweet>.

39 "Report: Egypt Cuts Military Ties With North Korea," US News (September 12, 2017), available at <www.usnews.com/news/world/articles/2017-09-12/ egypts-top-commander-says-ties-with-pyongyang-severed\#close-modal>.

40 Gazetted sanctions lists are available from South Korea's Interior Ministry at $<$ http:// gwanbo.mois.go.kr/>.

41 See, for example, the sanctioning of the Korea National Insurance Corporation office in Germany. "North Korea: EU Adds Korea National Insurance Company and Six Senior Employees to Sanctions List," (July 10, 2015), available at <www.lexology. com/library/detail.aspx?g=c07d735c-3427-4fc5-ac42-1d639db33c19>.

42 The European Union banned sales of crude oil to North Korea several months before this requirement was incorporated into a Security Council resolution. "North Korea: EU Aligns Sanctions With Latest UN Security Council Resolution," (February 26, 2018), available at <www.consilium.europa.eu/en/press/press-releases/2018/02/26/ north-korea-eu-aligns-sanctions-with-latest-un-security-council-resolution/> . 
43 "Presidential Executive Order Imposing Additional Sanctions With Respect to North Korea," (September 21,2017), available at $<$ www.whitehouse.gov/presidential-actions/ presidential-executive-order-imposing-additional-sanctions-respect-north-korea/>.

44 A similar measure relating to shipping has also existed in Japanese law for some time. Christopher W. Hughes, "The Political Economy of Japanese Sanctions Towards North Korea: Domestic Coalitions and International Systemic Pressures," Pacific Affairs, Vol. 79, No. 3 (2006), p. 433.

45 Leo Byrne, "Seoul Adds New Sanctions on North Korea," NK News (March 8, 2016), available at <www.nknews.org/2016/03/seoul-adds-new-sanctions-on-northkorea/?c=1528700749551>.

46 Ibid.

47 Dagyum Ji, "S. Korea Unveils Unilateral Fresh Sanctions Against N. Korea," NK News (December2,2016), availableat $<$ www.nknews.org/2016/12/s-korea-unveils-unilateralfresh-sanctions-against-n-korea/?c=1509940839382>.

48 Berger, supra note 8, p. 31.

49 Andrea Berger, "Guest Post: The Chinpo Shipping Case Implodes," Arms Control Wonk Blog (May 15 2017), available at <www.armscontrolwonk.com/archive/1203164/ guest-post-the-chinpo-shipping-case-implodes/>.

50 For example: Katie Simpson, "Canada Makes \$3.25M Contribution to U.S. Program Enforcing Sanctions on North Korea," CBCNews (January 16,2018), available at $<$ www. cbc.ca/news/politics/north-korea-summit-vancouver-freeland-tillerson-1.4489166>.

51 "North Korea Nuclear Crisis: Putin Calls Sanctions Useless," BBC News (September 5, 2017), available at <www.bbc.co.uk/news/world-asia-41158281>. See also, Andrei Lankov, "Why Russia May Use Its Veto Power on New North Korea Sanctions," NK News (September 10, 2017), available at <www.nknews.org/2017/09/ why-russia-may-use-its-veto-power-on-new-north-korea-sanctions/ $>$.

52 In early 2017, China withdrew third-party service provider access to shipmentlevel China-DPRK trade data. In early 2018, it began wiping corporate registry data for companies deregistered for reasons related to North Korea. Catherine Dill, "A Note on China's Implementation of UNSCR 2375," Arms Control Wonk Blog (May 16, 2018), available at <www.armscontrolwonk.com/archive/1205203/ a-note-on-chinas-implementation-of-unscr-2375/>.

53 See, for example, Steve Holland and Matt Spetalnick, "Trump to Press China on North Korea, Trade on Beijing Visit," Reuters (October 23, 2017), available at $<$ www.reuters.com/article/us-northkorea-missiles-usa/trump-to-press-china-onnorth-korea-trade-on-beijing-visit-idUSKBN1CS1XA>.

54 See U.N. Doc. S/2018/171, paras. 104-108. Mansudae is also registered in the Democratic Republic of the Congo as "MOP Architectural and Technical Services." Corporate registry documents held by the author.

55 "Final Deregistration of Companies: Companies Act, 2004," Government Gazette of the Republic of Namibia (January 31, 2018), available at $<$ https://laws.parliament.na/ cms_documents/6521-a98a0bdb11.pdf >.

56 For an example of this pattern, see the discussion of the Chinpo Shipping case in Berger, supra note 49.

57 This system is discussed extensively in UN Panel of Experts reports. See U.N. Doc S/2018/171. See also the excellent descriptions of North Korean financial patterns in "Risky Business: A System-Level Analysis of the North Korean Proliferation Financing System," C4ADS Report (2017). See also the study on proliferation finance typologies in Jonathan Brewer, "Study of Typologies of Financing of WMD Proliferation," King's College London Report (2017).

58 U.N. Doc S/2018/171, pp. 21-28.

59 Ibid. 
60 Christy Lee, "North Korea-China Thaw Could Undermine International Sanctions," Voice of America (April 7, 2018), available at <www.voanews.com/a/thaw-betweennorth-korea-china-could-undermine-international-sanctions/4336619.html>.

61 Elizabeth Shim, "North Korea Workers Returning to China, Sources Say," UPI (April 5, 2018), available at $<$ www.upi.com/North-Korea-workers-returning-to-Chinasources-say/5931522939234/>.

62 Leo Byrne, "North Korea Ship Returns to Longkou Coal, Iron Handling Port," NK News (June 14, 2018), available at <www.nknews.org/pro/north-korean-shipreturns-to-longkou-coal-iron-handling-port/>.

63 Alastair Gale, "North Korea Skirts Sanctions With Ship Transfers Over Wider Area," Wall Street Journal (May 29, 2018), available at <www.wsj.com/articles/ north-korea-skirts-sanctions-with-ship-transfers-over-wider-area-1527606731>.

64 Exceptions to this dynamic will be any changes secured that take the form of legal or regulatory development, or systematic processes that the state integrates into its national practices in an enduring fashion.

65 "North Korea Sanctions to Remain Until Denuclearization Achieved: South Korean Minister," Reuters (June 20, 2018), available at <www.reuters.com/article/usnorthkorea-usa-southkorea/north-korea-sanctions-to-remain-until-denuclearizationachieved-south-korea-minister-idUSKBN1JG06Q>. 


\title{
10 Iran
}

\section{The role and effectiveness of UN sanctions}

\author{
Kazuto Suzuki*
}

\section{Introduction}

The sanctions against Iran have been, and still are, the most successful case of sanctions imposed by the United Nations. ${ }^{1}$ Sanctions are designed to bring the target State to the negotiation table to settle its issues peacefully. In this regard, Iran came to the table and negotiated for two years, which was followed by adoption of the Joint Comprehensive Plan of Action (JCPOA). ${ }^{2}$ The success of the sanctions against Iran might have played a role in the decision made by the Trump Administration to withdraw from the JCPOA because it proved that the sanctions against Iran worked very well, and the Trump Administration might have believed that it could replicate their success and negotiate a "better" deal. ${ }^{3}$

This chapter will explain the purposes and means of UN sanctions, as well as their impact and effectiveness. Initially, the sanctions focused mainly on the importation of nuclear and missile-related items by Iran, but gradually the sanctions were toughened to include an arms embargo and provisions with regard to cargo inspections in addition to financial provisions. Eventually Iran changed its policy and negotiated to lift the sanctions with the P5+1 (or EU3 $+3^{4}$ ) with help from unilateral sanctions by major industrial powers, and it may be difficult to distinguish between the effectiveness of UN and unilateral sanctions; however, this chapter will argue that the JCPOA could not have been concluded had there been no UN sanctions.

\section{Legitimacy of UN sanctions}

The implementation of the UN sanctions is based on their legitimacy and legality. ${ }^{5}$ Article 39 of the Charter of the United Nations authorizes the Security Council to determine the existence of any threat to the peace, breach of the peace, or act of aggression and shall make recommendations, or decide what measures shall be taken to maintain or restore international peace and security. ${ }^{6}$ Once the existence of a threat is determined, the Security Council may, according to Article 40, call upon the parties concerned to comply with provisional measures as it deems necessary or desirable. ${ }^{7}$ In the case of the sanctions against Iran, Security Council 
Resolution 1696 (2006) ${ }^{8}$ was based on Article 40. This resolution was adopted after the IAEA report that demanded actions to force Iran to take steps to resolve concerns about the development of nuclear activities. It also expresses

its intention, in the event that Iran has not by that date complied with this resolution, then to adopt appropriate measures under Article 41 of Chapter VII of the Charter of the United Nations to persuade Iran to comply with this resolution and the requirements of the IAEA. ${ }^{9}$

As stated in UNSCR 1696, if the State, entity, or individuals are not in compliance with the measures based on Article 40, the Security Council may take the measures defined in Article $41 .^{10}$ This article allows the Security Council to take measures not involving the use of armed force to give effect to its decisions, and it may call upon the Members of the United Nations to apply such measures. These may include complete or partial interruption of economic relations and of rail, sea, air, postal, telegraphic, radio, and other means of communication, as well as the severance of diplomatic relations. ${ }^{11}$

Based on Article 41 of Chapter VII, the Security Council may decide which measures to be taken to force States or individuals to comply with UN Security Council resolutions and to restore peace. For many years, it was believed that the full implementation of Article 41, namely complete economic sanctions, would be the most effective tool for bringing States or individuals to the negotiating table. However, stringent sanctions on Iraq on account of the invasion of Kuwait (UNSCR $661^{12}$ ) and the development of weapons of mass destruction after the Gulf War (UNSCR $687^{13}$ ) were the turning points in determining the philosophy of how UN sanctions should be conducted. ${ }^{14}$

Near total sanctions on financial activities and trade with Iraq were not effective in making it comply with the requirements of the UNSCRs. Saddam Hussein, as a dictator, cut off the economy of Iraq, and the Iraqi people suffered. The sanctions on Iraq only harmed the livelihoods of ordinary people while placing less pressure on the dictator and his government. In other words, the measures taken by the UN, an organization that is supposed to promote human rights and economic development, created a disastrous situation for the Iraqi people in practice. $^{15}$

Faced with international claims that the UN was creating a human catastrophe in Iraq, the UN launched a program called "Oil-for-Food," which was meant to preserve the principles of financial and trade sanctions while providing humanitarian aid, such as food and medicine, to the Iraqi people. However, this "Oil-for-Food" program was not satisfactory in terms of scale and procedure. There were many problems, including large-scale corruption and uneven distribution, and there was little improvement in humanitarian conditions. The complete economic sanctions against the dictatorial regime had an effect that contravened the purposes and objectives of the UN itself. Thus, the UN took actions to review and revise its ways and means of implementing sanctions. ${ }^{16}$ 


\section{Interlaken and Bonn/Berlin processes}

Based on the lessons learned from the sanctions against Iraq, Switzerland, Germany, and Sweden took the initiative to launch a comprehensive review of sanctions. The first was the Interlaken process, which took place between 1999 and 2000 under the sponsorship of Switzerland. ${ }^{17}$ This process yielded the concepts of "smart sanctions" and "targeted sanctions," which depart from the traditional practice of comprehensive economic sanctions. "Smart," or "targeted," sanctions focus on the items and individuals/entities that are involved in prohibited activities.

As the first step of the sanctions review, the Interlaken process took up the issue of the financial aspect of sanctions. Those involved in the process argued that financial sanctions should be coercive measures taken against transgressing parties, including decision makers, the elites supporting them, or individuals and entities undertaking prohibited activities, with the goal of changing their behaviors. Directly applying financial measures to these individuals and entities would have a straightforward effect on their behavior while leaving the livelihoods of ordinary people intact. Switzerland, as one of the global financial hubs, helped shape the legal and technical instruments for targeted financial sanctions as well as the definitions of "financial assets." "One of the main instruments proposed in the Interlaken process report was the "asset freeze." The report argues that it should not apply only to funds but also other financial resources owned and controlled by designated individuals or entities, and they should not be made available. ${ }^{19}$

The second process of sanctions review was conducted under German leadership in 2000 and was known as the Bonn/Berlin process. Following the idea of "smart/targeted" sanctions, it focuses on the questions of an arms embargo and travel ban. The arms embargo and travel ban were not new, but past experience of the implementation of these measures had shown that they were not effective, according to the report. ${ }^{20}$ Thus, the discussion focused mainly on the ways to improve the implementation process. Regarding the arms embargo, various technical instruments, such as identifying arms dealers and brokers, export licenses for arms export, including small arms, and requirements for end-user certificates ${ }^{21}{ }^{2}$ were identified. Regarding the travel ban, those who participated in the review debated the extent of "acting on behalf" of designated individuals or entities, the definition of "family" and control over aliases and forged documents. One of the problems was how to balance the rights of individuals with the imposition of a travel ban. There were several questions raised, and in practice, these issues should have been handled by the Sanctions Committee under the Security Council, which has authority to grant an exemption or waiver. ${ }^{22}$

\section{Stockholm process}

The third process of sanctions review was the Stockholm process, which was led by Sweden in 2002-2003. Unlike the Interlaken and Bonn/Berlin processes, the Stockholm process focused on the implementation of sanctions. Smart, or 
targeted, sanctions could not be effective if evasive strategies were taken by the targeted individuals or entities. The most important issue, according to the report of Stockholm process, ${ }^{23}$ was that the Security Council, sanctions committee, Member States, administrative agencies, and nongovernmental organizations, including companies and traders, must be on the same page when attempting to implement the measures defined by UNSCRs. In this way, sanctions are not only the affairs of international organizations; thus, everyone, including companies and individuals, is responsible for implementing sanctions.

The Stockholm process yielded recommendations for improving implementation, from changing the design of sanctions to reporting them. One of the important innovations in sanctions implementation produced by this process was the establishment of Expert Panels and Monitoring Mechanisms for follow-up implementation. ${ }^{24}$ This is important because smart/targeted sanctions require a lot of expertise on the technical aspects of targeted items and the activities of designated individuals and entities. The Panel has the authority to investigate incidents of sanctions violations and report them to the wider public to raise awareness of sanctions evasion techniques.

This process also reiterated the importance of the design of sanctions, which brings clarity to their objectives and instruments, the need to build the capacity of law enforcement agencies so that there will be a level playing field and the need for flexibility in sanctions regimes to accommodate the various objectives and targets of sanctions. ${ }^{25}$

These recommendations were extremely important regarding the UN sanctions in comparison to unilateral sanctions. Unilateral sanctions often have clear objectives with a means of implementation and law enforcement mechanisms, while UN sanctions require a lot of coordination, outreach, and training to ensure that there will be no loopholes in their implementation. Sanctions often have a limited effect if there are loopholes, since they allow prohibited items to be transferred to the targets, and designated individuals can travel through those loopholes. UN sanctions are, in theory, the only sanctions regime that would be effective in implementing restrictive measures, but this is only possible as long as all Member States are engaged in such measures.

\section{Outline of UN sanctions against Iran}

The sanctions against Iran were the second case in which the new concept of "smart/targeted sanctions" was applied to nonproliferation, occurring after concerns about the nuclear program of the DPRK (Democratic People's Republic of Korea, or North Korea). Both Iran and the DPRK developed their nuclear capabilities through clandestine transactions with A.Q. Khan, who is considered the "Father of Pakistani nuclear capability" and has simultaneously spread nuclear technology through black markets. ${ }^{26}$ Iran's nuclear activities were revealed by an Islamic and socialist group called Mojahedin-e Khalq (MEK), which advocated overthrowing the current Islamic Republic regime of Iran in 2002. ${ }^{27}$ After this revelation, President Khatami began negotiating with the United Kingdom, France, 


\section{Kazuto Suzuki}

and Germany (EU3) without leaving the NPT. In 2004, the EU3 and Iran decided to allow the IAEA to inspect nuclear facilities in the same manner as the Additional Protocol (AP) of the IAEA Comprehensive Safeguard Agreement, even though Iran had not ratified the AP. The EU3 and Iran also agreed that Iran would retain its uranium enrichment capability, under strict inspection by the IAEA, for peaceful use. ${ }^{28}$ This conclusion was unsatisfactory for those who were skeptical about Iran's intention to develop such capabilities, and they were not convinced that Iran would honor its commitment. The agreement was not fully implemented when Mahmoud Ahmadinejad was elected as president of the Islamic Republic of Iran in 2005. Ahmadinejad rejected the agreement with the EU3, and he reinforced nuclear activities, including the construction of the Arak heavy water reactor and an increase in the number of centrifuges at the Fordow and Natanz nuclear facilities. $^{29}$

In June 2006, the Director-General of the IAEA issued a report $^{30}$ that highlighted the noncompliance of Iran in taking the steps to halt its nuclear activities that the IAEA Board of Governors had requested. In consideration of Iran's noncompliance, the Security Council adopted UNSCR $1696(2006)^{31}$ under Article 40 to call upon Iran to comply with the IAEA's requests. However, Iran ignored the warning of UNSCR 1696 and continued the development of its nuclear facilities, which was further reported by the Director-General of the IAEA in August $2006^{32}$ and November $2006 .^{33}$

\section{UNSCR 1737 (2006)}

UNSCR 1737 was the first of four sanctions resolutions taken on Iran's nuclear activities. It defines the targets as "all enrichment-related and reprocessing activities, including research and development" and "all heavy water-related projects, including the construction of a research reactor moderated by heavy water." ${ }^{34}$ This resolution only targets those activities and those who are related to them, which means that it has little or no impact on the livelihoods of ordinary people.

To prevent Iran from taking actions to engage in these nuclear activities, the Security Council prohibits the transfer of items listed in the NSG (Nuclear Suppliers Group), ${ }^{35}$ except those related to light water reactors, since the light water reactor constructed by Russia is operated in Bushehr in Southwest Iran. In other words, humanitarian items, such as food and medicine, are not included in the list of prohibited items, and even though items that have dual-use aspects are listed in this resolution, it only prohibits certain items that are above technical thresholds or parameters. For example, aluminum is used in constructing centrifuges but can also be used in many ordinary products, so that the only prohibited type of aluminum is that which is "capable of an ultimate tensile strength of 460 $\mathrm{MPa}$ or more at $293 \mathrm{~K}\left(20^{\circ} \mathrm{C}\right)$ and in the form of tubes or cylindrical solid forms (including forgings) with an outside diameter of more than $75 \mathrm{~mm} .{ }^{36}$ Any other aluminum or aluminum alloy is permissible to export to Iran for industrial and commercial use because the other types are not likely be used for developing Iran's nuclear capabilities. Although the development of nuclear weapon delivery 
system was mentioned several times in this resolution, there was no explicit provision to prohibit the supply, sale, or transfer of items that might contribute to the development of such a delivery system.

The resolution also prohibits "any technical assistance or training, financial assistance, investment, brokering or other services, and the transfer of financial resources or services" related to nuclear activities. ${ }^{37}$ All Member States are obliged to report any entry or transit of designated individuals and to freeze "the funds, other financial assets and economic resources" of designated individuals and entities. ${ }^{38}$ What is interesting in this measure is that the Security Council decided to include financial instruments but limited them to the financing of prohibited activities and assets held by designated individuals and entities. It is also interesting to examine the definition of "assets"; assets are defined funds, financial assets, and "economic resources." This goes beyond the financial instruments but also includes economic resources, including real estate, vessels, and aircrafts. There may be issues regarding the seizure of these physical assets. ${ }^{39}$

All Member States are also required to report the steps taken to implement this resolution. In theory, the Security Council's resolutions are legally binding on all Member States, but there is a wide diversity in implementation capabilities. ${ }^{40}$ Thus, it is important to monitor the capabilities of all Member States and use this information to ensure that Member States that do not possess sufficient capacity can improve their implementation of the resolutions.

\section{UNSCRs 1747 (2007) and 1803 (2008)}

Since there were no signs that Iran would change its behavior, the Security Council took further actions. In March 2007, the Security Council unanimously adopted UNSCR 1747 (2007), ${ }^{41}$ which prohibited Iran from supplying, selling, or transferring any arms or related materiel. ${ }^{42}$ This measure was taken in order to target the entities involved in nuclear activities and the development of nuclear weapons delivery systems. The entities involved in these activities were directly or indirectly related to Iran's Islamic Revolutionary Guard Corps (IRGC), a largescale militia taking direct orders from the Supreme Leader, not the President. In other words, the Iranian government does not have full control over the activities of the IRGC, even though the government must represent Iran in the international arena. ${ }^{43}$ While the government is committed to continuing its membership in the Non-Proliferation Treaty (NPT) and peaceful use of nuclear technology, the IRGC has acted differently. Thus, the Security Council focused on the arms trade, which generates an independent source of income for the IRGC, which is funded by the national budget as well as its own foundation and economic entities, such as Khatam-al-Ambiya (KAA) and the Defense Industry Organization (DIO). ${ }^{44}$

UNSCR 1803 (2008), ${ }^{45}$ which was adopted with 14 in favor, zero against, and one abstention (Indonesia) on March 3, 2008, did not add any substantial new elements to the UN sanctions regime against Iran, but it was meant to place additional pressure on the country, with the stringent application of a travel ban and an asset freeze on designated individuals and entities. There was general frustration 
among the Member States of the Security Council because Iran continued to deny cooperation with the IAEA for inspections, and it felt that there should be more pressure, even though Iran maintained the position that its nuclear program was solely for peaceful purposes. There was no consensus on imposing further sanctions measures, but the majority of Member States, including permanent members, thought that there should be a resolution to demonstrate the willingness of the Council to promote diplomatic solutions while preventing further proliferation of nuclear technology. Thus, this resolution added 30 individuals involved in nuclear and missile activities and a dozen entities to the designation list. ${ }^{46}$

\section{UNSCR 1929 (2010)}

After the Iranian presidential election in 2009, in which Mahmoud Ahmadinejad, a conservative hardliner with a strong anti-US position, was reelected, there was a popular uprising of young people in Iran who believed that the presidential election had been rigged, which was called the "Green Movement." The Ahmadinejad government mobilized the Basij militia force (affiliated with the IRGC) to oppress the "Green Movement" and put reformist politicians under house arrest. Ahmadinejad believed that the "Green Movement" had been organized and supported by foreign powers and accelerated its nuclear program (although there is no evidence that he advanced the military nuclear program) ${ }^{47}$

Under these circumstances, the United States and others prepared a new resolution to impose stronger sanctions on Iran, which was put up for a vote on June 9, 2010, and was adopted, with 12 States in favor, Brazil and Turkey against the measure, and Lebanon abstaining from voting. The resolution, UNSCR 1929 (2010), ${ }^{48}$ strengthened the arms embargo on Iran importing any arms listed on the United Nations Register of Conventional Arms or related materiel and receiving related technical training, financial resources or services, advice, or any other assistance. ${ }^{49}$ This clause aimed at squelching the funding and capabilities of the IRGC to use force against its own people. This resolution also prohibited Iran from undertaking any activities related to missile launches or using ballistic missile technologies (including satellite launches to space). Although nuclear delivery system development was prohibited by UNSCR 1737, there was no explicit clause prohibiting missile tests or any launch activities.

One of the additional measures included in UNSCR 1929 for tightening sanctions was so-called "catch-all" clause. According to this clause, States can supersede "any further items if the State determines that they could contribute to" prohibited activities. Thus, States shall "catch all" items that it has reason to believe could contribute to prohibited activities. ${ }^{50}$ The concept of a "catch-all" is becoming popular in the world of export control or security trade control, which allows States to interdict items that are not on the lists of prohibited goods. Sometimes States, like Iran, may import items that are below the threshold defined in the NSG or MTCR (Missile Technology Control Regime) lists and upgrade them to previous threshold items. For example, Iran may import a milling machine to curve pipes for a centrifuge or nuclear reactor with four axes. Since NSG list part 
2 (dual-use item list) defines any milling machine above five or more axes as prohibited, Iran can legitimately acquire a four-axes machine tool. ${ }^{51}$ However, some milling machines may have an attachment that allows the addition of one or more axes to the original machine. In this way, Iran may acquire a milling tool with five or six axes, which would be capable of producing pipes suitable for prohibited activities. Thus, the "catch-all" is important for preventing Iran from acquiring items under the threshold and upgrading them.

The resolution also called upon Member States to exercise vigilance in financial transactions that could contribute to Iran's prohibited activities in addition to implementing the asset freeze of designated individuals and entities. ${ }^{52}$ The financial transactions for proliferation of weapons of mass destruction are now regulated under the recommendations of the Financial Action Task Force (FATF), but this resolution had already implied such regulations. Furthermore, in order to prevent Iran from acquiring items related to prohibited activities, this resolution noted that Member States may request inspection of vessels at high sea, in accordance of international law, if they had reasonable ground to believe that the cargo was contributing to prohibited activities. ${ }^{53}$ The past resolutions called upon Member States to inspect such cargo in their territorial waters, but UNSCR 1929 extended, albeit in weaker language, Member States' ability to inspect vessels on the high seas. This appears to suggest that activities like the Proliferation Security Initiative are aligned with the UN sanctions scheme.

UNSCR 1929 established the panel of eight experts to gather, examine, and analyze information from a variety of sources and provide assistance to the Security Council and Sanctions Committee. ${ }^{54}$ Before this resolution, the information provided to the sanctions committee was analyzed and reported by the group of diplomats in the committee. Since sanctions against proliferation require a high degree of technical expertise and knowledge of details, the panel was established. Not only do sanctions cover dual-use items and the arms trade, but they also cover financial transactions, the activities of designated individuals, and a complex web of procurement channels. Analysis requires dedicated attention by experts on export control, arms and ammunitions, nuclear and missile technologies, maritime transportation, and so on. The work of the panel extends to a wide variety of issues related to Iran's prohibited activities, and it reports the results of investigations into incidents that may violate UNSCRs. The annual reports, as public documents, provide detailed information on the methods and modalities of Iran's sanctions evasion and demonstrate the various techniques used to circumvent sanctions. By announcing them publicly, the panel raises the awareness of all Member States, companies, and individuals about issues and items that may contribute to Iran's prohibited activities. This outreach program is one of the important factors in the effectiveness of UN sanctions.

\section{Unilateral sanctions}

The concept of "smart" or "targeted" sanctions is well suited for the purpose of the United Nations and its humanitarianism. However, the effectiveness of 
sanctions - putting pressure on the target to change its behavior - is not immediately apparent. Prohibiting trade in items related to nuclear and missile activities will certainly delay the process of Iran's development of those capabilities, but Iran has developed various means to circumvent sanctions by finding loopholes and trading in below-threshold items. ${ }^{55}$ Although many Member States complied with the UNSCRs, some States may implement them better than others. Iran was keen to find those "weakest links" to avoid being caught by inspections by the UN Panel of Experts or national intelligence services. Thus, pressure on Iran through UN sanctions alone had a limited impact on Iran's decision-making process.

\section{Impact of secondary sanctions}

On the other hand, sanctions unilaterally imposed by Member States, particularly the United States, had a great impact on the behavior of Iran's illicit programs. Since the US sanctions are discussed in other chapters extensively, we shall not go into details. However, it should be noted that the most remarkable part of the US unilateral sanctions is their application to non-US citizens or companies, or so-called "secondary sanctions."

Secondary sanctions were authorized by the National Defense Authorization Act for Fiscal Year of 2012 (NDAA2012). ${ }^{56}$ This act allowed the Office of Foreign Asset Management (OFAC) of the US Treasury to cut off the businesses of non-US citizens or companies from the US market. When a non-US citizen or company is found in trading with entities on the sanctions blacklist, the OFAC can take a range of measures, from limiting their commercial activities to imposing a total prohibition in the US market. In order to delist from the secondary sanctions list, the non-US citizen or company must pay a large sum of settlement (see Table 10.1). ${ }^{57}$

US citizens and companies are already under the jurisdiction of the US sanctions, but the secondary sanctions measures could be a threat to almost all citizens and companies in the world because the US market is much larger and more profitable than trade with Iran. The only entities that could continue trading with Iran were a few small- and medium-sized companies that had no stake in the US market.

Table 10.1 Settlements paid to the US Treasury

\begin{tabular}{lll}
\hline Year & Financial Institutions & Settlement \\
\hline 2012 & HSBC Bank Financial Services & $\$ 1,256,000,000$ \\
2012 & Standard Chartered Bank Financial Services & $\$ 667,000,000$ \\
2012 & ING Bank N.V. Financial Services & $\$ 619,000,000$ \\
2013 & Bank of Tokyo-Mitsubishi UFJ Financial Services & $\$ 259,000,000$ \\
2014 & BNP Paribas S.A. Financial Services & $\$ 8,960,000,000$ \\
2015 & Commerzbank AG Financial Services & $\$ 258,000,000$ \\
\hline
\end{tabular}

Source: US Treasury 
In addition to the secondary sanctions, the US has another extremely effective measure to implement its unilateral sanctions: the US dollar as international currency. When Iranian individuals and entities conduct economic transactions with foreign partners, Iranians generally use the US dollar as the currency to pay and settle their debts..$^{58}$ Even if the transaction has taken place between an Iranian entity and a non-US citizen or entity, the financial transaction must usually go through corresponding banks in the jurisdiction of the United States. The US unilateral sanctions, which are only effective within its jurisdiction, have a wider impact on transactions between non-US citizens and Iranian individuals or entities because they can intervene the transaction when it goes through corresponding banks in the US. Since the US dollar is the international currency and many foreign banks have branches and accounts under the jurisdiction of the United States, the US has a lot of power to control such transactions. ${ }^{59}$

\section{Importance of EU unilateral sanctions}

When we discuss unilateral sanctions, it is often the US sanctions that are referred to. However, unilateral sanctions measures taken by the European Union have also had a significant impact on the behavior of Iran. The Iranian economy, especially its oil exports, depends heavily on the European market. The oil embargo measures taken in 2012 had a significant impact on Iran's acquisition of foreign currencies. EU regulations also have a strong influence on the financial transactions of Iranian entities, largely due to its control over the SWIFT (Society for Worldwide Interbank Financial Telecommunication) messaging services. SWIFT provides an international standard for interbank message services, so that if EU regulations order SWIFT, whose headquarters is in Brussels, to cut off Iranian financial institutions from its network, it must comply with such regulations. Without SWIFT messaging services, it would be extremely inconvenient for Iranian banks to transfer funds to and from foreign banks. ${ }^{60}$

In addition to imposing an oil embargo and cutting Iranian banks off from SWIFT, the EU has also banned providing insurance services to vessels carrying Iranian oil or cargo. Regarding maritime insurance, the EU has traditionally been competitive in the international insurance market. There are large European insurance corporations and associations that offer such insurance, such as Lloyd's and BP shipping, as well as major reinsurance companies such as Munich-Re in Europe. Maritime shipping entails a certain risk of accident, which is the responsibility of the operators of vessels, and it would be unwise to travel without insurance. The EU insurance ban was, therefore, very effective in limiting the ability of Iran to export its oil to international customers. ${ }^{61}$

Unlike US unilateral sanctions, which are based on domestic legislation and Executive Orders, EU sanctions are based on UNSCRs. Most of the EU sanctions were justified as regional/national implementation of the measures called upon by the resolutions. In other words, the EU sanctions were designed to complement the UN sanctions to improve their effectiveness, while the sanctions of the US are 
not intended to enhance the effect of UNSCRs but to impose its will to change Iranian behavior. ${ }^{62}$

\section{Nuclear negotiations and UNSCR 2231}

Shortly after the implementation of the US National Defense Authorization Act (NDAA) and a series of EU regulations in 2012, the Iranian economy faced a severe downturn and the population became frustrated at the lack of effective measures to counter such economic difficulties. The Ahmadinejad government instantly responded to the crisis by printing more money, which inevitably invited high inflation and imposed further economic hardship on the citizens in Iran. In addition to the fear and hatred generated by the oppression of the "Green Movement" after the 2009 presidential election, the 2013 election resulted in a landslide victory for Hassan Rouhani, a moderate conservative who promised to restart negotiations with the P5+1 (in UN language, the EU3 +3) and lift the sanctions. ${ }^{63}$

\section{Nuclear negotiations}

Rouhani wasted no time in beginning negotiations with the P5 +1 as soon as he was inaugurated to the presidency. The change of government has marked a significant change in the attitude of Iran. While the government has claimed that Iran is a party to the Treaty of Non-Proliferation (NPT) so that it can retain the right to peaceful use of nuclear technology, it has pledged not to engage in militaryrelated activities. Meanwhile, the position of the United States, the archenemy of Iran since the revolution of 1979, has changed as well. President Barack Obama, who was awarded the Nobel Peace Prize for announcing his efforts to achieve a "world without nuclear weapons," saw the change of government in Iran as an opportunity to realize a nuclear-free world through negotiation. He, together with Secretary of State John Kerry, made negotiations with Iran his administration's priority.

Four months after Rouhani's inauguration, the P5+1 and Iran agreed to the Joint Plan of Action (JPOA) in November 2013, and implemented it in January 2014, as an interim agreement for further engagement in negotiations. ${ }^{64}$ The JPOA stipulated that Iran should halt enrichment of uranium more than 5\%, accept inspection and monitoring by the IAEA, and refrain from new installation of centrifuges. In return, Iran could resume exporting oil worth up to \$7 billion (USD), and the sanctions on civil aviation parts and automobiles would be suspended temporarily. Although it was not a comprehensive deal, the conclusion of JPOA was extremely useful in helping the Rouhani government to build trust with the US and other negotiating partners and in helping the Iranian people to feel some hope of relief from the sanctions and the dire economic situation. The deal was also important in convincing hardline politicians, including the Supreme Leader Khamenei, that negotiating with the P $5+1$ could save the Iranian economy while maintaining the Iranian interest in developing nuclear technology for peaceful purposes. It is important to note that Iran has never left the NPT, unlike North 
Korea, and that it has maintained its position that the Iranian nuclear program was developed exclusively for peaceful purposes, though it was later revealed that Iran had attempted to develop military nuclear devices until 2009 at the latest. ${ }^{65}$

The follow-up negotiations continued for another year and a half to hammer out the details of the relief from the sanctions and Iran's obligations to limit its nuclear activities. While the negotiations took place between the P5 +1 , under the chairmanship of the European Union High Representative of the Union for Foreign Affairs and Security Policy, and Iran, the most important decisions were made in the bilateral negotiations between Iran and the United States. For 16 consecutive days, Foreign Minister of Iran Zarif and Secretary of State Kerry sat down together and conducted bilateral talks before concluding the negotiations. ${ }^{66}$

The negotiations were supposed to be finalized by the end of June 2015, but an extension for an additional two weeks was given because the negotiations were solely focused on the nuclear issues, and other issues, including missile development and the arms embargo, were not fully discussed. The negotiators realized that there had been a misunderstanding of the consequences of the sanction relief by the end of the negotiations. Iran demanded that all UNSCRs related to sanctions against Iran be lifted as part of the sanction relief, and Iran and the United States had reached an agreement. However, Kerry, the chief negotiator for the US, believed that the termination of the UNSCRs would only be effective regarding the nuclear issues, and that the issues related to missile development and the arms embargo would remain, while the Iranian negotiator, Zarif, believed that termination of the UNSCRs would resolve all the issues. This misunderstanding was revealed when the Russian chief negotiator, Ryabkov, pointed out that Russia might be able to export arms to Iran after lifting all the UNSCRs. Kerry realized that this would make it impossible for the US Congress and public to accept the agreement if the restrictions on missile development and the arms embargo were lifted. Thus, the issues of missile development and the arms embargo are listed in the "statement" rather than the operational clauses of the UNSCR $2231 .^{67}$

\section{UNSCR 2231 (2015)}

UNSCR 2231 (2015) ${ }^{68}$ endorses the Joint Comprehensive Plan of Action (JCPOA), the agreement between the P5 +1 and Iran. The JCPOA allowed Iran to have 5,060 centrifuges for the enrichment of uranium and 1,044 centrifuges for non-enrichment purposes; to allow it to possess $300 \mathrm{~kg}$ of low enriched uranium (LEU), reduced from $10,000 \mathrm{~kg}$; to allow it to redesign the Arak heavy water reactor; and to allow it to conduct development of centrifuge technologies with a maximum of 30 centrifuges. The sanctions imposed by the UN and EU would be lifted (with some exceptions to arms exports and human rights violations) and the secondary sanctions of the United States would be suspended, while the primary sanctions (subject to US citizens and entities) would remain in place. Meanwhile, Iran was required to accept inspections based on the Additional Protocol by the IAEA with a 24-day notice; constant monitoring, from uranium mining to reprocessing; and a 
requirement to provide information regarding Possible Military Dimension (past activities related to developing nuclear weapons technologies). ${ }^{69}$

\section{(1) Snap back}

One of the key elements of the JCPOA was the concept of "snap back." Snap back is a built-in mechanism to force participant States to comply with the JCPOA. If there is a significant nonperformance of commitments under the JCPOA, any participating States must report it to the Security Council. The Security Council shall then discuss a draft resolution on whether to continue terminating the previous resolutions related to the sanctions against Iran, namely 1696, 1737, 1747, 1803, 1835, and 1929. If the Security Council does not adopt the draft resolution (either by veto or lack of a 9-vote majority), then the previous sanctions will be reinstated in 30 days. $^{70}$

Although snap back is designed to apply for nonperformance of commitments by all participating States, it is, in effect, only possible to apply it to Iran's nonperformance. If there is a violation, the consequence is to reinstate previous sanctions alone, which means that only Iran would be the target of punishment and there would no punishment for nonperformance of P5 +1 States. The unilateral withdrawal from the JCPOA and the reinstatement of national sanctions under the Trump Administration can be interpreted as a violation of the JCPOA or a violation of UNSCR 2231, but there is no effective means to punish the United States. Iran is very unlikely to become a member of the Security Council, but the P5 States have permanent seats and a veto, so they have the decisive power to snap back. The design of the snap back mechanism requires only one P5 State to invoke the process, so if the United States demands a snap back against the nonperformance of Iran, it can certainly deliver the result. This raises a tricky question, since the Trump Administration has not taken this path and has unilaterally withdrawn from the JCPOA without much consideration for this action's consistency with UNSCR 2231.

\section{(2) Missile restrictions}

As discussed earlier, one of the awkward elements of UNSCR 2231 was the continuation of sanctions without calling them "sanctions" but rather "restrictive measures" on missile development and the arms embargo. Annex B of UNSCR $2231^{71}$ is labeled not as "restrictive measures," but as a "statement," in order to soften the image of the measure and imply that these are not measures of enforcement under Chapter VII of the UN Charter but rather voluntarily agreed-upon arrangements between the P5 + 1 and Iran. The "statement" was a de facto continuation of sanctions on activities other than nuclear. Nevertheless, the language used in this "statement" is rather weak compared to that of the previous resolutions.

For missile activities, the "statement" reads as follows:

Iran is called upon not to undertake any activity related to ballistic missiles designed to be capable of delivering nuclear weapons, including launches 
using such ballistic missile technology, until the date eight years after the JCPOA Adoption Day or until the date on which the IAEA submits a report confirming the Broader Conclusion, whichever is earlier (italics added for emphasis). ${ }^{72}$

Iran is only "called upon," instead of "shall," not to undertake missile activities, which means that the statement is not a legally binding restriction, and it leaves room for Iran to decide whether to comply with this provision. It is also notable that the types of ballistic missiles subject to this sentence are limited to missiles "designed to be" capable of delivering nuclear weapons. This suggests that any conventional missiles that may be capable of delivering nuclear weapons, but that were not intentionally designed to carry them, are outside of the scope of this sentence. Iran has resumed its missile activities - it has launched 32 missiles since the adoption of UNSCR 2231 until February 2019 including Space Launch Vehicles - but it claimed that it did not violate UNSCR 2231 because these missiles and space launchers were not specifically "designed to be capable" of carrying nuclear weapons. ${ }^{73}$

\section{(3) Sunset clauses}

The "statement" in UNSCR 2231 also specifies that these restrictive measures will last only for a limited time. Regarding missile development, the clause that calls upon Iran not to undertake missile activities is effective for only eight years from the JCPOA Adoption Day (90 days after the adoption of UNSCR 2231, which was on October 18, 2015). ${ }^{74}$ Regarding the arms embargo, it is only effective for five years from the Adoption Day. ${ }^{75}$ The sunset clause also applies to nuclear activities and other measures. For example, the snap back arrangement can only be effective for ten years, so that there will be no snap backs after $2025 .^{76}$ The cap on the number of centrifuges at the Natanz site for enrichment and the restriction on centrifuge research will be lifted in ten years, all restrictions on nuclear activities will be lifted in 15 years, and the IAEA inspections based on the JCPOA will also expire in 20-25 years. ${ }^{77}$ These "sunset" arrangements in UNSCR 2231 were heavily criticized by the Republicans and those who opposed the Iran deal in the United States, including President Trump. ${ }^{78}$ Although the JCPOA also obliges Iran to adopt the additional protocol before the end of the IAEA inspection period, the sunset clause was considered a bridge to transform Iran into a normal party of the NPT and a Member State of the IAEA. ${ }^{79}$ However, there was a widespread image that Iran could do whatever it wished after the "sunset" and the opponents of the JCPOA believed that Iran would certainly resume its nuclear weapons program.

Since the JCPOA allows Iran to conduct limited nuclear activities, there must be measures to control the flow of goods and items related them. The JCPOA has set up a so-called "procurement channel" to monitor and control the nuclearrelated items that Iran would procure from outside its borders ${ }^{80}$ However, Iran might not procure items exclusively from JCPOA participating States, so there 


\section{Kazuto Suzuki}

must be an enforceable measure through the mandate defined by the Security Council. Thus, UNSCR 2231 contains a clause that requires that all States exporting nuclear-related items to Iran to submit their documents to the Security Council and to work together with the Joint Commission. Although the "procurement channel" was set up by the Security Council, the application of this channel was not as extensive as one might think due to the lack of certainty regarding the future of the JCPOA (as of December 2018, 42 proposals had been processed, 28 had been approved, four disapproved, nine had been withdrawn, and one was under review $)^{81}$ and reinstatement of sanctions by the United States, especially after the presidential election in 2016.

\section{What made it possible for Iran to change?}

The JCPOA and UNSCR 2231 were certainly major achievements in the history of sanctions. In the past, UN sanctions may have led to the change of regime in Apartheid South Africa or the change in the behavior of the Sudanese government with regard to the Darfur conflict, but the sanctions on Iran highlighted an explicit case of sanctions having a direct effect on a State's change of behavior, and sanctions relief was on the agenda of the negotiations for the settlement of the issue..$^{82}$

What lessons could we learn from the experience of sanctions against Iran and the following negotiations? What made the change possible? Could we apply those lessons to other sanctions, or was the effect unique to the case of Iran? There are three lessons that we can learn from the experience of adopting sanctions against Iran.

\section{Coordinated $U N$ and unilateral sanctions}

First, we must consider the balanced and coordinated mix of UN and unilateral sanctions against Iran. As discussed earlier, UN sanctions were heavily criticized after the implementation of sanctions against Iraq that led to the discussion comprising the three processes of the sanctions review: Interlaken, Bonn-Berlin, and Stockholm processes. These processes redefined UN sanctions as "targeted sanctions" or "smart sanctions," which limited the sanctions to a narrow scope on specific items and designated individuals and entities. The main purpose of "targeted sanctions" was to avoid inflicting the effect of sanctions on the general public. The intent of the "targeted sanctions" was primarily humanitarian, and the effectiveness and eventual consequences of sanctions were secondary. The "targeted sanctions" could constrain the illicit activities of the targeted State, but there may still be possibilities of evasion of the sanctions, which could undermine their effectiveness. Although the UN established a Panel of Experts to discover and close such loopholes, the UN sanctions could still have less impact if the target State conspired to capitalize on those loopholes and continue its illicit activities. In other words, the impact of UN sanctions on the decision-making process of the target State has limits. The decision makers in the target country might consider 
finding methods of evading the sanctions rather than changing their behavior and halting their illicit activities.

However, it is wrong to conclude that the UN sanctions were ineffective. In the case of Iran, Foreign Minister Zarif strongly demanded that the UN sanctions be lifted during the negotiations not only because it was a matter of national pride and recognition but also because lifting the designations of many Iranian economic entities would release frozen funds and allow access to dual-use items that could be used for nuclear and missile activities. The UN sanctions were also quite effective at halting, or at least delaying, nuclear and missile activities when "choke-point" items were strongly controlled. ${ }^{83}$ The "choke-point" items were the items that Iran could not produce domestically and could only acquire from foreign markets. If these "choke-point" items were effectively controlled and their export to Iran were prevented, it would have a significant effect on Iran's illicit programs. However because of the importance of "choke-point" items for its illicit programs, Iran would desperately seek the ways around the sanctions.

It is, therefore, important to have alternative means to put pressure on the target. In the case of Iran, the means took the form of unilateral sanctions, especially by the United States and the EU. These sanctions were extremely effective at changing the behavior of Iran. Economic pressure forced the Ahmadinejad Administration to respond to them, which eventually left the Iranian economy in turmoil. ${ }^{84}$ Such economic difficulties changed the minds of the people who had voted for Rouhani in the 2013 presidential election. It is also important to note that the US and EU unilateral sanctions were based on different legal justifications. The EU sanctions were based on UNSCRs, whereas the US sanctions were based on domestic legislation and Executive Orders. The EU sanctions, therefore, followed the guidelines of the sanctions derived from the sanction reviews on "targeted sanctions," including humanitarian aspects, but the US sanctions focused more on national strategic issues. ${ }^{85}$ In fact, the US sanctions also exempted humanitarian items and activities, but the effect of its secondary sanctions, especially the sanctions on financial transactions, made it difficult to deliver humanitarian aid and support to Iran.

By examining the combination of UN and unilateral sanctions, it can therefore be found that there should be clear and attainable common objectives. The success of the sanctions against Iran hinged on the fact that the UN and States exercised unilateral sanctions and united to achieve the same goal: restricting the nuclear activities of Iran and preventing it from having nuclear weapons and delivery systems. It is also important to employ both UN and unilateral sanctions. The UN sanctions, on the one hand, provide legitimacy for unilateral sanctions and they cover almost all the States that could have economic relationships with Iran. The unilateral sanctions, on the other hand, complement the UN sanctions and impose effective pressure on Iran.

\section{Nature of the regime}

The other lesson that can be learned from the sanctions against Iran was that they were successful because there was potential for changing the leadership and its 


\section{Kazuto Suzuki}

policies. Although Iran's regime was born out of the Islamic Revolution in 1979, and it has been driven by clerics and based on Islamic law, it also has a republican system. ${ }^{86}$ The mixture of theocratic and democratic systems often creates tension in the decision-making process, but at least there is an opportunity for the Iranian people to speak out and vote in the election for candidates who might change the policies. The Guardian Council for protecting the Islamic Revolutionary regime has the power to select candidates, and ultimately the Supreme Leader has a say in any political decisions, but the existence of an electoral system to reflect the voices of the people has significant implications. ${ }^{87}$ The pressure imposed by the sanctions on people's lives has certainly changed the political mood in Iran, and Rouhani, a moderate candidate who promised to negotiate the lifting of the sanctions, was elected through the electoral system. It is also important to remember that the presidential election in 2009 was believed to have been rigged and controlled by conservative politicians to reject reformist candidates and ended in the popular uprising known as the "Green Movement," which was harshly suppressed by the regime. The experience of the 2009 election made the conservative politicians, including the Supreme Leader, hesitate to reject Rouhani's platform for negotiating with the enemies. ${ }^{88}$

In comparison with dictatorial regimes such as North Korea, the nature of the Iranian regime is quite important. Sanctions are more effective and successful if there is a political system that allows the people's voice to be reflected in the decision-making process. In other words, it is difficult to change the behavior of target States by putting pressure on the economic and social lives of ordinary people. If sanctions target only political and economic elites by prohibiting luxury goods, it may be possible to avoid sanctioning ordinary people, but as discussed previously, the effectiveness of targeted sanctions may be limited. Thus, it can be said that the success of sanctions depends on the nature of regimes.

\section{Coordination among major powers}

The third aspect of the success of the sanctions against Iran was that there was a commitment made by the major powers, especially the Permanent Members of the Security Council. The major powers shared the view that the sanctions against Iran should encourage a change in its behavior rather than punish the country. The major powers can best control items that are related to nuclear and missile activities, and they are also important players in the international trade in goods that Iran could export to gain foreign currency. The implementation of the unilateral sanctions of the US, especially the secondary sanctions, was carried out by many major countries, including Japan, South Korea, and India, not only out of fear of them but also with a shared understanding of the necessity of putting pressure on Iran to change its behavior.

It is also true that the nuclear negotiations with Iran and the JCPOA were possible because of the change in the attitude of the United States. The Obama Administration defined its strategic goal as a "nuclear free world," and the nuclear issue with Iran was its first priority. Even though traditional allies of the United States, 
such as Israel and Saudi Arabia, were vehemently opposed to the negotiations and the JCPOA, the Obama Administration decided to move forward with negotiations with Iran. ${ }^{89}$ The Obama Administration also defied domestic resistance to the JCPOA. There was strong opposition from various groups that believed that the JCPOA would allow Iran to maintain nuclear capabilities, which could lead to the development of nuclear weapons in the future and possibly lead to a "nuclear domino effect" in the Middle East. Despite such opposition, the Obama Administration went through the congressional process and implemented the JCPOA..$^{90}$ The strong commitment of the US was the reason the negotiation was successful, but this level of commitment cannot be seen in other administrations, including the current Trump Administration.

\section{UNSCR 2231 and the Trump Administration}

Although UN sanctions successfully brought Iran to the negotiating table and concluded a nuclear deal (JCPOA), the euphoria of the deal was short lived. President Trump, one of whose campaign promises was to abolish the JCPOA and reimpose sanctions on Iran, was elected. Although some of the staff in his cabinet tried to stop him from declaring his withdrawal from the agreement based on concerns over the damage it might cause to relationships with allies as well as its credibility, President Trump declared withdrawal from the JCPOA in May 2018, ${ }^{11}$ after firing some of his staff, including Secretary of State Rex Tillerson, National Security Advisor H.R. McMaster, and National Economy Advisor Gary Cohn.

Secretary of State Mike Pompeo announced the New Iran Strategy on May 21, 2018, which contained 12 points outlining demands on Iran, including declaration of a full account of the military dimension of the nuclear program, cessation of uranium enrichment, granting full access to IAEA inspections, ending the proliferation of ballistic missiles, ending support for militias like Hizballah and Houthis, refraining from involvement in Yemen and Syria, and refraining from threatening Israel. ${ }^{92}$ These demands, although they reflected the US policy against Iran on one way or another, were too farfetched to attain only by reinstating the sanctions. If the demands of the sanctions are not realistic and there are not enough incentives for Iran to comply, Iran might decide take measures outside of diplomatic solutions. At this moment, Iran is still complying with the JCPOA, as well as cooperating with the other P5 +1 participating States. The European States are trying hard to maintain the JCPOA framework to ensure that Iran will not take any measures to resume its military nuclear program, but there is no guarantee that the pressure from the reinstated US sanctions will not provoke Iran to engage in armed conflict.

However, it is important to note that the US unilateral declaration of withdrawal from the JCPOA does not mean that the obligations under UNSCR 2231 have disappeared. UNSCR 2231 is still legally binding under Chapter VII of the UN Charter, and all provisions of the JCPOA are still valid. As discussed earlier, neither the JCPOA nor UNSCR 2231 contains any measure to punish the $\mathrm{P} 5+1$ participating States if there is nonperformance under them. After the 
reinstatement of sanctions against Iran, the oil market surged due to fears that the oil embargo could constrict the oil supply in the global market, and the Trump Administration immediately took a measure to allow eight countries to import oil from Iran: Japan, South Korea, China, Taiwan, Italy, Greece, India, and Turkey. These eight countries were traditional importers of Iranian oil, so Iran was permitted to maintain its exports to these countries for six months, from November 2018 to April 2019; however, it is uncertain whether these exceptions to the sanctions will continue in the future.

The change of US policy toward Iran will certainly continue to jeopardize the success of the sanctions against Iran. However, neither Iran nor any of the other participating States are willing to give up on the possibility that the JCPOA and UNSCR 2231 can be effective. It seems that Iran is patiently waiting for the Trump Administration to come to an end and that it is expecting that the new US President will find returning to the JCPOA and complying with UNSCR 2231 a more profitable means of ensuring stability in the Middle East than maintaining a hardline approach.

\section{Notes}

* This work was supported by JSPS KAKENHI Grant Number 16H01982.

1 John Cassidy, "The Iran Deal Is a Victory for Reason and Economic Sanctions," New Yorker (September 3, 2015), available at <www.newyorker.com/news/john-cassidy/ the-iran-deal-is-a-victory-for-reason-and-economic-sanctions $>$.

2 Joint Comprehensive Plan of Action, Vienna (July 14, 2015), available at $<$ www.state. gov/documents/organization/245317.pdf>.

3 "Remarks by President Trump on the Joint Comprehensive Plan of Action," (May 8, 2018), available at <www.whitehouse.gov/briefings-statements/remarks-presidenttrump-joint-comprehensive-plan-action/>.

4 EU3 (UK, France, and Germany) and 3 (the rest of the Permanent Members of Security Council: the US, China, and Russia). UN documents use "EU3+3," but this group is commonly known as the "P5+1," so "P5+1" will be used hereafter.

5 Jeremy Matam Farrall, United Nations Sanctions and the Rule of Law (2009).

6 Charter of the United Nations, Article 39.

7 Charter of the United Nations, Article 40.

8 U.N. Doc. S/RES/1696 (2006).

9 Charter of the United Nations, Article 40.

10 Charter of the United Nations, Article 41.

11 Ibid.

12 U.N. Doc. S/RES/661 (1990).

13 U.N. Doc. S/RES/687 (1991).

14 Enrico Carisch, Loraine Rickard-Martin, and Shawana R. Meister, The Evolution of UN Sanctions: From a Tool of Warfare to a Tool of Peace, Security and Human Rights (2017), pp. 31-32.

15 Ibid., pp. 184-188.

16 Ibid., pp. 191-193.

17 The Watson Institute for International Studies, Brown University, Targeted Financial Sanctions: A Manual for Design and Implementation-Contributions from the Interlaken Process(2001), availableat $<$ www.eda.admin.ch/dam/eda/en/documents/aussenpolitik/ internationale-organisationen/Handbuch-zu-gezielten-Finanzsanktionen_EN.pdf $>$.

18 Ibid.

19 Ibid. 
20 Michael Brzoska, Design and Implementation of Arms Embargoes and Travel and Aviation Related Sanctions: Results of the "Bonn-Berlin Process" (2001), available at $<$ www.smallarmssurvey.org/fileadmin/docs/L-External-publications/2001/2001\%20

21 Ibid. BICC\%20BonnBerlin\%20process.pdf $>$.

22 Ibid.

23 Peter Wallensteen, Carina Staibano, and Mikael Eriksson eds., Making Targeted Sanctions Effective: Guidelines for the Implementation of UN Policy Options - Results from the Stockholm Process on the Implementation Targeted Sanctions (2003), available at $<\mathrm{https}$ ://pcr.uu.se/digitalAssets/653/c_653672-1_1-k_final_report_complete.pdf $>$.

24 Ibid.

25 Ibid.

26 International Institute for Strategic Studies, Nuclear Black Markets: Pakistan, A.Q. Khan and the Rise of Proliferation Networks: A Net Assessment (2007).

27 Gareth Porter, “The Iran Nuclear 'Alleged Studies' Documents: The Evidence of Fraud," Middle East Policy, Vol. 17, No. 4 (2010), available at <www.mepc.org/ iran-nuclear-alleged-studies-documents-evidence-fraud $>$.

28 "Communication Dated 26 November 2004 Received from the Permanent Representatives of France, Germany, the Islamic Republic of Iran and the United Kingdom Concerning the Agreement Signed in Paris on 15 November 2004," International Atomic Energy Agency, INFCIRC/637 (November 26, 2004).

29 Daniel H. Joyner, Iran's Nuclear Program and International Law: From Confrontation to Accord (2016), pp. 27-36.

30 Implementation of the NPT Safeguards, Board of Governors of International Atomic Energy Agency, GOV/2006/38 (June 8, 2006). Agreement in the Islamic Republic of Iran, available at $<$ www.iaea.org/sites/default/files/gov2006-38.pdf $>$.

31 Fourteen member States were in favor, and one member state (Qatar) was against it. U.N. Doc. S/RES/1696 (2006).

32 Implementation of the NPT Safeguards Agreement in the Islamic Republic of Iran, Board of Governors of International Atomic Energy Agency, GOV/2006/53 (August 31, 2006).

33 Ibid., GOV/2006/64 (November 14, 2006).

34 Ibid.

35 "Communications Received from Certain Member States Regarding Guidelines for the Export of Nuclear Material, Equipment and Technology," International Atomic Energy Agency, INFCIRC/254/Rev.8/Part 1a (March 20, 2006); and "Communications Received from Certain Member States Regarding Guidelines for Transfers of Nuclearrelated Dual-use Equipment, Materials, Software and Related Technology," International Atomic Energy Agency, INFCIRC/254/Rev.7/Part 2a (March 20, 2006).

36 "Communications Received from Certain Member States Regarding Guidelines for Transfers of Nuclear-related Dual-use Equipment, Materials, Software and Related Technology," International Atomic Energy Agency, INFCIRC/254/Rev.7/Part 2a (March 20, 2006), p. 2.

37 U.N. Doc. S/RES/1737 (2006), para. 6.

38 Ibid., para. 12.

39 Kazuto Suzuki, "Kokuren Iran Seisai ni-okeru Kinyu-Seisai ni-tsuite [Financial Sanctions in the Sanctions on Iran]," in Sachiko Yoshimura ed., Kokuren no Kinyu-Seisai: Hou to Jitsumu [Financial Sanctions by UN: Law and Practice] (2018), pp. 214-234.

40 U.N. Doc. S/RES/1737 (2006), para. 19.

41 U.N. Doc. S/RES/1747 (2007).

42 Ibid., para. 5.

43 Afshon Ostovar, Vanguard of the Imam: Religion, Politics, and Iran's Revolutionary Guards (2016). 


\section{Kazuto Suzuki}

44 Frederic Wehrey, Jerrold D. Green, Brian Nichiporuk, Alireza Nader, Lydia Hansell, Rasool Nafisi, and S.R. Bohandy, The Rise of the Pasdaran: Assessing the Domestic Roles of Iran's Islamic Revolutionary Guards Corps (2009).

45 U.N. Doc. S/RES/1803 (2008).

46 Ibid., Annex I, II, III.

47 Slater Bakhtavar, Iran: The Green Movement (2009).

48 U.N. Doc. S/RES/1929 (2010).

49 Ibid., para. 8.

50 Ibid., para. 13.

51 "Communications Received from Certain Member States Regarding Guidelines for Transfers of Nuclear-related Dual-use Equipment, Materials, Software and Related Technology," supra note 36, pp. 1-5.

52 U.N. Doc. S/RES/1929 (2010), para. 21.

53 Ibid., para. 15.

54 Ibid., para. 29.

55 "Final Report of the Panel of Experts Established Pursuant to Resolution 1929 (2010)," U.N. Doc. S/2015/401 (June 2, 2015).

56 National Defence Authorization Act for Fiscal Year of 2012, SEC. 1245. [U.S.C. 8513a], available at <www.treasury.gov/resource-center/sanctions/Programs/ Documents/ndaa_publaw.pdf $>$.

57 OFAC Settlement Agreements 2008-2018 (2018), available at <www.visualofac.com/ resources/settlement-agreements/>.

58 Richard Nephew, The Art of Sanctions: A View from the Field (2018).

59 Juan Zarate, Treasury's War: The Unleashing of a New Era of Financial Warfare (2013).

60 Cornelius Adebahr, Europe and Iran: The Nuclear Deal and Beyond (2017), pp. 56-67.

61 Matthew Moran and Daniel Salisbury, "Sanctions and the Insurance Industry: Challenges and Opportunities," CSSS Occasional Papers 2/2013 (September 2013).

62 Francesco Giumelli and Paul Ivan, "The Effectiveness of EU Sanctions: An Analysis of Iran, Belarus, Syria and Myanmar (Burma)," EPC Issue Paper No. 76 (2013), available at <www.epc.eu/documents/uploads/pub_3928_epc_issue_paper_76_-_the effectiveness_of_eu_sanctions.pdf>.

63 Alireza Nader, "Iran's 2013 Presidential Election: Its Meaning and Implications," RAND Perspective (2013), available at <www.rand.org/pubs/perspectives/PE109. html>.

64 “Joint Plan of Action," (November 24, 2013), available at <www.treasury.gov/ resource-center/sanctions/Programs/Documents/jpoa.pdf $>$.

65 Alireza Nader, Ali G. Scotten, and James Hoobler, "Iranian Domestic Challenges to the Joint Comprehensive Plan of Action," RAND Perspective (2013), available at $<$ www.rand.org/pubs/perspectives/PE218.html>.

66 Chintamani Mahapatra, "US - Iran Nuclear Deal: Cohorts and Challenger," Contemporary Review of the Middle East, Vol. 3, No. 1 (March 2016), pp. 36-46.

67 "Addressing Iran's Ballistic Missiles in the JCPOA and UNSC Resolution," Arms Control Association Issue Brief, Vol. 7, No. 8 (July 27, 2015); Dan de Luce and Colum Lynch, "U.S. and Iran Reach Historic Nuclear Deal," Foreign Policy (July 13, 2015).

68 U.N. Doc. S/RES/2231 (2015).

69 “Joint Comprehensive Plan of Action," (July 14, 2015), available at <www.europarl. europa.eu/cmsdata/122460/full-text-of-the-iran-nuclear-deal.pdf>.

70 U.N. Doc. S/RES/2231 (2015), paras. 11-13.

71 Ibid.

72 Ibid., Annex B, para. 3.

73 Alex Ward, “Trump Says Iran Is Violating the Nuclear Deal: It Isn't," VOX (August 7, 2017). 
74 U.N. Doc. S/RES/2231 (2015), Annex B, para. 3.

75 Ibid., Annex B, para. 5.

76 Ibid., para. 8.

77 Kelsey Davenport, "The Joint Comprehensive Plan of Action (JCPOA) at a Glance," Arms Control Association Fact Sheets \& Brief (May 2018), available at <www. armscontrol.org/factsheets/JCPOA-at-a-glance>.

78 Dinshaw Mistry, “Trump Doesn't Like the Iran Deal's Sunset Provisions: Here's How to Fix That," Washington Post (April 25, 2018).

79 U.N. Doc. S/RES/2231 (2015), Annex A, JCPOA Nuclear C, p. 13.

80 Ibid., Annex A, JCPOA Annex IV 6, pp. 89-92.

81 U.N. Doc. S/2018/1106 (December 11, 2018), available at $<$ https://undocs. org $/ \mathrm{S} / 2018 / 1106>$.

82 Carisch, Rickard-Martin, and Meister, supra note 14.

83 "Final Report of the Panel of Experts Established Pursuant to Resolution 1929 (2010)," supra note 55.

84 Nader Habibi, "The Economic Legacy of Mahmoud Ahmadinejad," Middle East Brief, Brandeis University (June 2013), available at $<$ www.brandeis.edu/crown/publications/ meb/MEB74.pdf>.

85 Tarja Cronberg, Nuclear Multilateralism and Iran: Inside EU Negotiations (2017), pp. 23-26.

86 Asghar Schirazi, The Constitution of Iran: Politics and the State in the Islamic Republic (1998).

87 Mandana Naini, "Iran's Second Chamber? The Guardian Council," The Journal of Legislative Studies (August 2006), pp. 198-222, available at <www.tandfonline.com/ doi/abs/10.1080/13572330600739512>.

88 Hanif Zarrabi-Kashani, “Iran's Green Movement Reminds President Rouhani of 2013 Campaign Promises," Medium (May 9, 2017).

89 Trita Parsi, A Single Role of the Dice: Obama's Diplomacy With Iran (2012).

90 Seyed Hossein Mousavian, Iran and the United States: An Insider's View on the Failed Past and the Road to Peace (2014).

91 "Remarks by President Trump on the Joint Comprehensive Plan of Action," supra note 3.

92 "After the Deal: A New Iran Strategy," Department of State (May 21, 2018), available at $<$ www.state.gov/secretary/remarks/2018/05/282301.htm>. 


\section{Syria \\ The chemical weapons question and autonomous sanctions}

Tatsuya Abe*

\section{Introduction}

This article aims to discuss Syrian chemical weapons and autonomous sanction measures. Regarding Syrian chemical weapons, the international community has witnessed developments in the ongoing civil war, such as the use of sarin in August 2013; the surprising start, and successful conclusion, to the elimination of Syrian chemical weapons; and the further use of toxic chemicals including chlorine, sulfur mustard, and sarin since April 2014. How have the international community and its members approached these issues in the context of autonomous sanction measures? In the first section, the author will outline specific autonomous sanction measures against Syria, including those by the United States (US), the European Union (EU), Japan, and Canada. The draft United Nations (UN) Security Council sanction measures will also be discussed for reference purposes, though they were of a collective nature and did not materialize due to the vetoes by Russia and China. In the second section, a comparative analysis of these autonomous sanction measures will be made by focusing on their purposes and designations. The author will conclude the discussion with short remarks.

\section{Sanction measures}

According to Ronzitti, sanctions may be progressively applied. ${ }^{1}$ How have the international community and its members attempted to address the issues of Syrian chemical weapons through sanction measures? This section will provide an overview of autonomous sanction measures by key States and regional organizations, such as the US, the EU, Switzerland, Japan, and Canada. While draft UN sanction measures were vetoed by Russia and China, it is useful to consider their content for the reference purposes.

\section{The US}

The US has carried out a "Syria sanctions program"" that has been implemented and administrated by the Office of Foreign Assets Control (OFAC) of the Department of the Treasury. The "Syria sanctions program" employs the approaches 
of multiple legal authorities and is composed of Executive Orders issued by the President, statutes passed by Congress, and regulations established by the OFAC. Its main components are eight Executive Orders: E.O. 13338, E.O. 13399, E.O. 13460, E.O. 13572, E.O. 13573, E.O. 13582, E.O. 13606, and E.O. 13608. These orders were issued between 2004-2012 under the authority of statutes such as the International Emergency Economic Powers Act (IEEPA), ${ }^{3}$ the National Emergencies Act (NEA), ${ }^{4}$ the Syria Accountability and Lebanese Sovereignty Act of 2003 (SAA), ${ }^{5}$ and the United Nations Participation Act (UNPA), ${ }^{6}$ with a view to blocking the property and interests in property of the Government of Syria, blocking the property and interests in property of persons, prohibiting transactions or dealings with foreign persons, and prohibiting certain transactions (see Table 11.1). ${ }^{7}$ They are further codified by the OFAC and are supplemented by its regulations. A list of targeted individuals and entities has been updated by the Department of the Treasury. As of May 16, 2017, 405 persons and 82 entities were subject to the "Syria sanctions program." Of them, 291 persons were designated under three Executive Orders, E.O. 13572, E.O. 13573, and E.O. 13582, in the context of the use of chemical weapons.

Table 11.1 List of United States Executive Orders related to the Syrian sanctions program

\begin{tabular}{|c|c|c|}
\hline Executive Order & Legal authorities & Purposes \\
\hline $\begin{array}{l}\text { E.O. } 13338 \\
\text { (May } 11,2004)\end{array}$ & IEEPA, NEA, SAA & $\begin{array}{l}\text { Blocking Property of Certain Persons } \\
\text { and Prohibiting the Export of Certain } \\
\text { Goods to Syria }\end{array}$ \\
\hline $\begin{array}{l}\text { E.O. } 13399 \\
\text { (April 25, 2006) }\end{array}$ & IEEPA, NEA, UNPA & $\begin{array}{l}\text { Blocking Property of Additional Persons } \\
\text { in Connection With the National } \\
\text { Emergency With Respect to Syria }\end{array}$ \\
\hline $\begin{array}{l}\text { E.O. } 13460 \\
\text { (February } 13,2008)\end{array}$ & IEEPA, NEA & $\begin{array}{l}\text { Blocking Property of Additional Persons } \\
\text { in Connection With the National } \\
\text { Emergency With Respect to Syria }\end{array}$ \\
\hline $\begin{array}{l}\text { E.O. } 13572 \\
(\text { April } 29,2011)\end{array}$ & IEEPA, NEA & $\begin{array}{l}\text { Blocking Property of Certain Persons } \\
\text { with Respect to Human Rights Abuses } \\
\text { in Syria }\end{array}$ \\
\hline $\begin{array}{l}\text { E.O. } 13573 \\
\text { (May } 18,2011 \text { ) }\end{array}$ & IEEPA, NEA & $\begin{array}{l}\text { Blocking Property of Senior Officials of } \\
\text { the Government of Syria }\end{array}$ \\
\hline $\begin{array}{l}\text { E.O. } 13582 \\
\text { (August 17, 2011) }\end{array}$ & IEEPA, NEA & $\begin{array}{l}\text { Blocking Property of the Government } \\
\text { of Syria and Prohibiting Certain } \\
\text { Transactions with Respect to Syria }\end{array}$ \\
\hline $\begin{array}{l}\text { E.O. } 13606 \\
\text { (April 22, 2012) }\end{array}$ & IEEPA, NEA & $\begin{array}{l}\text { Blocking the Property and Suspending } \\
\text { Entry Into the United States of Certain } \\
\text { Persons With Respect to Grave Human } \\
\text { Rights Abuses by the Governments } \\
\text { of Iran and Syria via Information } \\
\text { Technology }\end{array}$ \\
\hline $\begin{array}{l}\text { E.O. } 13608 \\
\text { (May } 1,2012 \text { ) }\end{array}$ & IEEPA, NEA & $\begin{array}{l}\text { Prohibiting Certain Transactions With } \\
\text { and Suspending Entry Into the United } \\
\text { States of Foreign Sanctions Evaders } \\
\text { With Respect to Iran and Syria }\end{array}$ \\
\hline
\end{tabular}


In addition to the "Syrian sanctions program," E.O. 13382 is also relevant to Syrian chemical weapons, particularly their production. This Executive Order was issued in June 2005 based on the authority vested in the President under IEEPA with the purpose of implementing an asset freeze and transactions ban on proliferators of Weapons of Mass Destruction (WMD) and their supporters (see Table 11.2). This is a clear indication of early concerns on the part of the US, even before the breakout of the civil war, about the proliferation of WMDs in Syria. A list of targeted individuals and entities has been updated by the Department of the Treasury. As of May 16, 2017, 20 entities had been designated; of them, 14 are believed to be involved in the proliferation of chemical weapons.

\section{The $E U$}

The EU has taken "Restrictive Measures on Syria" that have been implemented by its members. The EU takes an all-inclusive, expansive legislative approach. In accordance with Article 215 of the Treaty on the Functioning of the EU, which provides a legal basis for the interruption or reduction of the EU's economic and financial relations with one or more third countries, a Council decision has identified a list of comprehensive restrictive measures. ${ }^{9}$ If they are not sufficient, another Council decision will be introduced to expand their scope.

In the case of sanction measures against Syria, the original Council Decision 2011/273/CFSP of May 9, 2011, was replaced or amended by subsequent Council Decisions, such as 2011/782/CFSP of December 1, 2011; 2012/739/CFSP of November 29, 2012; and 2013/186/CFSP of April 22, 2013. ${ }^{10}$ The current Council Decision 2013/255/CFSP of May 31, 2013, covers a variety of restrictive measures, such as asset freezes on individuals and entities, including the Syrian central bank; a travel ban on individuals; a ban on the import of arms, crude oil, and petroleum products; a ban on the export of key equipment and technology for the oil and gas industries, luxury goods, and aviation fuel; a ban on trade in goods belonging to Syria's cultural heritage, gold, precious metals, and diamonds; a ban on investment in the Syrian oil industry; a ban on various activities related finance and financial transactions; a ban on cargo flights operated by Syrian carriers; and an obligation to inspect vessels and aircrafts that may be carrying arms. ${ }^{11}$ In terms of the asset freeze and travel ban, a list of targeted individuals and entities may be updated through a Council decision or a Council implementing decision. As of March 19, 2018, 261 persons and 67 entities were subject to asset freezes, and the

Table 11.2 List of United States Executive Orders related to the sanctions against proliferators of weapons of mass destruction

\begin{tabular}{lll}
\hline Executive Order & Legal authorities & Purposes \\
\hline E.O. 13382 & IEEPA & Blocking Property of Weapons of Mass \\
(June 28, 2005) & & $\begin{array}{l}\text { Destruction Proliferators and Their } \\
\text { Supporters }\end{array}$ \\
\hline
\end{tabular}


same 261 persons were also subject to the travel ban. ${ }^{12}$ Of them, 31 persons and ten entities are believed to be involved in the proliferation of chemical weapons.

Furthermore, Council Decision 2014/74/CFSP of February 10, 2014, amended Council Decision 2013/255/CFSP of May 31, 2013, and introduced an exception to the freezing of funds and economic resources of the Central Bank of Syria or Syrian State-owned entities. Part of the funds can be released if they are used for payments or activities related to the OPCW verification mission and the destruction of Syrian chemical weapons. However, Syria refuses to take advantage of this provision.

\section{Switzerland}

Switzerland has taken "Measures against Syria" (Mesures à l'encontre de la Syrie/ Massnahmen gegenüber Syrien) that have been implemented by the State Secretariat for Economic Affairs (SECO). Switzerland also takes an all-inclusive, expansive legislative approach. Specific measures have been issued in separate orders based on the Federal Act on the Implementation of International Sanctions of March 22, 2002. If a specific order is insufficient, another can replace it and expand the scope of the sanction measures.

In the context of Syria, Switzerland issued an order on May 18, 2011, addressing the supply of military equipment and goods used for internal repression. ${ }^{13}$ It was modified slightly by the subsequent orders completely revised by the order of June 8 , 2012, which includes trade restrictions on items such as arms; oil and oil products; technologies for the exploitation and production of oil and natural gas; jet fuel; production of electricity; the equipment, technology, and software for use in surveillance; precious metals and diamonds; luxury goods; and cultural property, as well as an asset freeze, including the restriction of financial activities, and a travel ban. ${ }^{14}$ The list of targeted individuals and entities has been updated by subsequent amendments to the order. As of July 17, 2018, 261 persons and 67 entities were designated by it. ${ }^{15}$

\section{Japan}

Japan has applied existing legislation, the Foreign Exchange and Foreign Trade Act of December 1, 1949, to persons and entities designated by the Ministry of Foreign Affairs. They are subject to a restriction on payment and capital transactions. The original list of targeted persons and entities was made public on September 9, 2011, and it was supplemented four times: on November 22, 2011; March 9, 2012; July 6, 2012; and November 27, 2012. Among the total of 59 persons and 35 entities who have been designated by it, six entities are believed to be involved in the proliferation of chemical weapons. No additional action has been taken by the Japanese authorities since November 2012.

\section{Canada}

Canada has also applied existing legislation, the Special Economic Measures Act of June 4, 1992, ${ }^{16}$ to the situation in Syria. To take concrete actions, the Special 
Economic Measures (Syria) Regulations were adopted on May 24, 2011, in accordance with the relevant provisions of the act. ${ }^{17}$ Based on the regulations, persons in Canada and Canadians abroad are prohibited from dealing in the property of designated persons who are members of the Syrian regime. The regulations have been amended 13 times so far. The scope of sanction measures has been expanded and now includes an arms embargo; asset freeze; export restrictions, such as an export ban on telecommunications monitoring equipment and luxury goods; an import ban on all goods from Syria; a financial prohibition; a technical assistance prohibition; and so on.

In addition, in terms of chemical weapons, the export, sale, supply, or shipment of additional chemical weapons precursors and dual-use technologies to Syria, as well as the procurement of chemical weapons, related equipment, goods, and technology from Syria were prohibited by the two regulations amending the Special Economic Measures (Syria) Regulations on July 5, 2012, and January 29, 2014, respectively. The latter set of regulations accommodated the latest control list agreed upon by the 2013 Australia Group Plenary and implemented the obligation to prohibit the procurement of chemical weapons, related equipment, and goods from Syria under paragraph 20 of UN Security Council Resolution 2118. As of April 20, 2017, 234 persons and 57 entities were subject to the asset freeze and dealing prohibitions. Out of them, 17 persons and 12 entities are believed to be involved in the proliferation of chemical weapons.

\section{The UN}

UN Security Council Resolution 2118 includes a paragraph that obliges all Member States to prohibit the procurement of chemical weapons, related equipment, and goods from Syria. This measure can be categorized as a collective sanction. As mentioned, Canada has taken necessary measures to implement this specific obligation. More powerful collective sanction measures were discussed in late February 2017, when the UK and France tabled draft sanction measures against Syria. ${ }^{18}$ This initiative was taken in response to the conclusion of the OPCW-UN Joint Investigative Mechanism (JIM) that the Syrian government was involved in the use of toxic chemicals as weapons against its own population in three cases. ${ }^{19}$ In reality, however, the draft resolution was not adopted due to negative votes from China and Russia. ${ }^{20}$

The sponsors took a tailor-made approach under Article 41, Chapter VII, of the UN Charter. The draft sanction measures included not only typical elements, such as an asset freeze and travel ban, but also other measures directly relevant to the use of chemical weapons, such as an embargo on chemicals and helicopters. The chemicals that Member States are not allowed to supply, sell, or transfer to designated persons or entities are a combination of those in the Annex on Chemicals of the CWC, or so-called Scheduled Chemicals, and those in the UN official document (S/2017/170), which are identical to the chemicals on the Australia Group list. This was the same approach that was employed when the UN Security Council adopted Resolution 1714 on sanction measures against the DPRK. Resolution 
1714 referred to the UN official document (S/2006/816) that specified items, materials, equipment, goods, and technology related to biological and chemical weapons. They were the same items, materials, equipment, goods, and technology on the Australia Group list at that time. In this regard, the Scheduled Chemicals under the CWC and the Australia Group list may be used in the future as a useful reference. An attached annex identified 11 individuals and ten entities involved in the use and production of chemical weapons in Syria (see Tables 11.3 and 11.4). They were supposed to be subject to these sanction measures.

Table 11.3 List of designated individuals (U.N. Doc. S/2017/172 (February 28, 2017), Annex 1)

\begin{tabular}{|c|c|c|}
\hline \# & Name & Descriptions \\
\hline 1 & AMR ARMANZI & $\begin{array}{l}\text { Director-General of the SSRC/CERS, responsible } \\
\text { for the development and production of chemical } \\
\text { weapons, and the missiles to deliver them, in the } \\
\text { Syrian Arab Republic. }\end{array}$ \\
\hline 2 & $\begin{array}{l}\text { BRIGADIER GENERAL } \\
\text { GHASSAN ABBAS }\end{array}$ & $\begin{array}{l}\text { Head of the branch of the SSRC/CERS ... Involved } \\
\text { in the proliferation of chemical weapons and the } \\
\text { organization of chemical weapons attacks in the } \\
\text { Syrian Arab Republic. }\end{array}$ \\
\hline 3 & $\begin{array}{l}\text { COLONEL MUHAMMAD } \\
\text { BILAL }\end{array}$ & $\begin{array}{l}\text { A senior officer in the Air Force Intelligence Service } \\
\text { of Syria who is associated with the SSRC/CERS. }\end{array}$ \\
\hline 4 & BAYAN BITAR & $\begin{array}{l}\text { Managing Director of . . . the Organization for } \\
\text { Technological Industries (OTI) ... which assists in } \\
\text { the production of chemical weapons for the Syrian } \\
\text { regime. }\end{array}$ \\
\hline 5 & $\begin{array}{l}\text { COL SUHAYL HASAN } \\
\text { AL-HASAN }\end{array}$ & $\begin{array}{l}\ldots \text { a pro-regime militia commander and Syrian Air } \\
\text { Force Intelligence (SAFI) officer . . . involved in } \\
\text { the use of chlorine in those attacks. }\end{array}$ \\
\hline 6 & MG JAMIL HASSAN & $\begin{array}{l}\text { Head of the Syrian Air Force Intelligence (SAFI) and } \\
\text { commander of the SAFI personnel involved in the } \\
\text { chlorine attacks on Talmenes, Qmenas, and Sarmin. }\end{array}$ \\
\hline 7 & $\begin{array}{l}\text { MG SAJI JAMIL } \\
\text { DARWISH }\end{array}$ & $\begin{array}{l}\text {. . a commander of the Syrian Air Force ... } \\
\text { would have allowed chlorine use in his area of } \\
\text { responsibility ... }\end{array}$ \\
\hline 8 & $\begin{array}{l}\text { BG MUHAMMAD } \\
\text { IBRAHIM }\end{array}$ & $\begin{array}{l}\text {. . the deputy commander of the Syrian Air Force's } \\
\text { 63rd Air Brigade at Hamah Airfield at the time of } \\
\text { the Talmenas attack ... }\end{array}$ \\
\hline 9 & BG BADI' MUALLA & $\begin{array}{l}\text {... the commander of the Syrian Air Force's 63rd Air } \\
\text { Brigade ... would have allowed chlorine use in his } \\
\text { area of responsibility ... }\end{array}$ \\
\hline 10 & $\begin{array}{l}\text { MG TALAL SHAFIQ } \\
\text { MAKHLUF }\end{array}$ & $\begin{array}{l}\text { Major General in the Syrian Republican Guard ... } \\
\text { would have coordinated military operations } \\
\text { incorporating chlorine strikes ... }\end{array}$ \\
\hline 11 & MG AHMAD BALLUL & $\begin{array}{l}\text {... As Commander of the Syrian Air and Air } \\
\text { Defense ... would have allowed the regime's } \\
\text { chlorine use. }\end{array}$ \\
\hline
\end{tabular}


Table 11.4 List of designated entities (U.N. Doc. S/2017/172 (February 28, 2017), Annex 1)

\begin{tabular}{|c|c|c|}
\hline \# & Name & Descriptions \\
\hline 12 & $\begin{array}{l}\text { CENTRE D'ÉTUDES ET DE } \\
\text { RECHERCHES SYRIEN } \\
\text { (CERS) }\end{array}$ & $\begin{array}{l}\text { Government entity responsible for developing } \\
\text { and producing chemical weapons, and the } \\
\text { missiles to deliver them, in the Syrian Arab } \\
\text { Republic. }\end{array}$ \\
\hline 13 & EXPERT PARTNERS & $\begin{array}{l}\text { Associated with the SSRC/CERS; acts as a } \\
\text { proxy. }\end{array}$ \\
\hline 14 & BUSINESS LAB & $\begin{array}{l}\text { Associated with the SSRC/CERS, acts as a } \\
\text { front company. }\end{array}$ \\
\hline 15 & INDUSTRIAL SOLUTIONS & $\begin{array}{l}\text { Associated with the SSRC/CERS, acts as a } \\
\text { front company. }\end{array}$ \\
\hline 16 & $\begin{array}{l}\text { NATIONAL STANDARDS \& } \\
\text { CALIBRATION } \\
\text { LABORATORY (NSCL) }\end{array}$ & $\begin{array}{l}\text { Affiliated with, and a subsidiary of, the SSRC/ } \\
\text { CERS. It provides training and support to the } \\
\text { SSRC. }\end{array}$ \\
\hline 17 & $\begin{array}{l}\text { HANDASIEH - } \\
\text { ORGANIZATION FOR } \\
\text { ENGINEERING INDUSTRIES }\end{array}$ & $\begin{array}{l}\text { Associated with the SSRC/CERS; acts as a } \\
\text { front company. }\end{array}$ \\
\hline 18 & $\begin{array}{l}\text { SYRONICS - SYRIAN ARAB } \\
\text { CO. FOR ELECTRONIC } \\
\text { INDUSTRIES }\end{array}$ & $\begin{array}{l}\text { Associated with the SSRC/CERS; acts as a } \\
\text { front company. }\end{array}$ \\
\hline 19 & $\begin{array}{l}\text { MECHANICAL } \\
\text { CONSTRUCTION FACTORY } \\
\text { (MCF) }\end{array}$ & $\begin{array}{l}\text { Associated with the SSRC/CERS; acts as a } \\
\text { front company. }\end{array}$ \\
\hline 20 & $\begin{array}{l}\text { HIGHER INSTITUTE FOR } \\
\text { APPLIED SCIENCES AND } \\
\text { TECHNOLOGY (HIAST) }\end{array}$ & $\begin{array}{l}\text { Affiliated with, and a subsidiary of, the SSRC/ } \\
\text { CERS. It provides training and support to the } \\
\text { SSRC. }\end{array}$ \\
\hline 21 & $\begin{array}{l}\text { ORGANIZATION FOR } \\
\text { TECHNOLOGICAL } \\
\text { INDUSTRIES }\end{array}$ & $\begin{array}{l}\text { A subsidiary of the Syrian Ministry of Defense; } \\
\text { involved in the production of chemical } \\
\text { weapons for the Syrian regime. }\end{array}$ \\
\hline
\end{tabular}

\section{Analysis}

This section will make a comparative analysis of autonomous sanction measures by focusing on 11 individuals and ten entities who were on a list of designation in draft UN sanction measures. This is primarily because all 21 targets have been also designated by the US, the EU, Switzerland, and Canada, and thus can be identified as key persons and entities in the Syrian chemical program. It should also be noted that draft collective sanction measures have enjoyed a certain level of support. ${ }^{21}$ What are the purposes of autonomous sanction measures? What are the features of designation?

\section{Purposes}

Sanction measures have been taken against Syria for two major reasons, depending upon the development of chemical weapons issues: proliferation concerns and reactions to the use of chemical weapons. The use of sarin in August 2013 
drastically changed the landscape of Syrian chemical weapons issues. The intent of sanction measures also changed drastically.

\section{(1) Proliferation concerns}

Until August 2013, when sarin was used on a large scale, autonomous sanction measures were primarily aimed at addressing proliferation concerns. Syria has long been suspected of conducting a chemical weapons program. At least as early as 1989, the United States recognized the danger:

Syria began producing chemical warfare agents and munitions in the mid1980 s, and currently has a chemical warfare production facility. Syria has nerve agents in some weapons systems. Damascus conceals its program; it is quite closely held; and . . . is likely to continue to expand its chemical warfare capability. ${ }^{22}$

An attempt to acquire dual-use chemical agents was revealed in August 1992. A German vessel on the way to Syria was stopped by the authorities in Cyprus. Its cargo included 45 tons of the nerve agent precursor trimethyl phosphite. This was the second half of a shipment from an Indian company. The first half had reached Syria in May. As a result of the investigation by Indian customs authorities, it became clear that the Indian company did not get permission from the government to sell trimethyl phosphite to Syria. ${ }^{23}$ This incident attracted the attention of the international community. The fact that Syria neither signed nor acceded to the 1993 Chemical Weapons Convention (CWC) ${ }^{24}$ also raised suspicion. The center of the proliferation concerns was the Syrian Scientific Studies and Research Centre (SSRC) or Centre D'Etudes et de Recherches Scientifiques (CERS). ${ }^{25}$

In June 2005, more than five years before the uprising of the domestic conflict, the US took the action of issuing E.O. 13382, which was "aimed at freezing the assets of proliferators of weapons of mass destruction and their supporters and isolating them financially" and identified \#12 the Syrian Scientific Studies and Research Centre (SSRC) in its Annex as one of eight entities subject to autonomous sanction measures. ${ }^{26}$ In January 2007, the US added subordinates of the SSRC (\#16 and \#20) pursuant to E.O. 13382, to the sanction list. ${ }^{27}$ Even after the outbreak of domestic conflict in March 2011, the US continued to strengthen autonomous sanction measures. In July 2012, the US added five more entities (\#14, \#15, \#17, \#18, and \#19) to the list, based on E.O. 13382 because they were "designated for acting for or on behalf of Syria's SSRC, the entity responsible for the development of biological and chemical weapons as well as the missiles to deliver them." 28 Two months later, one individual (\#1) was also designated pursuant to E.O. 13382. ${ }^{29}$ At this juncture, Syria ended up acknowledging the possession of chemical weapons. ${ }^{30}$ These autonomous sanction measures illustrated how serious the concerns of the US about the proliferation of WMDs were. ${ }^{31}$ They were not taken in response to a previously internationally wrongful act but aimed at addressing proliferation concerns. As long as the US has no obligation 
to maintain economic relations with Syria, and autonomous sanction measures, as such, are lawful and fully consistent with international law, they may be categorized as retorsion rather than countermeasures. ${ }^{32}$

In the meantime, in December 2011, the EU designated not only \#12 the Syrian Scientific Studies and Research Centre (SSRC) because it "provides support to the Syrian army for the acquisition of equipment used directly for the surveillance and repression of demonstration" but also five other entities (\#14, \#15, $\# 17$, \#18, and \#19), each of which was a "front company for the acquisition of sensitive equipment by the CERS." 33 Canada and Switzerland followed the EU actions and included the same institutions on their sanctions lists in December 2011 and February 2012, respectively. ${ }^{34}$ Canada took measures

in order to respond to the gravity of the situation in Syria, which, in the Governor in Council's opinion, constitutes a grave breach of international peace and security that has resulted, or is likely to result, in a serious international crisis, ${ }^{35}$

while Switzerland cited exactly the same reasons as the EU for designation. ${ }^{36}$ Japan also took autonomous sanction measures against the SSRC and the previously mentioned five SSRC subordinates in December 2011 and November 2012, respectively, "in order to contribute to the international efforts to achieve international peace" and to address the situation in Syria. ${ }^{37}$ It follows that the EU, Switzerland, Canada, and Japan paid careful attention to the SSRC and its subordinates. However, it is not as clear whether their primary concern was the proliferation of WMDs. ${ }^{38}$

\section{(2) Response to the use of chemical weapons}

Since August 2013, the international community has witnessed multiple uses of chemical weapons. Several States and regional organizations have adopted autonomous sanction measures in response to these heinous acts. On August 21, 2013, the use of chemical weapons in Ghouta was reported. The UN mission confirmed that "chemical weapons have been used in the ongoing conflict" and that "the environmental, chemical and medical samples ... provide clear and convincing evidence that surface-to-surface rockets containing the nerve agent Sarin were used . . . in the Ghouta area of Damascus." "39 The UN Security Council condemned "in the strongest terms any use of chemical weapons in the Syrian Arab Republic in particular the attack on 21 August 2013, in violation of international law." ${ }^{40}$

In early March 2015, the EU took autonomous sanction measures. They targeted one individual (\#2) for being "involved in the proliferation of chemical weapons and the organisation of chemical weapons attacks, including in Ghouta in August 2013," another individual (\#4) by pointing out that "[d]ue to his role in the production of chemical weapons, he also shares responsibility for the violent repression against the Syrian population" and his institution (\#21), which "is involved in the production of chemical weapons for the Syrian regime." 41 These 
EU sanction measures were followed by Switzerland. ${ }^{42}$ Since April 2014, further chemical attacks in Syria have been alleged. In response to the allegations, two ad hoc procedures have been established: the OPCW Fact-Finding Mission (FFM) and the OPCW-UN Joint Investigative Mechanism (JIM).

On April 29, 2014, the OPCW Director-General took the initiative and announced the formation of an OPCW FFM in Syria that was mandated "to establish facts surrounding allegations of use of toxic chemicals, reportedly chlorine, for hostile purposes in the Syrian Arab Republic." ${ }^{33}$ The OPCW FFM carried out the investigation and confirmed that a toxic chemical was used as a weapon in the villages of Talmanes, Al Tamanah, and Kafr Zita from April to August 2014. ${ }^{44}$ The UN Security Council expressed deep concern and noted that such use of toxic chemicals as a weapon would constitute "a violation of resolution 2118 and of the CWC." ${ }^{45}$ The allegations of the use of toxic chemicals continued. The OPCW FFM again confirmed that chlorine was used at the Idlib Governorate between March and May 2015, and sulfur mustard was used at Marea in August 2015 and at Um-Housh (or Umm Hawsh) in September 2016, respectively. ${ }^{46}$

The mandate of the OPCW FFM was limited to determining whether chemical weapons had been used. It was not tasked with identifying who had used chemical weapons. Having recognized these deficiencies, in August 2015, the OPCW-UN Joint Investigative Mechanism (JIM)) was established by the Security Council and tasked with determining who was involved in the use of chemicals as weapons. ${ }^{47}$ After examining the information regarding the incidents, the OPCW-UN JIM concluded that barrel bombs filled with chlorine were dropped at Talmenes in April 2014, as well as at Sarmin and Qmenas in March 2015, by a Syrian Arab Armed Forces helicopter, resulting in the release of chlorine, and that sulfur mustard was used at Marea and Umm Hawsh (or Um-Housh) in August and September 2015 , respectively, by ISIL. ${ }^{48}$

On January 12, 2017, the US finally acted, for the first time, in connection with the use of chemical weapons. A total of 18 individuals and six entities were designated. They can be divided into two groups. One group is comprised of Syrian military branches and officials (\#3, \#5, \#7, \#8, \#9, \#10, and \#11). Since they were engaged in the use of chlorine, E.O. 13572 and E.O. 13573 were the legal basis for designation. The other group is comprised of technical personnel and institutions (\#2, \#4, and \#21). They were involved in the production of chemical weapons and therefore designated, pursuant to E.O. 13382.49 On April 4, 2017, another instance of the use of chemical weapons was alleged. According to media reports, the victims seemed to suffer from sarin poisoning. ${ }^{50}$ The OPCW FFM almost immediately began its investigation ${ }^{51}$ and confirmed that sarin was used at Khan Shaykhun. Following this finding by the OPCW FFM, the OPCW-UN JIM concluded that the Syrian Arab Republic was responsible for the release of sarin at Khan Shaykhun in April 2017.52

In the US, the Trump Administration quickly responded to this serious incident. Military actions were taken against the Assad regime two days later. The economic sanction measures were strengthened pursuant to E.O. 13582 by adding 271 SSRC employees to the list. ${ }^{53}$ In July, the EU also designated eight high-ranking 
military officials and eight scientists involved in chemical weapons proliferation and delivery to be included in the sanctions list. $^{54}$ In August, Switzerland took the same action as the EU. ${ }^{55}$ These autonomous sanction measures were taken against the use of chemical weapons. Is there a possibility that they could be categorized as countermeasures? Perhaps there is not. If there is no international obligation to maintain economic relations between Syria and the States or regional organizations that carry out sanction measures, autonomous sanction measures, as such, are lawful and cannot violate international law. Given that the Syrian government used chemical weapons in violation of international law, it may also be difficult to recognize the US, the EU members, Canada, and Switzerland as an "injured State" that is entitled to take countermeasures under the law of state responsibility. This is because they suffered no material damage. In this regard, Article 54 of the ILC Articles on State Responsibility endorses the right of "non-injured States" to take "lawful measures" against a State that has violated international law.

\section{Designations}

Autonomous sanction measures have two dimensions. On the one hand, they can be diverse among States and regional organizations because each sovereign State or regional organization has full discretion in this regard. On the other hand, they tend to be uniform and consistent with each other because collective common actions tend to be more effective than individual ones. This section will discuss the diversity and unity of autonomous sanction measures against Syria by focusing on the targets and timing of the designations.

\section{(1) Unity}

\section{(A) GENERAL TENDENCY}

The previous discussion illustrates the fact that a previous decision by a State or regional organization tends to have an impact on the later decision of another (Tables 11.5-11.7). It goes without saying that the US and the EU have likely played leading roles in designating individuals and entities because they have intelligence information. Their preceding designations have essentially been followed by other States, such as Switzerland and Canada. Japan has partially subscribed to the decisions of the US and the EU.

In 2005, more than five years before the uprising of domestic conflict, the US took the first sanction measures against Syria in the context of proliferation concerns. One of the targets was \#12 the Syrian Scientific Studies and Research Centre (SSRC). ${ }^{56}$ In 2007, the US added two subordinates of the SSRC \#16 the National Standards and Calibration Laboratory (NSCL) and \#20 the Higher Institute of Applied Science and Technology (HIAST) - to the list. ${ }^{57}$ The EU, Japan, Canada, and Switzerland took actions against the SSRC during the period from December 2011 to February 2012..$^{58}$ The EU and Switzerland also added the NSCL and the HIAST in July and September 2014, respectively. ${ }^{59}$ 
Table 11.5 Chronology of designations from June 2005 to July 2013

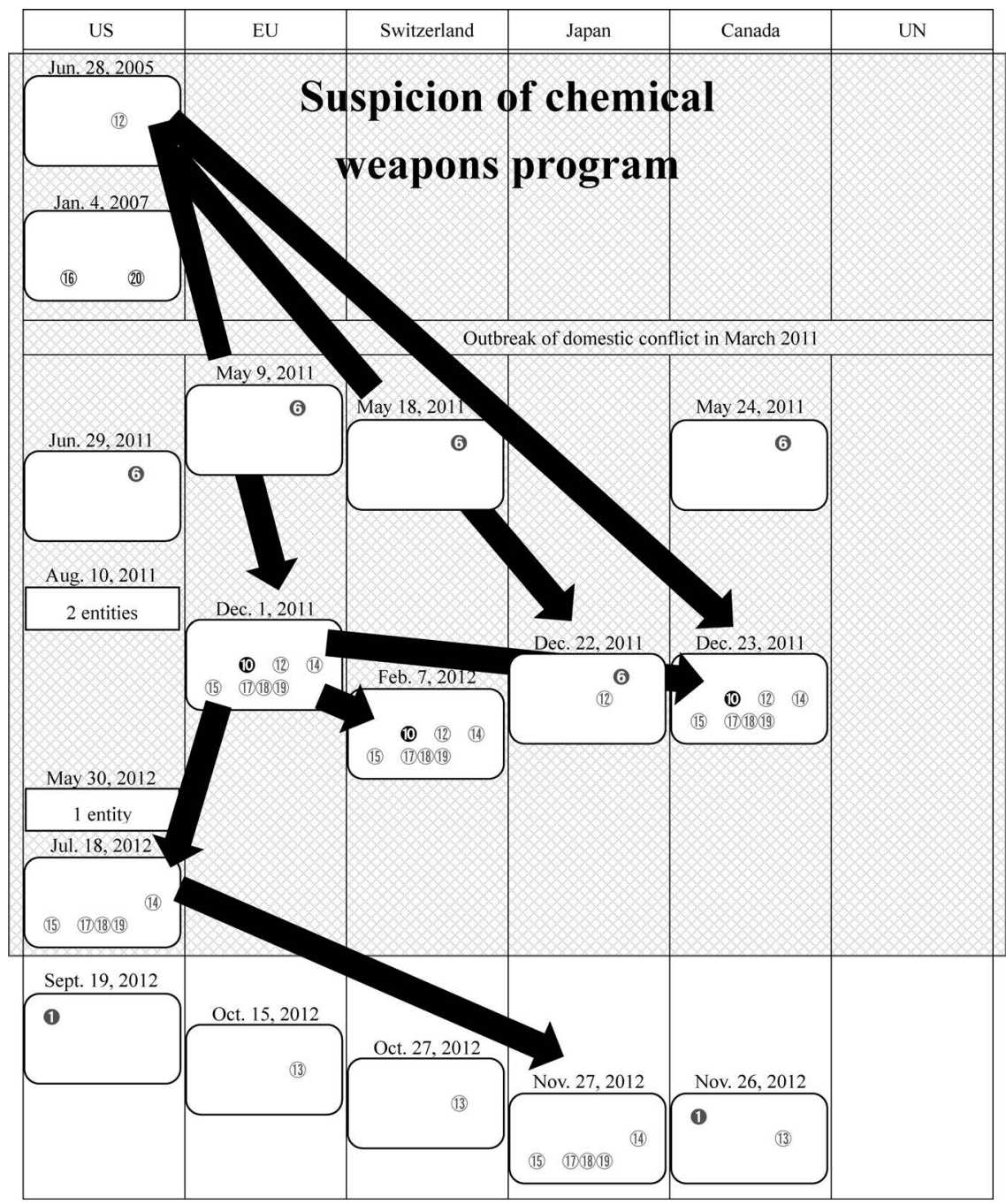

Canada also took autonomous sanction measures against these two entities in April 2017. ${ }^{60}$

In fact, in December 2011, the EU designated not only \#12 the Syrian Scientific Studies and Research Centre (SSRC) but also five other entities - \#14 Business Lab, \#15 Industrial Solutions, \#17 Handasieh - Organization for Engineering Industries, \#18 Syronics - Syrian Arab Co. for Electronic Industries, and \#19 Mechanical Construction Factory (MCF). ${ }^{61}$ Canada and Switzerland followed the EU actions and included the same institutions on their sanctions lists in December 2011 and February 2012, respectively. ${ }^{62}$ Their designations might not be directly relevant to the chemical weapons issues; however, the US added 
Table 11.6 Chronology of designations from August 2013 to July 2016

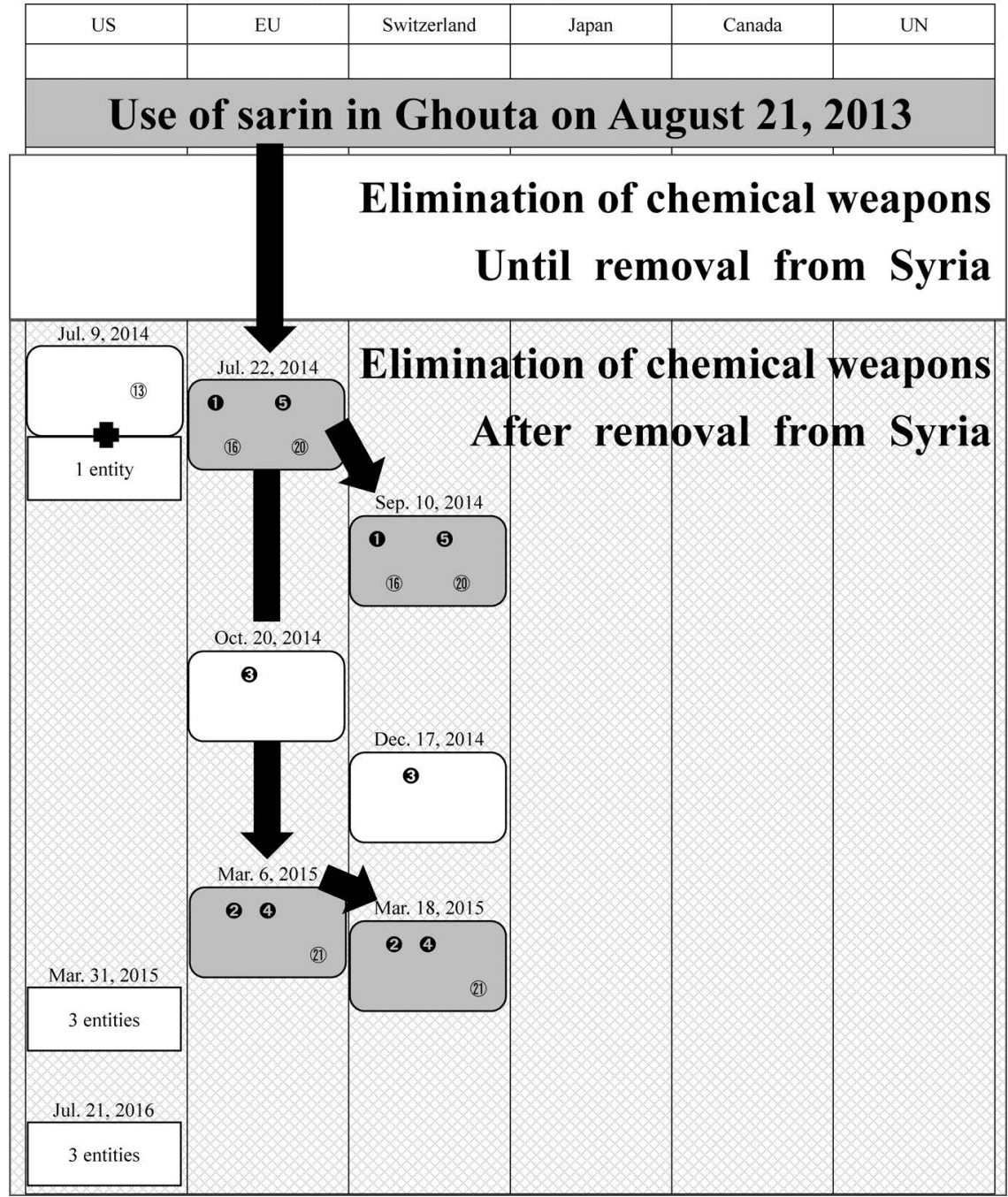

these entities to the sanctions list because of WMD proliferation concerns. ${ }^{63}$ Japan took the same action in November 2012. ${ }^{64}$

In early March 2015, the EU took autonomous sanction measures. They targeted \#2 Brigadier General Ghassan Abbas, \#4 Bayan Bitar, and \#21 the Organisation for Technological Industries (OTI). ${ }^{65}$ Switzerland made the same decision within 12 days. ${ }^{66}$ In January 2017, the US designated 18 individuals and six entities. They included the targets that had been designated by the EU and Switzerland as well as new targets, such as \#7 Major General Saji Jamil Darwish, \#8 Brigadier General Muhammad Ibrahim, \#9 Brigadier General 
Table 11.7 Chronology of designations from August 2016 to August 2017

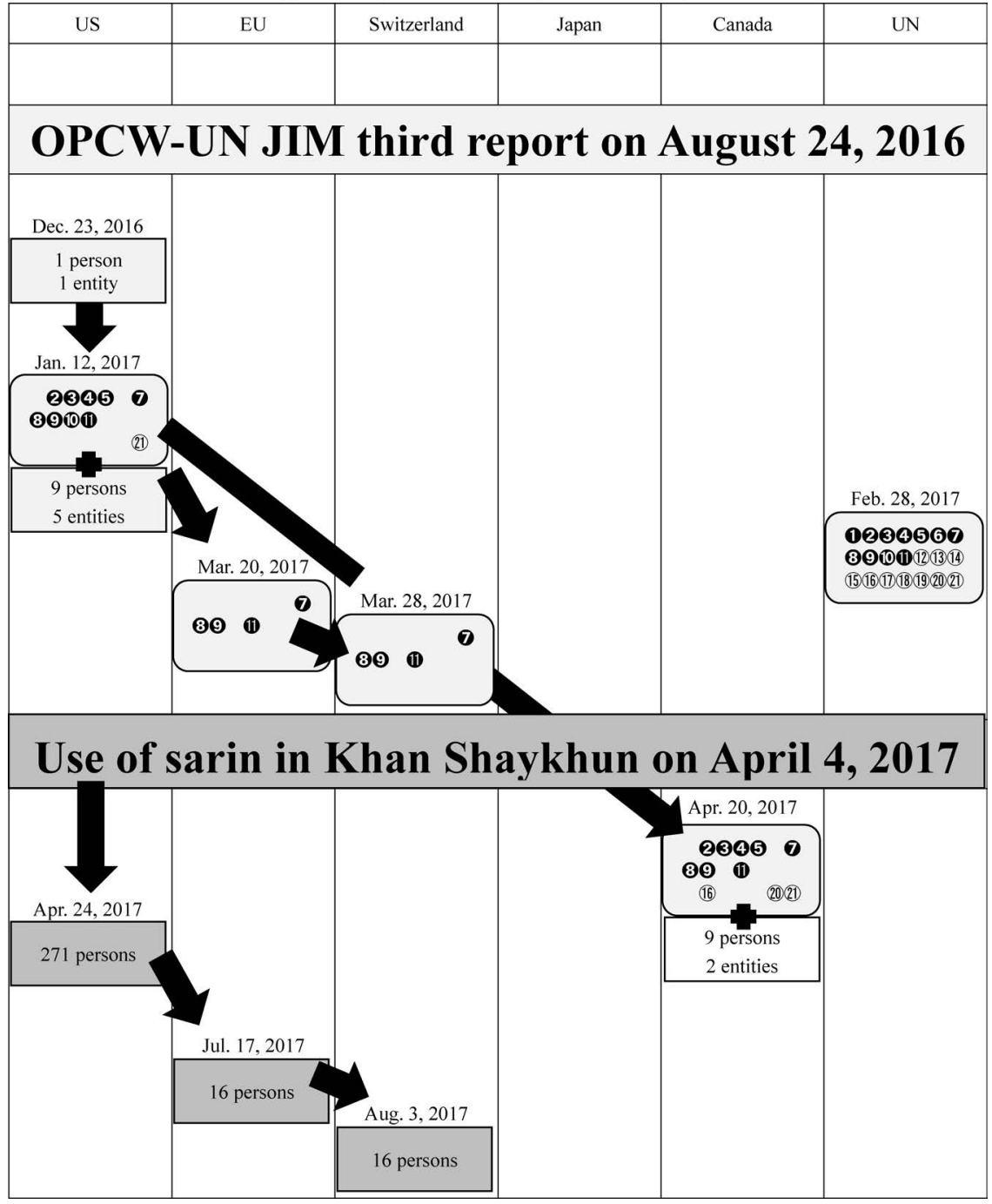

Badi'Mualla, and \#11 Major General Ahmad Ballul. ${ }^{67}$ The EU and Switzerland designated these four individuals in March 2017. ${ }^{68}$ Canada followed the US actions in April 2017. ${ }^{69}$

As a result, almost all key targets have been designated by major industrialized States or regional organizations. This is mainly because they share a common interest in the prevention of chemical proliferation and the nonuse of chemical weapons. It should be noted that Switzerland always follows the EU sanction measures in practice. Its list of designations is identical to that of the EU. As pointed out by Gestri, Switzerland has replicated almost all EU sanctions, but, in 


\section{Tatsuya Abe}

any case, the decision to align with an EU measure must be made by the federal Council on a case-by-case basis after a careful consideration of all the interests involved. ${ }^{70}$

\section{(B) PERIOD OF REFRAINING FROM TAKING ADDITIONAL AUTONOMOUS}

\section{SANCTION MEASURES}

There was a period during which no additional autonomous sanction measures were taken. It occurred between late August 2013 and late July 2014. Irrespective of the fact that the UN mission confirmed the use of sarin on August 21, 2013, no additional autonomous sanction measures were taken until late July 2014. This is quite understandable. During this period, the unprecedented concerted efforts to eliminate Syrian chemical weapons were ongoing. The tragic incident in Ghouta shocked the international community. However, it also broke a political stalemate and united the international community in the goal of eliminating Syrian chemical weapons. A general framework was established by the bilateral agreement between the United States and Russia. ${ }^{71}$ The unprecedented elimination activities followed, starting in September 2013, with the adoption and implementation of the OPCW Executive Council Decision entitled "Decision on Destruction of Syrian Chemical Weapons" 72 and UN Security Council Resolution 2118. ${ }^{73}$ The international community united to implement them with a view to meeting the original deadline - the end of June 2014 - for the elimination of Syrian chemical weapons. Thanks to worldwide cooperation and assistance, the chemical weapons were successfully removed from Syria on June 23, 2014. ${ }^{74}$ It seems that no State wanted to spoil the international efforts during this period.

\section{(2) Diversity}

\section{(A) DIFFERENCES IN INTERESTS}

It should not be forgotten that one can also recognize differences in the previously mentioned autonomous sanction measures. The level of interest is different among States and regional organizations. At one end of the spectrum, Japan has been less active in terms of autonomous sanction measures against Syria. The number of targets Japan has designated is fewer than that of other States and regional organizations. Japan has not taken action since November 2011 or imposed sanction measures in response to the use of chemical weapons. This is probably due to geographical and economic factors. Japan is far away from the Middle East, and it maintains few, if any, economic relations with Syria due to ongoing domestic conflict. At the other end of the spectrum, the Trump Administration in the US took the significant step of designating 271 employees of the SSRC. No other States or regional organizations have followed the US yet in this regard. In conjunction with its military action against the Assad regime, this should be understood, irrespective of subsequent actions followed by other States or regional organizations, as one of the strongest messages of the US to Syria: "We hold the entire Assad 
regime accountable for these blatant human rights violations in order to deter the spread of these types of barbaric chemical weapons." 75

\section{(B) DIFFERENCES IN TIMING}

The timing of designations is also different not only among States and regional organizations but also between the administrations of the same State. In early March 2015, the EU took autonomous sanction measures in response to the use of sarin on August 21, 2013. They were taken based on their own understanding that sarin was used by the Syrian government. On the one hand, the UK, France, and the US took the position that the attack was carried out by the Assad regime. ${ }^{76}$ On the other hand, Syria categorically denied this allegation. ${ }^{77}$ Russia shared the same view as Syria. ${ }^{78}$ The UN mission did not clarify anything regarding the attribution of responsibility due to a lack of mandate. The incident in Ghouta was outside of the scope of the OPCW-UN JIM. Thus, there has been no objective assessment in this regard. It is curious that Switzerland followed the EU, ${ }^{79}$ but that the US and Canada did nothing in the context of the use of sarin. ${ }^{80}$ On January 12, 2017, one of the last days of outgoing president Barack Obama's Administration, the US finally acted, for the first time, in the context of the use of chemical weapons. It seems that the Obama Administration was very careful about the decision to take autonomous sanction measures in response to the use of chemical weapons. Even when the use of chlorine was confirmed by the OPCW FFM in 2014 and 2015, the US did not take any action. Perhaps the US was waiting for an objective confirmation from the OPCW-UN JIM that chlorine was used by the Assad regime. The US sanctions were followed by a proposal for UN sanction measures. Having realized that a draft resolution had been vetoed by Russia and China, the EU and Switzerland decided to add to their sanction lists the individuals and entities that were on the list of UN sanction measures but not yet designated by themselves. ${ }^{81}$

Contrary to the previous administration, the Trump Administration quickly responded to this serious incident. The US took military actions against the Assad regime two days later and decided to strengthen economic sanction measures pursuant to E.O. 13582 by adding 271 SSRC employees to the list on April 24. ${ }^{82}$ The EU also designated eight high-ranking military officials and eight scientists involved in chemical weapons proliferation and delivery to be included in the sanctions list. ${ }^{83}$ Switzerland took the same action within two weeks. ${ }^{84}$ These actions were controversial because they were carried out well in advance of the OPCW-UN JIM's conclusion regarding who had used sarin. The report was made public on October 26, 2017.

\section{Conclusion}

The issues related to Syrian chemical weapons are complicated, as are autonomous sanction measures. Without a legally binding UN resolution, there are no universal sanction measures. Therefore, each State or regional organization must 


\section{Tatsuya Abe}

decide whether autonomous sanction measures are necessary. If the answer is affirmative, the next questions are what measures will be appropriate and when they should be decided upon. This is the case with Syria. As was illustrated previously, major industrialized States or regional organizations - the US, the EU, Switzerland, Japan, and Canada - have taken autonomous sanction measures against Syria. This article made a comparative analysis of these autonomous sanction measures by focusing on their purposes and designations.

It is true that each State or regional organization has its own approach to autonomous sanction measures. Their purpose is not always singular or the same. ${ }^{85}$ Their timing is usually different. Decisions on autonomous sanction measures have been affected by developments in the Syrian chemical weapons situation, such as the unexpected start of elimination, the continued use of toxic chemicals, the establishment and operation of ad hoc investigation procedures, the cooperation and confrontation among States concerned, and so on. One should not forget that chemical weapons issues are only one aspect of the domestic conflict in Syria. Autonomous sanction measures have therefore required adaptation.

At the same time, it is also true that, overall, major industrialized States and regional organizations have designated the same key targets. There must be a common understanding among them that \#12 the Syrian Scientific Studies and Research Centre (SSRC) is the most critical institution. ${ }^{86}$ This is encouraging because collective actions are more effective than individual ones. In this regard, the "Chemical Weapons No Impunity!" campaign ${ }^{87}$ may become a useful platform and contribute to more effective implementation of autonomous sanction measures. On January 23, 2018, France and around 30 other States launched the International Partnership against Impunity for the Use of Chemical Weapons with a view to supplementing the international mechanisms to combat the proliferation of chemical weapons. The participating States have committed "to use all existing mechanisms to identify the individuals and entities by providing all available documentation and supporting multilateral action to sanction them" and "to publish the names of all individuals, entities, groups, or governments which have been subject to sanctions" and will meet regularly to exchange information for implementing their commitments. Further developments in this campaign can be expected to attract intense attention.

\section{Notes}

* This work was supported by JSPS KAKENHI Grant Number 16H01982.

1 Natalino Ronzitti, "Sanctions as Instruments of Coercive Diplomacy: An International Law Perspective," in Natalino Ronzitti ed., Coercive Diplomacy, Sanctions and International Law (Brill, Nijhoff, 2016), p. 11.

2 "Syria Sanctions Program," Office of Foreign Assets Control, Department of the Treasury (August 2, 2013), available at <www.treasury.gov/resource-center/sanctions/ Programs/Documents/syria.pdf $>$.

350 U.S.C. $\S \S 1701$ et seq.

450 U.S.C. $\S \S 1601$ et seq.

5 Pub. L. 108-175. 
622 U.S.C. $§ 287 \mathrm{c}$.

7 "Syria Sanctions Program," supra note 2, p. 4.

8 Data is available through the "Sanctions List Search," available at $<$ https://sanctionssearch.ofac.treas.gov/>.

9 Francesco Giumelli, "From Effective to Useful Sanctions: Lessons Learned from the Experience of the European Union," in Natalino Ronzitti ed., Coercive Diplomacy, Sanctions and International Law (Brill, Nijhoff, 2016), pp. 253-254.

10 Council Decision 2013/186/CFSP lifted the arms embargo due to the desire to support some of the rebel forces in their struggle against the Assad regime (Giumelli, supra note 9, p. 267; and Alexander Orakhelashvili, "Sanctions and Fundamental Rights of States: The case of EU Sanctions Against Iran and Syria," in Matthew Happold and Paul Eden eds., Economic Sanctions and International Law (Hart Publishing, 2016), p. 24.

11 "The EU and the Crisis in Syria," EU (September 24, 2018), available at $<\mathrm{https}$ :/ eeas.europa.eu/headquarters/headquarters-homepage/22664/eu-and-crisis-syriafactsheet en>.

12 "Use of Chemical Weapons in Syria: EU Adds 4 Persons to Sanctions List," European Council (March 19, 2018), available at <www.consilium.europa.eu/en/press/ press-releases/2018/03/19/use-of-chemical-weapons-in-syria-eu-adds-4-persons-tosanctions-list/?utm_source $=$ dsms-auto\&utm_medium $=$ email\&utm_campaign $=$ Use + of + chemical +weapons + in + Syria $\% 3 a+E U+$ adds $+4+$ persons + to + sanctions + list $>$.

13 Ordonnance du 18 mai 2011 instituant des mesures à l'encontre de la Syrie/ Verordnung über Massnahmen gegenüber Syrien vom 18. Mai 2011.

14 Ordonnance du 8 juin 2012 instituant des mesures à l'encontre de la Syrie/ Verordnung über Massnahmen gegenüber Syrien vom 8. Juni 2012.

15 Data is available through the "Recherche des destinataires de sanctions," available at <www.seco.admin.ch/seco/fr/home/Aussenwirtschaftspolitik_Wirtschaftliche Zusammenarbeit/Wirtschaftsbeziehungen/exportkontrollen-und-sanktionen/ sanktionen-embargos/sanktionsmassnahmen/suche_sanktionsadressaten.html>.

16 Special Economic Measures Act, S.C. 1992, c. 17, available at $<$ http://laws-lois. justice.gc.ca/eng/acts/S-14.5/FullText.html>.

17 Special Economic Measures (Syria) Regulations, P.C. 2011-594, available at $<w w w$. gazette.gc.ca/rp-pr/p2/2011/2011-06-08/html/sor-dors114-eng.html>.

18 U.N. Doc. S/2017/172 (February 28, 2017). The number of sponsors reached 42.

19 Ibid., operative para.1.

20 U.N. Doc. S/PV.7893 (February 28, 2017), p. 4. There were nine votes in favor, three against (Bolivia, China, and Russia) and three abstentions (Egypt, Ethiopia, and Kazakhstan).

21 The 42 sponsoring States were Albania, Australia, Austria, Belgium, Bulgaria, Canada, Croatia, Cyprus, the Czech Republic, Denmark, Estonia, Finland, France, Germany, Greece, Iceland, Ireland, Israel, Italy, Japan, Latvia, Liechtenstein, Lithuania, Luxembourg, Malta, Montenegro, the Netherlands, New Zealand, Norway, Poland, Portugal, Qatar, Romania, Saudi Arabia, Slovakia, Spain, Sweden, Turkey, Ukraine, the United Arab Emirates, the United Kingdom of Great Britain and Northern Ireland, and the United States of America. In addition, two non-sponsoring nonpermanent members of the Security Council (Senegal and Uruguay) voted in favor.

22 Testimony of William H. Webster, Director, Central Intelligence Agency, Washington, $D C$, Global Spread of Chemical and Biological Weapons, Hearings Before the Committee on Governmental Affairs and Its Permanent Subcommittee on Investigations, United States Senate, one hundred-first Congress, first session (February 9, 1989), p. 12.

23 "News Chronology: August through November 1992," Chemical Weapons Convention Bulletin, No. 18 (December 1992), pp. 8, 15. 


\section{Tatsuya Abe}

24 "Convention on the Prohibition of the Development, Production, Stockpiling, and Use of Chemical Weapons and on Their Destruction," United Nations Treaty Series, Vol. 1974, No. 33757, p. 45.

25 W. Seth Carus, "Chemical Weapons in the Middle East," Policy Focus, The Washington Institute for Near East Policy, No. 9 (December 1988), p. 5 ("The Syrian chemical warfare program operates under the auspices of CERS, a research organization located near Damascus. Additional facilities of an unknown type may be located in Homs, a city north of Damascus"); and Shlomo Gazit ed., The Middle East Military Balance, 1993-1994 (Boulder, CO: Westview Press for the Jaffee Center for Strategic Studies, 1994), p. 229 ("Any discussion of Syrian nonconventional capability would not be complete without mention of the organization behind them: CERS (Centre d'Etudes et de Recherche Scientifique), based in Damascus. This poses as a civilian research center, with official ties to research centers around the world, but is also responsible for most of the chemical and biological weapons research (and possibly production).") See also "Syria's Chemical Weapons Stockpile," BBC News (January 30, 2014), available at <www.bbc.com/news/world-middle-east-22307705>. ("Before the uprising, the Syrian Scientific Studies and Research Centre (CERS) was believed to run at least four chemical agent manufacturing plants - at Dumayr, Khan Abou, Shamat, and Furklus and operate additional storage sites dispersed across the country in some 50 different towns and cities.")

26 US Department of State, "Executive Order 13382," available at <www.state.gov/t/isn/ c22080.htm>.

27 US Department of the Treasury, "Three Entities Targeted by Treasury for Supporting Syria's WMD Proliferation," (January 4, 2007), available at <www.treasury.gov/ press-center/press-releases/Pages/hp216.aspx>.

28 US Department of the Treasury, "Treasury Increases Sanctions Against Syria" (July 18, 2012), available at <www.treasury.gov/press-center/press-releases/Pages/ $\operatorname{tg} 1642 . \operatorname{aspx}>$. The US also designated a total of three Syrian banks in August 2011 and May 2012 ("Treasury Sanctions State-Owned Syrian Financial Institutions and Syria's Largest Mobile Phone Operator," US Department of the Treasury (August 10, 2011), available at <www.treasury.gov/press-center/press-releases/Pages/tg1273. aspx>; "Treasury Sanctions Syria International Islamic Bank," US Department of the Treasury (May 30, 2012), available at <www.treasury.gov/press-center/press-releases/ Pages/tg1596.aspx $>$ ).

29 "Treasury Designates Syrian Entity, Others Involved in Arms and Communications Procurement Networks and Identifies Blocked Iranian Aircraft," US Department of the Treasury (September 19, 2012), available at <www.treasury.gov/press-center/pressreleases $/$ Pages $/ \operatorname{tg} 1714$.aspx $>$.

30 "Syria Says Could Use Chemical Arms Against Foreigners," Reuters (July 23, 2012), available at <www.reuters.com/article/us-syria-crisis/syria-says-could-use-chemicalarms-against-foreigners-idUSBRE8610SH20120723>; and "Syria Threatens Chemical Attack on Foreign Force," New York Times (July 23, 2012), available at <www. nytimes.com/2012/07/24/world/middleeast/chemical-weapons-wont-be-used-inrebellion-syria-says.html>.

31 cf. Daniel H. Joyner, "UN Counter-Proliferation Sanctions and International Law," in Larissa van den Herik ed., Research Handbook on UN Sanctions and International Law (Edward Elgar Publishing, 2017), p. 111.

32 cf. Orakhelashvili, supra note 10, p. 35.

33 Council Decision 2011/782/CFSP (December 1, 2011).

34 Canada, Regulations Amending the Special Economic Measures (Syria) Regulations, P.C. 2011-1727 (December 22, 2011); and Switzerland, Ordonnance du 18 mai 2011 instituant des mesures à l'encontre de la Syrie (Etat le 7 février 2012)/ Verordnung über Massnahmen gegenüber Syrien vom 18. Mai 2011 (Stand am 7. Februar 2012). 
35 "Regulatory Impact Analysis Statement," Regulations Amending the Special Economic Measures (Syria) Regulations, P.C. 2011-1727 (December 22, 2011).

36 Ordonnance du 18 mai 2011 instituant des mesures à l'encontre de la Syrie (Etat le 7 février 2012), Annexe 2/ Verordnung über Massnahmen gegenüber Syrien vom 18. Mai 2011 (Stand am 7. Februar 2012), Anhang 2.

37 Ministry of Foreign Affairs, "Addition of Lists for the Measures to Freeze the Assets of President Bashar Al-Assad and His Related Individuals and Entities in Syria," The Attached Notes (December 22, 2011), available at <www.mofa.go.jp/announce/ announce/2011/12/pdfs/1222_04_01.pdf >; and Ibid., (November 27, 2012), available $a t<$ www.mofa.go.jp/announce/announce/2012/11/1127_01.html $>$.

38 See also the designation of one entity (\#13) (EU, Council Decision 2012/634/CFSP (October 15, 2012); Switzerland, Ordonnance du 8 juin 2012 instituant des mesures à l'encontre de la Syrie (Etat le 27 octobre 2012), Annexe 7/ Verordnung über Massnahmen gegenüber Syrien vom 8. Juni 2012 (Stand am 27. Oktober 2012), Anhang 7; Canada, Regulatory Impact Analysis Statement, Regulations Amending the Special Economic Measures (Syria) Regulations, P.C. 2012-1577 (November 26, 2012) and one individual and two entities (\#1, \#16 and \#20) (EU, Council Implementing Decision 2014/488/CFSP (July 22, 2014); Switzerland, Ordonnance du 8 juin 2012 instituant des mesures à l'encontre de la Syrie (Etat le 10 septembre 2014) / Verordnung über Massnahmen gegenüber Syrien vom 8. Juni 2012 (Stand am 10. September 2014).

39 U.N. Doc. A/67/997-S/2013/553 (September 16, 2013), p. 8, paras. 27-28.

40 U.N. Doc. S/RES/2118 (2013) (September 27, 2013), para. 2.

41 Council Implementing Decision (CFSP) 2015/383 (March 6, 2015).

42 Ordonnance du 8 juin 2012 instituant des mesures à l'encontre de la Syrie (Etat le 16 mars 2015)/ Verordnung über Massnahmen gegenüber Syrien vom 8. Juni 2012 (Stand am 18. März 2015).

43 OPCW Doc. S/1191/2014 (June 16, 2014), p. 1, para. 1. This initiative was endorsed by the OPCW Executive Council (OPCW Doc. EC-M-48/DEC.1 (February 4, 2015), preamble para. 8) and the Security Council (U.N. Doc. S/RES/2209 (2015) (March 6, 2015), para. 5), respectively. It should be noted that the task of the FFM does not include addressing the question of attributing responsibility for the alleged use.

44 OPCW Doc. S/1191/2014 (June 16, 2014), Annex 2, para. 53; and OPCW Doc. S/1212/2014 (September 10, 2014), Annex 2, para. 29. See also OPCW Doc. S/1230/2014 (December 18, 2014).

45 U.N. Doc. S/RES/2209 (2015) (March 6, 2015), para 2.

46 OPCW Doc. S/1319/2015 (October 29, 2015), Annex 2, para. 5.8; OPCW Doc. S/1320/2015 (October 29, 2015), Annex, para. 4.6; and OPCW Doc. S/1491/2017 (May 1, 2017), para. 6.3.

47 U.N. Doc. S/RES/2235 (2015) (August 7, 2015).

48 U.N. Doc. S/2016/738/Rev.1 (August 24, 2016), Annex IV, para. 56, Annex VII, para. 53, Annex VIII, para. 70, Annex X, para. 41; U.N. Doc. S/2016/888 (October 21, 2016), para. 19; and U.N. Doc. S/2017/904 (October 26, 2017), p. 9, para. 36.

49 US Department of the Treasury, "Treasury Sanctions Syrian Officials In Connection With OPCW-UN Findings of Regime's Use of Chemical Weapons on Civilians," (January 12, 2017), available at <www.treasury.gov/press-center/press-releases/Pages/ j10701.aspx>.

50 Reuters, "Scores Reported Killed in Gas Attack on Syrian Rebel Area," (April 4, 2017), available at <www.reuters.com/article/us-mideast-crisis-syria-idlib/ scores-reported-killed-in-gas-attack-on-syrian-rebel-area-idUSKBN1760IB >; and The Guardian, "Syria Chemical Weapons Attack Toll Rises to 70 as Russian Narrative Is Dismissed," (April 5, 2017), available at <www.theguardian.com/world/2017/ apr/04/syria-chemical-attack-idlib-province $>$. The US, the UK, and France argued that 
sarin was used by the Assad regime (Statement by Ambassador Kenneth D. Ward, United States Delegation to the Executive Council, Organization for the Prohibition of Chemical Weapons, The Fifty-Fourth Meeting of the Executive Council EC-M-54 (April 13, 2017), available at <www.opcw.org/fileadmin/OPCW/EC/M-54/en/United States_ECM54_Statement.pdf $>$; White House, The Assad Regime's Use of Chemical Weapons on April 4, 2017; United Kingdom of Great Britain and Northern Ireland, Statement by H.E. Ambassador Sir Geoffrey Adams, Permanent Representative of the United Kingdom of Great Britain and Northern Ireland to the OPCW at the FiftyFourth Meeting of the Executive Council, OPCW Doc. EC-M-54/NAT.19 (April 13, 2017); National Evaluation, Chemical Attack of April 4, 2017 (Khan Sheikhoun), Clandestine Syrian Chemical Weapons Program, available at $<$ www.diplomatie. gouv.fr/IMG/pdf/170425___evaluation_nationale_-_anglais_-_final_cle0dbf47-1. pdf $>$.

51 OPCW Press Release on Allegations of Chemical Weapons Use in Southern Idlib, Syria (April 4, 2017), available at <www.opcw.org/news/article/opcw-press-releaseon-allegations-of-chemical-weapons-use-in-southern-idlib-syria/>.

52 OPCW Doc. S/1510/2017 (June 29, 2017), paras. 6.4 and 6.25; and U.N. Doc. S/2017/904 (October 26, 2017), p. 10, para. 46.

53 US Department of Defense, "Trump Orders Missile Attack in Retaliation for Syrian Chemical Strikes" (April 6, 2017), available at <www.defense.gov/News/Article/Article/ 1144601/trump-orders-missile-attack-in-retaliation-for-syrian-chemical-strikes/>; and US Department of the Treasury, "Treasury Sanctions 271 Syrian Scientific Studies and Research Center Staff in Response to Sarin Attack on Khan Sheikhoun" (April 24, 2017), available at <www.treasury.gov/press-center/press-releases/Pages/sm0056. aspx>.

54 Council Implementing Decision (CFSP) 2017/1341 (July 17, 2017).

55 Ordonnance du 8 juin 2012 instituant des mesures à l'encontre de la Syrie (Etat le 3 août 2017)/ Verordnung über Massnahmen gegenüber Syrien vom 8. Juni 2012 (Stand am 3. August 2017).

56 US Department of State, supra note 26.

57 US Department of the Treasury, supra note 27.

58 EU, Council Decision 2011/782/CFSP (December 1, 2011); Japan, Ministry of Foreign Affairs, supra note 37; Canada, Regulations Amending the Special Economic Measures (Syria) Regulations, P.C. 2011-1727 (December 22, 2011); and Switzerland, Ordonnance du 18 mai 2011 instituant des mesures à l'encontre de la Syrie (Etat le 7 février 2012)/ Verordnung über Massnahmen gegenüber Syrien vom 18. Mai 2011 (Stand am 7. Februar 2012).

59 EU, Council Implementing Decision 2014/488/CFSP (July 22, 2014); and Switzerland, Ordonnance du 8 juin 2012 instituant des mesures à l'encontre de la Syrie (Etat le 10 septembre 2014) / Verordnung über Massnahmen gegenüber Syrien vom 8. Juni 2012 (Stand am 10. September 2014).

60 Canada, Regulations Amending the Special Economic Measures (Syria) Regulations, P.C. 2017-407 (April 20, 2017).

61 Council Decision 2011/782/CFSP (December 1, 2011).

62 Canada, Regulations Amending the Special Economic Measures (Syria) Regulations, P.C. 2011-1727 (December 22, 2011); and Switzerland, Ordonnance du 18 mai 2011 instituant des mesures à l'encontre de la Syrie (Etat le 7 février 2012)/ Verordnung über Massnahmen gegenüber Syrien vom 18. Mai 2011 (Stand am 7. Februar 2012).

63 US Department of the Treasury, supra note 28.

64 Ministry of Foreign Affairs, supra note 37, (November 27, 2012).

65 Council Implementing Decision (CFSP) 2015/383 (March 6, 2015).

66 Ordonnance du 8 juin 2012 instituant des mesures à l'encontre de la Syrie (Etat le 16 mars 2015)/ Verordnung über Massnahmen gegenüber Syrien vom 8. Juni 2012 (Stand am 18. März 2015). 
67 US Department of the Treasury, supra note 49.

68 EU, Council Implementing Decision (CFSP) 2017/485 (March 20, 2017); and Switzerland, Ordonnance du 8 juin 2012 instituant des mesures à l'encontre de la Syrie (Etat le 28 mars 2017) / Verordnung über Massnahmen gegenüber Syrien vom 8. Juni 2012 (Stand am 28. März 2017).

69 Canada, Regulations Amending the Special Economic Measures (Syria) Regulations, P.C. 2017-407 (April 20, 2017).

70 Gestri, supra note 38, pp. 76-77. Article 1 of the Federal Act on the Implementation of International Sanctions of March 22, 2002, stipulates that "The Confederation may enact compulsory measures in order to implement sanctions that have been ordered by the United Nations Organisation, by the Organisation for Security and Cooperation in Europe, or by Switzerland's most significant trading partners and which serve to secure compliance with international law, and in particular the respect of human rights." Needless to say, the EU is one of "Switzerland's most significant trading partners."

71 OPCW Doc. EC-M-33/NAT.1 (September 17, 2013); and U.N. Doc. A/68/398 S/2013/565 (September 24, 2013).

72 OPCW Doc. EC-M-33/DEC.1 (September 27, 2013).

73 U.N. Doc. S/RES/2118(2013) (September 27, 2013).

74 OPCW Doc. EC-76/6 (July 11, 2014), para. 6.14.

75 US Department of the Treasury, supra note 53.

76 UK, Letter from the Chairman of the Joint Intelligence Committee (JIC) about reported chemicalweaponsuseinSyria(August29,2013), availableat<www.gov.uk/government/ uploads/system/uploads/attachment_data/file/235094/Jp_115_JD_PM_Syria_ Reported_Chemical_Weapon_Use_with_annex.pdf>; US, Government Asssessment of

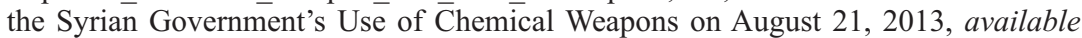
at $<$ https://obamawhitehouse.archives.gov/the-press-office/2013/08/30/governmentassessment-syrian-government-s-use-chemical-weapons-august-21>; Syria: Damascus Areas of Influence and Areas Reportedly Affected by 21 August Chemical Attack, available at $<\mathrm{https}$ ://obamawhitehouse.archives.gov/sites/default/files/docs/2013-08$30 \_$map_accompanying_usg_assessment_on_syria.pdf $>$; and France, Syrian Chemical Programme - National Executive Summary of Declassified Intelligence (September 2, 2013), available at <www.diplomatie.gouv.fr/en/IMG/pdf/Syrian_Chemical_ Programme.pdf $>$.

77 Timeline of Syrian Chemical Weapons Activity, 2012-2018 (August 26, 2013), Arms Control Association, available at <www.armscontrol.org/factsheets/Timelineof-Syrian-Chemical-Weapons-Activity $>$.

78 OPCW Doc. EC-M-33/NAT.20 (October 3, 2014).

79 Ordonnance du 8 juin 2012 instituant des mesures à l'encontre de la Syrie (Etat le 10 septembre 2014) (Etat le 17 decembre 2014) (Etat le 16 mars 2015)/ Verordnung über Massnahmen gegenüber Syrien vom 8. Juni 2012 (Stand am 10. September 2014) (Stand am 16. Dezember 2014) (Stand am 18. März 2015).

80 It is true that the US designated a total of eight entities close to the SSRC; however, the legal basis for the designations was E.O. 13382 ("Treasury Sanctions Companies for Aiding the Syrian Regime," US Department of the Treasury (July 9, 2014)), available at <www.treasury.gov/press-center/press-releases/Pages/j12558.aspx>; "Treasury Targets Syrian Regime Financial and Weapons," US Department of the Treasury (March 31, 2015), available at <www.treasury.gov/press-center/press-releases/Pages/ JL10013.aspx>; and "Treasury Sanctions Networks Providing Support to the Government of Syria," US Department of the Treasury (July 21, 2016), available at <www. treasury.gov/press-center/press-releases/Pages/j10526.aspx>.

81 EU, Council Implementing Decision (CFSP) 2017/485 (March 20, 2017); and Switzerland, Ordonnance du 8 juin 2012 instituant des mesures à l'encontre de la Syrie (Etat le 28 mars 2017)/ Verordnung über Massnahmen gegenüber Syrien vom 8. Juni 2012 (Stand am 28. März 2017). Canada essentially followed the US sanction measures 


\section{Tatsuya Abe}

though it took actions after the Khan Shaykhun incident (Regulations Amending the Special Economic Measures (Syria) Regulations, P.C. 2017-407 (April 20, 2017)).

82 US Department of Defense, supra note 53; US Department of the Treasury, supra note 53.

83 Council Implementing Decision (CFSP) 2017/1341 (July 17, 2017).

84 Ordonnance du 8 juin 2012 instituant des mesures à l'encontre de la Syrie (Etat le 3 août 2017)/ Verordnung über Massnahmen gegenüber Syrien vom 8. Juni 2012 (Stand am 3. August 2017).

85 Giumelli points out that sanctions are partly ex-post, but also partly ex-ante, since they also target future behaviors of the regime (Giumelli, supra note 9, p. 265).

86 Due to "gaps, inconsistencies, and discrepancies" in the declaration of Syria, the OPCW Executive Council tasked the Technical Secretariat with carrying out inspections at the Barzah and Jamrayah facilities of the SSRC (OPCW Doc. EC-83/DEC.5 (November 11, 2016), para. 11).

87 See the official website at <www.noimpunitychemicalweapons.org/-en-.html > . 


\title{
12 Russia
}

\section{The Crimea question and autonomous sanctions}

\author{
Mika Hayashi*
}

\section{Introduction}

In May 2018, four years after the annexation of Crimea, Russia succeeded in building a bridge that connected the Crimean Peninsula to the Russian mainland. Until then, the only land route to Crimea was via Ukraine. The bridge, for the States that currently impose sanctions on Russia, "represents yet another violation of Ukraine's sovereignty," and is "an attempt by Russia to solidify its unlawful seizure and its occupation of Crimea." Russia, however, is unfazed, as can be seen in its embassy's response, posted on Facebook: "Crimea is Russia. We shall not ask for anybody's permission to build transport infrastructure for the sake of the population of Russian regions." ${ }^{3}$ Under the circumstances, the most sensible course of action for the States that condemn the annexation is to "continue to work with partners to oppose the annexation, including by maintaining a robust package of sanctions." 4 This chapter will discuss the package of these sanctions.

The sanctions on Russia that are currently in place have a few distinct features when compared to the sanction regimes on North Korea, Iran, and Syria, which were discussed in the previous chapters. In contrast to the sanctions on North Korea and Iran that are, in large part, crafted as United Nations (UN) sanctions, the package of sanctions against Russia consists of autonomous sanctions by multiple States and the European Union (EU), which are unilaterally carried out outside the UN framework. This means that the necessity, the legitimacy, and the design of the sanctions are determined without a common frame of reference or point of coordination formally. There is no Security Council resolution to which to turn in evaluating the design, legality, or effectiveness of the sanctions. There is no Sanctions Committee or Panel of Experts to help monitor the implementation of the sanctions.

In this light, there are a few common features shared by the sanctions on Russia and the sanctions on Syria. Both are autonomous sanctions. The EU and the United States are the strongest proponents of these autonomous sanctions, and to a certain extent, what they decide to do and how they design their sanctions has become a frame of reference for others. As a result, there is a certain degree of alignment among various sanctions by multiple States and the EU, although each sanction has been autonomously designed and implemented. 
At the same time, despite the apparent similarities between the sanctions on Russia and the sanctions on Syria, there are also important differences. The first source of differences in the two cases is purely factual and is almost too obvious to describe: Russia is a far more important economic player and trade partner than Syria for the majority of States in the world. Hence, the sanctions on Russia present a far more divisive issue for the international community than the sanctions on Syria. Accordingly, there are States that tag along in the sanction efforts against Russia but are clearly unenthusiastic. There are also more internal tensions within the EU regarding the sanctions on Russia than the sanctions on Syria. The second difference between the two cases that must be kept in mind is that the sanctions on Russia could be considered a tool of nonrecognition regarding the unlawful situation. They are not simply a tool of coercive diplomacy.

These distinctive features, as well as several other aspects, of the sanctions on Russia will be discussed in this chapter. After a brief overview of the reasons for these sanctions (I), the chapter will first examine the sanctions by the EU (II.1), as the EU is the biggest trade partner for Russia and the most active proponent of the sanctions besides the United States. The chapter will then examine the sanctions by a few other States that are equally strong supporters of the sanctions (II.2), as well as the contrasting examples of less enthusiastic States (II.3). The questions to be examined are divided into two groups: those regarding the legality of the sanctions and their effectiveness. The analysis of the sanctions' legality will again focus on the sanctions by the EU, and it will include an examination of the reactions by Russia, which considers these sanctions illegitimate and illegal (III.1). The effectiveness of the sanctions on Russia is examined from two perspectives: the sanctions as a tool of nonrecognition policy and the question of implementation in light of breaches and evasions (III.2).

\section{Reasons for the sanctions on Russia}

\section{Initial phase: Referendum in Crimea and its annexation (March 2014)}

A referendum was organized in Crimea in March 2014, and the outcome upheld its secession from Ukraine. The referendum, according to the States in support of Ukraine, was "not authorized by Ukraine" and had "no validity." According to Russia, it "was held . . . in full compliance with democratic procedures and international norms." Given this sharp disagreement, the Security Council was unable to adopt a resolution on the issue. ${ }^{7}$ Russia, welcoming the outcome of the referendum, also took steps to incorporate the region into Russia. ${ }^{8}$ This was condemned as an annexation by Ukraine. ${ }^{9}$

\section{Escalation: Destabilization in Eastern Ukraine (summer 2014)}

In the wake of the annexation of Crimea, there were also uprisings by pro-Russian separatists in the Eastern Ukrainian region. ${ }^{10}$ Two areas in the region, Luhansk 
and Donetsk, eventually declared themselves independent "people's republics." 11 The fighting between the pro-Russian activists in the region and the Ukrainian forces peaked in the summer of 2014. The level of violence was such that the International Committee of the Red Cross (ICRC) characterized the situation as an armed conflict. ${ }^{12}$ The Russian support for the pro-Russian separatists, including its physical presence, was strongly condemned in the Security Council debate, ${ }^{13}$ while Russia denied its involvement in the destabilization in Eastern Ukraine. ${ }^{14}$

On July 17, 2014, a Malaysian Airlines flight flying over the region was shot down. ${ }^{15}$ An independent investigation later confirmed that the missile used in this incident was Russian. ${ }^{16}$ Consequently, the Netherlands and Australia, the two States that were most affected in terms of the number of victims, informed Russia that they considered Russia responsible for the downing of the flight. ${ }^{17}$ Russia did not accept the findings of this investigation. ${ }^{18}$ In early September 2014, a ceasefire agreement known as "Minsk I" was reached. ${ }^{19}$ However, the calm was only temporary. In November, local elections were held in the region in violation of "Minsk I." 20

\section{Failure of "Minsk II" and stalemate in Eastern Ukraine (2015 to the present)}

The ceasefire based on "Minsk I" did not last. ${ }^{21}$ Another package of agreements was reached in February 2015, known as "Minsk II." 22 The parties to the conflict agreed under "Minsk II" to an immediate ceasefire, withdrawal of heavy weaponry, reestablishment of Ukrainian control over the conflict zone, and so on. However, the implementation deadline of December 2015 was missed. "The ceasefire has been violated almost every day for the last two years," remarked the Deputy Secretary General of NATO in $2017 .^{23}$ The OSCE's monitoring mission confirms the same daily violations of the ceasefire. ${ }^{24}$ Occasional spikes in the fighting, a succession of ceasefires, and violations of the agreed ceasefires characterize the situation. Currently, there is no prospect of a political settlement to bring the regions held by the separatists under the control of the Ukrainian authorities. The situation is therefore often called a "frozen war" or a "frozen conflict." 25

\section{Spectrum of sanctions}

The sanctions on Russia adopted by the EU and other States have shown changes over time. They were initially a response to the annexation of Crimea described in Section I.1. The uprisings in the Eastern Ukrainian region and their escalation into an armed conflict with the involvement of Russia described in Section I.2 prompted many of these States to reinforce their sanctions. Most of the sanctions progressively reinforced are still in place today because of the frozen situation described in Section I.3. The sanctions on Russia adopted by the EU and other States vary in their focus and their design, although there is a certain degree of alignment. As the EU is the biggest trade partner of Russia, the restrictive measures imposed by the EU against Russia since March 2014 will be presented first 
(II.1). Several other States are as determined as the EU to oppose Russia and have imposed equally rigorous sanctions on it (II.2). In contrast, there are also States that are more ambivalent or much less enthusiastic about the sanctions, even though they tag along in the sanction efforts (II.3). ${ }^{26}$

\section{Rigorous sanctions: Restrictive measures imposed by the EU}

The first restrictive measure ${ }^{27}$ by the EU beyond the diplomatic measure ${ }^{28}$ in the initial phase consisted of targeted sanctions, establishing a list of targets for asset freezes and travel bans. These targeted sanctions established in March 2014 contained 21 names, including both the Crimean leadership and Russian persons and entities. ${ }^{29}$ The individuals and entities designated in the targeted sanctions were those that have been deemed responsible for actions undermining or threatening the territorial integrity, sovereignty, and independence of Ukraine. Based on this measure, the assets of the targeted individuals or corporations, such as cash, bank deposits, stocks, and shares in the EU, may not be accessed or moved. The real estate in the EU that belongs to the targeted individuals and corporations cannot be sold or rented. The travel ban means that targeted individuals' entry to the EU is prohibited. If a visa is required for entry of a designated individual, the visa is denied.

The list for the targeted sanctions has been regularly reviewed and updated by the Council. As of June 2019, the list has grown to contain 170 individuals and 44 entities. The entities targeted include the two breakaway "people's republics" in Eastern Ukraine as well as former Ukrainian companies that are now under Russian ownership. In August 2017, three individuals and three Russian firms that had been involved in, or assisted, the transfer of Siemens' gas turbines to Crimea were added to the list. ${ }^{30}$ In May 2018, five individuals who had assisted with the Russian presidential election in Crimea were added to the list. In July 2018, six Russian firms that were involved in the construction of the Kerch bridge were added to the list. ${ }^{31}$ The list is reviewed, in principle, every six months. ${ }^{32}$

In the escalation phase, in July and September 2014, the EU also initiated a series of economic (sectoral) sanctions on Russia. It imposed a measure on certain Russian banks and companies to limit their access to EU primary and secondary capital markets, a ban on trade in arms, a ban on export for dual-use goods for military use or military end users, and a measure to limit Russian access to certain sensitive technologies and services that could be used for oil production and exploration. ${ }^{33}$ In the last phase after "Minsk II," when the implementation of the Minsk agreements foreseen for December 2015 did not take place, the EU made a unanimous decision to maintain the economic sanctions for another six months, until July 31, 2016. Since then, the economic sanctions have been reviewed approximately every six months and extended for another six months after each review. ${ }^{34}$

In relation to Crimea and Sevastopol specifically, the EU introduced a general import ban on goods in June $2014 .{ }^{35}$ The measure was quickly reinforced by an amendment in July 2014; a restriction on exports and investments related to 
key economic sectors and infrastructure projects such as the transport, telecommunications, and energy sectors was added. ${ }^{36}$ In December 2014, the restriction of investment in the region was expanded to all sectors, and a new prohibition on supplying the tourism services in the area was introduced. ${ }^{37}$ These restrictive measures regarding Crimea and Sevastopol are reviewed annually. ${ }^{38}$

\section{Other rigorous sanctions}

There are other States besides the EU that are also strongly opposed to the annexation of Crimea and the situation in Eastern Ukraine. These States, such as the United States, Canada, and Australia, impose equally rigorous sanctions against Russia. Many of the measures by these States are comparable to the EU sanctions in their design and in their pattern of progressive reinforcement.

\section{(1) United States}

Like the EU, the first steps taken by the United States in the initial phase included diplomatic measures, such as a suspension of military cooperation with Russia. ${ }^{39}$ Like the EU, the United States then proceeded to implement targeted sanctions as the first sanction against Russia. ${ }^{40}$ In the initial phase, the list announcing the targeted sanctions included seven individuals, mainly Crimean separatists, and one entity. ${ }^{41}$ Within weeks, seven Russians, including "members of the Russian leadership's inner circle, ${ }^{\prime 42}$ were added to the targeted sanctions. In the escalation phase, the targeted sanctions were further expanded to the two breakaway "people's republics" and their leaders and supporters, as well as Russian firms manufacturing weapons and arms. ${ }^{43}$ Their property and property interests in the United States or under the possession or control of US persons are frozen and cannot be transferred, paid, exported, or withdrawn.

The United States also started a series of economic (sectoral) sanctions in the escalation phase. In July 2014, new restrictions in the financial services and energy sectors were announced. A few Russian banks and a few corporations in the energy sector, of both natural gas and oil, were cut off from the US capital market. ${ }^{44}$ Several Russian firms operating in the arms or related materiel sector also came under the sectoral sanctions. Like the EU sectoral sanctions, the US sectoral sanctions resemble the targeted sanctions in that a similar list has been established. The difference between it and the targeted sanctions described earlier is that the list is established for narrower prohibitions that are limited to activities in identified sectors.

In relation to Crimea and Sevastopol specifically, almost all commercial transactions with the region were prohibited by December $2014 .{ }^{45}$ The import of goods, technology, or services from the region is comprehensively prohibited. The US also introduced a general export ban on goods destined for Crimea. Investment in the region is also prohibited. The International Emergency Economic Powers Act, the National Emergencies Act, and the more recent Countering America's Adversaries Through Sanctions Act 2017, form the basis of the sanction-related decisions by the US. 
While both the United States and the EU are proponents of rigorous sanctions against Russia, their sanctions are not identical in design. A few differences are worth highlighting. The US sanctions in the energy sector are designed for both the oil and gas industries, whereas the EU sanctions in the same sector are only designed for the oil industry. The US sanctions are also stricter about activities that were conducted prior to the annexation of Crimea. In general, the US sanctions do not allow such previous activities to continue, whereas the EU restrictive measures take a more relaxed approach to the issue. Finally, while the EU sanctions against Russia have a single purpose, which is to address the conflict over Ukraine, the US sanctions against Russia that are currently in place reflect multiple purposes. ${ }^{46}$

\section{(2) Canada}

Like the EU and the US, Canada has also imposed targeted sanctions on Russia. The Canadian targeted sanctions do not involve travel bans but impose a rigorous asset freeze. The designated persons are those who are, inter alia, "engaged in activities that directly or indirectly facilitate, support, provide funding for or contribute to a violation or attempted violation of the sovereignty or territorial integrity of Ukraine or that obstruct the work of international organizations in Ukraine." ${ }^{\prime 7}$ The Canadian targeted sanctions prohibit persons in Canada, as well as Canadian nationals abroad, from dealing in any property of a designated person under its targeted sanctions. The prohibition includes entering into, or facilitating, any transaction related to such a dealing, and providing any financial service in relation to such a dealing. Making goods available to a designated person, as well as providing any financial or related services to a designated person, is also prohibited.

Regarding Russia, a trade restriction in the oil exploration or production sector is imposed. There is also a financial restriction on several Russian banks and companies. Regarding Crimea and Sevastopol, the scope of the Canadian trade embargo is closer to the US embargo than the EU restriction. There is a complete ban on both import from, and export to, the Crimea region, regardless of the location of the goods. Shipping to and from the Crimea region is explicitly prohibited as well. The Canadian sanctions on Russia are mainly based on its Special Economic Measures Act 1992. The Justice for Victims of Corrupt Foreign Officials Act 2017 has also served as a basis for adding more names to the targeted sanctions. $^{48}$

\section{(3) Australia}

The Australian government announced its intention to impose sanctions on Russia in the initial phase, and by June 2014, its list of targeted sanctions for the travel ban and asset freeze contained several Russian officials. As of March 2018, the Australian list of targeted sanctions includes 153 individuals and 48 entities. ${ }^{49}$ In the escalation phase, Australia expanded its sanctions against Russia. In the words 
of the Prime Minister, Australia was "lift[ing] its sanctions against Russia to the level of the European Union. ${ }^{50}$ It therefore prohibited the arms trade with Russia. Providing technical or financial assistance or service in relation to military activities was also prohibited, as was the provision of services to the oil exploration and production sectors.

In relation to Crimea and Sevastopol specifically, the pattern of trade restriction is closer to the EU restriction than the complete embargo of the United States. The import of all goods from the area is prohibited. The export of both goods and services for the infrastructure sectors in the region, namely, transportation, telecommunications, and energy, is also prohibited. The Australian government also prohibited several activities, such as making financial loans and establishing a joint venture in, or for, the Crimean Peninsula. The measures here are based on the Autonomous Sanctions Regulations 2011, supplemented by the Autonomous Sanctions (Russia, Crimea and Sevastopol) Specification 2015, as well as the Customs (Prohibited Exports) Regulations 1958.

\section{Measures by less enthusiastic States}

In contrast to the EU or the States that implement rigorous sanctions on Russia, there are also a few States that are, or were, not particularly enthusiastic about imposing sanctions against Russia. They have tagged along, but their measures are limited in scope or simply symbolic.

\section{(1) Switzerland}

Switzerland is one of the States that refrained from showing enthusiasm over these sanctions. The Swiss government did condemn the annexation of Crimea by Russia, and a few diplomatic measures were taken in the initial phase. ${ }^{51}$ However, in the same period, Switzerland tried to distance itself from the targeted sanctions announced by the EU and the United States, with its President explicitly stating to media reporters that Switzerland "does not associate itself [with these sanctions] for the moment." 52 Switzerland eventually did establish a targeted sanction: The Swiss financial institutions were therefore prohibited from entering into a business relationship with the targeted individuals or entities. ${ }^{53}$ The targeted names were made available. ${ }^{54}$ The banks who already had such relationships with designated individuals or entities were not asked to break off such relationships immediately, but they were required to declare promptly the nature of such relationships to the Swiss Foreign Ministry.

During the escalation phase, the Swiss measures became more aligned with those of the EU. First, more names were added to the targeted sanction list that had been established in the initial phase. While more names of separatists were added to the target list during the escalation phase, Russian officials and military leaders were equally targeted. A number of trade restrictions were also set up: $:^{55}$ restrictions on the export of dual-use and military goods to Russia; restrictions on the export of certain goods used for the extraction of oil in deep sea, Arctic, 
or shale gas projects in Russia; and certain restrictions on exports to, and imports from, Crimea. By 2015, Switzerland had integrated the EU's principal restrictive measures into its own sanction regime. ${ }^{56}$ All investments in Crimea and Sevastopol were now prohibited, and the ban on the export of several key goods to the region was strengthened. ${ }^{57}$

Despite this alignment with the sanctions imposed on Russia by other States, the basic attitude of Switzerland has remained the same since the initial phase: it is not particularly enthusiastic about the sanctions. Unlike its own sanctions against North Korea, Iran, or Syria, the measures regarding Russia and Ukraine are not even called "sanctions" in the Swiss legislative instruments. ${ }^{58}$ The principal aim of the measures taken by Switzerland with regard to Russia is to prevent the circumvention of the sanctions via Switzerland. ${ }^{59}$ It is explicit in its intention not to adopt the EU sanctions against Russia as its own. ${ }^{60}$ While the EU emphasizes the importance of the maintenance and further improvement of the Swiss voluntary alignment regarding the EU sanctions on Russia, ${ }^{61}$ the need for further improvement is not apparent in the eyes of Switzerland, either; its current measures to avoid circumvention are complied with, and there is no indication of actual circumventions of the EU sanctions on Russia via Switzerland. ${ }^{62}$ The Swiss measures are based on its Law on the Embargos 2002 that allows Switzerland to "enact compulsory measures in order to implement sanctions that have been ordered by the United Nations Organisation, by the Organisation for Security and Cooperation in Europe or by Switzerland's most significant trading partners. . . (Art. 1(1))."

\section{(2) Japan}

Japan is a State whose measures against Russia look even more half-hearted than Switzerland's. Japan joined the sanction efforts in the initial phase by establishing its own travel bans for 23 individuals. ${ }^{63}$ However, these 23 names remained unavailable to the public. These individuals would only learn that they were being targeted if they attempted to travel to Japan. Only in the escalation phase of summer 2014 did Japan add the asset freeze to its targeted sanction regime, and it made the names of 40 individuals and two entities public. ${ }^{64}$ These targeted individuals were individuals from Crimea or separatists from Eastern Ukraine, not Russian politicians or businessmen. ${ }^{65}$

During the escalation phase, Japan did implement a few economic sanctions in relation to Russia, mostly as a response to the shooting down of a Malaysian Airlines flight over Eastern Ukraine: export restrictions on weapons and measures to prevent the issuing of securities by designated Russian banks and their subsidiaries, ${ }^{66}$ in accordance with its Foreign Exchange and Foreign Trade Act 1949. It also established a trade restriction in relation to Crimea and Sevastopol. ${ }^{67}$ However, unlike the EU restrictive measures or the US sanctions in relation to Crimea and Sevastopol, the Japanese measure consists of an import ban only; no restriction is envisaged for exports to, or investments in, the Crimean Peninsula. 


\section{(3) New Zealand}

Another State that can be described as quite unenthusiastic is New Zealand. In the initial phase, like Switzerland, the government suspended its negotiation of the free trade agreement with Russia. ${ }^{68}$ The foreign minister did announce the establishment of a travel ban against "roughly 20 " individuals ${ }^{69}$ without making the names public. He is quoted as admitting that "it would not look good if, at a time when others were putting in place sanctions, particularly in Europe, to demonstrate their concerns, New Zealand was to not be in step, but it is largely symbolic." ${ }^{\prime 70}$ In the absence of any sanction measures regarding trade and investment, the political leaders of New Zealand even had to remind its corporations not to "exploit the gap left by other countries" trade sanctions on Russia."”1

\section{Questions of legality and effectiveness}

The questions of legality and effectiveness can further highlight several distinctive features of the sanctions on Russia. On the one hand, as these sanctions are autonomous sanctions, the question of legality can obviously be raised, especially in the face of the Russian determination to discredit the legitimacy of these sanctions and to refute their legality (III.1). On the other hand, addressing the question of effectiveness is rather futile if it is an inquiry into changes in the Russian conduct regarding Crimea and Eastern Ukraine. There have been none. Rather, the question addressed will be that of implementation and compliance, that is, whether these sanctions designed and put into place by the EU and other States are being carried out to the letter (III.2(1)). The question of effectiveness could also be addressed, not so much as a question of coercive diplomacy but as one of nonrecognition policy in the present case (III.2(2)).

\section{Question of legality of the sanctions on Russia}

The question of legality could have been minimized if the sanctions on Russia had been demanded, authorized, or recommended by the UN Security Council. However, there has been no such demand, authorization, or recommendation in the present case; therefore, the question of the legality of these autonomous sanctions must be addressed.

\section{(1) Sanctions as reactions to the breach of obligations erga omnes}

The sanctions on Russia are imposed in order to coerce it to change its attitude regarding Crimea and Eastern Ukraine. In this light, the sanctions against Russia constitute a tool of coercive diplomacy designed to interfere with the decisions and policies of a sovereign State. Thus, one could, in abstracto, question the legality of these actions in the light of a well-established principle of nonintervention (noninterference).${ }^{72}$ However, in the present case, the EU and other States are trying to interfere with the Russian policy to maintain its unlawful claim on Crimea as 
its own and its policy to remain involved in the destabilization of Eastern Ukraine, a part of a territory of another sovereign State. These Russian policies and actions are, prima facie, violations of international law. Since the economic sanctions are reactions to these violations, and since these are measures that seek the cessation of these violations, a potential tool of justification for the sanctions, outside of specific treaties, in the assessment of their legality would be countermeasures. ${ }^{73}$

Incidentally, countermeasures could shed further light on the legitimacy of the sanctions on Russia by those who do not directly suffer from the Russian wrongdoing. Ukraine's own sanctions against Russia could be justified as straightforward countermeasures even if they involved unlawful acts: when an injured State reacts to the State responsible for an internationally wrongful act, it is a classic scenario of taking a countermeasure. In this light, compared to Ukraine, the standing that the EU, the United States, or any State other than Ukraine may have in imposing sanctions may not be as apparent. Even though the sanctions are reactions to the annexation of Crimea and the destabilization of Eastern Ukraine at the expense of Ukrainian sovereignty, one may question the legality and the legitimacy of the reactions in the present case that are not coming from Ukraine, the injured State.

A key to understanding the issue of standing lies in the nature of the violations by Russia that prompted the sanctions. The annexation of Crimea and the further destabilization of Eastern Ukraine by Russia are largely seen by the international community as a violation of the prohibition on the use of force, ${ }^{74}$ a peremptory norm of international law. Moreover, the obligation breached is not a bilateral obligation that Russia owes to Ukraine alone. It is one of obligations erga omnes, that is, "the obligations of a State towards the international community as a whole" which are "the concern of all States' and for whose protection all States have a "legal interest." "75 This makes the theory of "third party countermeasures" quite relevant. ${ }^{76}$ While the ILC Articles on State Responsibility made a very prudent assessment regarding third-party countermeasures, ${ }^{77}$ articulating the obligation erga omnes and the concept of third-party countermeasures helps reaffirm the legitimacy of the sanctions imposed by those who are not directly attacked or injured by the initial wrongful act. The international community does not seem to reject the third-party countermeasures as reactions to violations of certain types of erga omnes obligations. ${ }^{78}$

\section{(2) From the Russian perspective: Rejection of the legality of the sanctions}

The source of legitimacy of the established sanctions is the nature of Russia's actions in 2014 and onwards, which violated a peremptory norm of international law. This, however, is a characterization of events that Russia refutes, as was shown in Section I. In the eyes of Russia, there is no violation to speak of in the first place. Any reference to countermeasures is, therefore, irrelevant and there is no legitimacy in the sanctions. On the contrary, many sanctions are, so contends Russia naturally, unlawful in the light of multilateral or bilateral treaties it has with the EU or the States that have imposed sanctions on Russia. 
For example, Russia tried to discredit the legitimacy of the EU and US trade restrictions in light of the World Trade Organization (WTO) agreements. The EU, the United States, and Russia are all members of the WTO. Hence, measures that restrict their trade can be evaluated and can eventually be deemed unlawful in light of the principles of free trade within the WTO. When the EU and the United States intensified their sanctions in the escalation phase of the crisis, the Russian President criticized these sanctions as WTO violations. ${ }^{79}$ However, Russia did not initiate any formal process of dispute settlement within the WTO against the EU or the United States. Thus, the alleged wrongfulness of these sanctions in light of the WTO agreements remains, to date, an allegation made by Russia without confirmation. ${ }^{80}$ Accordingly, the scope of the security exceptions in Article XXI(b) GATT with respect to autonomous sanctions, such as those in the present case, remains untested within the WTO. ${ }^{81}$ One of these security exceptions concerns a measure by a WTO Member that "it considers necessary for the protection of its essential security interests," which is "taken in time of war or other emergency in international relations." 82 Regarding the sanctions against Russia, there was a case in which this particular security exception in Article XXI(b) GATT was briefly examined. In that case, which was brought to the General Court of the European Union by Russian companies,${ }^{83}$ the General Court indicated that "even if GATT were directly applicable and could usefully be relied on by the applicants in the present case," ${ }^{\prime 4}$ the EU restrictive measures in question could fall under the security exceptions in Article XXI GATT. It rejected the applicants' plea that these autonomous sanctions by the EU were contrary to the EU's obligations in light of the GATT/WTO. ${ }^{85}$

Russia also attempted to refute the legitimacy of the trade restrictions outside the WTO. This effort took a form of countersanctions as a response to the reinforcement of the autonomous sanctions in the escalation phase. The Russian countersanctions announced on August 6, 2014, consisted of an import ban on agro-food products, initially implemented for a year. ${ }^{86}$ These countersanctions were applicable to imports from, inter alia, the EU, the United States, Japan, Canada, and Australia. The main categories that were targeted were fruit, vegetables, meat, fish, and dairy products. The measures were based on Federal Law No. 281-FZ "On Special Economic Measures" (December 30, 2006) and Federal Law No. 390-FZ "On Security" (December 28, 2010). From the EU's side, Poland expressed the view that the Russian import ban on agro-food products as a countersanction should be a subject of complaint in the WTO. ${ }^{87}$ When approached by Poland, the EU, however, did not initiate any formal process against Russia within the WTO.

The Russian side attempted to question the legitimacy and legality of the sanctions in light of other treaties, too. For example, Rosneft, a Russian oil company, tried to do so through a reference to the EU-Russia Cooperation and Partnership Agreement (CPA). This is an instrument that facilitates EU-Russia relations, including trade. Rosneft alleged that several provisions in Council Decision 2014/512 and Council Regulation 833/2014, the restrictive measures that the EU adopted in the escalation phase, were incompatible with the EU-Russia CPA. The case was referred to the Court of Justice of the EU. ${ }^{88}$ 
The Court of Justice rejected Rosneft's argument. Instead of examining the substantive provisions of the EU-Russia CPA, it pointed out that the EU-Russia CPA had a provision regarding exceptions. Article 99 of the EU-Russia CPA, which, in fact, resembles the security exceptions provided in Article XXI GATT, reads:

Nothing in this Agreement shall prevent a Party from taking any measures:

1. which it considers necessary for the protection of its essential security interests:

(a) ...; (b) . . ; (c) . .;

(d) in the event of serious internal disturbances affecting the maintenance of law and order, in time of war or serious international tension constituting threat of war or in order to carry out obligations it has accepted for the purpose of maintaining peace and international security.

There was, therefore, no need to examine the compatibility between the EU restrictive measures in question and the EU-Russia CPA, for the agreement itself permitted the adoption of restrictive measures even if they were not compatible with the EU-Russia CPA. ${ }^{89}$ The situations enumerated in Article 99 of the EURussia CPA, "in time of war or serious international tension constituting threat of war," were not limited to situations that directly affected the EU. ${ }^{90}$ Given the circumstances and the Council's broad discretion in this area, the Council could take the view that these restrictive measures were indeed necessary for the protection of the essential security interests of the EU within the meaning of Article 99. ${ }^{91}$ Thus, the examination of the Council actions in question in the light of the EU-Russia CPA did not reveal anything that could affect their validity. ${ }^{92}$

\section{Question of effectiveness of the sanctions on Russia}

\section{(1) Implementation: Breaches and evasions}

There have been numerous instances of breaches and evasions. In July 2017, ExxonMobil was fined in the United States for its dealings with Igor Sechin of Rosneft, a prominent individual identified in the US targeted sanctions. ${ }^{93}$ In November 2017, a Dutch shipping company was fined for carrying military items in transit that were ultimately bound for Russia, ${ }^{94}$ breaching the EU restrictive measures. With regard to the construction of the bridge between Russia and Crimea referred to in the introduction to this chapter, several Dutch construction companies are being investigated for possible violations of the EU restrictive measures. ${ }^{95}$ Siemens, a German engineering corporation, brought a case to a court in Russia against Russian firms because of a sanction breach that occurred in its transaction with them. 
The last case regarding Siemens is a good illustration of a difficulty that sanctions on Russia might face. Siemens had a contract with a Russian firm regarding its gas turbines for a power plant. In summer 2015, there were allegations that Siemens was supplying these gas turbines for the construction of a power plant in Crimea. The transfer of turbines to Crimea, if the allegations turned out to be true, would constitute a violation of the EU restrictive measures imposing a partial embargo on the energy sector in Crimea, as described in II.1.

At the time, Siemens denied these allegations and stated without any ambiguity that "Siemens respects the decisions regarding sanctions and will, of course, abide by the current sanction provisions." 96 According to Siemens, the gas turbines were meant for a power plant that was being built in Russia, not Crimea. However, by September 2016, Siemens itself became suspicious of the destination of its gas turbines, and it suspended deliveries of the rest of the individual components. By July 2017, Siemens was forced to admit that its gas turbines had, in fact, been transferred to Crimea, without its knowledge or consent. This development was, according to Siemens, "a blatant breach of Siemens' delivery contracts, trust and EU regulations." ${ }^{97}$ While the contracts in question were not made public, it was emphasized that they prohibited the delivery of the gas turbines to Crimea. Siemens, in the firm belief that there had been a breach of the contracts by its Russian business partners, who had brought lawsuits against them in the Moscow Arbitration Court. The purpose of the lawsuits was to force these companies to return the gas turbines to their original destination outside Crimea. Predictably, the Moscow Arbitration Court turned down this request. ${ }^{98}$

The limitations of the EU's efforts to ensure compliance with the sanctions in a case such as this are apparent. The EU restrictive measures are applicable to EU corporations but not to Russian corporations unless they carry out their business within the EU. Thus, an action carried out, or a decision made, by a Russian corporation cannot be prosecuted or fined by the EU's national authorities in the way a breach by an EU corporation would be. All the EU could do in this case was to add a few individuals and entities deemed responsible for, or involved in, the transfer of the gas turbines to its list of targeted sanctions. ${ }^{99}$ For Siemens, turning to a court in Russia was the only realistic option in seeking a remedy regarding this contract breach. However, Russia is the very State on which the EU sanctions are imposed, and it is the State that most vehemently rejects the legitimacy of these sanctions. Its judicial branch is very unlikely to recognize a contract breach that would be tantamount to upholding the EU sanctions or recognizing their legitimacy. ${ }^{100}$

Regarding the sanctions on Russia in general, when breaches and evasions are examined, the limitations of the autonomous sanctions also become apparent. Because they are autonomous sanctions, monitoring for compliance is undertaken by journalists, NGOs, and Ukraine whenever it is possible and not systematically by any international organizations. There is no help from the Sanctions Committee or the Panel of Experts as in the case of, for example, embargoes against North Korea under the UN sanctions. As was explained previously, the EU has imposed a partial export ban on Crimea in addition to a complete import ban from that 
area. The commercial ships flying the flags of EU Member States must not carry these prohibited goods to Crimea, regardless of whether the prohibited goods have originated in their territories. However, aided by the commercial practice known as "flag of convenience," which allows ship owners to register their ships in countries other than their own, the embargo can easily be circumvented. A significant number of vessels traveling to Crimea have, since the EU sanctions were put in place, changed their flags so that they now fly Russian flags. Incidents of the similar kind for commercial ships going to North Korea would be detected and followed up on closely by the Sanctions Committee or the Panel of Experts. ${ }^{101}$ There is no parallel institutional monitoring or supervision for ships destined for Crimea.

\section{(2) Nonrecognition policy}

Given the main task of economic sanctions, which is to be a tool for coercive diplomacy, ${ }^{102}$ it is only right to conclude that the sanctions on Russia since March 2014 have not been effective. In the present case, however, there is another aspect to assess, which is quite independent from how coercive these sanctions are or can be. The sanctions on Russia constitute a message that those who impose them do not recognize the annexation of Crimea. They are not only a tool for coercive diplomacy but also for nonrecognition policy. ${ }^{103}$ These sanctions ensure that "ex injuria non oritur jus" is not an empty phrase but remains true in practice. Regardless of their effectiveness as coercive measures, the sanctions in place help to prevent the treatment of the situation as a fait accompli. One could say that these sanctions are meaningful even if they are not effective, and therefore they are different from the sanctions against Syria, North Korea, and Iran discussed previously in this book.

Both the EU and the United States are very vocal about their nonrecognition policies on the annexation of Crimea. From the initial phase of the crisis, the EU has "strongly condemned the illegal annexation of Crimea and Sevastopol to the Russian Federation and will not recognise it." 104 The EU has been very consistent about this condemnation since then. The United States has also repeatedly stated, in connection with its sanctions, that "[T]his action [Imposing sanctions] underscores the U.S. government's opposition to Russia's occupation of Crimea and our firm refusal to recognize its attempted annexation of the peninsula." ${ }^{105}$ In fact, there is a remarkable unity regarding this nonrecognition message among those who impose sanctions on Russia, in contrast to considerable differences observed in both the degree of enthusiasm and actual design, as previously discussed.

This unique characteristic of the sanctions on Russia also means that there is very little flexibility regarding the time frame to lift the sanctions. Though one could envision a partial withdrawal of sanctions when the demands regarding the "Minsk II" implementation are met, the only logical, full exit is to lift the sanctions when Crimea is returned to Ukraine. This exit strategy has indeed been confirmed by the very States that maintain the sanctions: "Our Crimea-related sanctions will remain in place until Russia returns control of the peninsula to Ukraine."106 


\section{Concluding remarks}

From the Ukrainian perspective, letting the situation remain frozen and forgotten by the international community is a scenario that must be avoided. Accordingly, Ukraine currently fights Russia with all available tools of diplomacy. It actively uses all kinds of courts of law to make itself heard. Capitalizing on the compulsory dispute settlement procedure under Annex VII to the United Nations Convention on the Law of the Sea (UNCLOS), Ukraine instituted a case against Russia in the Permanent Court of Arbitration, by formulating the case as a dispute concerning coastal State rights in the Black Sea, Sea of Azov, and Kerch Strait. ${ }^{107}$ Capitalizing on Article 13(2) of the Rome Statute of the International Criminal Court (ICC), Ukraine has made a declaration to accept the ICC's jurisdiction regarding the incidents and events since February 2014. ${ }^{108}$ Capitalizing on the interstate complaint system within the European Convention on Human Rights, Ukraine has lodged multiple complaints against Russia regarding incidents in Eastern Ukraine and Crimea since 2014. ${ }^{109}$ Ukraine has also submitted a case against Russia to the International Court of Justice, which produced a decision on provisional measures in 2017. ${ }^{110}$ The autonomous sanctions on Russia must accompany these efforts by Ukraine. The sanctions constitute the strongest tool and the clearest sign of the international community's nonrecognition policy toward the annexation and the conflict. Though their limit as a tool of coercive diplomacy is apparent, in the absence of the Security Council's involvement, the autonomous economic sanctions are the best support the international community can extend to Ukraine in this conflict.

\section{Notes}

* This work was supported by a research grant by the Japan Society for the Promotion of Science (2016-2021).

1 Press Statement by the British Foreign Office, "FCO Statement on Opening of Kerch Bridge," (May 15, 2018), available at <www.gov.uk/government/news/ fco-statement-on-opening-of-kerch-bridge>.

2 Press Statement by the US Department of State, "The Opening of the Kerch Bridge in Crimea," (May 15, 2018), available at <www.state.gov/the-opening-of-the-kerchbridge-in-crimea/ $>$. In the statement, the bridge is also condemned because of the way it "impedes navigation by limiting the size of ships that can transit the Kerch Strait, the only path to reach Ukraine's territorial waters in the Sea of Azov."

3 Facebook post by the Russian Embassy in the United States (May 15, 2018), available at $<$ www.facebook.com/RusEmbUSA/posts/786288694914856>, as a response to the US press statement, supra note 2.

4 Press Statement by the British Foreign Office, supra note 1.

5 See U.N. Doc. A/RES/68/262 (March 27, 2014); and U.N. Doc. S/PV.7138 (March 15, 2014).

6 Address by the President of the Russian Federation (March 18, 2014), available at $<$ http://en.kremlin.ru/events/president/news/20603>.

7 Being one of the five permanent members of the UN Security Council, Russia prevented the Security Council from adopting a resolution (U.N. Doc. S/2014/189 (March 15, 2014)). The General Assembly was able to adopt a resolution entitled "Territorial integrity of Ukraine" (U.N. Doc. A/RES/68/262, supra note 5), with 100 in favor, 11 against, 58 abstentions, and 24 non-voting. 


\section{Mika Hayashi}

8 "Agreement on the Accession of the Republic of Crimea to the Russian Federation Signed," (March 18, 2014), available at <http://en.kremlin.ru/events/president/ news/20604>. See also Thomas D. Grant, "Annexation of Crimea," American Journal of International Law, Vol. 109, No. 1 (2015), pp. 70-71.

9 U.N. Doc. S/PV.7144 (March 19, 2014).

10 U.N. Doc. S/PV.7154 (April 13, 2014); U.N. Doc. S/PV.7157 (April 16, 2014); U.N. Doc. S/PV.7165 (April 29, 2014); and U.N. Doc. S/PV.7167 (May 2, 2014).

11 See Thomas D. Grant, "Armed Force in Aid of Sucession," Revue de Droit Militaire et de Droit de la Guerre, Vol. 53, No. 1 (2014), p. 72.

12 According to a press release of the ICRC, the situation was a non-international armed conflict. "Ukraine: ICRC Calls on All Sides to Respect International Humanitarian Law,"News Release 14/125 (July 23, 2014), available at $<$ www.icrc.org/eng/resources/ documents/news-release/2014/07-23-ukraine-kiev-call-respect-ihl-repatriate-bodiesmalaysian-airlines.htm>. The Office of the Prosecutor of the International Criminal Court is of the view that the situation reached the level of non-international armed conflict as early as April 2014. Office of the Prosecutor, Report on Preliminary Examinations Activities 2016, para. 168.

13 U.N. Doc. S/PV.7253 (August 28, 2014).

$14 \mathrm{Ibid}$. On the subsequent admissions of Russia, see Théodore Christakis, "SelfDetermination, Territorial Integrity and 'Fait Accompli' in the Case of Crimea," Zeitschrift für ausländisches öffentliches Recht und Völkerrecht, Vol. 75, No. 1 (2015), p. 75.

15 U.N. Doc. S/Res/2166 (July 21, 2014).

16 A joint investigation team concluded in May 2018 that the Russian missile was indeed responsible for the shooting. See the Security Council discussion regarding this conclusion, U.N. Doc. S/PV.8270 (May 29, 2018).

17 See the Dutch government's position, "MH17: The Netherlands and Australia Hold Russia Responsible," (May 25, 2018), available at <www.government.nl/latest/ news/2018/05/25/mh17-the-netherlands-and-australia-hold-russia-responsible $>$; and the Australian foreign ministry's media release, "Holding Russia Responsible for Its Role in the Downing of MH17," (May 25, 2018), available at $<$ https://foreignminister.gov.au/ releases/Pages/2018/jb_mr_180525c.aspx $>$.

18 U.N. Doc. S/PV.8270 (May 29, 2018), supra note 6.

19 The text is reproduced in Annex I to the letter dated February 24, 2015, from the Permanent Representative of Ukraine to the United Nations addressed to the President of the Security Council, U.N. Doc. S/2015/135 (May 9, 2015). The ceasefire agreement was welcomed by several Security Council members, U.N. Doc. S/PV.7269 (September 19, 2014).

20 These "elections" were discussed by the Security Council in U.N. Doc. S/PV.7311 (November 12, 2014).

21 See the descriptions in the letter dated November 5, 2014, from the Permanent Representative of Ukraine to the United Nations addressed to the President of the Security Council, U.N. Doc. S/2014/792 (November 5, 2014).

22 The text of the agreements is reproduced in Annex I of U.N. Doc. S/Res/2202 (February 17, 2015).

23 Joint press point with NATO Deputy Secretary General Rose Gottemoeller and the Prime Minister of Ukraine, Volodymyr Groysman (February 9, 2017), available at $<$ www.nato.int/cps/en/natohq/opinions_140847.htm>.

24 OSCE Special Monitoring Mission to Ükraine (last visited on August 22, 2018), available at $<$ www.osce.org/special-monitoring-mission-to-ukraine $>$.

25 Tom Burridge, "Ukraine Conflict: Daily Reality of East's 'Frozen War'," BBC News (April 15, 2016), available at <www.bbc.com/news/world-europe-35990401>. Thomas D. Grant, "Three Years After Annexation: Of 'Frozen Conflicts' and How to Characterise Crimea," German Yearbook of International Law, Vol. 59 (2016), 
pp. 49-79 (though Grant's definition of "frozen conflicts" does not include Crimea in his frozen conflicts).

26 Both groups of States are representative States and do not comprehensively include all States that participate in the sanction efforts against Russia.

27 "Restrictive measures" is a term used within the EU. For a general discussion of these measures by the EU, see Chapter 7 on "Implementation of Sanctions: European Union."

28 As a diplomatic measure, the EU canceled the EU-Russia summit planned in 2014. It also suspended the negotiations to update the EU-Russia Partnership and Cooperation Agreement currently in place. Dramatic as they were, these measures were clearly retorsions, the legality of which requires no further analysis.

29 Council Decision 2014/145/CFSP (March 17, 2014).

30 For more details on this incident, see Section III.2.

31 Council Decision 2018/1085/CFSP (July 31, 2018); and Regulation 2018/1072 (July 31,2018 ). See the introduction of this chapter for the international reactions to this construction of the bridge.

32 As of June 2019, the list is in place until September 2019.

33 Council Decision 2014/512/CFSP (July 31, 2014).

34 As of June 2019, the current sanctions are in place until the end of July 2019.

35 Council Decision 2014/386/CFSP (June 23, 2014).

36 Council Decision 2014/507/CFSP (July 30, 2014).

37 Council Decision 2014/933/CFSP (December 18, 2014).

38 As of June 2019, the measures are in place until June 23, 2019.

39 News article by the US Department of Defense, "DOD Puts Military-to-military Activities With Russia on Hold," (March 3, 2014), available at $<$ http://archive.defense.gov/ news/newsarticle.aspx?id $=121759>$.

40 Executive Order 13660, "Blocking Property of Certain Persons Contributing to the Situation in Ukraine," (March 6, 2014). For a detailed analysis of the Executive Orders for the sanctions against Russia, including E.O. 13660, see Alexandra Hofer, "The 'Curiouser and Curiouser' Legal Nature of Non-UN Sanctions: The Case of the US Sanctions against Russia," Journal of Conflict and Security Law, Vol. 23, No. 1 (2018), pp. $75-104$.

41 Executive Order 13660, supra note 40.

42 Press release, "Announcement of Additional Treasury Sanctions on Russian Government Officials and Entities," (April 28, 2014), available at <www.treasury.gov/press-center/ press-releases/Pages/j12369.aspx>.

43 Press release, "Announcement of Treasury Sanctions on Entities Within the Financial Services and Energy Sectors of Russia, Against Arms or Related Materiel Entities, and Those Undermining Ukraine's Sovereignty," (July 16, 2014), available at <www. treasury.gov/press-center/press-releases/Pages/j12572.aspx>; see also Executive Order 13661, "Blocking Property of Additional Persons Contributing to the Situation in Ukraine," (March 17, 2014).

44 Press release of the Treasury Department, supra note 43; see also Executive Order 13662, "Blocking Property of Additional Persons Contributing to the Situation in Ukraine," (March 21, 2014).

45 Executive Order 13685, "Blocking Property of Certain Persons and Prohibiting Certain Transactions with Respect to the Crimea Region of Ukraine," (December 19, 2014).

46 For example, the additional sanctions were adopted in 2016 in response to alleged Russian meddling in the US presidential election campaign.

47 Special Economic Measures (Ukraine) Regulations (SOR/2014-60); and Special Economic Measures (Russia) Regulations (SOR/2014-58).

48 Justice for Victims of Corrupt Foreign Officials Regulations (SOR/2017-233). 
49 Foreign Minister's remark at $A B C R N$ Breakfast (March 18, 2018), available at $<$ https://foreignminister.gov.au/transcripts/Pages/2018/jb_tr_180316.aspx?w=tb1CaG pkPX $\% 2$ FlS0K $\% 2 \mathrm{Bg} 9 \mathrm{ZKEg} \% 3 \mathrm{D} \% 3 \mathrm{D}>$.

50 Paul Osborne, "Australia Steps up Russia Sanctions," Sidney Morning Herald (September 1, 2014), available at <www.smh.com.au/national/australia-steps-up-russiasanctions-20140901-3eokf.html>.

51 These measures included a suspension of the negotiation of its free trade agreement with the Russia/Belarus/Kazakhstan customs union and a suspension of its military cooperation in the form of letting Russian personnel train in its territory. "La Suisse ne s'associe pas aux sanctions contre la Russie," Le matin (March 26, 2014), available at $<$ www. lematin.ch/suisse/La-Suisse-ne-s-associe-pas-aux-sanctions-de-lUE-et-des-USA/ story/12495892>.

52 Ibid.

53 Ordonnance instituant des mesures visant à empêcher le contournement instituant des mesures visant à empêcher le contournement (April 2, 2014).

54 Names in the targeted sanctions in relation to the situation in Ukraine are made public on the Foreign Ministry's website (last visited on August 22, 2018), available at $<$ www. seco.admin.ch/seco/fr/home/Aussenwirtschaftspolitik_Wirtschaftliche_Zusammenarbeit/Wirtschaftsbeziehungen/exportkontrollen-und-sanktionen/sanktionen-embargos/ sanktionsmassnahmen/massnahmen-zur-vermeidung-der-umgehung-internationalersanktione.html>.

55 Ordonnance instituant des mesures visant à empêcher le contournement de sanctions internationales en lien avec la situation en Ukraine (August 27, 2014).

56 See the press release "Situation in Ukraine: Federal Council Extends Measures to Prevent the Circumvention of Sanctions," (March 6, 2015), available at <www.admin.ch/ gov/en/start/dokumentation/medienmitteilungen.msg-id-56478.html>.

57 Ordonnance instituant des mesures visant à empêcher le contournement de sanctions internationales en lien avec la situation en Ukraine (March 6, 2015).

58 Ordonnances regarding sanctions against Iran, Syria, or North Korea are about "measures against" these States, whereas the ordonnances regarding Ukraine and Russia are about "measures that purport to prevent the circumvention of sanctions" (see, e.g., ordonnances cited in supra notes 53,55, and 57), and the usage of this distinct expression is consistent throughout the Swiss diplomacy. See, e.g., Conseil fédéral, Rapport sur la politique économique extérieure 2017 et Rapport sur les mesures tarifaires prises en 2017 (January 10, 2018) or the press release "Situation in Ukraine," supra note 56.

59 Conseil fédéral, supra note 58, p. 845.

$60 \mathrm{Ibid}$. "Le Conseil fédéral poursuit sa politique consistant à ne pas faire siennes les sanctions prononcées par l'UE à l'égard de la Russie, mais à empêcher le contournement des sanctions via la Suisse."

61 Press release, "Council Conclusions on EU Relations with the Swiss Confederation," (February 28, 2017), available at <www.consilium.europa.eu/en/press/ press-releases/2017/02/28/conclusions-eu-swiss-confederation/>.

62 Conseil fédéral, supra note 59, p. 845.

63 "Statement by the Minister for Foreign Affairs of Japan on the Sanctions Against Russia Over the Situation in Ukraine," (April 29, 2014), available at <www.mofa.go.jp/ press/release/press4e_000281.html>.

64 "Measures to Freeze Assets of Those Who Are Considered to Be Directly Involved in 'Annexation' of the Autonomous Republic of Crimea and the City of Sevastopol or Destabilization of Eastern Part of Ukraine," (August 5, 2014), available at $<$ www. mofa.go.jp/press/release/press4e_000387.html>. Note that Japan timidly puts the word "annexation" in quotation marks on this webpage.

$65 \mathrm{Ibid}$. A single exception in the list was the Deputy Commander of the Black Sea Fleet of the Russian Navy. 
66 Ministry's press release, "Tightening of Export Restrictions on Arms and Dual-use Goods for Military Use to the Russian Federation and Prohibitive Measure of Issue of Securities by Designated Russian Federation Banks and their Subsidiaries," (September 24, 2014), available at <www.mofa.go.jp/press/release/press4e_000446.html>.

67 "Statement by the Minister for Foreign Affairs of Japan on the Additional Measures Over the Situation in Ukraine," (July 28, 2014), available at <www.mofa.go.jp/press/ release/press2e_000003.html>.

68 According to the Foreign Ministry, “[O]n 9 November 2010, New Zealand, Russia, and the then Customs Union partners of Belarus and Kazakhstan agreed to start negotiations on a comprehensive and modern free trade agreement (FTA). Significant progress had been made; however, the negotiations were suspended in 2014 following events in the Ukraine," available at <www.mfat.govt.nz/en/countries-and-regions/ europe/russia/> (accessed May 31, 2018).

69 Audrey Young, "NZ Announces 'Modest' Sanctions Over Crimea Seizure," New Zealand Herald (March 23, 2014), available at <www.nzherald.co.nz/nz/news/article. cfm?c id $=1 \&$ objectid $=11224828>$.

70 Audrey Young, "Sanctions Against Russia Symbolic, McCully Admits," New Zealand Herald (March 24, 2014), available at <www.nzherald.co.nz/nz/news/article. cfm?c_id=1\&objectid=11224957>.

71 Claire Trevett, "Exploiting Russia Sanctions 'a Bad Look'," New Zealand Herald (November 17, 2014), available at <www.nzherald.co.nz/business/news/article. cfm?c id $=3$ \&objectid $=11359580>$.

72 Economic sanctions in the light of the principle of nonintervention are discussed in Natalino Ronzitti, "Sanctions as Instruments of Coercive Diplomacy: An International Law Perspective," in Natalino Ronzitti ed., Coercive Diplomacy, Sanctions and International Law (Brill, Nijhoff, 2016), pp. 3-9; and Alexander Orakhelashvili, "Sanctions and Fundamental Rights of States: The Case of EU Sanctions Against Iran and Syria," in Matthew Happold and Paul Eden eds., Economic Sanctions and International Law (2016), pp. 16-20 and 34-36.

73 Chapter 1 on "Definition and Legal Justification of Sanctions"; ILC Articles on Responsibility of States for Internationally Wrongful Acts, Articles 49-53.

74 See the criticism voiced in the Security Council meetings, supra notes 10 and 13. This is how the case is analyzed by international lawyers, too. See, e.g., Christakis, supra note 14, pp. 96-99; Grant, supra note 11, pp. 84-93; and Mary Ellen O'Connell, “The Crisis in Ukraine - 2014," in Tom Ruys et al. eds., The Use of Force in International Law: A Case-based Approach (2018), pp. 860-871.

75 Jochen A. Frowein, "Obligations erga omnes," Max Planck Encyclopedia of Public International Law (December 2008), available at $<\mathrm{https} / / /$ opil.ouplaw.com/home/ epil>.

76 In general, see Christian J. Tams and Alessandra Asteriti, "Erga Omnes, Jus Cogens and Their Impact on the Law of Responsibility," in Malcolm Evans and Panos Koutrakos eds., The International Responsibility of the European Union (2013), pp. 172-177. For an examination of the US sanctions against Russia as third-party countermeasures, see Hofer, supra note 40, pp. 21-25.

77 See the ILC Articles on Responsibility of States for Internationally Wrongful Acts, Art. 54, and the commentary on this article; for a discussion of the sanctions of the EU as those of an international organization, see a parallel, cautious approach adopted in the ILC Draft Articles on the Responsibility of International Organizations, art. 57, albeit the limitation that this article only deals with actions against another international organization.

78 Christian J. Tams, Enforcing Obligations "Erga Omnes" in International Law (2005), pp. 207-249.

79 “Putin Says US, EU Sanctions Violate WTO,” Deutsche Welle (September 18, 2014), available at <www.dw.com/en/putin-says-us-eu-sanctions-violate-wto/a-17932934>. 


\section{Mika Hayashi}

80 Rostam J. Neuwirth and Alexandr Svetlicinii, "The Economic Sanctions Over the Ukraine Conflict and the WTO: 'Catch-XXI' and the Revival of the Debate on Security Exceptions," Journal of World Trade, Vol. 49, No. 5 (2015), pp. 894-895.

81 Meanwhile, Russia's recourse to the security exceptions in Article XXI(b) GATT regarding its own measures on the traffic in transit from Ukraine, when Ukraine brought its complaint to a WTO Panel, was upheld by the Panel (see WT/DS512/R (April 9, 2019)).

82 Article XXI(b)(iii) GATT. Regarding the potential role of the security exceptions in art. XXI(b) GATT for autonomous sanctions, see Andrew D. Mitchell, "Sanctions and the World Trade Organisation," in Larissa van den Herik ed., Research Handbook on UN Sanctions and International Law (2017), pp. 292-303.

83 Case 715-14 (September 13, 2018).

84 Ibid., para. 180.

85 Ibid., paras. 182-183.

86 For information on the Russian countersanctions, see Neuwirth and Svetlicinii, supra note 80, pp. 901-903. Russia also reportedly countered the targeted sanctions by implementing its own travel bans. The Russian list for the travel ban targeting the EU leadership was said to include 89 names of European politicians and military leaders. "European Union Anger at Russian Travel Blacklist," BBC News (May 31, 2015), available at $<$ www.bbc.com/news/world-europe-32949236>.

87 "Poland Asks EU to Complain to WTO Over Russian Embargo," Reuters (August 19, 2014), available at <www.reuters.com/article/us-ukraine-crisis-poland-wto/polandasks-eu-to-complain-to-wto-over-russian-embargo-idUSKBN0GJ1GU20140819>.

88 Case 72-15 (March 28, 2017). This was a preliminary ruling under Article 267 of the Treaty on the Functioning of the EU (TFEU), requested by the High Court of Justice (England \& Wales), Queen's Bench Division.

89 Ibid., para. 110.

90 Ibid., para. 112.

91 Ibid., paras. 113-116.

$92 \mathrm{Ibid}$., para. 117. The question of the EU-Russia CPA was also brought to the General Court of the EU in Case 715-14, supra note 83. Citing the evaluation of the Court of Justice (para. 178), the General Court confirmed that "no new argument has been put forward by the applicants [Rosneft and others] before this Court that might call in question that conclusion" (para. 179).

93 ExxonMobil then brought a lawsuit against the Department of Treasury in the District Court for the Northern District of Texas (July 20, 2017), available at $<\mathrm{http}: / / \mathrm{cdn}$. exxonmobil.com/ /media/global/files/other/2017/exxonmobil-complaint.pdf $>$.

94 The sentence by the Dutch court (November 23, 2017) is available at $<$ https://uitspraken.rechtspraak.nl/inziendocument?id=ECLI:NL:RBAMS:2017:8591>.

95 "Krim-Brücke: Ermittlungen gegen niederländische Firmen," ORF (May 4, 2018), available at $<\mathrm{http}: / /$ orf.at/stories/2436740/>.

96 "Official Statement Regarding Media Allegations of a Breach by Siemens of Sanctions Against Russia," (July 2, 2015) by Siemens, available at $<$ http://sie.ag/1GN96Ce $>$.

97 "Official Statement Regarding Turbines to Crimea," (July 21, 2017) by Siemens, available at $<\mathrm{http}: / / \mathrm{sie} . \mathrm{ag} / 2 \mathrm{tPhIge}>$.

98 "Arbitration Court Denies Siemens Appeal to Return Gas Turbines Delivered to Crimea," TASS(December 14,2017), available at $<\mathrm{http}$ ://tass.com/economy/980866>.

99 Council Decision 2017/1418/CFSP (August 4, 2017).

100 This indeed appears to be a reason given by the Court for rejecting Siemens' request. Андрей Райский и Татьяна Дятел, “Суд вывел ТЭС из-под санкций ЕС," Коммерсанть (January 20, 2018), available at <www.kommersant.ru/doc/3526431>.

101 E.g., S/2018/171, cited in Chapter 9 on "North Korea: Design, Implementation, and Evasion." 
102 Ronzitti, supra note 72, p. 1.

103 See the discussions in Théodore Christakis, "Les conflits de sécession en Crimée et dans l'est de l'Ukraine et le droit international," Journal du droit international, No. 3 (2014), p. 750.

104 Conclusions of the European Council, EUCO 7/1/14 (Brussels, March 21, 2014).

105 E.g., Press release by the US Department of Treasury, "Treasury Sanctions Individuals and Entities in Connection With Russia's Occupation of Crimea and the Conflict in Ukraine," (December 20, 2016), available at <www.treasury.gov/press-center/ press-releases/Pages/j10688.aspx>.

106 Press Statement by the US Department of State, "Crimea Is Ukraine," (March 14, 2018), available at $<$ www.state.gov/r/pa/prs/ps/2018/03/279266.htm $>$.

107 Dispute Concerning Coastal State Rights in the Black Sea, Sea of Azov, and Kerch Strait (Ukraine v. the Russian Federation), PCA Case No. 2017-06.

108 Office of the Prosecutor, Report on Preliminary Examination Activities 2017, paras. 79-120. The first declaration (April 17, 2014) was made regarding the events between November 2013 and February 2014, and the second declaration (September 8, 2015) was made regarding the events since February 2014.

109 Ukraine v. Russia (no. 20958/14), Ukraine v. Russia II (no. 43800/14), Ukraine v. Russia (IV) (no. 42410/15), Ukraine v. Russia (V) (no. 8019/16), and Ukraine v. Russia (VI) (no. 70856/16). Ukraine v. Russia (III) was withdrawn by Ukraine in 2015.

110 Application of the International Convention for the Suppression of the Financing of Terrorism and of the International Convention on the Elimination of All Forms of Racial Discrimination (Ukraine v. Russian Federation), Provisional Measures (April 17, 2017). At the time of the writing, in June 2019, the ICJ was deliberating on the Russian preliminary objections. 


\section{Index}

Note: Page numbers in bold indicate a table on the corresponding page.

Afghanistan: EU restrictive measures on 119; military intervention after $9 / 1130$, 36n61; Soviet invasion of $88-89$; UN economic sanctions on $87-88$

African Union (AU) 3

Ahmadinejad, Mahmoud 182, 184, 188, 193

Albania 67

Al-Jedda case 9, 22n42, 22n47

Al-Qaeda 35n49, 38n83, 141

Anglo-Iranian Oil Co. case 25, 88

Annan, Kofi 48

Antung-Mukden Railway 84

Argentina 89, 117

arms embargo: on China after Tiananmen

117; by the EU 131; implementation of

121, 124-125; on Iran 184, 189-191;

by Japan 142; on Libya 142; on North

Korea 159-161, 169; in sanctions

reform 31, 180; on Syria 204, 217n10;

by the UN 22n51, 142, 159-161,

169, 184, 189-191; unintended

consequences of 87, 91n36; on

Yugoslavia 22n51

Arms Export Control Act (AECA) 99

Articles on State Responsibility (ASR) 8, 12; human rights and 54; International Law Commission (ILC) Commentary on $12-17,23 n 54,210,232,241 n 77$; on third-party countermeasures 14-18, 23n $54,69,210,232$

asset freeze measures 148 ; by the EU 103; against Iranians 183-185, 193; by Japan 140, 142-144, 146-148, 159, 230; against North Koreans 146-148, 159; against Russians 129-130, 226-228, 230; in sanctions reform 180; against
Syrians 202-204; by the US 101-102, 226-227; against Yemenis 140 asset recovery 119 autonomous sanctions $3-5,10-14$; beginning of 117; definition of 10-11; legal justification of 11-14; on North Korea 163-167; on Russia 223-243; on Syria 200-222, 201, 202, 205, 206, 211, 212, 213; see also Japan; United States sanctions

ballistic missiles: Iranian missile program 127, 184, 190-191, 195; North Korean missile program $128,136-137$, 145-146, 157-159, 162, 175n31

Banco Delta Asia 102

banking and financial institutions: BNP Paribas 70, 105, 126, 186; China's Bank of Dandong 164-165; customs unions 117, 240n51, 241n68; EU blocking regulations $69-70,72-73,126$, 128-129, 202-203, 226; insurance 65, $110,127,187$; investment agreements 7, 21n35; Iran and 66, 69-70, 105, 110, 186, 187; Japanese sanctions and 147; money laundering 73, 102, 164-165; North Korea and 161, 164-165, 170-171; right to development and 45; Russia and 111, 226-230; Society for Worldwide Interbank Financial Telecommunication (SWIFT) 58n56, 63, 70, 72, 127, 187; Specially Designated Nationals (SDN List) 66, 102; Syria and 202-203; US sanctions and 66, 102, 104-105, 110-111, 186, 187; see also asset freeze measures

Barcelona Traction case 15, 68, 77n52, 85 
"Basic Principles on the Use of Restrictive Measures (Sanctions)" 5

Belarus 119, 119, 240n51, 241n68

Belgium see Society for Worldwide Interbank Financial Telecommunication (SWIFT)

Benelux Economic Union 21n33

Bianchi, Andrea 67-68

bin Laden, Osama 45n48

biological weapons 18-30, 205, 207, $218 \mathrm{n} 25$

BNP Paribas 70, 105, 126, 186

Bolton, John 104, 108-109

Bonn/Berlin process 31, 180, 192

Bosnia and Herzegovina 30, 91n36, 119

Boutros Ghali, Boutros 32

boycotts 121 ; early practice of $83-85$; of Israel 88 ; private calls for 84 ; secondary vs. primary 64; Soviet boycott of the UNSC 36; of US anti-Chinese policy 84

BP shipping 187

Brazil 184

Brezhnev, Leonid 88

Burma/Myanmar 66, 99, 118, 119, 175n31

Burundi 58n56, 119

Bush, George W. 104, 106, 108, 110

Canada 62, 65, 95; Justice for Victims of Corrupt Foreign Officials Act 228; relations with British 95; sanctions on North Korea 163, 168; sanctions on Russia 227, 228, 233; sanctions on Syria 200, 203-204, 206, 208, 210-216, 221n81; Special Economic Measures Act 203-204, 228

Cardin, Ben 107

"catch-all" clause 184-185

ceasefire 130, 225, 238n19

Central African Republic (CAR) 119, 119

Central Intelligence Agency (CIA) 88

Centre D'Etudes et de Recherches Scientifiques (CERS) 205-206, 207-208, 218n25

CFSP see Common Foreign and Security Policy (CFSP)

chemical weapons 28-30; sarin 200, 206-209, 214-215, 219n50; see also Syria

Chemical Weapons Convention (CWC) 204-205, 207, 209

China: arms embargo on 117, 119; Bank of Dandong 164-164; boycotts of US anti-Chinese policy 84 ; investment agreements $21 \mathrm{n} 35$; Iran policy 110 , 196; Japan and 84, 138; Korean War 96; North Korea and 128, 159-165, 169-173, 174n22, 174n24, 176n52; opposition to sanctions 17, 55n6, 70; in the Six-Party talks 128; UN membership 36n54; US policy under Trump $168-169$; use of the veto in the UNSC 200, 204, 215

civilians: impact of sanctions on 3,25 , 30-33, 42, 46-48, 56n21, 57n45; involvement in nuclear programs 121, $127,163,218 \mathrm{n} 25$

Clinton, Bill 108

Clinton, Hillary 103-104

COCOM (Coordinating Committee for Multilateral Export Control) 138

Cohn, Gary 195

Cold War: dormancy of UN sanctions during 25, 27, 30, 88; end of the 3, 93, 97-98, 118-119, 119; EU sanctions during 117-118; Japanese sanctions during 138-139; US sanctions during 96-97; see also Cuba; North Korea

COMECON 88

Committee of Permanent Representatives (COREPER) 122-123

Committee on Economic, Social and Cultural Rights (CESCR) 43-47, 52-53, 60n99

Common Foreign and Security Policy (CFSP) 49-50, 67, 118, 120-122, 202-203, 217n10

Comoros 119

Comprehensive Iran Sanctions, Accountability, and Divestment Act of 2010 (CISADA) 4, 65, 69-70, 105

Congo, Democratic Republic of 119

Continental Tire and Rubber Co (GB) Ltd 84 control theory 68

Convention on the Rights of the Child 42

Council of Ministers 122-124

Countering America's Adversaries Through Sanctions Act (CAATSA) 65, 100, 107, 111, 227

countermeasures 8, 18; EU Blocking Regulation as 62-64, 69, 73; general theory of 11-14; lawful vs. unlawful 11; by non-injured States 14-17; retorsion vs. $16-17,63,208,210,239$ n28; by Russia 27, 232

counterterrorism 97; in Japan 141-142, 146-148; UN sanctions related to 
136-137, 141-144, 148-149; UNSC resolutions related to $35 \mathrm{n} 49,141,143$, 146; see also terrorism

CPA see EU-Russia Cooperation and Partnership Agreement (CPA)

Crimea 27, 32-33, 125-126, 129-130; autonomous sanctions and 223-243; bridge connecting Russia with 125 ; implementation of sanctions on Russia for 111, 224; Kerch Bridge 237n2; "Minsk" talks 130, 225-227, 236; see also Russia; Ukraine

Crosby v. National Foreign Trade Council (NFTC) 99

Cuba 3, 62, 64-66, 68-69, 88-89; lobbying and US policy towards 107-109; Organization of American States sanctions on 89; right to food, housing, and medicine 46; US policy under Trump 108-109; violations of sanctions against 66

customary law 5-9; Articles on State Responsibility (ASR) and 23n54; bilateral obligations and 12-13; extraterritoriality and 52, 68-69; human rights obligations and 39,52 ; nonintervention 41, 62, 68-70, 231; prior treaty provisions and 5-6, 20n 23 , 20n28, 20n29, 39; question of standing $12,17,51,232$; role of practice in creating 22n41; of the UN 8, 20n29; see also extraterritoriality; obligations customs unions 117, 240n51, 241n68 CWC see Chemical Weapons Convention (CWC)

Da'esh see Islamic State in Iraq and the Levant (ISIL)

Darfur 192

Defending Elections from Threats by Establishing Redlines (DETER) Act 111 Defense Industry Organization (DIO) 183 democracy; democratization after the Cold War 97; in Iran 194; oversight over counterterrorism 143-144; promotion of 118-119, 119, 130-131; threats to democratic legitimacy 28

"Desert Storm" 29

disarmament treaties 13-14, 16, 18

Dispute Settlement Body (DSB) 11

Dispute Settlement Understanding (DSU) 11

Dombrovskis, Valdis 72

Dominican Republic 89
Donetsk region 129, 224-225

DPRK (Democratic People's Republic of Korea) see North Korea

DRC (Democratic Republic of the Congo) 119

DSU see Dispute Settlement

Understanding (DSU)

dual-use goods 105, 121; for Iran 182, 184-185, 193; for North Korea 128, 158-159; for Russia 124, 130, 229-230; for Syria 204

E3+3 States 3, 127

"economic force" 41

Egypt; assassination attempt on Anwar Sadat 36n66; EU restrictive measures on 119; Suez Crisis 96-97

Eisenhower, Dwight 108

Embargo Act of 1807 84, 94, 112

embargo: selective 29, 31; total 29-30, 35n44; see also arms embargo; sanctions

erga omnes partes obligations $15-18,68$, 231-232

Ethiopia 86, 95, 196

E3+3 178; see also E3+3 States

European Coal and Steel Community (ECSC) treaty $2 \ln 33$

European Convention on Human Rights 9,237

European Council 92n45, 122, 124

European Court of Human Rights 22n42, 53

European Court of Justice (ECJ) 27, 49-51, 59n79, 92n45

European Economic Area (EEA) 67

European Economic Community (EEC) $2 \ln 33,89,117$

European External Action Service (EEAS) 123

European Policy Co-ordination (EPC) 117

European Political Co-operation (EPC) 117

European Union: actors 122-125; Blocking Regulation as response to US extraterritoriality 62-64, 69, 73; cases brought against by non-Member State 59n86; Committee of Permanent Representatives (COREPER) 122-123; Common Foreign and Security Policy (CFSP) 49; community judicature 58n78; Council of Ministers 122-124; current legal and administrative system 
120-125; European Commission 123-124; European External Action Service (EEAS) 123; EU-Russia Cooperation and Partnership Agreement (CPA) 233-234, 242n92; extraterritorial effects of restrictive measures 66-67; General Court of the 49-50; integration process 124; legal framework for sanctions 120-126; Maastricht Treaty 116-118, 122, 130; Member States 124-125; on secondary sanctions 92n50; Rome Treaty 117-118, 121, 124; Schengen Treaty 124; Switzerland and the 59n86, 221n70; Treaty on the Functioning of the European Union (TFEU) 4-5, 30, 50-51, 69, 89, 120-121, 124-125

European Union sanctions 49-51, 59n85; arms embargo by 131; asset freeze measures 103; on banking and financial institutions 69-70, 72-73, 126, 128-129, 202-203, 226; blocking regulations $62,69,72-73,78 \mathrm{n} 82$; after the Cold War 118-119, 119; before the Cold War 117-118, 119; effectiveness of 72-73; extraterritorial effects of 66-67; fines 125; history of 117-119, 119; implementation of 116-135, 119; on insurance services 127,187 ; on Iran 126-128, 187-188, 186; judicial review of 49-50; on North Korea 128-129; penalties for 125-126; reforms in 49-51; on Russia 27, 129-130, 226, 239n28; on Syria 119, 202-203, 202; use of the term "restrictive measure" 4-5; weapons of mass destruction (WMDs) and 118, 119

evasion: by Iran 185, 192; by North Korea 38n84, 111, 169-172; by Russia 224, 234-236; sanctions reform and 181, 192

Executive Office of the President (EOP) 101

executive orders (EOs): in Japan 139-141; on Syria 200-202, 201, 202; in the US 100-101, 193

Export Administration Act of 197999

Export Trade Control Order 138, 140 extradition 36n66

extraterritoriality: customary law and 52, 68-69; effects of sanctions 39, 66-67; EU Blocking Regulation vs US sanctions 62-64, 69, 73; of human rights obligations $40,48-49,52$; legality of extraterritorial sanctions 62-79; obligations and 51-54; of sanctions 51-54; of secondary sanctions 98,108 ; of UN Optional Protocols 48-49; of US sanctions 63-66

ExxonMobil 105, 234, 242n93

Fact-Finding Mission (FFM) 209, 215, $219 n 43$

Falklands War 89

Federal Register Process 107

Federal Republic of Yugoslavia (FRY) see Yugoslavia

Financial Action Task Force (FATF) 66, 104, 141, 149, 185

Financial Crimes Enforcement Network (FINCEN) 101-102

fines: for breaching EU sanctions 125; for breaching Japanese sanctions 139, 144; for breaching US sanctions 66, 70, 102, 104-105

Foreign Affairs Configuration (FAC) 122

Foreign Assistance Act 99

Former Yugoslav Republic of Macedonia (FYROM) 119

France: banks breaching sanctions 66, 70, 105; Iran policy 73, 181-182; Napoleonic Wars 84, 94; Russia policy 130; sanctions during Suez Crisis 96-97; sanctions during World War I 84; Syria policy 204, 215-216, 219n50

Friendly Relations Declaration of 1970 20n23, 41, 44

"frozen war" 111, 225, 238n25

FRY (Federal Republic of Yugoslavia) see Yugoslavia

Gallatin, Albert 94

Gaza Strip 46

General Agreement on Tariffs and Trade (GATT) 21n33, 64, 68, 233-234, 242n81, 242n82

General Agreement on Trade in Services (GATS) 64

General System of Preference (GSP) 118

Geneva Conventions 42

Germany: assets from Nazi occupation 96; Bonn/Berlin process 31, 180, 192; fines for breaching EU export regulations 125-126; investment agreements 21n35; on Russia and Ukraine 130, 234; sanctions on during World War I 84-85; 
Siemens case 125-126, 226, 234-235; trade with Iran 73

Gibraltar 78n82

Gowlland-Debbas, Vera 22n39

Greece 7, 196

"Green Movement" 184, 188, 194

Group of 7765

Guinea (Conakry) 119

Guinea-Bissau 119

Haiti 22n51, 89

Helms-Burton Act 64-65, 68, 72, 98, 108-109

High Representative of the Union for Foreign Affairs and Security Policy (HR) 120, 189

high seas 7, 145, 185, 237

Hollande, François 70, 130

Hong Kong 170

Houthis 195

\section{HSBC 126, 186}

human rights: customary law and human rights obligations 39,52 ; economic sanctions 43-61; effect of sanctions on 39-48; extraterritorial obligations of States 40 ; international humanitarian law 42-43; medical care 45-47, 53, $56 \mathrm{n} 21,73$; norms and instruments of $40-43$; right to development 45 ; right to education 47; right to food 45-46, $56 \mathrm{n} 21,57 \mathrm{n} 45$; right to health $45-47,53$, $56 \mathrm{n} 21,73$; right to life $43-44,56 \mathrm{n} 28$; right to self-determination 28,44 ; in the UN Charter 41-42

Human Rights Council 39-40, 45-47, 49

Hussein, Saddam 87, 109, 179

Idlib Governorate 209

ILC see International Law Commission (ILC)

ILSA see Iran and Libya Sanctions Act (ISLA)

Immigrant Control and Refugee Recognition Act 141

Immigration and Nationality Act (INA) 99

India 55n6, 161, 194, 196, 207

Indonesia 119, 183

"Instrument in Support of Trade Exchanges" (INSTEX) 73, 127

insurance $65,110,127,187$

Interlaken process $30-31,180,192$

International Atomic Energy Agency (IAEA) 70, 127; Additional Protocol (AP) of
182, 189-191; in Iran 137, 179, 182, 184, 188-191, 195; in North Korea 137

International Committee of the Red Cross (ICRC) 57n 45, 225, 238n12

International Convention on the Elimination of All Forms of Racial Discrimination 42

International Court of Justice (ICJ) 25; advisory opinion on Namibia and South Africa 21n31; Barcelona Traction case $15,68,77 \mathrm{n} 52,85$; Iran's claim to the $23 n 71,44,47,71-72,83$; opinion on judicial review $34 \mathrm{n} 16$; ruling on Ukraine v. Russia 243n110; UNSC role in enforcing decisions of 25

International Covenant on Civil and Political Rights (ICCPR) 44, 48, 56n28

International Covenant on Economic, Social and Cultural Rights (ICESCR) 40, 44-46, 48, 52-53, 60n94

International Criminal Court (ICC) 237

International Criminal Tribunal for the former Yugoslavia (ICTY) 119, 199t

International Emergency Economic Powers Act (IEEPA) 99-100, 106, 201-202, 201, 202, 227

international humanitarian law 39, 42-43 see also customary law

International Law Commission (ILC) 8, 12, 41; commentary on the Articles on State Responsibility (ASR) 12-17, 23n54, 210, 232, 241n77; on the Draft Code of Offences against the Peace and Security of Mankind 41; see also Articles on State Responsibility (ASR) Intesasanpaolo 126

investment agreements $7,21 \mathrm{n} 35$

Iran: arms embargo on 184, 189-191; asset freeze measures 183-185, 193; ballistic missile program 127,184 , 190-191, 195; banking and financial institutions 66, 69-70, 105, 110, 186, 187; Bonn/Berlin process and 180; "catch-all" clause 184-185; China and 110,196; claim against the US in the ICJ 23n71, 44, 4723n71, 44, 47, 71-72, 83; coordination among major powers 192-195; democracy in 194; dual-use goods 182, 184-185, 193; EU restrictive measures on 119; explanation for change in policy 192-195; France and 73, 181-182; goods and cargo bound for 178, 185; "Green Movement" 
184, 188, 194; Interlaken process and 180; International Atomic Energy Agency (IAEA) in 137, 179, 182, 184, 188-191, 195; Islamic Revolutionary Guard Corps (IRGC) 183; legitimacy of UN sanctions on 178-181; missile restrictions 190-191; nature of the regime 194-195; nuclear negotiations and 188-192; outline of UN sanctions on 181-185; right to healthcare in $58 \mathrm{n} 56$; sanctions evasion by 185,192 ; "snap back" procedure 70, 127, 190-191; Stockholm process and 180181; sunset clauses 191-192; trade with Germany 73; travel bans on 126-127, 183; Treaty of Amity, Economic Relations, and Consular Rights (Iran-US) 23n71, 44, 47, 71-72, 83; unilateral sanctions on 185-188, 186; UNSC resolutions related to 69-70, 127, 182-185; US policy under Obama 69-70, 188, 194-195; US policy under Trump 62, 70-73, 110-111, 127, 178, 190-191, 195-196; US sanctions on 109-111, 185-187, 186; violations of US sanctions against 66; weapons of mass destruction (WMDs) and 179, 185; see also Joint Comprehensive Plan of Action (JCPOA)

Iran and Libya Sanctions Act (ILSA) 64, 98, 105-106

Iran Nuclear Agreement Review Act (INARA) 100

Iraq: Al-Jedda case 9, 22n42, 22n47; comprehensive trade sanctions on 3 ; invasion of Kuwait 3, 27, 29-32, 109, 179; "oil-for-food" program 32, 109 , 179; petroleum products from $37 \mathrm{n} 78$; UN multinational force in $9,22 \mathrm{n} 44$; UNSC resolutions related to $37 \mathrm{n} 78,179$; US sanctions on 4, 109; weapons of mass destruction (WMDs) and 109-110

Islamic Revolutionary Guard Corps (IRGC) 183

Islamic State in Iraq and the Levant (ISIL) $35 n 49,141$

Israel 88, 96-97, 194-195

Italy 86, 95, 196

Ivory Coast 119, 119

Japan: 2014 Counter-Terrorism Act 147; agencies that implement sanctions 142-144; arms embargo by 142; asset freeze measures 140, 142-144, 146-148, 159, 230; banking and financial institutions 147; China and 84,138 ; cooperative and proactive approach to 136-139; counterterrorism 141-142, 146-148; due process concerns and sanctions 146-148; executive orders in 139-141; fines for breaches sanctions 139 , 144; Foreign Exchange and Foreign Trade Act (FEFT Act) 137-141, 150n28, 150n34, 151n36, 151n43, 151n44, 202; Immigration Control and Refugee Recognition Act141; implementation of sanctions 136-154; investment agreements $21 \mathrm{n} 35$; legal and administrative framework 139-144; Minister of International Trade and Industry (MITI) 138-160; Ministry of Finance (MOF) 142-143; National Public Safety Commission 148; penalties 144; sanctions on North Korea 145-146; sanctions on Syria 203; in the Six-Party talks 128; statutory basis for sanctions 139-141; travel bans by 140,142

Jefferson, Thomas 84, 94

Joint Comprehensive Plan of Action (JCPOA) 3, 93, 100, 126-128, 178; legality of reimposing sanctions based on 70-73; UNSC resolutions on 189-192, 194-195; US withdrawal from $62,110,127,178,195-196$

Joint Investigative Mechanism (JIM) 204, 209, 215

judicial review 34n16, 39-40, 49-50, 54

Kadi judgement 50, 59n78, 88-89, 92n45, 121-122, 146-148

Kazakhstan 217n20, 240n51, 241n68

Kennedy, John F. 108

Kerry, John 188-189

Khamenei, Ayatollah 188

Khan Shaykhun 209, 221n81

Khan, A.Q. 181

Khatam-al-Ambiya (KAA) 183

Khatami, Mohammad 181-182

Kim Jong Un 128, 157-160, 172-173

Korea see North Korea; South Korea

Korean War 30, 96, 164

Kosovo 30, 33, 130

Kreutz, Joakim 117

Krisch, Nico 6

Kuwait 3, 27, 29-32, 109, 179 
Latin America 96

Lauterpacht, Sir Elihu 91n36

League of Nations 24, 85; Article 16 of the Covenant 26, 85-86, 95

lex posterior rule 6

lex specialis rule 6

Liberia 35n46, 119

Libya: arms embargo on 142; EU restrictive measures on $117,119, \mathbf{1 1 9}$; Iran and Libya Sanctions Act (ILSA) 64, 98, 105-106; sanctions on $62,69,98$, 105-106

Lisbon Treaty 120

Lloyd's 187

Lockerbie 20n19

"London Report" 117

Luhansk 224

Maastricht Treaty 116-118, 122, 130

Magnistsky, Sergei 99

Malawi 37n75

Malaysian Airlines flight 17 (MH 17) 130, 225,230

Manchurian Incident 84, 86, 95

Mansudae Overseas Group of Companies 170, 176n53

Massachusetts's sanctions against Myanmar 99

McMaster, H.R. 195

medical care 45-47, 53, 56n21, 73

Merkel, Angela 130

MI6 88

"Minsk" talks 130, 225-227, 236

Mojahedin-e Khalq (MEK) 181

Momtaz, Jamshid 71

money laundering 73, 102, 164-165

Montenegro 30, 67

Mossadegh, Mohammad 88

Mozambique 37n75

MTCR (Missile Technology Control Regime) 184

multinational force $9,22 \mathrm{n} 44$

Munich-Re 187

Mussolini, Benito 86

Myanmar 66, 99, 118, 119, 175n31

Namibia $2 \ln 31,170$

Napoleonic Wars 84, 94

National Emergencies Act (NEA) 201, 227

National Security Council (NSC) 101, 103

Netherlands 21n33, 125, 225

NFTC see Crosby v. National Foreign Trade Council (NFTC)
Nicaragua 88-89

Nigeria 119

Nikkoten case 138

Nodong-1 137

Non-Aligned Movement (NAM) 55n5, 65

Non-Importation Acts 84, 94

Non-Intercourse Act of 1809 84, 95

nonintervention 41, 62, 68-70, 231

nonproliferation 28-29, 119, 181;

disarmament treaties 13-14, 16, 18; see also nuclear weapons; weapons of mass destruction (WMDs)

Non-Proliferation Treaty (NPT) 19n13; North Korea's withdrawal from 137; Six-Party talks 128, 159; see also International Atomic Energy Agency (IAEA)

North Korea 157-177; arms embargo on 159-161, 169; asset freeze measures 146-148, 159; autonomous sanctions on 163-167; ballistic missile program 128, 136-137, 145-146, 157-159, $162,175 \mathrm{n} 31$; banking and financial institutions 161, 164-165, 170-171; Canadian sanctions on North Korea 163, 168; China and 128, 159-165, 169-173, 174n22, 174n24, 176n52; dual-use goods 128, 158-159; gaps in implementing sanctions on $175 \mathrm{n} 30$; goods and cargo bound for 145 , $174 \mathrm{n} 28$; implementation of sanctions on 167-169; International Atomic Energy Agency (IAEA) in 137; "Leap Day Deal" with the US 159-160; missile program 128, 136-137, 145-146, 157-159, 162, 175n31; multilateral sanctions regime today 162 ; Namibia and 170; nuclear tests 19n13, 128-129, 145-146, 148, 157-162; sanctions evasion by $38 \mathrm{n} 84,111,169-172$; SixParty talks on the NPT 128, 159; Sony Pictures hack 160, 165; trade with Myanmar 175n31; travel bans on 158-159, 164; Trump-Kim talks 128, 157-160, 172-173; United Nations sanctions on $38 \mathrm{n} 84,158-163$; UNSC resolutions related to $35 \mathrm{n} 47$, 128-129, 144-146; US policy under Obama 110-111, 160, 164, 175n31; US policy under Trump 128, 157-160, 164-166, 172-173; US sanctions on 109-111, 164-167; weapons of mass destruction 
(WMDs) and 145-146; see also Non-Proliferation Treaty (NPT) Norway 67, 96

NSG (Nuclear Suppliers Group) 182, 184-185

nuclear weapons: ballistic missiles 127-128, 136-137, 145-146, 157-159, 162; civilian involvement in nuclear programs $121,127,163,218 \mathrm{n} 25$; disarmament 30; Iranian ballistic missile program 127, 184, 190-191, 195; North Korean ballistic missile program 128, 136-137, 145-146, 157-159, 162, 175n31; "procurement channel" 185, 191-192; tests 19n13, 128-129, 145-146, 148, 157-162; uranium enrichment 110, 182, 195; see also Iran; Non-Proliferation Treaty (NPT); North Korea nuclear-free zone treaty 13,16

Obama, Barack: delegation of authority under 104; Iran policy 69-70, 188, 194-195; North Korea policy 110-111, 160, 164, 175n31; problems with Congress 70; Syria policy 215 obligations 5-18, 51-53; bilateral 12-15, 232; collective 12-13, 15; as defined by the International Covenant on Economic, Social and Cultural Rights (ICESCR) 60n94; as distinct from rights 19n18; erga omnes partes $15-18,68$, 231-232; extraterritorial 51-54; human rights 40, 52-53; interdependent 13-18, 63; nature of breaches of 15-16, 231-232; positive 43, 51, 56n 28

OFAC see Office of Foreign Asset Control (OFAC) under US Department of the Treasury

Office of Foreign Assets Control (OFAC) 66, 76n $34,96,101,104-105,126,131$, $165,186,200-201$

Office of Foreign Funds Control (FFC) 96 "oil-for-food" program 32, 109, 179

OPCW see Organisation for the Prohibition of Chemical Weapons (OPCW)

Organisation for the Prohibition of Chemical Weapons (OPCW) 203-204, 209, 214-215; Fact-Finding Mission (FFM) 209, 215, 219n43; Joint Investigative Mechanism (JIM) 204, 209, 215

Organization of American States 89
P5+1 178, 188-190, 195-196

Park Geun-hye 166

peace $3-5,7-9,19 \mathrm{n} 10,19 \mathrm{n} 13$; beyond the absence of armed conflict 28; concept of a "breach of" 28 ; defining "aggression" $28,35 \mathrm{n} 27$; "threat to the peace" $4-5$, 19n10, 24-25, 28-29, 32, 86

Pericles 83

PNB Paribas 66

Poland 64, 233

Political and Security Committee (PSC) 122

Pompeo, Mike 65, 195

Poroshenko, Petro 130

Portugal $37 \mathrm{n} 75$

prior consent 11, 18

"procurement channel" 185, 191-192

Putin, Vladimir 111, 130

Qatar 42

question of standing $12,17,51,232$

RELEX see Working Party of Foreign

Relations Counsellors (RELEX)

retorsion 16-17, 63, 208, 210, 239n28

Rice, Susan 104

Rome Statute 237

Rosneft 233-234, 242n92

Rouhani, Hassan 127, 188, 193-194

Royal Bank of Scotland 126

Rubio, Marco 108

Russia 223-243; asset freeze measures 129-130, 226-228, 230; Australian sanctions on 228-229; banking and financial institutions 111, 226-230; Belarus and 240n51, 241n68; boycott of the Security Council 36n54; Canadian sanctions on Russia 227, 228, 233; countermeasures by 27, 232; in customs unions 240n51, 241n68; dual-use goods and 124, 130, 229-230; effectiveness of sanctions on 234-236; EU sanctions on 119, 225-227; EU-Russia Cooperation and Partnership Agreement (CPA) 233-234, 242n92; evasion of sanctions by 224, 234-236; Federal Laws in response to trade restrictions 233; France and 130; Germany and 130, 234; Japan and 230; legality of sanctions on 231-234; New Zealand and 231; nonrecognition of sanctions 235; opposition to sanctions 55n6; presence in Eastern Ukraine 224-225; reasons for sanctions on 224-225; Russian 
perspective on sanctions 232-234; sanctions as response to breach of obligations erga omnes partes 231-232; in the Six-Party talks 128; spectrum of sanctions on 225-231; Switzerland and 229-230; travel bans on 129-130, 226-231, 242n86; US sanctions on 27, 64, 88, 111, 227-228; see also Crimea; Ukraine

\section{Sadat, Anwar 36n66}

sanctions: administrative 25, 144; autonomous 3-5; "chilling effect" of 66; comprehensive vs. targeted 3; definition of 3-5; due diligence and risk mitigation 66, 76n34, 167; economic sanctions in the UN 86-88; economic sanctions outside the UN 88-89; extraterritorial obligations and 51-54; history of implementation 82-92; human rights implications of 39-61; impact on civilians $3,25,30-33,42$, 46-48, 56n $21,57 \mathrm{n} 45$; in the interwar period $84-86$; legality of extraterritorial 62-79; on nonstate entities 29; potential humanitarian consequences of the sanction on the aviation $37 \mathrm{n} 80$; primary 63-64, 67-69, 97-98, 104-105, 189; primary vs. secondary $67-70,104$; prior consent and 11, 18; responsibility invoked by third parties $14-15$; secondary 62-69, 72-73, 89-90, 97-97 104-105, 186-187, 186, 189, 193-194; selective financial sanctions on banks 19n5 19; "smart" 33, 48, 87, 180, 192; Stockholm process $31,180-181,192$; stricto sensu 4, 8; targeted 3, 30-31, 40, $48,116,130-131$; on "terrinational" grounds 69; transatlantic divide on legality of secondary sanctions 67-70; since the UN Charter 86-89; UN-defined measures $35 \mathrm{n} 43$; voluntary disclosure and 125-126; before World War I 83-84; see also autonomous sanctions; European Union sanctions; extraterritoriality; United Nations sanctions; United States sanctions "sanctions decade" of the 1990s 3, 86 Sarajevo $91 \mathrm{n} 36$ sarin 200, 206-209, 214-215, 219n50

Schengen Treaty 124

secondary boycotts 64 selective embargo 29, 31 self-defense $30,36 \mathrm{n} 61$

self-determination 28,44

September 11 36n61, 98, 101, 116, 121, 130,146

Serbia $30,67,91 \mathrm{n} 36$

Shanghai Chamber of Commerce 84

Siemens 125-126, 226, 234-235

Singapore: North Korea and 165, 167, 170; Trump-Kim talks in 111, 128, 172

Single European Act (SEA) 117-118

Sino-Japanese Treaty of 191584

Six-Party talks 128,159

"smart sanctions" 33, 48, 87, 180, 192

"snap back" procedure 70, 127, 190-191

Society for Worldwide Interbank Financial Telecommunication (SWIFT) 58n56, 63, $70,72,127,187$

Somalia $38 \mathrm{n} 82,86$

South Africa 86, 97, 117, 161; Apartheid government 97, 192; Dutch refusal to act against $21 \mathrm{n} 33$; Namibia and $2 \ln 31$

South Korea 166-168, 171-173; Korean War 30, 96, 164; policy alignment with other powers 166-168, 194-196; in the Six-Party talks 128 ; unilateralism by 157-158, 163

South Sudan 118, 119

Southern Rhodesia 7, 29, 31-32, 35n44, $37 \mathrm{n} 75,86,117$

Soviet Union see Russia

Specially Designated Nationals (SDN List) 66, 102

State Secretariat for Economic Affairs (SECO) 202

States: injured State 12-18, 210, 238; legal liabilities of 7-8, 21; see also customary law; extraterritoriality; obligations

Stockholm process 31, 180-181, 192

Sudan 32; Darfur 192; EU restrictive measures on 119; sanction on aviation in $37 \mathrm{n} 80,38 \mathrm{n} 81$; violations of US sanctions against 66

Suez Crisis 96-97

SWIFT see Society for Worldwide Interbank Financial Telecommunication (SWIFT)

Switzerland 202; the EU and 59n86, 221n70; Interlaken process 30-31, 180, 192; sanctions on Russia 229-230; sanctions on Syria 203, 206, 208-218

Syria 200-222, 205-206, 211, 212, 213; arms embargo on 204, 217n10; asset freeze measures against 202-204; 
banking and financial institutions 202-203; Canadian sanctions on 200, 203-204, 206, 208, 210-216, 221n81; Damascus 208, 218n25; dual-use goods 204; EU sanctions on 119, 202-203, 202; France and 204, 215-216, 219n50; goods and cargo bound for 204, 207, 226; Japanese sanctions on 203; Switzerland and 203, 206, 208-218; travel bans on 202-204; UN sanctions on 204-205, 205-206; UNSC resolutions related to $188-196,204$, 214; US policy under Obama 215; US policy under Trump 209-210, 214-215; US sanctions on 200-202, 201; weapons of mass destruction (WMDs) and 202, 202, 207-208, 213-214; see also Organisation for the Prohibition of Chemical Weapons (OPCW-UN)

Syria Accountability and Lebanese Sovereignty Act of 2003 (SAA) 201

Syrian Scientific Studies and Research Centre (SSRC) 205-206, 207-211, 214-216, 218n25, 221n80, 222n86

Tabibi, Abdul Hakim 41

Taiwan 36n54, 196

Taliban 36n61, 141

Talmon, Stefan $21 \mathrm{n} 38$

Tatsu-Maru Affair 84

terrorism: Al-Qaeda 35n49, 38n83, 141;

EU restrictive measures 119; Islamic

State in Iraq and the Levant (ISIL) 35n49, 141; September 11 36n61, 98, 101, 116, 121, 130, 146; see also counterterrorism

TFEU see Treaty on the Functioning of the European Union (TFEU)

"threat to the peace" $4-5,19 \mathrm{n} 10,24-25$, 28-29, 32, 86

Tiananmen Square 117

Tillerson, Rex 104, 195

Tokyo District Court 138-139

Toshiba 138-139

total embargo 29-30, 35n44

Townshend Acts 84

trade and commerce: exports to Iran

178, 185; exports to North Korea 145, 174n28; exports to Syria 204, 207, 226; see also banking and financial institutions; dual-use goods

Trading with the Enemy Act 84-85, 99 transatlantic dilemma 63
Transnistria 119, 119

travel bans: implementation of 107, 119, 121, 124-125, 146; on Iran 126-127, 183; Japan and 140, 142; on North Korea 158-159, 164; on Russia 129-130, 226-231, 242n86; in sanctions reform 31, 38n84, 180; on Syria 202-204

Treaty of Amity, Economic Relations, and Consular Rights (Iran-US) 23n71, 44, $47,71-72,83$

Treaty of Rome 117-118, 121, 124

Treaty on the Functioning of the European Union (TFEU) 4-5, 30, 69, 120-122, 124-125; Article 215 4-5, 89, 120-121, 202; Article 263 50-51, 59n80

Tritonia Holdings 170

Truman, Harry 96

Trump, Donald 27, 93, 106; autonomous sanctions under 175n32; China policy 168-169; Cuba policy 108-109; Iran policy $62,70-73,110-111,127,178$, 190-191, 195-196; North Korea policy 128, 157-160, 164-166, 172-173; Syria policy 209-210, 214-215

Tunisia 119, 119

Turkey 67, 184, 196

Ukraine 67, 111, 129-131, 223-237, 237n2; Donetsk region 129, 224-225; fighting corruption in 119; "frozen war" in 111, 225, 238n25; Kerch Bridge 237n2; Malaysian Airlines flight 17 (MH 17) 130, 225, 230; Russian presence in Eastern Ukraine 224-225; see also Crimea; Russia

unilateral coercive measures 17, 39-40, 42-43, 45-46, 49, 55n5, 57n45, 58n56, 63-65 see also autonomous sanctions

unilateral sanctions see autonomous sanctions

United Kingdom: Anglo-Iranian Oil Co. case, 25, 88; Canada and 95; Falklands War 89; Greece and 7; "lifting the corporate veil" 85; MI6 88; Suez Crisis 96-97; trade with Iran 73; UN multinational forces and 9

United Nations: administrative sanctions for noncompliance 25; arms embargo 22n51; authorizations 9; aviation sanction on Sudan 37n80, 38n81; creation of 24; definition of aggression 28, 35n27; designated individuals 205 
205; embargo on Iraq, actual effects of 47; ICJ opinion on legally binding resolutions 21; legal effect of customary law 8 ; legally binding nature of resolutions $2 \ln 31$; mandatory measures 9; nature of recommendations 6-8, 22n39; Optional Protocols 48-49; see also United Nations Charter; United Nations General Assembly (UNGA); United Nations sanctions; United Nations Security Council (UNSC)

United Nations Charter: Article 1 (aggression) 34n27; Article 103 (obligations) 5-9, 18, 19n17, 19n18, 20n23; Article 19 (payment of dues) 34n9; Article 25 (obligations) 26, 29, 71; Article 39 (responding to threats to peace) $4-5,19$ n10, 28, 178; Article 40 (provisional measures) 178-179; Article 43 (multilateral force) 36n53; Article 50 (inability to meet obligations) $37 \mathrm{n} 73$, 37n76; Article 51 (self-defense) 30-32; Article 94 (enforcement measures) 25; Articles 41 and 42 (nature of sanctions) 9, 28-29, 86-88, 204; Articles 5 and 6 (expulsion) 25, 33n7, 33n8; lack of the word "sanctions" in 4

United Nations Conference on the Law of Treaties 41

United Nations Convention on the Law of the Sea (UNCLOS) 237

United Nations General Assembly: 2030 Agenda for Sustainable Development 40; call against "unilateral coercive measures" 39; Collective Measures Committee 7-8, 22n41; on consultations $37 \mathrm{n} 74$; definition of aggression 28 , 35n27; Uniting for Peace resolution 7, $34 \mathrm{n} 12$

United Nations High Commissioner for Human Rights 45-46, 56n21

United Nations Participation Act (UNPA) 137,201

United Nations Register of Conventional Arms 184

United Nations sanctions 24-38; accompanying measures $31-32$; arms embargo 22n51, 142, 159-161, 169, 184, 189-191; Bonn/Berlin process $31,180,192$; dormancy during the Cold War 25, 27, 30, 88; on Haiti 22n51; illegal mandatory vs. nonmandatory 5-9; implementation of
27-32; Interlaken process 30-31, 180, 192; on Iran 181-185; on ISIL and Al-Qaeda 35n49; legal justification of 5-9; mechanism 24; on North Korea $35 \mathrm{n} 47,38 \mathrm{n} 84$; reform of $31,38 \mathrm{n} 84$, 48-49, 180-181, 192; related to counterterrorism 136-137, 141-144, 148-149; Security Council role in 26-27; shift in practice 87; on South Africa 21n31; Stockholm process 31, 180-181, 192; on Syria 204-205,

205-206; triggering of sanctions mechanism 26-29; typology of 29-32; see also United Nations Charter; United Nations Security Council (UNSC)

United Nations Security Council 4-11; authorization of multinational force 9, 22n44; boycott by Russia 36n54; Chapter VII of the UN Charter and 4-6, 9, 19n10, 24-32, 86-88, 178-179, 204; on extradition 36n66; Office of the Ombudsperson 27, 33, 147; practice of sanctions 8; predilection for economic sanctions 86-87; Resolution 1267 sanctions regime 141-143, 146-149; resolutions related to counterterrorism 35n49, 141, 143, 146; resolutions related to Iran $69-70,127,182-185$; resolutions related to Iraq 37n78, 179; resolutions related to North Korea 35n47, 128-129, 144-146; resolutions related to Syria 188-196, 204, 214; resolutions related to Yugoslavia 141; role in sanctions 26-27; sanctions against Liberia $35 \mathrm{n} 46$; tension between extraterritorial sanctions and competences of the $77 \mathrm{n} 48$; on unilateral coercive measures 17, 39-40, 42-43, 45-46, 49, 55n5, 57n45, 58n56, 63-65; use of the word "sanctions" by 4 ; veto 10, 27, 32-33, 36n54, 190; see also United Nations Charter

United Nations Special Rapporteur 40-42, 47,49

United States: agencies that implement sanctions 101-104; anti-Chinese policy and boycotts 84; Civil War 95; Executive Office of the President (EOP) 101; executive orders (EOs) 100-101, 193, 200-202, 201, 202; invocation of self-defense in Afghanistan 36n61; nonproliferation 202, 202; president's role in sanction 85; September 11 36n61, 98, 101, 116, 121, 130, 146; US 
Mission to the United Nations 104; see also United States Congress; United States sanctions; US Department of the Treasury; specific executive agencies United States Congress 85, 98-100; Arms Export Control Act (AECA) 99; Comprehensive Iran Sanctions, Accountability, and Divestment Act of 2010 (CISADA) 4, 65, 69-70, 105; Countering America's Adversaries Through Sanctions Act (CAATSA) 65, 100, 107, 111, 227; Defending Elections from Threats by Establishing Redlines (DETER) Act 111; Embargo Act of 1807 84, 94, 112; Export Administration Act of 1979 99; Foreign Assistance Act 99; Helms-Burton Act 64-65, 68, 72, 98, 108-109; Immigration and Nationality Act (INA) 99; International Emergency Economic Powers Act (IEEPA) 99-100, 106, 201-202, 201, 202, 227; Iran and Libya Sanctions Act (ILSA) 64, 98, 105-106; Iran Nuclear Agreement Review Act (INARA) 100; legislation authorizing sanctions 98-100; National Emergencies Act (NEA) 201, 227; Non-Importation Acts 84, 94; power to legislate foreign commerce 98-99; Syria Accountability and Lebanese Sovereignty Act of 2003 (SAA) 201; Trading with the Enemy Act 84-85, 99; United Nations Participation Act (UNPA) 137, 201; US National Defense Authorization Act (NDAA) 186, 188; USA PATRIOT Act 102

United States Constitution 98-99, 106-107

United States sanctions: asset freeze measures 101-102, 226-227; on banking and financial institutions 66 , 102, 104-105, 110-111, 186, 187; during the Cold War 96-97; since the Cold War 97-98; on Cuba 107-109; current legal and administrative system 98-106; in early history of 83-84, 94-96; enforcement of UN vs. non-UN sanctions 106-111; executive orders on 100-101, 200-202, 201; extraterritorial 63-66; fines and penalties 66, 70, 102, 104-106; implementation of 93-115; on Iran 109-111, Iran 185-187, 186; on Iraq 4, 109; on North Korea 109-111,
164; promoting policy alignment 166-167; on Russia 27, 64, 88, 111; Soviet cereal embargo 88; Soviet Pipeline Regulations 64; statutory basis for $85,98-100$; Stockholm process 31, 180-181, 192; on Syria 200-202, 201

United States Supreme Court 99

Uniting for Peace resolution (UNGA Resolution 377) 34n12

uranium enrichment 110, 182, 195

US Department of Commerce 101-103

US Department of Energy 103

US Department of Homeland Security 101, 107

US Department of Justice 66, 164-165

US Department of State 103-104, 107, 109, 161-162

US Department of the Treasury 101-102; designations and penalties 164 ; Financial Crimes Enforcement Network (FINCEN) 101-102; Office of Foreign Assets Control (OFAC) 66, 76n34, 96, 101, 104-105, 126, 131, 165, 186, 200-201; Office of Foreign Funds Control (FFC) 96; settlements paid to 186-187, 186; Specially Designated Nationals (SDN List) 66, 102

US National Defense Authorization Act (NDAA) 186, 188

USA PATRIOT Act 102

USSR see Russia

Uzbekistan 119, 119

Venezuela 93, 106, 108-109, 119

Vercingetorix 84

Versailles Peace Conference 84

Vienna Convention on Diplomatic Relations 12-13, 71

Vietnam 96

War on Terrorism see terrorism weapons of mass destruction (WMDs) 87; biological weapons 18-30, 205, 207, 218n25; chemical weapons 28-30; EU sanctions and 118, 119; in Iran 179, 185; in Iraq 109-110; in North Korea 145-146; in Syria 202, 202, 207-208, 213-214; US executive orders on 202; see also Iran; North Korea; Syria

Wilson, Woodrow 85, 87, 95

Working Party of Foreign Relations Counsellors (RELEX) 123-124 


\section{Index}

World Trade Organization (WTO) 11, 64, $68,98,233$

Yanukovych, Viktor 129

Yaoundé Convention 117

Yemen 140, 143, 195

Yugoslavia 30, 141; arms embargo on 22n51, 91n36; COMECON boycott on 88 ; EU restrictive measures on
119; International Criminal Tribunal for the former Yugoslavia (ICTY) 119, 119; Kosovo 30, 33, 130; UNSC resolutions related to 141

Zambia $37 \mathrm{n} 75$

Zarif, Javad 189, 193

Zimbabwe 45, 119, 119; see also Southern Rhodesia 